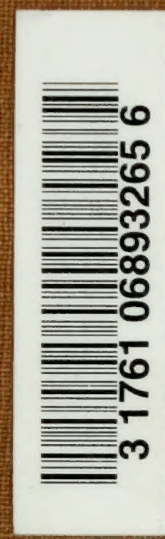

- Hustrailan..

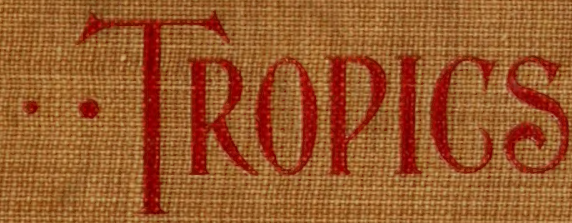

By Alfred Searcy. 
26 heloy trepancers

34) Buylalo +23 ?

10 Riper R.

112 mud hut (abo!)

in Ancerthur P

(2) Bomborla stats

Qov Vudima R

24 Doly R

2ur experme muter

Una alligutors +268

322 Wheteans 
Digitized by the Internet Archive in 2010 with funding from University of Toronto 

IN AUSTRALIAN TROPICS 



\section{In Australian Tropics}

s 


\title{
In Australian Tropics
}

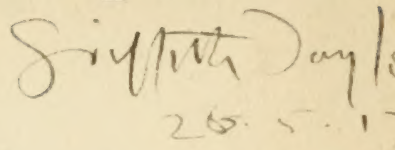

\author{
BY \\ A L F R E D S E A R Y \\ Fourteen years Sub-Collector of Customs at Port Darwin, \\ Northern Territory, and now Clerk Assistant of House of \\ Assembly, Adelaide, South Australia
}

WITH A MAP AND FIFTY-FIVE ILLUSTRATIONS

\author{
THIRD EDITION
}

GEORGE ROBERTSON \& CO (PROPRIETARY LTD.)

LONDON, MELBOURNE, SYDNEY, ADELAIDE, AND BRISB.ANE 


\section{PRINTED IN ENGLAND}

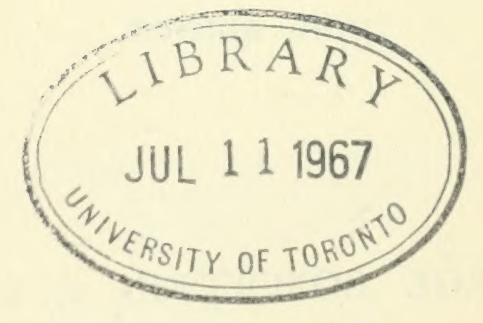




\section{PREFACE}

I THINK it was Sir IValter Besant who advised the young aspiring novelist that the great requisite for success in the field of fiction was experience. Louis Becke is a striking proof of this. When asked by Mr. Archibald, then Editor of the Sydney Bulletin, to write the stories he had been telling viva voce, the trader complained that he could not; that, in fact, he had never written anything in his life. "Write them just as you have told them,' was Archibald's advice, and the result was those delightful tales of the South Sea Islands, entitled By Reef and Palm. Even poor writers with experience at their backs are more convincing than fine writers who lack that invaluable stock-in-trade. It is only the enthusiast who has ridden over fences who knows the joy and exhilaration of hunting. It is only the man who has lived in the far-removed 'out-beyond,' who has wandered over the great plains, studied the weird scenery, watched the kangaroo bound along, the gaudy parrot flash by, has inhaled the sweet scent which the trees, the shrubs, and the grass contain, and has grown familiar with the thousand and one haunting sights, sounds, and silences which prevail, who can understand the charm and poetry of the Australian 


\section{IN AUSTRALIAN TROPICS}

Bush. And so one could go on citing innumerable similar cases.

During my fifteen years on the press any articles of mine which have lived for more than a little day have always been those written from actual experience. This is all by way of preliminary to the important fact that Mr. Alfred Searcy knows the north coast of Australia. For fourteen years he was stationed at Port Darwin as Sub-Collector of Customs, and without any attempt at fine writing, he has told the story of that novel and exciting period in his life of hard work, of his adventures by land and sea, of 'moving accidents,' and 'hairbreadth 'scapes.' Anything which Mr. Searcy has set down. if not an actual personal experience-and that is the foundation of the great portion of the book-is at least an absolute fact which can be verified. In not a single instance has Mr. Searcy done any romancing.

The following telegram from Melbourne appeared in the South Australian Register newspaper on September 9, 1904 :-

'The Malays who man the proas which sail down from Macassar to Port Bowen. in the Northern Territory, are suspected by officers of the Customs Department of smugging, and it was recently suggested that some of their number aloo obtained admission to Australia despite the Immigration Restriction $\Lambda$ After considering these representations, the Minister for Customs determined to close Port Bowen as a reporting station from January I, and make oversea $A$ siatics who wish to engage in the trepang industry go to Port Darwin. It is believed that the trade-winds will not enalie proas to go to Port Darwin, and therefore they 


\section{PREFACE}

will in all probability be prevented from visiting Northern Austialia.'

That telegram was read and re-read by Mr. Searcy, the Acting Clerk of the House of Assembly, with inten-e interest. Just over twenty years before, Mr. Searcy went along the coast, made seizures and levied fines, and arranged that the proas should report at Oojountambanoonoo in Bowen Straits, instead of Port Essingtc $n$. The Macassar proas were discovered on February 17, ISO3, in the Malay Road, south of Cotton Islands (English Company's Islands), by Captain Flinders; and on March 27,1884 , when on a cruise in search of proas which had failed to procure the necessary licences, Mr. Searcy anchored in almost the identical place where Flinders first sighted them in February ISO3, eighty-one years before. I was told off to go and interview Mr. Searcy and write an article about Malay proas. He told me of his several cruises after the men from Macassar, and the one article developed into four. Such great interest was taken in the interviews with Mr. Searcy that numerous correspondents wrote asking that the articles might be extended. I dropped down from the Hansard Gallery one night, and in the course of a smoke and a chat it was decided to continue the narratives. The succeeding articles dealt with hunting buffalo and wild cattle, justified the term 'Sportsman's Paradise' with regard to the Northern Territory of South Australia, detailed exciting experiences with alligators, recorded some of the hard work which fell to the lot of the sub-collector, told of the pioneers at the extreme outposts of civilisa- 


\section{IN AUSTRALIAN TROPICS}

tion, recalled the history of those early military settlements at Fort Dundas, on Melville Island, and Raffles Bay, and Port Essington on the mainland, recounted incidents which explained the character of the treacherous aborigines, and in many other ways delighted the reader. These articles were published in pamphlet form by the authority of the South Australian Government. That publication is but the skeleton of the present book, which is charged full of thrilling experiences from beginning to end. Both Mr. Louis Becke and Mr. Frank Bullen, those adventurous spirits of the sea, told Mr. Searcy, after reading his pamphlet, that with such abundant experiences to work on they could have knocked together a dozen books.

I write this in Mr. Searcy's den at his own private house; which by reason of the many relics of the Northern Territory which hang on the walls has a distinct atmosphere of the Orient about it. Among the curiosities are the long pods of the Queensland bean; the fruit of the baobab, as big as an emu egg, from the tree under which Gregory the explorer camped on the Victoria River woomeras from Port Essington; a photograph of Stuart's tree, framed in a piece of wood taken from a branch of the memorable landmark in connection with the historic crossing of the Australian continent; and a human skull picked up outside the police camp on Mount M'Minn. A piece of bloodstained, jagged spear from Melville Island is the memento of a tragredy. A party of whites were on the island, and a mainland black boy they had with them was speared 


\section{PREFACE}

by the wild niggers. The weapon went right into the unfortunate boy's body, and Mr. Searcy possesses the piece which was sawn off the spear close to the flesh. The victim did not live long. Two teeth, four inches long, taken from a dead alligator near Stuart's tree, give one an idea of the fearful damage the monster could have done with its jaws. Two Malay knives are relics of the Cape Brogden massacre, which Mr. Searcy fully describes. The portion of the main beam of the Flying Cloud, in which Mr. Searcy had his first cruise, and which contained the official number and the tonnage, hangs over the mantelpiece. The immense tusk of a dugong, a peculiar fish with flesh like pork, articles made from tortoise-shell and pearl-shell, curious fossiis, and several ugly weapons of the swordfish, have all a personal interest for Mr. Searcy. A number of pencilsketches by a haif-caste named Flannagan, who was executed for murder. are highly prized. Flannagan killed a man on the Victoria River over a game of cards, and he drew the sketches while he was under sentence of death. His fancy seemed to run in the direction of horses and bushmen. The sketches are remindful 0 : though they show a great improvement on, the primitive art of the earliest race. On the verandah, buffalo horns and turtle shells hang. A bit of brick from Melville Island, and made about I825, recalls the military settlements on the northern shores of Australia. But the interest of the relics is making this preface too lengthy.

Although it languishes, the Northern Territory, or ix 


\section{IN AUSTRALIAN TROPICS}

'Land of the Dawning,' as it has appropriately been called, is a wonderful country, and is destined to prove of vital importance to the Empire. Any one who wants to learn all about it can safely be recommended to read In Australian Tropics.

ERNEST WHITINGTON,

South Australian Kegister. 


\section{CONTENTS}

\section{CHAPTER I}

\section{THE NORTHERN TERRITORY}

PAGB

Annexed to South Australia-Area, etc.-Const-DescriptionAncient discovery of Australia - What might have lieen-Dutch East India Company-Early discovery of gold-Ancient cannon -Dinso and its origin . . . .

\section{CHAPTER II}

\section{WHY I WENT TO PORT DARWIN}

Trip through Barrier-Dead Chinamen-On a reef-Port DarwinImpressions

\section{CHAPTER III}

\section{FIRST VOYAGE IN THE 'FLYING CLOUD"}

Malays on the north coast-First sighted by Captain Flinders-S in cutter Flyins Cloud-Port Essington-E. O. Robinson-Leave Port Essington-Sight proa-Bowen Straits-Dredging canoes and proas - Tortoise-shell-Smoke-houses - Aborigines - Bapa Paloe-After birds-Fresh-water and mangrove swamps-More proas-Pearls-Turtle-Mount Morris Bay-Buffalo-shootingBack to Port Essington-Blacks and grog-All about buffaloPaddy Cahill-Home

\section{CHAPTER IV}

\section{SECOND VOYAGE IN THE 'FLYING CLOUD}

Vicissitures of proas-Trepanging on Melville Island-Fights between Malays and blacks-Sail for Port Essington-Strorg tides 


\section{IN AUSTRALIAN TROPICS}

- Port Essington-Trepang camp-Trepang Bay-On a reefWreck of yacht Red Gauntlet-Off reef-Hard pull to Robinson's camp-Flying Cloud-Cockroaches and rats-Old military settlement-Ducks, geese, and pigeons-Wild ponies-Roast oysters and gin-Bower birds-Rille and revolver shootingSpear-throwing - 'Fair start'-How to beat up eggs-'Corpse reviver'-Shower-bath-'Flash Poll'-Pretty Maryanagenee -Nor'-wester-Knocker Bay-Hunting wild cattle-Venomous snakes-'Him bite, you dead'-Dead snake and Malay--Billy -Turtle Point-Rock and mangrove oysters-Niggers fishing - Catch a fowl-Dugong-Strength of alligators-Sucking egg--Marine music-Christmas Day-Bowen Straits-Collecting duties from proas-Defied by Malay captain-Draw revolvers -Killing not murder-Cocker Island-Jungle fowl- 'Moyout' - Alligator River niggers-Threaten murder-DepartureGrief of niggers-Bad time-Clarence Straits-Buoys-Last of Flying Cloud

\section{CHAPTER V}

\section{CRUISE IN THE S.S. 'FLEETWING'}

Murders by Alligator River niggers-Soo Hoo Yoke, in'erpreter ana Christian-Corner in opium-S.S. Fleetwing-DepartureBoiler leaks-Sree Pas Sair-Too much black bottle-E. O. Robinson-Goulburn Islands-Proas-Fines-Getting woodMalay customs-Surgical operation-Mangrove as fuel-- Haul round Island, Liverpool River-Catching birds-Entrance Island-Find timber-Bad niggers-Macassars and bloodshed Fine camping-place-Tow-line fishing-Cadell Straits--Sharks -Suspicious niggers-Cutting timber-Careless men-Alligator - 'Boom boom'-Cadell-Knowing young buck-Situck in straits-Gale and rain-Our 'old man'-Wonderful whistlerMiserable time-Find channel-Flying-foxes not wombats'On, damn !'-Arnheim 13ay-Grave of murdered Malay skipper -Uniurveyed waters-'Bier'-'I see canoe'-Mallison Island - Bapa l'alue again-Transformation scene--Cotton IslandAnchorrin top of reef-Casuarinas and green ants-Terrible tides - Malay Road-Melville Bay, Gulf of Carpentaria-- More proas - Fines-Iikely country for gold-Cadado big captain-Steal Malay ricc-Looking-glasses-Malays kill Cadado-Siart for home-13lack women in Cadel Straits-Port Essington-IIome -Malays smuggle spirits 


\section{CHAPTER VI}

\section{VOYAGE OF THE S.S. 'PALMERSTON'}

Captain Carrington-Short commons-Good Intent-Leave Port Darwin-Bad weather-Melville Island-Oojountambanoonoo -Robinson mad-'Flash Poll' again-Dylompo, Groote Island-Roper River-Aground on a sandbank - Narrow escape -Discovery of the Roper-Young Australian - 'Hot toddy'Leichardt's Bar-Ketch Good Intent seized and crew arrested -Grog shanty-Mount M'Minn-Testing liquors-Seamen on board horses-'Hell's Gate'-Square face, cards, and Worcester sauce-Nicknames-Hard cases-Kill a bullock-'Is your breath sweet?'-Paper money-Myall nigger boy'Virtue,' Myall nigger and nanto-Nipped by a shark-Aboriginal dwelling-Game and alligators-Frogs-Fearful thunderstorms-Maria Island-Sacred spots-Pellew Group-ProasBapa Paloe again-M'Arthur IRiver-Black's camp-William M'Leod-Arrest owner of Good Intent and his wife-Seize station stores-Large mob of cattle-No grog for drovers-Pull store down and load Good Intent-Camp at M'Arthur-Surveying-Hot weather-Cattle bells-Flies, etc.-Native companions-Back blockers-Expensive shout-Silver watchesLeave M'Arthur with Good Intent in tow-Malay moneyLife threatened-Queer grog-Customs of aborigines-Malay camping places.

\section{CHAPTER VII}

\section{LAST TRIP OF THE S.S. 'ELLENGOWAN}

Customs authorities defied-Old mission steamer Ellenoowan-Bad workmanship and careless surveying-Captain MacredieEngineer Griffy-Like half-tide rock-Bad gale, steamer constantly breaking down- 'Can't make the land; all up with us'-Short of water-Selfish man-Can't go astern-Melville Bay-No water-Connection Island-Good fishing-Dig for water and cut fuel-Maria Island old coal-In Roper-Smell the bottom-Depot Leichardt's Bar-Hole in side of steamerMixed crowd-Rotten curry powder-Brumby hunters-Cattle duffers-Horse thieves-Trousers wash-Alligator not a logBarefaced robbery - 'Ragged Thirteen'- 'Paddy the Priest'Terms of endearment-Shanty-keeper-Bum-boats-Fire-stick in shanty-Delirium tremens-Great endurance-Poor old Power-'To the store'-Start again-On the rocks and sandbank-Steal a case of meat-Short commons-' Look, Bunga- 


\section{IN AUSTRALIAN TROPICS}

wah'-Great fires-Maria Island again and more coal-humping -In the M'Arthur River-Lost in Batten's Creek- 'Boroloola, trrrr'-Heavy dews-Hungry- 'I see schooner'- Seize schooner-Malarial fever-Woman dies-Settlement in state of chaos-Unspeakable crimes-Salt down beef-Release schooner on payment of fines-Start for steamer-Lost in mangrove creeks-Alligators-Bad night-Want oil-See black fish-Luck turns-Fine trip home

\section{CHAPTER VIII}

\section{TO THE EASTWARD AGAIN}

Go for Malay money in s.s. Vicloria-Get out of Dobbo-Quick trip -s.s. Active-Goyder River-Darcy Uhr-Strike rock-In the M'Arthur-Borroloola-No grog or tucker-Trooper Donegan -Horses stolen and recovered-'Humping their Blueys'Digs his own grave-Donegan's work-Queensland policemanAssisted into river-Arrest of self-appointed Customs officers Prisoner stuns policeman-Kills black tracker-Black women and cattlemen-Nigger camp wiped out-'Killed to date, thirty-seven '-Life in own hands-Punishing niggers-Smart trick by blacks - Selling a booth-Up against a snag-Divorce demanded-Black tribes exchange children-Outlaw ruleLight side of policeman life in the out-beyond-Through mud and water-Start for Roper-Heavy flood--Smash some trees -At the Goyder River again-Two men murdered-Immense banyan - Larrikin escapes-Find damaged boat - See niggersMurderers recognised-Martini strong argument-Destroyed camp-Bad niggers-Florida Station-Start for home-Bad time

\section{CHAPTER IX}

\section{TO THE WEST IN SEARCH OF MALAY PROAS}

S.S. Adelaide - Plenty of sharks - See niggers - Hard pull-'Corpse reviver'-Search coast-Ferocious niggers-Port KeatsTerrible massacre-Boring party attacked-Peculiar raceCannitsals-Glass spear-heads-Treachery Bay-Why named -Captain Stokes speared-Bowing mangroves-'Look out, Searcy'-Niggers around us-Back to boat-Threatening niggers - 'Chin Chin Joss'-Fossil Head-No signs of Malays 


\section{CONTENTS}

\section{CHAPTER $\mathrm{X}$}

A TRIP TO THE VICTORIA RIVER

Through a tide race-Noble river-Dream unreali-ed-Holdfast Reach-Quicksands-Frowning sandstone ridges-Scowling sombre passes-Weird country-Terrible Mosquito FlatsHard work-Fearful tides-Jeering cockatoos-Curiosity Peak -At the depot-Jasper Creek Gorge-Niggers attack teamsters -Great sufiering-A duel-Glass spear-heads-Gregory's old camp-Baobab-trees-Timber Creek-Cutting out a flying-fox -Bromli kites-Cold south-easters-One hundred mile puil

PRGF

\section{CHAPTER XI}

\section{THE CAPE BROGDEN MASSACRE}

Rumours of the tragedy-Inspector Foelsche-Party leaves-Bowen Straits-Secure witnesses-Hard walk-Cape Brogden-Heavy surf - Difficult landing - Mangerippy - Peaceful sceneBloody work-Dig up bodies-Skulls and trousers-Search for an arrest of murderers-Wandy Wandy- 'Mr. Searcy, I no' do it '-Mangerippy tells the story-Strange proa-Qualitied judge -Murderer Wandy Wandy executed

\section{CHAPTER XII}

\section{EARLY MILITARY SETTLEMENTS-FORT DUNDAS}

Early experiences-Failure-Sail up Apsley Straits-Fort Dundas, Barlow Point-Old-time soldier-Ruins church-GraveyardNigger camps-Shelters and sleeping-places-Stone axesCycas media-Bark bags-Garden Point-Old bricks-A bogie -Sand-flies-Devil-devil-Bathurst Island-Buffalo tracks'Two canoes on cliff'-Nigger watching-Signal fires-Niggers - Arra boom'-Funny little ways-Down the Straits at night -'God help him !'-On the coral reefs-Buffalo camp-Hunter wounded-Poor Flynn-Good boys-Mainland boys-Mainland visited by Melville Islanders-Carry off women-Inferior weapons-De Rougemont's account impossible-Boy spearedSuccessful buffalo-hunters - Inbreeding - Island niggersReverence for dead-Canoes-The islands-Cultivation of rubber. 


\section{CHAPTER XIII}

\section{THE DALY RIVER}

My first visit-Alligators-Terrible death-Shooting the 'gatorsNiggers mauled-Another terrible death-Chinese fisherman mauled-Surveyors-Mosquitoes-Simply Hades-Great drive -Tall grass-Beautiful lagoon-Fine shooting-Copper-mine - Scene of great tragedy-Nigger telegraphy-ReprisalsChinese murderer-Miscarriage of justice-- 'Long-legged Charlie'-Expected gun accident-Borers-Jesuit Mission Station-Lynch amongst the niggers-Brutal murder-Don't like police or doctors-Sigh of peace-Spear in toes-Nigger grave-Signs of grief-Born deceivers-' Singing a man dead" Bore in Daly-At a plantation-Mosquitoes-Circus in netExperiences in a net-'Look out, Footsack, niggers'-Bad nigger country-Amongst the ducks-Great water-melonPlantation scene of tragedy-Miner wants a wash-In middle of river-Bunch of alligators-Another turn at the ducksAct 'slushy'-Great stew . . . . 206-2I4

\section{CHAPTER XIV}

THE ADELAIDE RIVER, AND MORE ABOUT ALLIGATORS

Fresh water required-Chinese water-carriers-Rice cultivation'All same Saigon'-Up the river-Game-Bag an alligator'Gator near baths-'Gator as tucker-Boy stung to death'Gator eggs 'all same hen eggs'-Kicked by an alligatorCapture by niggers - Increase of nests-Four days' shootingTaste for dogs-Niggers seized-Escape-'White pfeller doctor'-Beatrice Hills-Down the lazaret-Take in waterAmongst the pigmy geese- Getting through a lagoon-Collanse -Great shooting-Alligator alongside boat-Quiet niggers . 261-273

\section{CHAPTEK XV}

\section{STUART'S TREE}

Monument to Stuart-Arrival in A lelaide-old-time exploringSugar cakes-Non-discovery of landmark-Discovery-Visit to tree-Dead alligator-J. M. D. S. - Fine teeth-Stuart's party 


\title{
CONTENTS
}

\section{CHAPTER XVI}

\author{
ESCAPE CLIFFS
}

PACik:

Why named-Dancing to accompaniment of spears-First settle. ment - Dissatisfaction and insubordination - Forlorn HojeGreat waste of money-Men speared-'Punitive expedition!' Dombey and son-Kifle practice-Explorer M'Kinley-IIorsehide boat-Terrible voyage . . . . . 280.285

\section{CHAPTER XVII}

\section{INHUMAN BRUTALITY}

Brutal whice men-Horses shot, tomahawked, and hamstrungRingleader as a buffalo-shooter-Cold-blooded murderTerrible scene-Blaclis spear and strike body-Embezzlement -Murderer arrested-Kealistic acting by niggers-GuiltyImprisonment for life - Released - Trepanging - Nemesis around-Done to death . . . .

\section{CHAPTER XVIII}

\section{A SPORTSMAN'S PARADISE}

Jungles and lagoons-Day with the geese-'Hungry Flat'- All same old man goose'- Night at lagroon-With the kangaroo'Look out, kangaroo walk'-'Mr. Gun Breakem'-At the Casuarinas - 'Slushy'-Kangaroo-tail soup-Niggers cook their supper-New chums-'Out with the evening tide'-Good day's sport-Butcher disgusted-Wasps' nests-Close up short nigger-Hunting on horseback-Snakes-'Curpse'-Pythons -Caught by old soldier-Cane-brake-Black cockatoos-Fans -Uncanny bird-Marvellous intelligence-Frightens niggerOwner would not part with bird-Buried together-Beantiful small birds-Parrots-Game and snakes at Point CharlesVarm bath

\section{CHAPTER XIX}

\section{DEEP-SEA FISHING}

Fish plentiful-Many varieties - 'Town Hall' - Southport-Rushing waters-My canoe-Anchors-Sharks and Pedro-Canoe and shark-Bait-Prawns-Fine net-Kangaroo fish-Chinese 


\section{IN AUSTRALIAN TROPICS}

fishing nets-Sun-fish-Water-snakes-Turtle-Turtle eggs-

Alligators like turtle-Crabs-In the mud-Chance alligators-

Prawns .

\section{CHAPTER XX}

\section{PEARLING AND DIVING}

Swimming divers - Rush of boats - Rough crowd - Powerful Sergeant Waters - Peculiar prospecting - Japanese exploit industry-Wonderful medicine-Prosecute friend for smuggling -Won't speak - Hot day - 'Whisky and Soda' - Friends again-Fishing on pearling ground-Catch a diver-CrayfishGreat delicacy-So sharks think-Foul bottom-Divers tumble into holes-Beautiful marine growth . . . .

\section{CHAPTER XXI}

\section{WHITE ANTS}

Voracious pests-Pranks by white ants-Chinese benefit-Eat sheetlead-Bottled whisky into bulk-A. J. Gunn on the antsMan buried while asleep-Queensland Cypress Pine eaten by ants-Northern Territory Pine resists attacks .

\section{CHAPTER XXII}

\section{ABOU'T CHINESE AND OTHERS}

Law-abiding and industrious-Smallpox in Chinatown-Humpys burned - Arrival of Chinese - Landing-waiter goes madCauses trouble - Officer gets smallpox - Word his bondExpect develop pig-tail-Chinese hospitality-liring crackers - Chinese band - Nigger corroboree - Musical bambooChinese theatre - Joss-house - Joss displeased - Mining'Man along Pline Cleek - fool'-Yam Yan and his yawn - Chinese Court-Export duty on gold-Fate of smugglerSearching skeletons-Skcletons sent to China-Great temptation-Duty abolished-Smuggling opium-Cute dodge-Two pairs of trousers-Delivering letters-Gunpowder in luggageGreat opium robbery - Ride through goldfields - Watch for sampan-Permits changed-Sent back to Flowery LandStowaways-Given away by his nose- 'Mr. Custom-house, Esq. "- Sinking of lighter-Perseverance by white prisonerChinese oaths-Magistrate loses fowls- 'Bad debts to the credit of the Lord'-Horse-play-'The biter bit-Niggers' 


\section{CONTENTS}

love of strong drink-'All same water'-Babies smoking'Dods'-Nigger affection for employers-Cold water and flies - Custom-house Master-san-Japanese slipped upBitter magistrate-A particular official .

\section{CHAPTER XXIII}

\section{PORT DARIVIN}

Magnificent harbour-Sincrapore of Australia-Trans-continental Line-Great possibilities-Fortifications-Export of horses to India-Natural docks-Java and the Northern TerritoryCocoa-nuts-Pineapples finest in the world-The papya and tough meat-All tropical fruits-Red and black ants-Vegetables-Truth about the Territory-Malarial fever no bogyThe poor 'white elephant'-Healthy Europeans-Fine life on tablelands-Great opening for adventurous young Englishmen-Inducements-How to reach Port Darwin-Advice for settlers - The B.A.T. - 'Billy' - Native companions Steamers and their skippers-B.I. boat- 'Not a lot of coolies'-Epitome of a British seaman-A popular skipper .

\section{CHAPTER XXIV}

FAREWELL TO PORT DARIVIN

Transferred south-Craving to return-Nor'-westers-Farewell - 'What are you crying for?'-Mingo's gentle hint - $373 \cdot 374$ 



\section{LIST OF ILLUSTRATIONS}

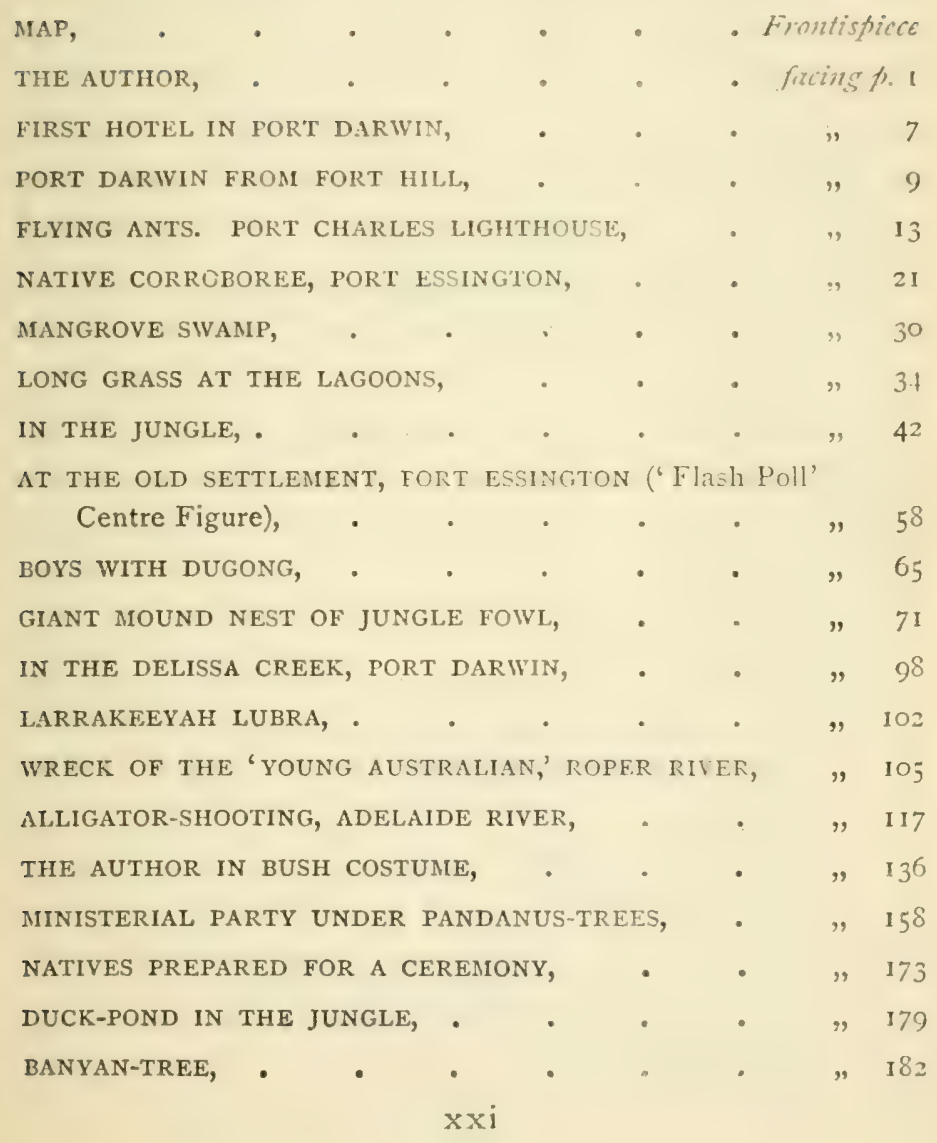


COCOA-NUT PALMS, facing p. 185

KATHERINE RIVER (I), 188

ABORIGINES RECEIVING RATIONS, POWELI, CREEK, • 193 DEPOT, VICTORIA RIVER, 200 GREGORY'S (BAOBAB) TREES, VICTORIA RIVER (I), 206 , ", " (2), , , 206

WOGITE AND BIERLY BOYS,

SOURCE OF THE EDITH RIVER IN THE TABLELANDS, 2 I I CHINESE FISHING-STATION AT THE MOUTH OF THE DALY, , 22 I $24 \mathrm{I}$ DALY RIVER, NEAR OLD MISSION-STATION, . 243 FLORA FALLS 247

BLACK FELLOW'S GRAVE, 253 KATHERINE RIVER (2), . 259 ADELAIDE RIVER, PINE CREEK RAILIVAY, • . " 26 I ADELAIDE RIVER CROSSING, PINE CREEK RAILWAY, ALLIGATOR, TWELVE FEET SIX INCHES LONG, 263 ROUGH ON ALLIGATORS, LANDING, BEATRICE HILLS, ADELAIDE RIVER, 264 268 STUART'S TREE, ON THE ELIZABETH, BURKETT CREEK, COCKY AND HIS OWNER, THE JETTY, SOUTHPORT, LIGHTHOUSE-KEEPER'S SON AT POINT CIIARLES RIIING

A TURTLE A LA DE ROUGEMONT, . . " 3 I 2 PEARLING LUGGERS, • • • • • " 315 ANT-HILL, NEAR RUM JUNGLE, . . . " " 322 MERIDIONAL ANT-HILL, . PORT DARIVIN HOSPITAL, AND CHINESIE GARDENS, · , 33 I NATIVES DRESSED FOR CORROBOREE (PORT DARWIN), " " 335 PORT DARIVIN NATIVE, . 


\section{LIST OF ILLUSTRATIONS}

NATIVE WOMAN, PORT DARWIN, - , . facing p.350 FORT HILL AND CAMP, PORT DARWIN, . • " 355 PAPYA OR PAWPAW APPLE-TREE, BEARING, ELEVEN MONTHS OLD, . . . . . " 359 FINEST PINEAPPLES IN THE WORLD, • • • : 36 I JERYOIS ROAD (LUVERS' WALK, PURT DARWIN), • " 364 





\section{CHAPTER I}

THE NORTHERN TERRITORY

THE name Northern Territory indicates the northern portion of the Australian continent which was annexed to South Australia by Royal Letters Patent in $I \delta 63$. This vast region contains 523,620 square miles, or $335,116,800$ acres, a territory in area equal to France, Germany, Holland, Belgium, Switzerland, and Italy combined. It is bounded on the north by the Arafura Sea or Indian Ocean; on the south by the 26 th parallel of south latitude; on the east by the 13 Sth meridian of east longitude; and on the west by the r29th meridian of east longitude. With the exception of two and a half degrees, it is all in the tropics or Torrid Zone. The whole coast-line is indented with good-sized bays and estuaries, forming in many instances grand harbours, and dotted with islands. Without including the latter, it has about two thousand miles of seaboard.

The coast, as a rule, is low and flat, bounded by sandy beaches, but chiefly with mud flats and mangroves. At one time it was considered that the interior of this vast territory was a barren desert, but the discoveries of explorers have proved that a fallacy. It is now recog. 


\section{IN AUSTRALIAN TROPICS}

nised that there is an almost unlimitcd area of country suitable, and not to be beaten in the world, for cattle and horse breeding. Besides the great extent of country on the coast-line and rivers, upon which every description of tropical product can be grown, there are immense areas inland suitable for agricultural purposes. It is well known that the Territory is rich in all sorts of minerals. The area prospected so far is very small indeed, so there are immense possibilities in the future in this direction.

The wet season begins about the end of October, and lasts approximately five months. The rainfall during January and February is very heavy. The average rainfall near the coast is sixty-five inches. The maximum temperature during the wet season is ninety-five degrees, and the minimum at night sixty-five degrees. Dry heat prevails during the south-east monsoon, but it is not extremely hot except just prior to the setting in of the rainy season, and up to the end of December, when the north-west monsoon as a rule sets in strongly.

In a few words I should like to give some particulars of the very early adventurers who were the first to sight and visit the north coast of Australia. To me the subject is marvellously attractive, and is surrounded by great romance. When one thinks what the old sea-dogs of centuries ago accomplished in the miserable vessels of their day, one can only wonder and admire their pluck and grit. I can fully understand their feelings when approaching and visiting a country previously unknown to the civilised world, for in a small way it has been my 


\section{EARLY ADVENTURES}

privilege to sec some of our country and the inhabitants which had never before been visited or scen by white men, at any rate not for centuries. Perchance the old voyagers had dreams of fabulous riches in the great continent, which, there scems to have been a hazy idea, existed under the Southern Cross. The appearance of the natives evidently banished the idea of any such wealth existing. The black men did not make an impression on the adventurers. One dismissed them with the description: 'Black, naked, and corpulent.'

Dampier, the first Englishman to visit and land on the great island-the continent which was to become such an important part of the British Empire-wrote: 'The inhabitants of this country are the miserablest in the world.' Judging from his narrative, Dampier must have been unfortunate in meeting very poor specimens of the inhabitants of this new land, and probably at a time of the year when flies were exceptionally bad. This was in I688.

A shadowy claim to being the first discoverer of Terra Australia has been advanced on behalf of De Gonneville, who sailed from Honfleur in 1503 . There is cartographic evidence that between I 5 I 2 and I 542 the north coast of Australia had been discovered. In the British Museum there is the rough copy of an old map which indicates that the north coast of Australia was discovered in 1601 by Manoel Godinho Eredia. This would point to a Portuguese discovery of Australia immediately prior to the Dutch one. In 1605 Louis Vaez de Torres touched at Cape York. Torres Straits were named after 


\section{IN AUSTRALIAN TROPICS}

him. Arnheim Land, which is in the Northern Territory, was discovered by the crew of a Dutch vessel named the Arnheim. The captain and some of the crew of this vessel had previously been murdered by the natives in New Guinea. In I644 Tasman coasted all along the north and north-west coasts. Many of the names still retained in the Gulf of Carpentaria are significant of Tasman's visit - Vanderlin Island, after Cornelius Van der Lyn ; Sweers Island, after Salamon Sweers; Maria Island, after his supposed sweetheart, Marie Van Diemen; and Limmen Bight, after his ship the Limmen. It was in 1628 that a Dutch expedition left the Zuyder Zee with the idea of forming a settlement on the coast of New Holland. The wreck of the Batavia during the following year on Houtman's Abrolhos ended in one of the most tragic incidents in the early history of Australia. The terrible story is most graphically told by W. J. Gordon in his book, The Captain General.

Looking back to the far-off days when these brave old sca-dogs ploughed their way through unknown seas with such marvellous intrepidity, one's imagination might easily run riot in thinking of 'the might have beens' had any of the pioneer adventurers had sufficient luck or foresight to have planted themselves upon the north shores of this fair continent. If they had realised for a moment the untold wealth concealed in this new land, or the fabulous riches hidden by the sea through which they sailed when near the coast, another Java might have been evolved to the definite settlement of the coloured labour problem, and probably the Union Jack 


\section{NEW HOLLAND}

would never have floated over these bounteous lands, unless, perchance, by right of conquest.

If the settlement had been made by any other nation, I expect it would only have supplied another evidence of the fact that the Anglo-Saxons are the only people who can colonise successfully.

Sir William Temple, who was ambassador at the Hague in the time of Charles II., wrote to the effect that a southern continent had long since been found out, that it was as long as Java, and marked on the maps as New Holland, but to what extent the land extended south, east, or west, none knew; also that he heard it said among the Dutch that their East India Company ' have long since forbidden, and under the greatest penalties, any further attempts at discovering that continent, having already more trade than they can turn to account, and fearing some more populous nation of Europe might make great establishments of trade in some of these unknown regions, which might ruin or impair what they already have in the Indies.'

As bearing upon the discovery of gold in the Northern Territory, I may mention that on some maps a part of the country is named 'Terra Arafura,' a name taken presumably from the adjoining Arafura Sea, but I am given to understand that there is an old map in the British Museum on which this territory is named 'Terra Aurifera,' indicating that the presence of gold in those parts was known in remote times. In support of the fact that there were ancient visitations to the coast, I may mention a discovery by a man named Peter Erickson, an old 


\section{IN AUSTRALIAN TROPICS}

Port Darwin resident. He once procceded to the north-west for the purpose of pearling, and landed at Cape Bougainville (a most notorious place for bad niggers) to search for water. Erickson, who was fortunate enough to find a stream of fresh water, also discovered an ancient cannon. The idea is that it was mounted here for the protection of ships while they were watering. Erickson gave the cannon away for a compass to a fellow-countryman, who took it to Norway or Sweden. It was a pity that Erickson did not bring the gun back with him instead of parting with it. If he had looked for some indication of when and where it was made, it would have been some guide, but he did not even do that. That the gun was very ancient there can be no question.

When a boy I read a book called Oliver Ellis, in which mention is made of a sunken Spanish galleon, from which the hero of the story procured great wealth. While on my voyages down the coast I had this novel in my mind, and I did a lot of looking for treasure, until I realised that the scavengers of the seas, the Malays, had been centuries in advance of me.

In other chapters my readers will find what the English have done on the north coast during the last century.

It is a long way from the 'Dingo,' the wild dog of Australia, and one of the greatest pests with which the settlers have to contend in the 'out-back' of this sreat land, and the adventurers of centuries ago. It must be unierstood that the dingo is the only animal 



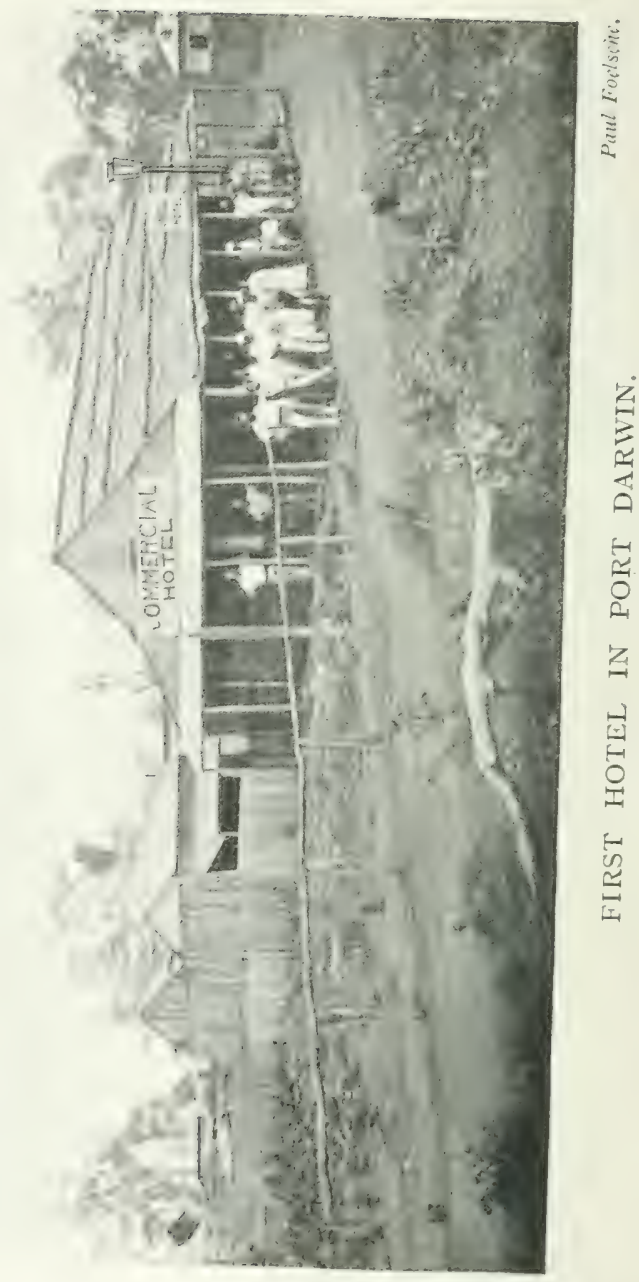




\section{THE DINGO}

in Australia which does not possess a pouch. Many authorities have advanced the idea that the animal has descended from the chow dog, or something akin to it. When it is rememberel that communication took place between the Chinese and Portuguese so many centuries ago, it might reasonably be surmised that the animal from which the dingo has sprung was landed on the north coast by some of the old navigators. Dampier in his diary says: "We saw no sort of animal, nor any tracks of beasts but once, and that seemed to be a beast as big as a great mastiff-dog.' Ie may have struck a number of kangaroo tracks. 


\section{CHAPTER II}

\section{WHY I WENT TO PORT DARWIN}

IT was in June I882 I sailed from Port Adelaide for Port Darwin, and in a few words I would like to explain why I went there. The Minister controlling the Northern Territory (the late Hon. J. L. Parsons) had paid a visit to our northern dependency, and as a result it was decided that some radical changes in the administration should be initiated, the idea at the time being to bring the Northern Territory into line with South Australia proper, as far as the tariff was concerned. After being a free port for some years Port Darwin had had a special tariff since I8SO. Such being the case, the necessity for sending an officer experienced in the tariff arose. I was a landing waiter at Port Adelaide at the time, and being considered suitable, was requested to volunteer, which I did, and in due course was appointed sub-collector. I sailed from Port Adelaide in the s.s. Catterthun, then a new boat. This steamer, I might mention, was some years afterwards, when on a voyage to China vicî Port Darwin, totally wrecked just after leaving Sydney, with great loss of life. As usual we called in at Sydney, the city with the beautiful harbour, for cargo and passengers. 



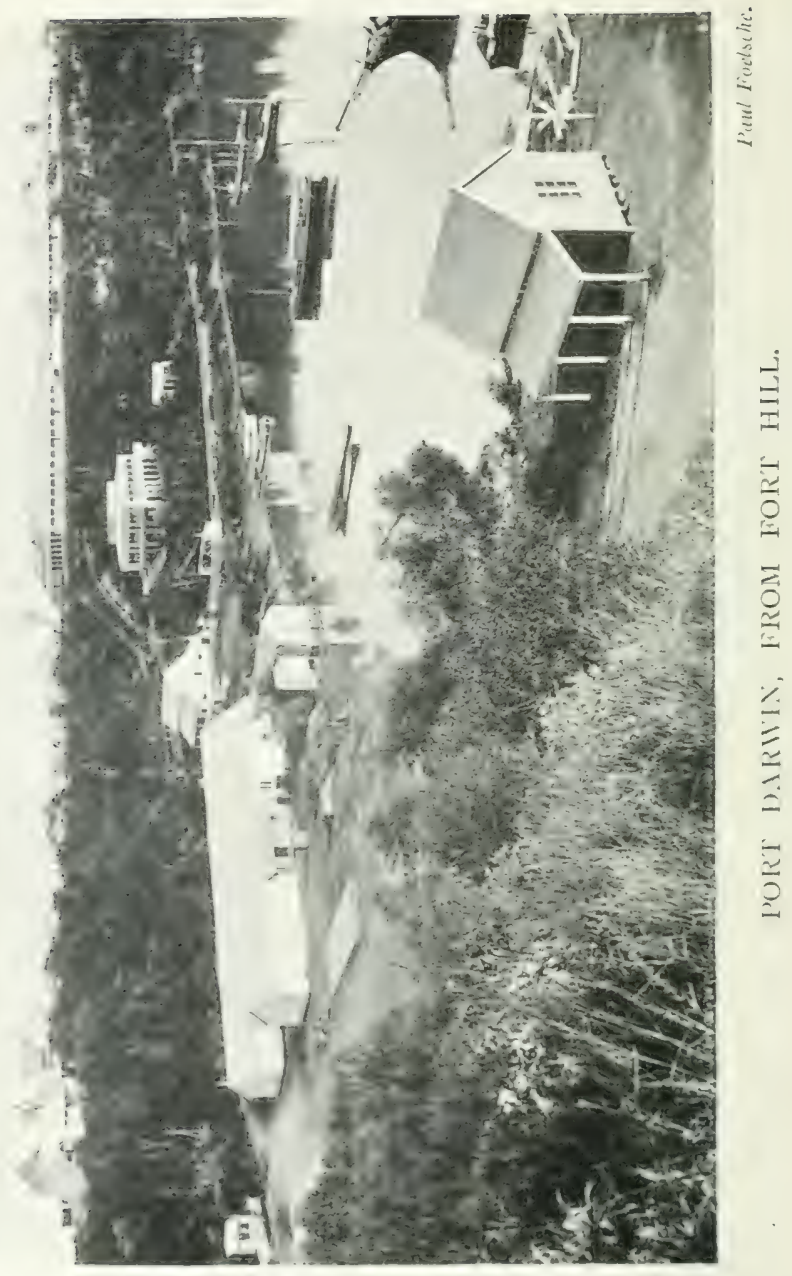


When we left we were full up with general cargo, with forty horses and twenty-five bulls on deck. The passengers consisted of fifty-six Europeans, and many Chinese homeward bound. We touched at several Queensland ports and shipped more Chinese, so when we finally cleared from Thursday Island, the last port of call, we had some four hundred Celestials on board. In spite of our crowded condition the voyage was most enjoyable, especially the run from Brisbane to Thursday Island through the Barrier Passage, the waters of which are sheltered by the famous reef for a distance of some one thousand miles. The gradual approach of the tropics was full of interest. The sea a sparkling sapphire, and the sky a cloudless indigo, were charged with wonderful glories. We passed through numerous islets, many of which were rarely, if ever, visited, while few were settled. Then came the romantic scenery of the Whitsunday Passage, with its emerald green foliage right down to the water's edge. This is admittedly one of the most beautiful places in the world.

We navigated the narrow waters between Albany Island and Somerset on the mainland, the residences at the latter place being enveloped in luxuriant tropical growth, and one felt he would like to be a lotus-eater and dwell there for ever.

Although I passed up and down the Barrier on several subsequent occasions perfect weather invariably prevailed, but there are times when the conditions are just the opposite. At certain seasons of the year many of the islands in the passage are frequented by vast numbers 


\section{IN AUSTRALIAN TROPICS}

of black and white pigeons, known as Torres Straits pigeons. Steamers are frequently stopped off one of those islands to give the passengers a chance of making a bag. I was one of a party on one occasion, and we shot great numbers of the birds.

The coast of Queensland is rich in historical events and tragedies, and with the outlying reefs, memorable as the scene of many wrecks. The passage at one time was a most dangerous piece of navigation, but now, owing to the fact that it is so perfectly lighted and buoyed, the risk is reduced almost to a minimum.

Several of us were rather fond of mixing with the Chinese passengers, but the skipper put a stop to this when one day he found us playing fan-tan with the Asiatics, and getting the best of it. Several Chinese died during the voyage, and, as usual, the friends of the deceased made arrangements with the officers to have the bodies headed up in pickle or simply embalmed and stowed away in solid wooden coffins in the coal-bunkers, so as to enable the bones to be deposited in the Flowery Land-the real ambition of all Celestials.

In due time we arrived off Cape Don, the entrance to Van Dieman's Gulf, a distance of one hundred miles from Port Darwin. It was evening, and being aware that we should have to anchor during the night, as it would be unsafe to navigate Clarence Straits, some sixty miles further on, the skipper, in answer to a question, said he would anchor at 2.30 A.M. Shortly before that time arrived, however, the passengers received a great surprise, for thete was a tremendous er-r-r-r-r , and the screw 


\section{PORT DARWIN}

stopped. We were on the top of the reef all right, the steamer having overrun her distance a little. Fortunately there was no wind, and beyond a little ocean swell, no sea. The range was just sufficient to give us a reminder, by way of a bump, which made things rattle, that we were not afloat. There was no excitement. Just before noon we came off apparently uninjured, but when the steamer was subsequently docked at Hong-kong it was found necessary to put in several new plates.

It was dark on Sunday evening when we dropped our anchor in Port Darwin, the name of the town being Palmerston. And so commenced for me a residence of fourteen years in the tropics. Ever since I have "eard the East a-callin'.

During my long residence I had many exciting and dangerous yoyages on the coast in carrying out my duties as sub-collector, which, with other experiences, I purpose relating in as simple a manner as possible.

The Port Darwin Custom-house was a large iron shed on the beach near the landing-stage, known as Gulnare Jetty. The floor, which stood some three feet off the ground, was of wood; or rather what the white ants had left of it was (of white ants more anon!), so it was no unusual occurrence for a foot to go through, or the legs of your chair to sink out of sight, and, as can be imagined, strong language was used at times when such accidents happened.

I never shall forget the impression the place made on me when sitting at work between the open doors of the Custom-house on some of the still, steaming mornings 


\section{IN AUSTRALIAN TROPICS}

before the sea-breeze set in. From the wide-open door I could see the glassy sea fringed by dark mangroves, and backed by forest and jungle. A steamy, heavy smell arose from the mud and sand left by the receding tide. Then there were the crowing of cocks and the squealing of pigs emanating from the mass of bark or grass humpys, or huts, built on the side of Stokes' Hill, a short distance away, and occupied by Chinese and Malays, the owners of the porcine grunters and poultry in question. The Asiatics and the animals all lived together, for sanitation was not a strong feature in Darwin in those days. Whenever I hear a clarion cock crow, in a flash I imagine myself in the cane chair panting and wet through with perspiration; and the sea, the smell, the mangroves, and Stokes' Hill come back to me all over again.

The first day ashore I had an interview with a scorpion and a centipede, and at dinner I discerned four marsh flies in my soup. It was good soup, too. This was only a sample of the little pleasantries one has to put up with in the tropics, and it is surprising how quickly one gets accustomed to them. 


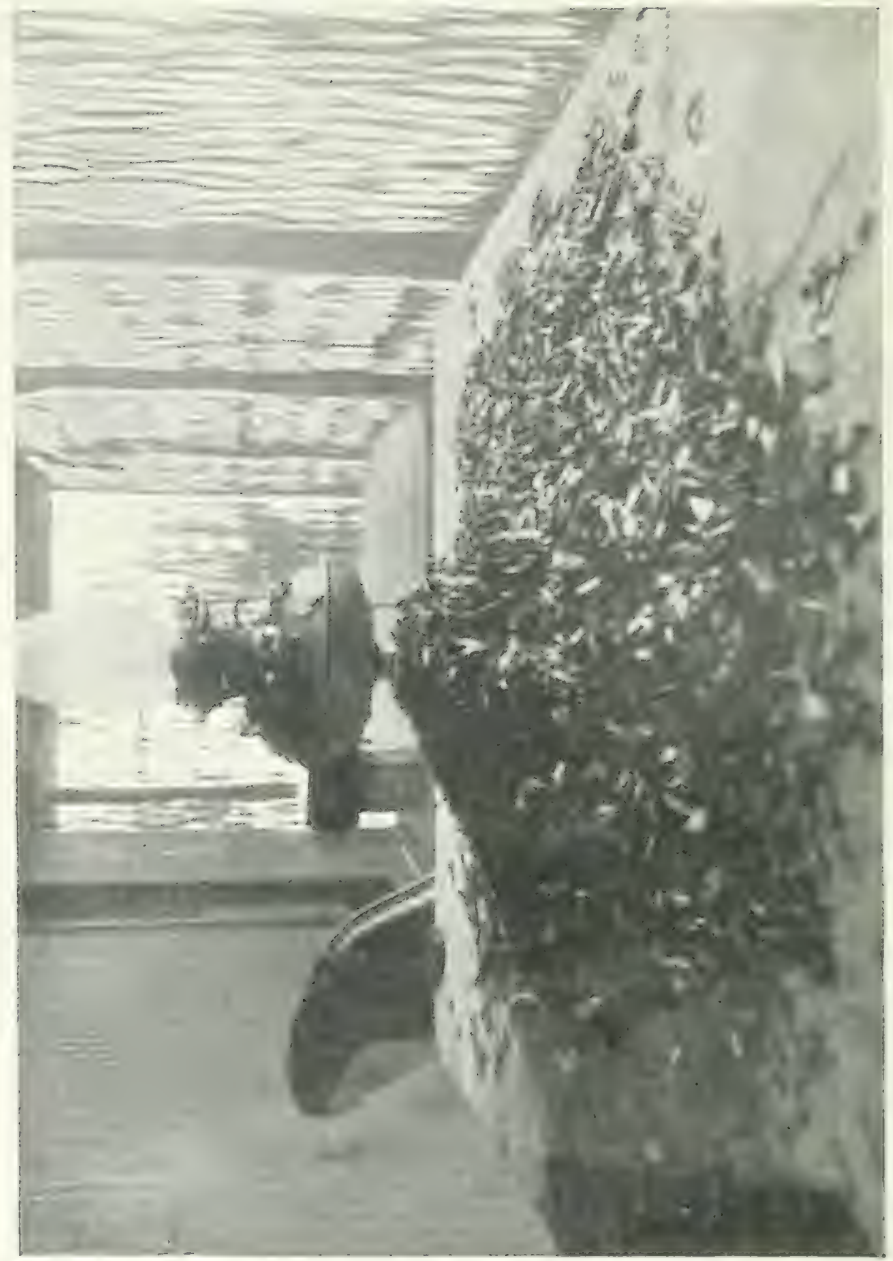




\section{CHAPTER III}

\section{FIRST VOYAGE IN THE 'FLYING CLOUD'}

IT is well known to those who are acquainted with the history of the Eastern Archipelago and of Northern Australia that for a long period-probably centuriesthe Malays paid annual visits to the northern coast of this continent, and carried off the spoils of its beaches and shallow waters to Macassar. So long as this portion of the coast was waste there was no reason why the Malays should not gather the annual harvest and turn it to their own profitable account. But now that there was some chance of Europeans followiner suit, and with the idea of encouraging local trading on the coast, it was decided that the time had come for the Malays to be placed on an equal footing with the local people, and to pay something towards the revenue of the country, to which hitherto they had not contributed a penny, although they had removed from the coast millions of pounds' worth of spoil in the shape of trepang, pearls, pearlshell, tortoise-shell, and timber.

It having been decided that action should be taken, I made preparations for my first voyage down the coast to warn the masters of the proas that in future a licence 


\section{IN AUSTRALIAN TROPICS}

would have to be paid, and also duty on the stores used on the coast. The stores consisted of rice, arrack, and tobacco, great quantities of which were tendered to the natives in the way of barter and for help rendered in the trepanging operations.

The Macassar proas were discovered on February I7, I 803, in the 'Malay Road,' south of the Cotton Islands (English Company's Islands), by Captain Flinders; and on March 27, 1884, when on a cruise in search of proas which had failed to procure the necessary licences, I anchored in almost the identical place where Flinders first sighted them in February 1803, eighty-one years before.

The following extracts from Captain Flinders's Voyage to Torra Australis, published in 1814, are extremely interesting: "Thursday, February 17, 1803.-After clearing the narrow passage between Cape Wilberforce and Bromby Isles, we followed the main coast to the southwest, having on the starboard hand some high and large islands, which closed in towards the coast ahead so as to make it doubtful whether there was any passage between them. Under the nearest island was perceived a canoe full of men, and in a sort of roadstead at the south end of the island there were six vessels covered over like hulks, as if laid up for the bad season. Our conjectures were various as to who the people could $\mathrm{bc}$, and what their business here; but we had little doubt of their being the same whose traces had been found so abundantly in the gulf. I had inclined to the opinion that these traces had been left by Chinese, 
and the report of the natives in Caledon Bay that they had firearms strengthened the supposition; and combining this with the appearance of the vessels, I set them down for piratical ladrones, who secreted themselves here from pursuit, and issued out as the season permitted or prey invited them. Impressed with this idea, we tacked to work up for the road, and our pendant and ensign being hoisted, each of them hung out a small white flag. On approaching I sent Lieutenant Flinders in an armed boat to learn who they were, and soon afterwards we came to an anchor in twelve fathoms, within musket-shot, having a spring on the cable and all hands at quarters. On the return of Lieutenant Flinders we learned that they were proas from Macassar, and the six Malay commanders shortly afterwards came on board in a canoe. It happened fortunately that my cook was a Malay, and through this means I was able to communicate with them. The chief of the six proas was a short elderly man, named Pobassoo; he said there were upon the coast in different divisions sixty proas, and that Salloo was the commander-in-chief. These people were Mahometans, and on looking in the launch expressed great horror to see hogs there. Nevertheless they had no objection to port wine, and even requested a bottle to carry away with them at sunset. In the morning (Friday r8) I went on board Pobassoo's vessel with two of the gentlemen and my interpreter to make further inquiries, and afterwards the six chiefs came to the Investigator, and several canoes were alongside for the purpose of barter. Before 


\section{IN AUSTRALIAN TROPICS}

noon five other proas steered into the road from the south-west, anchoring near the former six, and we had more people about the ship than I chose to admit on board, for each of them wore a short dagger or creese by his side. My people were under arms, and the guns were exercised and a shot fired at the request of the chiefs. In the evening they all retired quietly, but our guns were kept ready, and half the people at quarters all night. At daylight the proas got under sail and steered through the narrow passage between Cape Wilberforce and Bromby's Isles, by which we had come, and afterwards directed their course south-eastwards into the Gulf of Carpentaria. According to Pobassoo, from whom my information was principally obtained, sixty proas, belonging to the Rajah of Boni, and carrying one thousand men, had lcft Macassar with the north-west monsoon two months before, upon an expedition to this coast, and the fleet was then lying in different places to the westward-five or six together-Pobassoo's division being the foremost. These proas seemed to be about twenty-five tons, and to have twenty or twenty-five men in each. That of Pobassoo carried two small brass guns obtained from the Dutch, but the others had only muskets, besides which evcry Malay wears a creese or dagger, either secretly or openly. The object of their expedition was a certain animal called "trepang." Of this they gave me two dried specimens, and it proved to be the beche dc-mer or sea-cucumber. They get the trepang by diving in three to eight fathoms of water, and where it is abundant a man will bring up eight or 
ten at a time. The mode of preserving it is this: The animal is split down on one side, boiled, and pressed with a weight of stones, then stretched open by strips of bamboo, dried in the sun and afterwards by smoke, when it is fit to put away in bags, but requires frequent exposure to the sun. A thousand make a picol of about one hundred and twenty-five Dutch pounds, and one hundred picols are a cargo for a proa. It is carried to Timor-Laoct and sold to the Chinese, who meet them there, and when all the proas are assembled the fleet returns to Macassar. There are two kinds of trepang. The black, called "baotoo," is sold to the Chinese for forty dollars the picol ; the white or grey, called "koro," is worth no more than twenty dollars. In the Gulf of Carpentaria we did not observe any other kind than the koro or grey slug. Pobassoo had made six or seven voyages from Macassar to this coast within the preceding twenty years, and he was one of the first who came, but he had never seen any ship here before. This road was the first rendezvous of this division to take in water previously to going into the gulf. One of the proas had been lost the year before, and much inquiry was made concerning the pieces of wreck we had seen, and a canoe's rudder being produced, it was recognised as having belonged to her. They sometimes had skirmishes with the native inhabitants of the coast. Pobassoo himself had been formerly speared in the knee, and a man had been slightly wounded since their arrival in this road. They cautioned us much to beware of the natives. They had no knowledge of 


\section{IN AUSTRALIAN TROPICS}

any European settlement in this country, and on learning the name of Port Jackson, the son of Pobassoo made a memorandum of it. I could find no other nautical instrument among them than a very small pocket-compass, apparently of Dutch manufacture. By this their course is directed at sea, and without the aid of any chart or astronomical observation. They carry a month's water in joints of bamboo, and their food is rice, cocoa-nuts, and dried fish, with a few fowls for the chiefs. My numberless questions were answered patiently and with apparent sincerity. Pobassoo even stopped one day longer, at my desire, than he had intended, for the north-west monsoon, he said, would not blow quite a month longer, and he was rather late. I rewarded his trouble and that of his companions with several presents, principally iron tools, which they seemed anxious to possess, and he begged of me an English jack, which he afterwards carried at the head of his squadron. He also expressed a desire for a letter to show to any other ship he might meet, and I accordingly wrote him a letter to Captain Baudin, whom it seemed probable he might encounter in the gulf, either going or returning. I made many inquiries concerning the Malay trepang fishers whom we had met at the entrance of the Gulf of Carpentaria, and learned the following particulars: The natives of Macassar had been long accustomed to fish for trepang among islands in the vicinity of Java and upon a dry shoal lying to the south of Ruttee, but about twenty years ago one of the proas was driven by the north-west monsoon to 


\section{PORT ESSINGTON}

the coast of New Holland, and finding the trepang to be abundant, they afterwards returned, and had continued to fish there since that time. The Governor was of the opinion that the Chinese did not meet them at Timor-Laoet, but at Macassar itself, where they had been accustomed to trade for birds'-nests, trepang, sharks' fins, etc., and it therefore scems possible that the proas rendezvous only at Timor-Laoet on quitting Carpentaria, and then return in a flect with their cargoes. The value of the common trepang at Canton was said to be forty dollars the picol, and for the best or black kind sixty, which agrees with what I had been told in Malay Road, allowing to the Chinese the usual profit of cent. per cent. from Macassar to their own country:'

My idea was to meet the proas in the neighbourhood of Port Essington, as they had to pass there on their way up the coast with the south-east monsoon when returning home to Macassar. It was in the cutter Flying Cloud, 28 tons, Captain H. R. Marsh, we made a start in March I883. We had little wind during the voyage, so it became a matter of fairly working the tides nearly all the way to Port Essington, a distance of nearly one hundred and fifty miles, which we accomplished in five days. It satisfied me that steam was most necessary for any work on the coast. We sailed right up the bay to the old settlement named Victoria, where Mr. E. O. Robinson, manager of the Coburg Cattle Company, buffalo-shooter, trepanger and customs officer, had his camp, and a most charming and picturesque spot it was. Imagine a glade of sevcral acres in extent, with a gentle slope right down 


\section{IN AUSTRALIAN TROPICS}

to the beach, kept clear of all undergrowth and surrounded by forest and jungle. In the centre of the clearing was a clump of large tamarind-trees of great age, under which the little house and outbuildings nestled. On a rise at one side were the ruins of the old military settlement, for such Port Essington was from 1838 to 1849 . Close to the beach at one side was the niggers' camp, formed of bark humpys.

As soon as our anchor was down Robinson came on board, dressed, for it being an auspicious occasion he had shipped some clothes. His full dress, I subsequently found, consisted generally of a strap and revolver. Robinson, from his long association with the niggers, extending over some years, thoroughly understood them, and they understood him, for he was feared and respected, if there is such a thing as respect in the blacks. I fancy fear had more to do with Robinson's unquestioned authority than anything else. $\mathrm{He}$ was always on his guard, and always kept his word with a nigger. If he said he would give one a stick of tobacco, he would do so; and if he said he would break a man's head, he would carry out his threat. I've seen him do it. I have known Robinson to be with the niggers for nine months at a time, and no white man nearer than Port Darwin. He was a wonderful billiard player, as the fellows in Darwin found out, for he gencrally took them down, although away from the table for so many months at a time. As a matter of fact, he was one of the best amateurs with the cue in Australia.

The reason of Robinson's settling at Port Essington, 



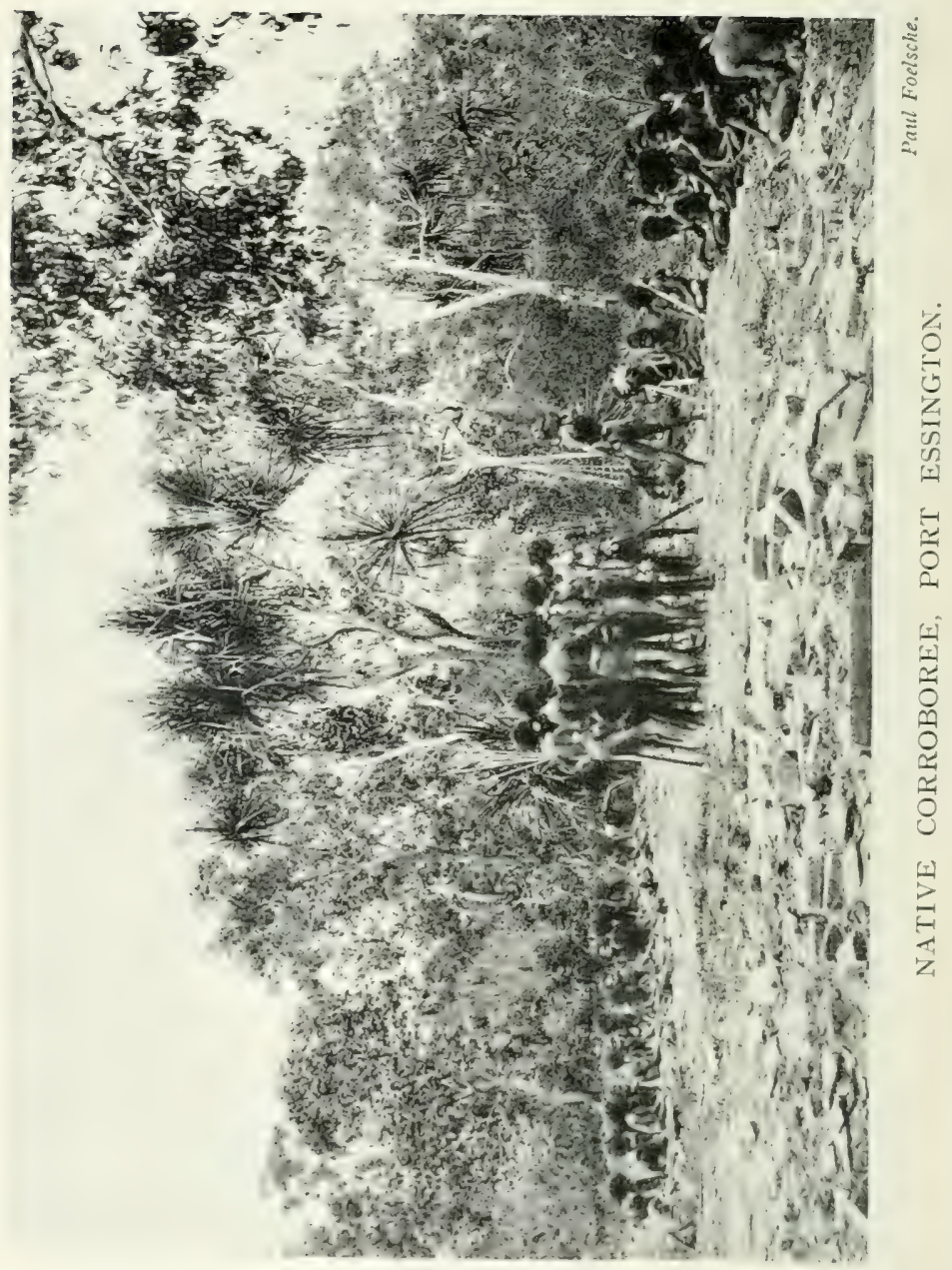


and leading the life he did, was because he had a 'dead horse' to work off. After knocking about the coast for some years, pearling, trepanging, and buffalo shooting, he and a mate named Wingfield settled at Adjaka, Crocker Island, for the purpose of trepanging. They formed a comfortable homestead, and cultivated a patch of ground, in which, among other things, they grew some fine tobacco. One day during Robinson's absence the niggers murdered Wingfield. When Robinson returned, his welcome was a ransacked hut, and the body of his mate buried in the sand close to the hut. Part of the face was exposed, and the fowls were pecking at it. Of the murderer I will have more to say later on.

Having incurred certain liabilities in forming the home at Crocker Island, Robinson undertook to work them off. This he did, and effectually buried the 'dead horse' at Port Essington.

Some years later, Robinson had an exciting experience when running from Bowen's Straits to Port Darwin in his lugger the Bertie. There were on board besides the owner two black men and a gin. When off Port Bremer terrible weather was experienced, and the lugger was capsized. The gin went down in the boat; Robinson and the two niggers swam ashore on hatches, a distance of eight miles. When they landed they had forty miles to walk to camp. Well, to return to my story!

As no proas had as yet turned up, it was decided to proceed next morning a little to the eastward, with a view of meeting them. Just before starting the niggers 


\section{IN AUSTRALIAN TROPICS}

brought off a very fine turtle, so we were able to indulge in turtle steak and soup to our hearts' content. Robinson having joined us, we started, and when clear of the heads, sighted a proa bowling along before the southeaster. The Customs flag and pendant were hoisted as a signal for the master to heave to, but beyond hoisting his colour (Dutch) it seemed as if the signal were to be ignored. I told our skipper that a shot (out of a rifle; we had no cannon) would have to be fired across his bows as a gentle hint, and if that were not sufficient, a shot would have to be fired into him. The skipper got mad, and said nothing like that should take place aboard his vessel, but a reference to a certain section in the Customs Act satisfied him that I had the power to do what I said. However, the necessity for such drastic measures did not arise, as the proa was hove to and her sail rolled up. In response to my order the master came on board in a canoe. He had evidently shipped his Sunday clothes, judging from the gorgeous silk saarong and other fixings. The Malay appeared to be greatly frightened when handing me his papers, for I had put on my uniform. He had been accustomed to Dutch officials, and apparently had an idea that he had run up against a snag when he saw the gold braid and brass buttons. As soon as he had a chance, he whispered to Kobinson, who spoke Macassar, and whom he knew, that he would give him some pearls as big as the top of his finger. This was by way of a bribe. Needless to say Rribinson did not get the pearls. This proa proved to be the Lambiro Dynna, Ban Kassic, master, from 


\section{PROAS}

Dylompo, the Nalay name for a fishing camp in Groote Island, Gulf of Carpentaria. The proa was full up, so was homeward bound. That Ban Kassie had a large number of pearls, some of great value, I found out later from other Malays and niggers. I then regretted that I had not boarded the proa. Ban Kassie, as well as all the other Malay's I met, received instructions that when they came down with the next nor'-west monsoon, they were to meet me at P'ort Essington, and to bring money -English—with them, so as to pay up. I informed them that any proas running past in the future, and fishing without the necessary licence, would mean sorrow for the masters.

Next evening we ran into Bowen Straits, and sighted twelve large dredging canoes coming down before the wind, and hauling the great trepang dredgers. What a chance that would have been for a marine artist. The twelve canoes, which were almost in line, had their immense mat sails hoisted on the triangular mast, and were gliding through the rippling water; on either side of the straits was the glistening sandy beach backed by forest trees and jungle, while just beyond the canoes were four proas at anchor, close to the beach, on which the Malay camp was formed. We beat up to where the proas were anchored, and dropped our mud-hook. This place was called by the Malays Oojountambanoonoo, the native name being Adjaka.

In accordance with orders, the masters were soon on board, all in gorgeous array, and produced their papers. These proas proved to be the Erang Polen, Saga, master; 
Bonding Katupa, Bapa Paloe, master; Pattie Dyawaya, Dantoona, master; and the Lakarenling, Reimba, master. Having given the Malays their instructions and a glass of squareface, I sent them back to their several vessels to await my inspection. One and all agreed that it was a fair thing to pay up, but subsequent events proved that some at least had altered their opinion.

The proas are most peculiar-looking concerns, and present a most clumsy appearance. The hull is of wood, and the top, sides, deck, roof, and yards are made of bamboo, the sails of matting, and many of the ropes and hawsers of plaited cane. They are steered by two rudders, one on either side of the stern. Some of them carry iron anchors, others wooden ones with heavy stones lashed to them. Often when the anchor is let go, a man is sent down to see that it is properly fixed in good holding ground. The mast is very peculiar, being formed of wood or bamboo, having two stays, so that in appearance it resembles a lengthy trident, the spaces between the masts and stays being fitted with wooden steps, on which the sailors stand to hoist and roll up the sail, which unrolls again by a simple contrivance like a window blind. The orthodox way of getting on board is over the bow, that being close to the water's edge, the stern being away up in the air. You then climb a beam, and step across an opening to the deck in front of the captain's cabin, which is situated on one side of the bows, a similar one being on the opposite side for the second in command. The deck is of split bamboo, worked together with wire or fibre, and can be rolled up at pleasure. The 
entrance to the cabins is about 2 fect by 2 fect $\sigma$ inclies. Of course, to enter or leave you must go on your hands and knees. Inside there is room for a man to sit or lic down. The stern, which is high up, has several small rooms, or holes, like a great pigeon-house, and in these and on the top of the cargo the crew live, the galley being a large iron pan with a quantity of sand in it on which to light the fire. The proas have a sort of bowsprit rigged out, and sometimes carry two or three head sails. On top of the houses they carry plenty of spare bamboos and rattans, which they get at the island of Kissa, near Timor, on the way down.

The proas visiting the coast varied from ten to thirteen tons measurement.

On board all the proas were numbers of very ancient cannon, which seemed to be much prized by the Malays, and which, I should imagine, were regarded as heirlooms, having apparently been handed down from father to son. The masters had some beautiful creeses, but I could not persuade them to part with any.

I had with me, as one of my boat's crew, a Malay named Cassop. On my telling him he had to go with me, he requested to be supplied with a revolver, for, to use his own words, 'Macassar boys very bad, all same white men.' I lent him a shooting-iron. As I have said, judging from appearance, some did look bad, but it struck me afterwards that Cassop wanted to 'put on side.' At anyrate, it looked like it, when I saw him stalking about amongst the other Malays in his nice 


\section{IN AUSTRALIAN TROPICS}

white uniform, and the long Colt dangling at his side. He carried too many guns for his countrymen.

When on board the Pattie Dyarvaya, I had some of the tortoise-shell produced, and it turned out to be remarkably fine. In fact, Robinson said he had never seen anything to equal it during all the years he had been on the coast. The natives who procured the shell saved it all for the Malays, because they could always get spirits in payment. These proas had between them one hundred and thirty men and nineteen large canoes engaged in dredging for trepang, so some idea can be formed how thoroughly the coast was cleaned up when large numbers of proas were down, and worked, as they did, night and day. They also employed a great number of natives. All the papers on the proas were made as having cleared from Macassar for Marigi, which means blackfellow's country or unknown land.

To think such a scene was possible on the coast of Australia! There were four proas anchored close in to the beach, some sixteen large dredging canoes at work, and numerous smaller ones plying between the proas and the beach. On shore were four great smoke-houses, built of bamboo and palm-leaves. Of Malays there were about one hundred engaged at various occupations in connection with the preparation of the trepang. Some had only scant clothing, others wore their gay saarongs, and all had gaudy handkerchiefs twisted round their heads. The boxes containing the necessary ingredients, ctc., for making their 'quids' were lying round everywhere. The 'quids' were made by rolling up a piece of 


\section{CURING TREPANG}

Areca nut in a leaf smeared all over with wet lime, which was placed between the lips and left until it dissolved, the result being red expectoration and black teeth.

A large number of aborigines, men, women and children, most of them in a state of nature, were also present. The niggers were either assisting the Malay's, or lolling about smoking cigarettes made of Malay tobacco, rolled up in pandanus palm-leaf.

The appearance of one of the masters, by name Bapa Paloe, struck me greatly. He was, for a Malay, a tall, broad, well-built man, and very stately. It was a fine sight to see him stalking about among the crowd; his brilliant saarong hanging from his shoulder across his chest added to the magnificence of the man.

The scene and the various occupations greatly interested us. The pity of it was that we had no camera. And no man regretted this more than Inspector Foelsche, officer in charge of the police in the Northern Territory, for he was a most enthusiastic and successful photographer. He had left all his appliances at home, thinkink them too cumbersome to carry on a small boat. There were no kodaks about then.

The trepang, when landed, was cast into great iron boilers, boiled slightly, then cleaned, and boiled again in a tan of mangrove bark, why, I am not certain. It gave it a red appearance, whereby the wily Malay perhaps thought he could get to windward of the still more wily Chinaman, the consumer, for red fish is of far greater value than the grey, the only variety found on our coast. After the second boiling it was dried, and 


\section{IN AUSTRALIAN TROPICS}

then smoked, by which time the great slug had a very insignificant and objectionable appearance.

The Malays, who are great fishermen, always treated their lines in the boilers with the trepang. It made them beautifully smooth, and they did not kink. Being a fisherman myself, I always, when possible, obtained lines from the proas. The Malays had three methods of procuring trepang, dredging, diving, and at dead lowwater, spring-tides, using short spears on the reefs. I saw many of the men when diving, swimming of course in six and seven fathoms of water, come up with an armful of the sea-slugs. These men were often attacked by small fish. I saw several who were a mass of sores from that cause. Owing, no doubt, to the nature of their work, and their food, skin diseases, especially ringworm, appeared common amongst the crews of the proas. They didn't seem to mind. I saw one man who was evidently cook on board the proa, who, when not attending to the boiling rice, was scratching himself from head to foot, the result being a regular shower of dry skin. It struck me as rather disgusting at first, but I soon ceased noticing such little trifles.

While we were at tea, Bapa Paloe came off to the cutter to see me on business. Wishing to be nice to him, I told the boy to give him a drink of square gin to keep him going until we had finished tea. Truly he was kept going, for the idiot of a boy left B. P. the bottle, and he put away about two-thirds of the contents, which did not seem to inconvenience him in the least. When he was lcaving, I said to myself, 'B. P., we 
will meet again, and I bet I 'll be square with you,' anrl so I was, as you will hear later on.

During our stay here we had a turn at the birds in the swamps adjacent, but with poor luck, although there was any quantity of game about, for the wet scason only being just over, the swamps were full of water, and the reeds and grass a tremendous height. Our niggers managed to secure some geese, for they could crawl in and out where a white man couldn't, or at any rate would want a lot of inducement to follow suit. Another day we had a turn through genuine tropical mangrove swamp after duck. I arrived at the conclusion that for a real depressing, melancholy, heart-breaking place such a swamp comes out on top. I am almost afraid to montion the size and the density of the growth for fear I might not be believed. Just listen to the description of a mangrove swamp by a dear old chum of mine, Eneas E. Gunn, who had great experiences on the north coast, and who had a pathetic end on an inland station. For the safety station he was on, poor old Gunn had to go out and try and pot some desperate niggers. This is what he wrote: "We had not gone very far when we startled a pheasant from its noontide nap in one of the isolated clumps of trees. A vigorous series of "Poo-hoo-hoos" rang out on the still midday air. The blacks, who are almost preternaturally keen in detecting an abnormality in the natural effect surrounding them, were, doubtless, instantly on the alert, for although we waited long in the hiding the trees assured us, we had hardly commenced to move from cover when we saw several dusky 


\section{IN AUSTRALIAN TROPICS}

figures running across the salt marsh into the mangroves. We started in pursuit at a run, but when we reached the camp we found it, as we expected, deserted. The fire was still burning, and the haste in which the blackfellows had left their camp was cvidenced by the fact that they had forgotten to take with them what must have been the largest part of their weapons. Boomerangs, spears, throwing-sticks, nulahs, shields, and remnants of a halfconsumed meal of roasted boabab nuts, were lying about the place. We did not then wait to make a collection of aboriginal curiosities, but, picking up the tracks of the retreating savages, followed them into the mangroves. The successful pursuit of blackfellows in such a tangle of roots and branches was almost as hopeless of achievement as the proverbial search for a needle in a stack of hay; but the chagrin we felt over the defeat of our previous purpose fired our spirits with a relentless zeal, and, each selecting a track, we followed the diverging footmarks through the dense, dark, eerie, smelling infe no, with the instinct of sleuth-hounds. Nothing will cver obliterate from my memory the impressions that hunt made on my mind. The place seemed to be the very heart of the huge solitude in which we were situated. Overhead there was a dark, closely knitted canopy of leaves. Only here and there a patch of ineffably blue sky, that appeared to be immeasurably distant, gleamed through rifts in the firmament of foliage. Through the apertures the sun shot vertical shafts of golden light that counterfeited rilded pillars, except where their masses were brolen by contact with the trunks and limbs of the 


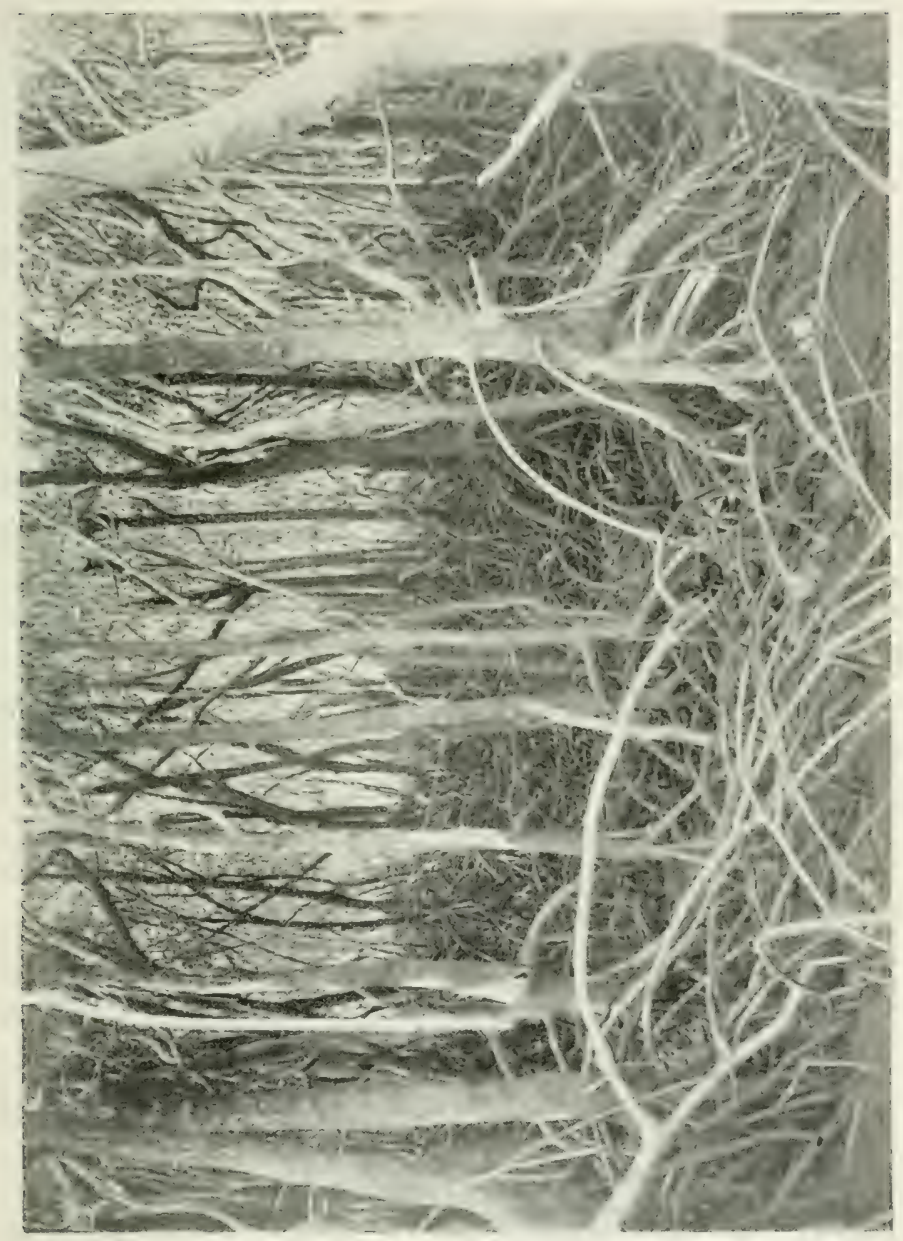

0
$\vdots$
0 



\section{A MANGROVE SWAMP}

trecs. But the lights that stole through only made the gloom more ghostly and unreal by the contrast. It was like a weird, uncanny underworld, a vast, shapcless vault, whose roof was supported by gnarled and knotted trunks, carved with fantastic devices by the processes of Nature. Slender flying buttresses vaulted away from the trunks in long series of elliptical arches. The whole scheme of design of the jungle might have been that of an unimaginable mediæval cathedral, conceived in a nightmare and executed in a delirium. It seemed to be peopled by unscen, silent, thinking, fecling bcings, capable of action, and the twisted and contorted boughs and branches, stretching out hideous, mud-stained arms, that appeared ever intent on catching and holding one in their loathsome embraces, intensificd the impression. The atmosphere was stifling, and permeated with a hot, miasmatic vapour. The silence was intense, and broken only by faint sounds of something moving forward, the gasping of shellfish that lay in the mud or clung to the roots and trunks of the mangroves. So still was it one could almost hear the moisture exuding from the ooze, or the sap coursing in the veins of the trees. But there was a track in the mud, a purpose in my heart, which did not become less insistent as every now and then on ahead I could hear a crack, the sound of a branch pushed aside, and its swishing back into place. Nothing was visible. There was no distance, no vista, no perspective, only knotted and twisted trunks, a tangle of boughs and branches and roots, of roots and branches and boughs; above, a roof of leaden leaves; underfoot, a slushy, 


\section{IN AUSTRALIAN TROPICS}

noisome ooze of decaying leaves, roots, shells, and mud.'

I often read that over and over again. It takes me right back to the tropics, and in fancy I live the old life once more.

Before our departure four more proas arrived, all from Dylompo. They were the Lambero Lakara, Mariza, master; Saroi Mason, Parockka, master; Pareresn, Parduon, master; Lambere Olpre, Tascing, master. All had numbers of pearls, which I had produced, or at any rate what they thought fit, for the serang of the cutter informed me that those forthcoming were only the inferior ones, the pearls being divided into firsts, seconds, and thirds. One of the bottles shown, for there were three pint pickle bottles, the master informed me would realise fifteen hundred rupees in Macassar. I received reliable information that a proa the previous season had taken away thirty-five catties-weight of pearls, no doubt the majority being inferior, but amongst such a quantity there were bound to be some of great value. The natives collected the pearls during the absence of the Malays, for whom they saved them, and received in exchange grog and tobacco. On all the outlying reefs at low-water pearl-shell could always be procured. Pearls were found in other descriptions of shells. I had given me a beautiful pair of shells, a sort of mussel, from which I was informed a superb flesh-coloured pearl was obtained, which was taken to Macassar and realised hundreds of pounds.

The Malay's took away immense quantities of tortoise- 


\section{TURTLE}

shell, which was also collected by the natives. The coast is infested by hawk-bill turtles, from which the article of commerce known as tortoise-shell is taken. There is also an unlimited supply of the green-back turtle, from which the famous soup is made. I have eaten the hawk-bill turtle, but the green-back is considered the proper one for edible purposes. I have scen the niggers kill the turtles, and after cutting out the meat, scoop out the rich green fat, which lies between the meat and the shell, and eat it hot and raw. The turtles come up above high-water mark and scratch out a nest in the sand, where they lay their eggs, and then cover them over. The eggs are hatched by natural heat. In the first nest I found ten dozen fresh eggs. We used them in omelettes and flips, and, in fact, did them up in all sorts of ways. If it were not for their natural enemies the sea would be teeming with turtles. After being hatched, and while on their way down to the sea, the young turtles are preyed on by birds, and then those that reach the water are set upon by fish.

Our black friends did not appear to mind if the turtle cggs were not perfectly fresh. Once on the coast we fell in with some Myall niggers who had just opened up a nest. The eggs on being broken were found to contain nice little turtles just formed. The niggers flicked out the turtle, and swallowed the residue with great gusto.

I managed to secure a magnificent specimen of tortoiseshell worth, honestly, $£ 4$. When I returned to Port Darwin I met a friend from the interior who asked me if I happened to have any tortoise-shell, as he was anxious 


\section{IN AUSTRALIAN TROPICS}

to send some south to an old man who amused himself, and managed to make a little money by the manufacture of combs and ornaments. It being, as I thought, a case of charity, I gave him my splendid shell. A year afterwards I again met my friend, and in answer to a query as to what the old man thought of the shell, he said, 'You did not think I was such a f fool as to send him that shell ; I kept it.'

Having finished our work here, we proceeded to Mount Norris Bay, to have a turn at the buffalo. It was early morning when we landed on a beautiful beach, at the back of which was a narrow swamp, with a belt of jungle beyond. Having crossed the swamp and entered the jungle, I caught first sight of a buffalo-a bull-calmly feeding, he not having heard us approach. However, he quickly realised that there was something dangerous about, for he was off like a flash. A shot, bloodstains on the grass, and that was all the satisfaction we obtained. Our bad luck followed us. The grass, which was something like eight feet high, was much against us. We could hear the beasts, but could not see them. We managed to wound two or three, one of which turned on Robinson, but another shot made him change his mind, and he disappeared in the long grass. We were in despair, when on the second day Robinson managed to hit a bull hard. The country at the spot being fairly clear, we followed him up quickly, and I put a bullet through his head. It was a splendid animal, and we soon had the crew at work, so in about two hours the carcass was cut up and on board. We must have walked during the 


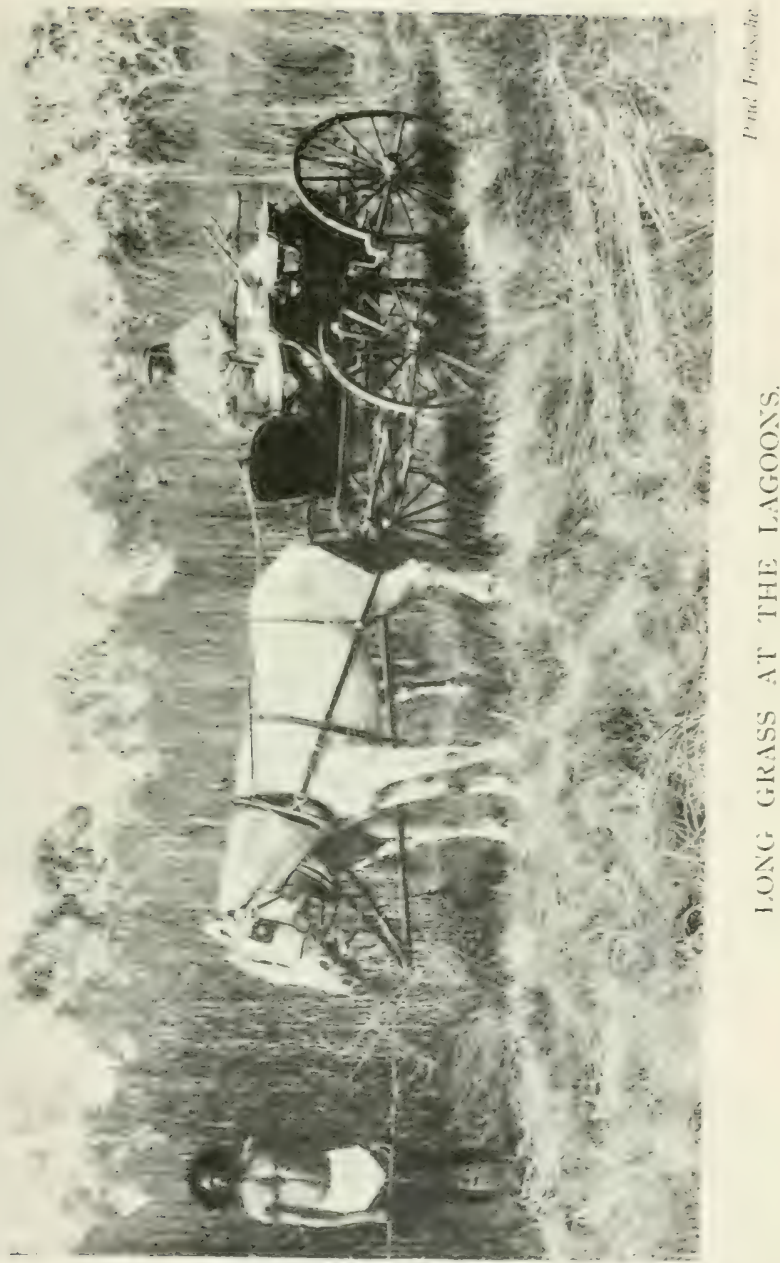





\section{SHOOTING BUFFALO}

two days fully forty miles. It was hard work having to carry rifle, ammunition, and revolver. The revolver did not seem much to carry at the start, but when the excitement was over I thought my left hip was broken, the weight of the shooting-iron having been there all the time. It must be remembered that the niggers on the coast were not to be trusted, so that it behoved us to be well armed. We had some of the Port Essington boys with us-all in a state of nature, clothes on the coast being an unknown quantity-otherwise we might have had considerable difficulty in making our way back. At any rate, I should have been properly bushed.

A native in a strange country does not so much look ahead as he does over either shoulder, for, as a rule, if you are to get a spear, it is from behind.

A small island, Copeland, close to where we were anchored, was alive with quail, but unfortunately I had no cartridges.

Having had our turn at buffalo, we sailed for Port Essington, where we found three more proas, the Lambere Kaledeofa, Winda, master; Todjecng Kanaya, Ardang, master; Boxding Manonkokie, Lamoeda, master, all from Dylompo. Having visited the proas we went on shore to the smoke-houses. Several of the niggers were drunk, and had just finished a fight, one having had his head split open. The liquor the Malays carried was awful stuff. At different times, when out of grog, I tried it under all sorts of disguises, but it was no go. From my experience niggers can carry a fair amount of good liquor, but this stuff seemed to send them mad. I 


\section{IN AUSTRALIAN TROPICS}

invariably gave my boys a nip or two a day when hunting, although, of course, it was against the law. I remember two of the Port Essington boys calling at my quarters at Port Darwin. I offered one of them a drink, saying, 'Moyout, you must not tell Mr. Foelsche,' by way of a joke. He replied, 'Do you think me a fool, captain ?' The other one, on being invited to imbibe, said, 'No, thanks, Mr. Searcy, I don't drink.' These boys spoke good English, Macassar, and, of course, their own language. That is a good indication of their intelligence. I might mention that all the coast niggers to the eastward, from their long association with the Nalays, spoke Macassar, therefore I always took Port Essington boys with me on my subsequent trips, so as to make friends with the Myalls-the wild natives.

It appeared to me from my short experience of the aborigines of the north coast, and my first impressions were confirmed by future dealings with them, that they were far and away superior, both in physique and intelligence, to the natives down south. It must be remembered that the food-supply available for the niggers on the north coast was unlimited. All the rivers and swamps were teeming with game and fish, also alligators, of which the blacks are very fond. In the swamps and jungles edible roots are always obtainable, while on the coast, shellfish, dugong, and turtle abound. This, taken in conjunction with their long association with the Malays, may be the explanation of the superior type of the aborigines of the north coast of Australia. In I)arwin we had a couple of instances of marvellous 
intelligence displayed by two natives, such quickenin:s of the faculties no doubt in a measure being due to the fact that they were minus certain senses, both being afflicted. The first was known as 'Blind Solomon; an old man who, in his childhood, lost his eyesight through smallpox, it is supposed. The marks on his face showed that at one time he had been a victim of that dread disease, which was introduced by the Malays, and which at times swept right across the continent. Solomon was blind before ever white men settled on the north coast, consequently he had never had a chance of secing the lay of the streets in the town. Yet he was employed in delivering parcels and messages, which he could be absolutely relied upon to do. He simply would feel his way about with his wommera or throwing-stick. He could always recognise people by their footsteps, and once having heard a voice always remembered it. Old Sol used to get a lot of money from people passing through Darwin. A coin would be thrown on the ground, and he would have to find it. As he drew near, the cry would be 'Cold, Solomon,' and when far away, 'Warm.' I think the old man saw through the joke, for when he had amused the people for some time, he would say, 'Oh, you too muchee gammon.' He always got the money. His great delight was to stand outside one of the banks, and listen to the counting of coin. The bank people at these times got very mad, for he would laugh and yell. 'O Mr. —, my word too muchee money!'

The other nigger was known as Dummy. He was deaf and dumb, and had always been so. He was em- 


\section{IN AUSTRALIAN TROPICS}

ployed in a store, and could do his work with the best of the men engaged. Dummy was also utilised for delivering parcels and messages. The boss workman, a Chinaman, was always the man who gave him instructions as to where and to whom he should go, by indicating some peculiarity in the person. He often used to come to me at the Custom-house, but I never discovered my particular idiosyncrasy.

To see the sign language used by the other natives when conversing with Dummy was vastly entertaining. Often the poor chap would burst out laughing, as if some funny story were being related, which I dare say was the case, at the expense of some European, for the nigger is very observant.

The boys at Port Essington were remarkably polite when out hunting, when possible, holding back the branches of the trees and undergrowth and grass. Often, when I wanted a drink of water, one of them would get a leaf from some adjacent bush, twist it in a spiral shape, fill it with water, and bring it to me.

During our stay at Port Essington we had another turn at the buffalo. We crossed the harbour at daybreak, passing over the coral reefs, on which trepang could be plainly seen, and where a number of Malays were walking about picking up the slugss with their short spears.

We had no luck the earlier part of the day. During a trudge of some twelve miles we frequently saw fresh pads and tracks, but only heard two beasts. However, we could not stay with them, or keep the dogs going, on 


\section{COLD SQUALLS}

account of the grass which towered over our heads. Fresh pads and tracks, although frequently seen, were no sure sign that the animals were numerous, for one beast wandering about, as is the habit of the buffalo, can give a lot of indications in that way.

There had been a heavy dew during the night, so, as can be understood, it was not long before we were wet through: not that there was much to wet. After a spell, at midday, we had better luck, knocking over a cow and calf. It is doubtful if we should have secured the former if the calf had not been shot.

While at work on the carcass of the cow a heavy rain squall from the south-east came up. So we soon felt sort of frozen. A large fire was quickly blazing away, slices of liver were placed on the coals, and we managed to make ourselves comfortable inside and out. All we had had in the way of tucker was a handful of cold rice.

When near the sea I have many times been caught by fierce, driving, freezing squalls; on these occasions I used to sit in the salt water up to my neck to keep warm.

During the heaviest of rains, if there are paper bark trees about, a fire can always be made. The bark can be peeled off in thin flakes, as its name suggests. The inside is perfectly dry, and makes splendid kindling.

Having some of the crew, besides the niggers, with us, the carcasses were soon cut up for transport. I carried the tongue, brains, and the calf's head, and so started for the cutter, some six miles away, a lively tramp through mud, water, and the long wet grass. It was raining at the time. 


\section{IN AUSTRALIAN TROPICS}

Once on board, a nip, dry clothes, and then an attack on a big dish of fried brains (I can recommend fried buffalo brains), after which the pipe made us feel at peace with the world.

Although our luck had been a bit out, we had had good fun, and I saw a great deal of the country. In open country, or in the dry season, we should have had a far bigger bag, for Robinson was a splendid shot; but what could be expected when sound only was our guide?

Of course, having guests, Robinson wore a certain quantity of clothing, but nary boots or socks. That made no difference, however, for over the sticks and stones, through the grass and undergrowth, he went without the least inconvenience.

I dare say there are comparatively few people who are aware that we have such big game as buffalo on the north coast. Of course, they are not indigenous to the country, but are the offspring of those left by the soldiers when the old settlements were abandoned. Only a few beasts were left, but it is simply marvellous how they have increased. Shooting buffalo for their hides was only carried on in a very small way during the first few years I was in Port Darwin, but it suddenly became a regular industry. The records of the Customhouse afford proof of that, for during a little over ten years nearly fifty thousand hides were exported. The buffalo on the mainland spread wonderfully. As the herds multiplied, the old bulls were driven out and wandered great distances. I saw their tracks on the Roper; 
I heard of them on the M'Arthur; and some of the backblockers informed me they had been seen in Queensland. Just before I left Darwin the keeper at Port Charles Lighthouse shot an old bull which turned up here one night, fancying, I suppose, he had at last reached a haven of rest.

Only on one occasion did we have a buffalo turn on us, but before he came too close a bullet reminded him of an engagement elsewhere. The hunters, and the niggers with them, have at times experienced some nasty falls with the buffaloes, and in several instances they have been gored. Some miraculous escapes have occurred. When the hunters have been down, and the beasts have been trying to get at them with their horns, they have crept out, and catching hold of the horns, have vaulted over the backs of the animals and escaped. The possibility of this can be realised when one understands the size of the horns. I have a pair just six feet across, and I have seen a pair measure nine feet. I was never lucky enough to have a turn at hunting on horseback, which became the fashion when shooting developed into an industry.

Some of the animals having such tremendous horns, it is marvellous how they manage to get through the bush and grass. However, when running, they poke their noses straight out, which has the effect of laying the horns well down the back, where they offer least impediment.

The buffalo, though bulky beasts, are most active on their pins. I know they are, through having been in front of them, but on such occasions I lost no time in 


\section{IN AUSTRALIAN TROPICS}

getting to the rear. When the animals are feeding, the horns have a wicked look.

One of the shooters, Paddy Cahill, had a splendidly trained horse which he used in his hunting; in fact, the equine pretty well did the work. As soon as a mob of buffaloes were sighted, the horse, as a matter of course, galloped alongside while his master attended to his particular part of the game. Forty-five in one day is, I think, sufficient proof that rider and horse understood the business thoroughly. When the shooting for the day was finished, the horse of its own accord would proceed to each carcass and stand there until the skinning operations were finished. The master of the craft trading between the buffalo-shooters and Darwin went with the hunters one day to have a look at the fun. So surprised was he at the performance of the horse, that he said, 'Say, Paddy, why don't you give the blanky horse a knife and let him skin the blanky beasts?' Another accomplishment of the horse was the manner in which he would, at a word from his master, chase objectionable niggers out of the camp. You may be sure the niggers respected that animal.

What would be thought of feeding horses on geese eggs? Such was the case, however, when a party of buffalo-hunters were stuck up on the Adelaide during the wet season. The niggers used to bring in canoe loads of the eggs, which were broken into buckets and supplied to the horses.

Before the advent of the horse for hunting, I have known a buffalo-shooter on foot, when he struck a good 


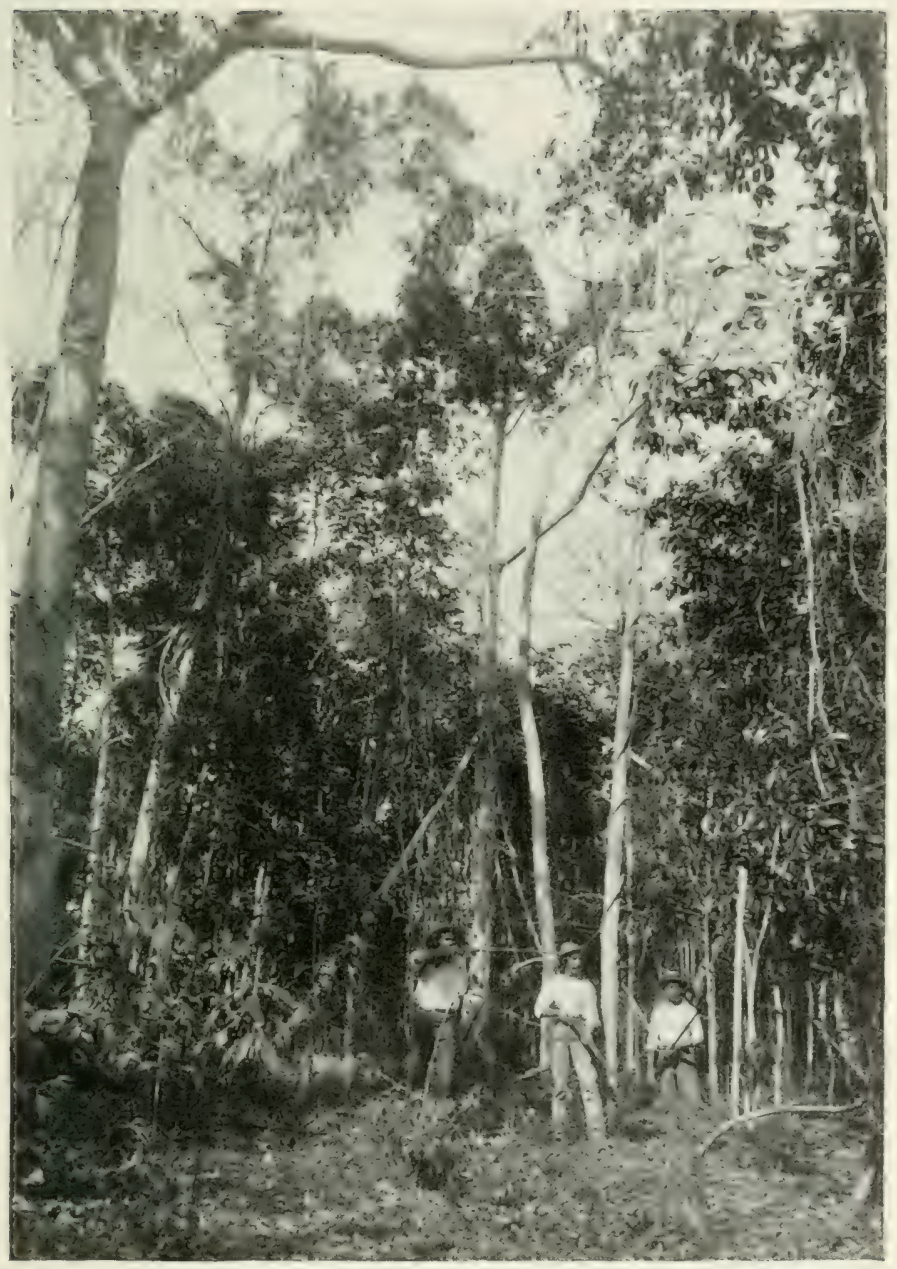

IN THE JUNGLE.

H. II. Christie. 

mob, run alongside of the beasts and bowl over seven before they got away.

Some slight effort, I believe, was made to tame and utilise the animals, but no good ever came of it. At Port Essington they had about a dozen fairly tame ones, which were herded during the day by an old lubra, and yarded at night. You may be sure a strong yard was needed, for if a buffalo makes up its mind to shift, something has to go. I believe these beasts eventually wandered away. Some years before, a strong yard was erected, and a lot of buffalo were run in. It appeared that no provision was made to give the animals a drink, so it was determined to drive them to water. The yard was opened, and that was the last ever seen of these beasts. The driving experiment was a miserable failure, confidence misplaced. A yarn used to be told-I cannot vouch for the truth of the statement, but I will give it as I have heard it. A man managed to get a team of buffalo to Southport, and in due time they were hitched to a dray. A start was made, and that was the last ever seen of the man, buffalo, or dray.

Having taken on board a small canoe I had procured from one of the proas to send south, also many dozens of rock oysters, for which Port Essington is famous, we sailed for home, reaching there in three days. So ended my first trip at proa-hunting. 


\section{II A P T ER IV}

THE SECOND VOYAGE IN TIHE 'FLYING CLOUD'

BY the time the nor'-west monsoon might be expected the Malay proas had worked their way down from Macassar as far as Kissa, an island near Timor, and about five hundred miles from our coast. There they filled up with water, cocoa-nuts, and material necessary for the erection of the smoke-houses used in the curing of the sea-slug. In fact, this was the last port of call. As these extraordinary vessels are only good before the wind, it was necessary that the Malays should be certain that the monsoon had set in properly before making a start. The wind, however, has been known to fail them during the voyage, and terrible hardships have been undergone before the nor'-wester made again.

To give an idea of the awful calamities which sometimes befall those who man the proas, I cannot do better than quote from Frank Bullen's The Cruise of the Chacalot. 'One morning, a week after we had taken our departure from the Seychelles, the officer at the main crow's nest reported a vessel of some sort about five miles windwarc. Something strange in her appearance made the skipper haul up to intercept her. As we drew nearer we made her out to be a Malay "prahu"; but, by the 


\section{MALAY PROAS}

looli of her, she was deserted. The big three-cornered sail that had been set hung in tattered festoons from the long slender yard, which, without any gear to steady it, swung heavily to and fro as the vesscl rolled to the long sweil.

"We drew closer and closer, but no sign of life was visible on board, so that the captain ordered a boat to go and investigate. In two minutes we were speeding away towards her, and, making a sweep round her stern, prepared to board her. But we were met by a stench so awful that Mr. Count would not proceed, and at once returned to the ship. The boat was quickly hoisted again, and the ship manceuvred to pass close to windward of the derelict. Then, from our mast-head, a horrible sight became visible. Lying about the weatherbeaten deck, in various postures, were thirteen corpses all far advanced in decay, which horrible fact fully accounted for the intolerable stench that had driven us away. It is, perhaps, hardly necessary to say that we promptly hauled our wind, and placed a good distance between us and that awful load of death as soon as possible. Poor wretches! What terrible calamity had befallen them we could not guess; whatever it was, it had been complete; nor would any sane man falling across them run the risk of closer examination into details than we had done. It was a great pity that we were not able to sink the prahu with her ghastly cargo, and so free the air from that poisonous foetor that was a deadly danger to any vessel getting under her lee.'

As a rule, proas sighted Melville Island first, and then worked their way down the coast to the eastward, some 


\section{IN AUSTRALIAN TROPICS}

proceeding as far as the Gulf of Carpentaria. Apparently the Malays never succeeded in making friends with the natives on the island. That the Malays at some time had started work on the north side of the island was evident, for remains of old fireplaces and smoke-houses have been found there. Major Campbell, who was Commandant at Fort Dundas in $\mathbf{1} 826$, conjectured that the reason why the blacks were so suspicious of strangers was that the island had been previously visited by Malay slavers, who had carried away some of the aborigines as slaves. The Malay fishermen were forbidden by their owners to go near Melville Island (which they called Amba, the Malay word for slave), alleging that it was infested by pirates. On one occasion Major Campbell noticed a Malay boy with the blacks. At such times as the buffalo-shooters on the island managed to come to friendly terms with the niggers, it was noticed that although their language was totally different from any on the mainland, they used the same words for 'white man' - 'monkey jarra,' which is a Macassar expression. No doubt many proas have been wrecked there and the crews massacred by the wild inhabitants. To our own knowledge, two proas were cast away there during one season. The crew of the first, the Erang Polia, was attacked, and but for the plucky action of the master, a determined old man, named Oesing, things would have been serious, but he kept the niggers at bay with an old carbine while four canoes were launched and fitted out. The crew succeeded in reaching the revenue station after undergoing terrible hardships. A similar reception met the crew of the other 
proa, Lasalasay'a, but they only succeeded in getting two canoes afloat, in which twenty-seven men were packed. When they reached the station they were starving, During the voyage they passed a dead Malay in the sea, and as there was a proa missing, this pointed to the fact that she must have foundered. On another occasion the crew of a wrecked proa had to defend themselves for several days. They eventually got away, after the loss of one Malay and two black boys from the mainland, who had been to Macassar with them. Two or three others were wounded. During our time many proas have been known to have been wrecked in the Gulf of Carpentaria with loss of life, the survivors having worked their way along the coast to the camping-place of some comrade. So it will be seen that the Malays, like others who 'go down to the sea in ships,' suffer great hardships. Considering their primitive vessels and appliances, it is marvellous they do not experience even greater privations.

We generally expected the proas down about Christmas, and so as to be in time to meet them, I left Port Darwin in the Flying Cloud at the end of November I883, accompanied by another officer, Mr. H. Pinder. After six days' battling with head-winds and strong tides, we arrived at Port Essington. During the voyage we sighted scveral waterspouts. When off Cape Don, just at dusk one evening, a steamer coming from Port Darwin hove in sight, and, knowing that many of our friends were on board bound south for a spell, as she passed us we saluted her by firing our carbines and sending up a rocket, a most improper thing to do. The steamer 
answered with a flash-light. All would have been well if we had been satisfied with our first display, but we continued our rocket-firing, which was idiotic. The master of the steamer thought we were in difficulties, as we were close in to the mainland shore, so he hove to. Our old man then saw what a howling mess we had made of things, so used certain language which he was not in the habit of doing. Feeling very small, there was nothing for it but to stand out and show that all was well. This we did, passing astern of the steamer. The delay caused the vessel to lose a night at Thursday Island. When I met the master of the steamer, the Tannadice, Captain S. G. Green, afterwards, he expressed several strong and sanguinary opinions, but wound up by saying, 'I would not have cared a d- if you had come on board and had a drink.' When there was no wind and the tide had turned against us, the kedge, if it were possible, was dropped to prevent the cutter being driven back. On one occasion we anchored in twenty-nine fathoms. On another occasion, to save being driven back, we dropped the kedge in nineteen fathoms off Cape Don, where the tide rushes at a terrific rate, and if the wind should be against the tide, a fearful rip is the result. The old man stood at the helm for six hours to prevent her breaking her sheer, thus obviating a sudden strain on the line with the chance of parting it. At this spot the bottom is very foul, as we found, for our anchor caught in some rocks. We carried away the winch trying to heave it up, so had finally to cut the anchor line.

Ilaving had a day's spell ashore, we were under way 
again, Robinson having joincd us. Our idea was to pay a visit to the local trepang camp at Trepang Bay. When round Vashon Head and running into the bay, everybody intently gazing shorewards to pick up the camp, the serang, who was in the rigging, happened to glance down and yelled out 'Batu, Batu,' meaning rocks, rocks. The old man rushed to the side, but it was too late, for up we went on to a reef with a rattle. Luckily the breeze was not strong, and there was very little sea. As we could not kedge her off, a large portion of her stores were landed in case of accident. Our grounding necessitated a four-mile walk through sand to the camp. The heat was terrific and the flies beyond description. A large number of natives were camped with the trepangers, but, on catching sight of us, they disappeared into the bush like magic. After some trouble the niggers were persuaded to return, and a dole of tobacco was served out to them. I always carried tobacco to assist in establishing friendly relations with the blacks. It was not far from here that sometime afterwards the beautiful and world-wide known yacht, the Red Gauntlet, was wrecked. The sailing-master, who had been navigating officer on board a big ocean liner, did not seem to think much of taking bearings or running on his dead reckoning. He was bound from Malay Bay to Darwin, and, although having the coast abeam all the time, fixed his position by shooting the stars. He swore the coast was three miles out. At any rate the yacht found it. An Imperial vessel had to do some surveying work there sometime afterwards, and found that the coast had re- 


\section{IN AUSTRALIAN TROPICS}

turned to its original position as shown on the chart. When the sailing-master met the owner (the late Mr. C. G. Millar) for the first time after the wreck, he was saluted by 'Look here, too much — science has lost me my yacht.' The wreck soon disappeared. Everything of value went to Macassar in the proas. The Malays were excellent scavengers.

After our terribly hot walk it was a treat to get on board again and discuss cold beer. Our old man, who was a staunch teetotaller, was invited to join us, so that he could take the fact of his vessel being ashore more philosophically. With strong words he informed us that the chance of the Flying Cloud being lost would not drive him to drink. At high-water that evening we came off, and the stores were reshipped. The cutter having to take stores to some Chinese timber cutters at Bowen Straits, we decided to leave her outside the Heads, and in the dinghy proceeded to Robinson's camp, at Vittoria, a distance of twenty miles. In the boat were Robinson, Pinder, myself, and three niggers. All went well at first, for we had a nice little fair breeze, then the wind chopped right round to the south-east, slap in our teeth, and it blew savagely and raised a nasty sea. There was nothing for it but to lay our ears back and pull, and a nice doing we had. To make things more cheerful we found that one of our oars was badly sprung. So we had to use it tenderly. At last we managed to make Point Smith, the eastern side of the entrance to the port, and landed for a well-descrved rest, and with upwards of fifteen miles yet to pull. To our great disgust we found that the tin 
of meat we had with us was not cdible. So it was a case of drinking water and looking happy. At ten o'clock at night we reached Robinson's camp, fairly famished; but Robinson's eggs, bacon, and bottled beer also looked famished by the time we felt ourselves again.

The entry in my diary for the following day was: 'December roth.-Lay back and took it out in slecp.'

Pinder and I decided that, until absolutely necessary, we would camp ashore, so made ourselves as comfortable as possible in a small open shed on the beach.

The Flying Cloud was a capital sea-boat, but as a residence for a lengthened period she had drawbacks, for she was chock-a-block with cockroaches and rats. Many means were tried to get rid of the pests, even to pumping the old Cloud full of water, but the vermin were soon as bad as ever. You are aware, no doubt, that the tropical cockroaches grow to a great size, and are full of business. An immense fellow sailed into my room at our quarters one night, and on examining it, I found a great number of tick fastened upon the stomach portion of its body. You may have heard that these insects have a great predilection for finger- and toe-nails. When in the Cloud asleep I had my toe-nails nibbled right down to the quick. The rats on board were beastly familiar. They often made one's body the means of reaching the deck as quickly as possible. I woke up one night and found a great brute seated on my face. The old skipper was death on cockroaches by means of a round piece of leather on the end of a pliant stick. When he was in his little cabin you could hear the 
flop as regular as clockwork. He flopped to some purpose, for he became a dead shot.

I have mentioned that Port Essington was once a military settlement, and that the ruins of the buildings erected during that time were still standing. Neither 'ivy clad' nor 'crumbling with decay' of ages, the ruins looked more as if dismantled by the hands of men than by Father Time, and I believe such was the case. The masonry was of a very substantial character; the magazine was still perfect, as also the brick kiln and stone ends of the men's quarters. A tremendous lot of work had been done by the soldiers in the olden days. Many of the posts of the fences were still standing, and the timber in the old jetty was as sound as ever. A short distance inland was the old burial-ground, nearly hidden by dense tropical growth. There were several headstones still standing and one large monument. I think the latter was in memory of a sergeant of marines. Many an hour I spent in looking over the old spots. About half a mile from the camp was a spring, the water being deliciously clear and pure. It was always used at the camp for drinking purposes. There was a water-hole attached to the spring, which was enfolded in a perfect arbour of tropical vegetation, and was reached by a pretty grassy bank on which grew numbers of fine mango-trees. Some of these were bearing, but with such large numbers of niggers about there was little chance of getting any ripe fruit. At one time, near the camp, there used to be some magnificent mango-trees, I expect planted by the scttlers, from which tons of fruit were taken to Darwin; 


\section{GEESE AND PIGEONS}

but what with white ants and the efforts to get the better of the pests, the trees died.

Being the end of the dry season, of course nearly all the grass was down, and in most places burnt, so we had no difficulty in getting about. In the swamps adjacent, ducks and geese were very numerous, and we had plenty of fun in shooting them. Along the edge of the bamboo jungle and in the Casuarina trees on the shore, a very large dove was procurable in considerable numbers, and splendid eating these birds were. Another bird, the squatter pigeon, also afforded good sport. Often when strolling along in the bush, at your very feet there would proceed a flash and a whir, and a fine pigeon would settle on the top of a high tree. The bird was something worth having when bagged. That the niggers are marvellous climbers I had a good illustration one day. When shooting geese, several lodged in the branches of some very tall, straight, smooth trees. The niggers were up in a moment, with the soles of their feet on the stem of the tree and their hands clasping the same. To them it seemed as simple as falling off a $\log$.

Being desirous of seeing something of the country on the other side of the harbour, one morning at daybreak we pulled across. The tide being out necessitated a long wade over coral and stones, a nice preliminary to a several hours' tramp. Trepang appeared to be very plentiful. We eventually came out on a small sandy beach, from which the ground rose in a gentle slope, and was covered with short green grass and some very 


\section{IN AUSTRALIAN TROPICS}

fine trees. It had the appearance of a beautiful park, and one almost expected to see an ugly board stuck. up warning off trespassers, or notifying that spring-guns were promiscuously placed around. As if in keeping with the scene, through the vistas of the foliage, we saw twenty or thirty wild ponies, quietly grazing, unsuspicious of danger, looking as if only kept to add another thing of beauty to the sylvan scene which surrounded them. Creeping cautiously, we managed to get pretty close to them. They seemed to be of a fine stamp and in excellent condition. Suddealy they saw us, and immediately the peaceful scene was changed. Snorting and terrified they rounded up, gazed at us for a few seconds, and then with a wild stampede galloped from our sight. I do not think: that any organised effort was ever made to run the ponies in. I can only remember one instance when a young mare was run down and brought to Darwin. This was done by the buffalohunter named Paddy Cahill. Several had been secured by being shot through the neck. These wounds quickly healed. The ponies, like the buffalo, were the descendants of those left: by the old settlers. Adjacent were many tracks of buffalo, but we did not sight any. After a long walk though forest country, portions of which seemed eminently suited for agriculture, we came out on the beach again. Iiecling a vacuum, we soon had the boys at work collecting oysters, which, by way of a change, we roasted on the coals with some large crabs. The only water available was thick and quite undrinkable, the buffaloes having recently rolled in it 
so we had to be satisfied with square gin from the 'baby. I guess that was the toughest feed of oysters I ever indulged in, but I am still alive to tell the tale. During our walk we saw several bower birds' nests, and playgrounds strewn with white shells, with which the birds play ornithological lawn tennis or croquet-at least so the naturalists say.

We often amused the niggers by giving them a display of rifle and revolver shooting, always taking the precaution when a really good shot was made, which does eventuate at times, either by design or accident, to cease the practice. The aborigines in their turn would get up a display of spear-throwing. Two descriptions of spears were used-one a light sort, five feet long, made of reed and tipped with hardened wood, which with the wommera they could throw some two hundred and fifty yards with great precision; the other, which was generally used when some killing had to be done, was about nine feet long, made of bamboo or wood, with one, two, or three barbed points. The wommeras, or throwing-sticks, principally used at Port Essington-in fact, on no other portion of the coast have I seen similar ones-were beautifully made out of some pliant wood, four or five feet long, for all the world like a curved sword-blade, and about the same thickness. You hardly ever saw a nigger without one in his hand, and by a peculiar turn of the wrist he would give it a flick, and a sound would emanate like the crack of a stock-whip. The best displays were in connection with the throwing of the heavy spears at arother 
native standing some thirty or forty yards' distance from the thrower. The business end of the weapon was wrapped up in mud and bark to prevent damage. Of course the boy was supposed to dodge the spear, which, as a rule, he did, displaying wonderful activity and quickness of sight; but now and then the thrower would get one in, to the great disgust of the human target. The onlookers always thoroughly enjoyed this part of the fun.

In the cool of the early morning, the most charming part of the day it always seemed to me, with the banana birds just commencing their song, I used to wander out with my hands full of fruit as a 'fair start.' This was completed by a cup of coffee, with an egg beaten up in it. I think the expression of 'fair start' is very good. The first time I heard it used in this connection was at Port Essington, when camped with my comrades Robinson and Pinder. Robinson would turn out of his shanty first thing in the morning and yell for us fellows to partake of a 'fair start.' He always had a quart bottle in his hand, which he shook vigorously. It contained fresh eggs, and the shaking was a substitute for beating. Our 'fair start' consisted of rum, about thrce fingers, the glass being filled up with shaken egg, and excellent it was. Always avoid knocking about in the tropics in the early morning on an empty stomach.

I might mention how we used to beat up our eggs when we had no swizzle stick or fork. The eggs were broken into a glass, cup, or pannican, as the case misht be. This was covered with a piece of paper, and a cluth 


\section{A SHOWER-BATH}

thrown over the vessel. We would take two or three turns with the cloth under the glass and shake for a few moments. The result is equal to any patent beater, and silent at that. Take care you don't twist the cloth too tightly, or you may break things, for the twist is a powerful purchase. I remember once when out with a comrade shooting we struck a Chinese garden, and having something in the 'baby' we negotiated with the Celestial for the other necessary ingredients to make a 'corpse reviver,' it being too late for a 'fair start.' John supplied a tin pannican, some eggs, and, after a lot of searching, some old Chinese accounts. With these and my handkerchief I did the deed. It was a great success. The Chinaman watched our proceedings with great interest, and I am sure if he tried the same dodge with some samshu or cockroach gin he must have found it a decided improvement.

Robinson had a shower-bath, of which the camp generally was very proud. Picture an old beer barrel in the rafters of a small hut, a brass beer tap, and attached to the tap a 2-lb. boullie tin with several holes. After turning the tap on you sat down, for otherwise one might get tired, and waited. It became a fine art to dodge the drops so that they should not all land on one part of the body. It was a great comfort, however, and filling the barrel amused the niggers.

I must tell you about an ancient black lady, called 'Flash Poll,' I met, who took me under her wing and professed the greatest regard for me. I expect grog and tobacco had a lot to do with her affection. This 
dame was a young woman when the soldiers were stationed at Port Essington, and a fine woman she must have been, judging from her appearance even when I saw her. Many a good yarn I had with her about the old days, and some funny stories she told. The old woman remembered the officers well, particularly the chaplain. Poll could still repeat like a parrot a prayer and sing a psalm; but I am bound to say singing was not her strong point. She had a great command of a certain sort of language, which she did not hesitate to use when her liver, for instance, was out of order. As sure as she said the prayer and sang the psalm, she wound up with 'Give it tobacco, give it nobbler,' both of which she got at times. Whenever I said good-bye, Poll always rattled off a list of things she wanted. They would have fitted out a decent bush shanty. Once a year I did send her Turkey-red, tobaccopipes, and a bottle of medicine of a sort. Flash Poll thought a lot of me; in fact, she promised me her skull; but I am afraid that interesting relic will never come my way. Her pet way of showing her grief at my departure was to ask for a knife to cut her head. Poll was a great hand at making hats out of leaves of a palm-tree. The amount of work in one was enormous, and generally occupied six months. I have to this day one of the hats that Poll made.

Naturally, some of the aborigines showed unmistakable signs of having Malay blood, in the way of a lighter skin and sharper and more refined features. In some of the women it was very marked. I remember one, 


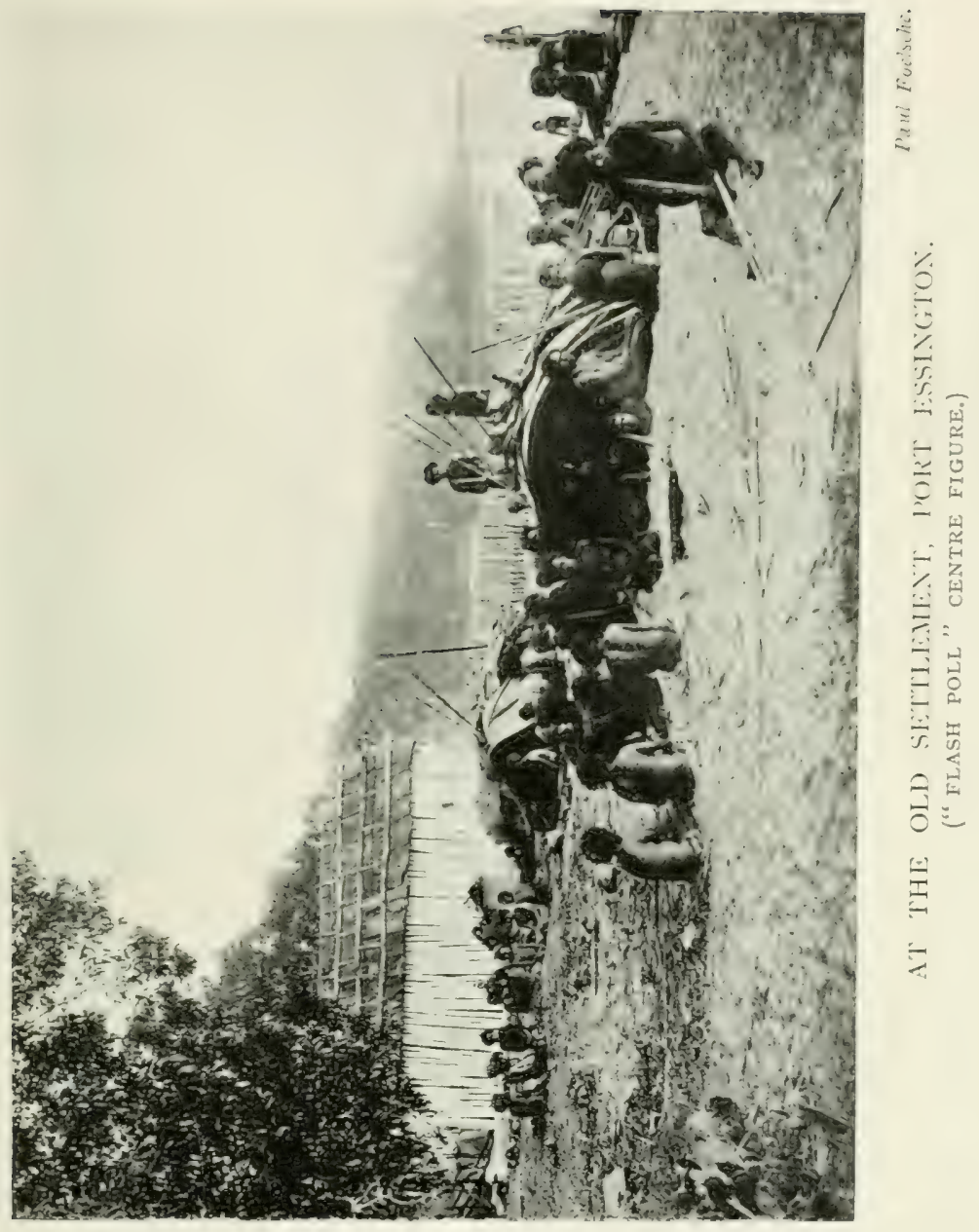



a really beautiful girl, camped at Port Essington, named Maryanagenee. She would have made the heroine of one of Louis Becke's stories, wherein that writer deals with the love of the white man for the brown woman.

At last the signs of the coming nor'wester, banking clouds, flying scud, and terrific squalls with tremendous rain, were evident. Then it came, and blew great guns for several days. At the first lull we got under way, and proceeded to Knocker Bay, just inside the Heads, so as to be ready for the proas if they should turn up. Taking advantage of the opportunity, we had a turn at the English cattle on Vashon Head, also the descendants of animals left by the soldiers.

After dinner one day we went ashore with rifles (three), but unfortunately only took a few cartridgres. Everything in the shape of weight is a consideration when you have to carry revolver, etc., and have the chance of a good run. We landed on a nice sandy beach, engirt with beautiful foliage right to the edge of the water. We walked through some pretty country, in which we saw large numbers of squatter pigeons, but as we had no fowling-piece, sighting them had to content us. Some of the jungle scenery is very beautiful, the banyans and creepers growing in especial luxuriance, the bright and delicate leaves of the latter affording a pleasing contrast to the dark evergreen of the foliage with which they intermingle. And there is another pet plant, known as the 'Waitawhile' or 'Bush Lawyer,' both very appropriate names, for the pedestrian who 


\section{IN AUSTRALIAN TROPICS}

gets embraced by the plant will find it pay to wait a while, and no lawyer's grip on a rich client is more tenacious than the grasp of the exasperating thorns, which seldom leave their victims without some signs of the encounter, such as torn clothes or scratches. After a walk of about six miles we heard cattle lowing, and following up, soon spotted a beast. Robinson crawled up ahead of us, fired, and the beast fell. I then rose, fired, and struck. The beast then made off, and we lost it in the jungle after a fair run. We saw some nice cattle, struck another, but could not run it down, being pumped. Robinson then sighted two fine bulls about two hundred yards off; he fired, and broke the leg of one. He ran up to the animal and fired his last cartridge, but missed, being winded and all of a tremble. We then tried to settle him with revolvers, but it was no good, as he went for us all in turn, running like a greyhound. The bull gave me a run after I fired a shot at him, and he would not have had far to go, as I was thoroughly tired. The beast was close up when I got a turn round a tree. Pinder then came in for his share of the fun. He got a shot at the bull, and the latter then went for him. I don't think Pinder ever travelled faster in his life, and the bull was only about three feet away from the biped when the latter turned round a tree. We could not help laughing to see them both go, but were awfully thankful when the bull gave Pinder rest. It was nearly dark, and being several miles from the boat, we had to leave the bull and start for home. The poor beast was awfully game. We got back to the Flying Cloud pretty well 


\section{WILD CATTLE}

done up after our good twelve miles' walk, not to mention the little spurts with bulls.

Next day, not feeling much inclined to do a long tramp, we sent three of the crew ashore with rifles and cartridges to finish the wounded animal. They had a great regard for this bull, for no sooner was he sighted than they climbed into a tree, and from that point of vantage blazed away all the ammunition, evidently not making the least impression on the animal. They did not look proud when they came on board. So we had to land again, which we did, and in a different spot. This was a charming place, but at the back we struck a great paper bark swamp, so had to do a lot of hard travelling through water, mud, dry roads, and grasses. In due course we reached the scene of action, and soon finished our game. The bull proved to be a fine beast of the Durham breed. At Vashon Head these cattle had been running for forty years. Considering the circumstances, it was wonderful how little they had deteriorated, and it spoke volumes for the suitability of the pastures and the excellence of the country generally for cattle-breeding. Having plenty of hands we soon had the carcass cut up, and after another hard struggle by land and sea, it was taken on board. The brains proved excellent.

We had another turn at the cattle, but it proved an awful frost. Being intent on cattle, we did not go for the two or three buffalo we sighted. Suddenly we realised that two English bulls were coming towards us, evidently to investigate matters.

A misunderstanding 


\section{IN AUSTRALIAN TROPICS}

lost them, each of us waiting for the others to fire. The animals quickly scented danger, and disappeared into the heavy timber. Words were not strong enough to express our feelings. We saw no more that day. It being necessary to sustain the inner man, and having no tucker, we cut down a cabbage palm and fed off the heart of the top and wild honey, one of our boys having discovered a large nest in an adjacent tree. When on our way to the beach I suddenly saw the boy in front nearly disappear in the air. His tomahawk came down like a flash, and he followed soon afterwards. Before he reached terra firma we found out what was the matter, for he called, 'Look out, him bite, you dead,' and just in front of us was a large venomous snake. The reptile died. When we reached the shore, one of the boat's crew, a Malay, was in a terrible state of excitement, yelling that he thought he had found a turtle nest, and had already made a big excaration in looking for the eggs. It was pointed out to him that the tracks he saw on the sand were those of an alligator, not a turtle. While the Malay was gazing into the hole in a most disconsolate manner, one of the black boys crept up behind and threw the dead snake round his bare legs. The yell, the hop, and the pace the Malay put on as he made for the boat was vastly entertaining. I doubt if a Malay ever made better time. We had several more turns at the buffalo, and gencrally managed to secure one, but the heat now was so intense, and not wishing to be absent in case any proas turned up, we decided to let the boys do the 
hunting, which they did when fresh meat was necessary.

'Billy,' a big Kanaka boy, Robinson's factotum and cook, was in charge. He was a fine fellow and a good cook, but his ideas of dress were limited in the extreme. The calm way Billy, wearing nothing but a strap and a revolver, used to bring in our food when at the camp, was decidedly funny. I always used a Martini-Henry carbine when after big game. The Snider carbine was generally used, I found; no mistake, it was a bone crusher.

While at Knocker Bay, on several occasions, cattle and buffalo came out on the beach. One of the most charming spots in the whole harbour was not far off from where we were anchored. It is called Turtle Point, so named owing to its similarity to a turtle. There is a gentle rise at the back, where the full benefit of the breeze could be obtained, together with a lovely view of the harbour. A more perfect site for a homestead could not be imagined. I am afraid the day is far distant when it will be utilised. The country round about is open forest, with patches of jungle. There is a charming little bay just beneath, a spot that was all that could be desired in which to keep a boat. Near this little bay was the best place for rock oysters in the harbour, and Port Essington was famous for its bivalves. The oyster, not the shell, was about the size of the yolk of an egg. What wonderful feeds we used to have, to be sure. If required to be eaten fresh, the niggers brought in the oysters whole; if for soup or stews, they would break 
open the shells on the rocks and fill up palm-leaf baskets with the fish. These palm-leaf baskets are beautifully made, and are often used for carrying water. I do not think I ever enjoyed oysters more than on one occasion when I sat up to my waist in water alongside a heap, and with the assistance of a rock and my sheath knife kept on almost like the brook.

Another sort of oyster grows upon the mangroves. Very often they follow the shape of the branch, and are sometimes three to four inches long. They are coarse eating raw, but capital when cooked. Besides oysters, the niggers would often bring in crabs about the size of a pudding plate. A great way to catch them was to put a piece of canvas in the end of a stick and shove it into the holes at the roots of the mangroves. The crabs hung on tenaciously, and were dragged out and captured. The Chinese cook on the Cloud was immense at preparing them. He would cook the crab slightly, then remove all the flesh, which he would chop up with herbs, bread, and condiments, put back in the shell, bake it, and serve up in the shell. Besides the delicacies mentioned, the niggers kept us well stocked with fish, either spearing them in the open water, or poking a spear into the holes of the rocks at dead low-water. Another method of securing fish was by using a jungle plant, evidently a strong narcotic. The plant was bruised and tied to the end of a spear and then pushed into holes where fish were supposed to be. If any were there they soon came to the surface stupefied, but if allowed to, would soon recover. Robinson had also plenty of poultry. 


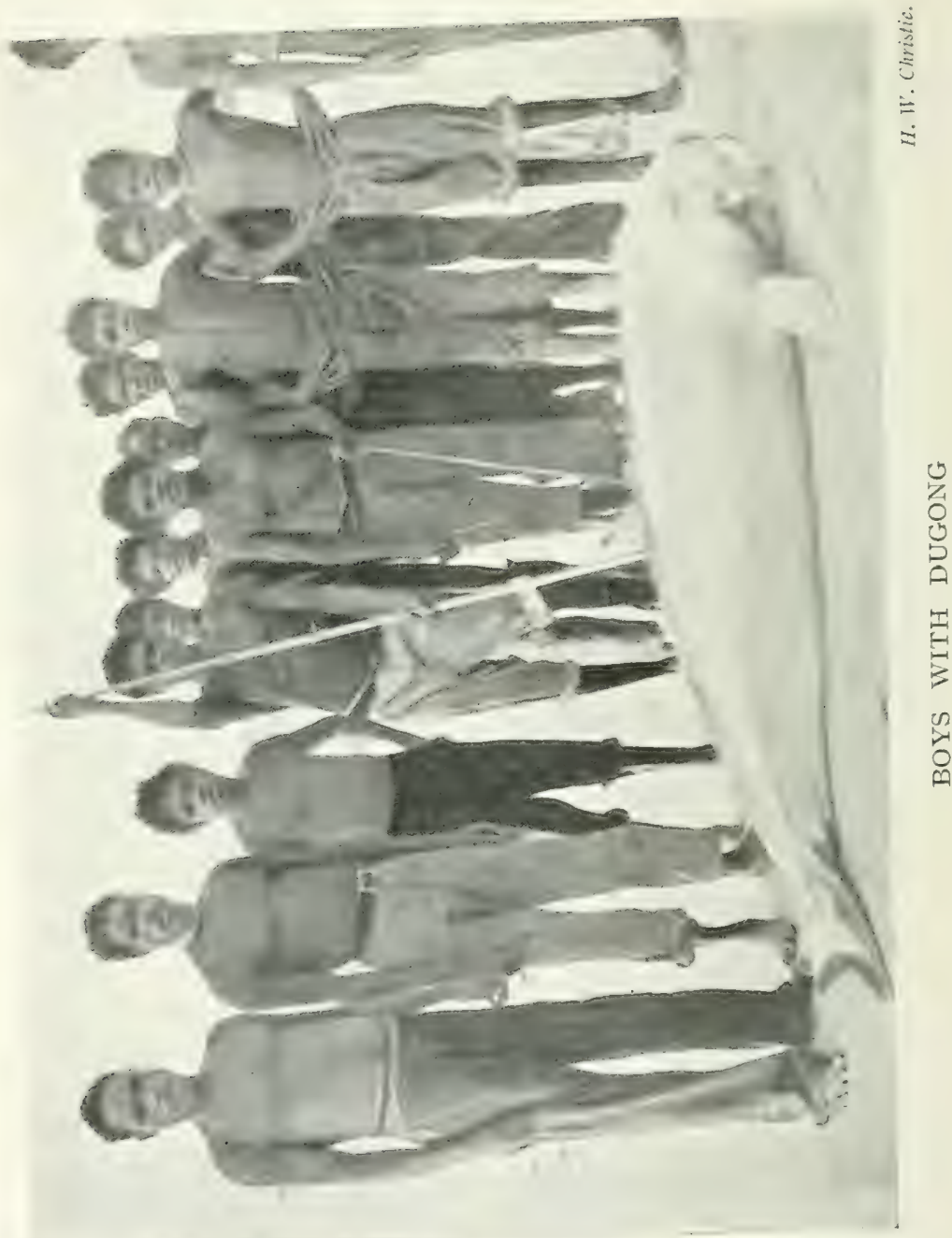




\section{DUGONG}

When it was decided to have a fowl, however, it had to be caught. Then the fun commenced. The bird required was spotted, and all the niggers in the camp as well as dogs would join in the chase. You would sec men, women, and children yelling and racing over a fence, round an outhouse, into the bush, each and every one giving instructions, until out of shecr disgust at such a fool's game, the fowl would sit down and await events. It is apparent we were not badly off for food. Our vegetables consisted of sweet potatoes grown at the camp, and cabbage palm. I am afraid we killed a good many palm-trees in securing the latter. Besides turtle, the niggers occasionally brought in dugong, a large, innocent, weed-eating fish, which they speared. It was a first-rate change both in taste and appearance, being for all the world like pork. We had it fried and roasted, and I firmly believe if I had not known what it was, I should have been satisfied that it was pork. At one time amongst the pcarling fleets on the nor'-west coast dugong was served out as pickled pork.

Alligators were plentiful at Port Essington. Several times I saw them swimming across the bay. They did not seem at all particular what they tackled. Just before our visit a buffalo was drinking in a stream close to the camp, when an alligator nailed it by the head and drowned it. Shortly afterwards, a horse was caught by the shoulders at the same spot. It dragged the alligator about forty yards before the brute let go. Robinson anchored the body of the horse, which was killed, a little distance from a cliff close to the camp. 


\section{IN AUSTRALIAN TRÖPICS}

In due time he had his chance, and the result a fifteenfoot alligator.

To finish on this point, I must mention what I saw at Port Essington. Old Jack Davis, Flash Poll's brother, an aged Port Essington nigger, was preparing a real good meal. A lot of alligators' eggs had been brought in, the contents of which Jack proceeded to extract-in the same manner we have been told that we can't teach our grandmothers-and to deposit in a basin; these, when the basin was full, were fixed up in a manner peculiar to the natives, I suppose. This plan may have been followed to make certain that the eggs were all good.

Christmas Eve, and at last word of the proas. A nigger turned up from Bowen Straits with word that two proas had arrived there and were waiting for me. The masters had sent their papers over, securcly fastened up in a section of bamboo. It turned out as we expected, that the weather had been so tempestuous that they had had to run by. I might here say that I rcalised that Port Essington was a bad place for the proas to report at, for if they once got in with the nor'-wester they could not get out until the south-easter set in. In fact, they only fished in these waters during the south-east monsoon. The revenue station was eventually shifted to Bowen Straits, and formed on the mainland opposite to Oojountambanoonoo, and Port Essington was deserted. We lost no time in getting under way, and were soon beating out of the harbour.

That evening, having occasion to go below while the cutter was just moving through the water, the wind 


\section{CHRISTMAS DAY}

having fallen, I heard what secmed to me the strains of a distant band of music. After a time I located it as coming from the run of the vessel. I presume fish of some sort were following us up, and were making a trumpeting sound, which, combined with the rippling of the water, produced the sweet chords.

Christmas Day found us off Point Smith drifting about, and so we did all day long, the sea like a sheet of glass, the heat of the sun intense, while the glare from the sea made things almost unbearable. I shall always remember my Christmas of 1883 . Likewise the dinner, in which two of Robinson's fowls played a prominent part. During the evening we had a little breeze, which gave us a chance, and we made Bowen Straits. In the morning we sailed further up, and anchored near three proas, another having arrived apparently after word was sent to us. They were the Palare Lambere Djama, Ban Kassie, master; Paduwakang Tjanna Malaya, Balic, master; Paduwakang Bonding Patola, Oesing, master. The masters having come on board, and their papers having been examined, I settled what each man was to pay. Then came the trouble. Each master had only a few sovereigns and a few pounds in Dutch money, and I wanted nearly $£_{50}$ apiece. They swore most positively that was all the money they had, and was all their owners had given them. I felt confident that they were lying, but how was I to prove it. I was properly on the horns of a dilemma. Not being able to pay cash, it was determined to take the balance out in rice, tobacco, and spirits, at any valuation I might 
mention. The Malays proved to be cute customers in the matter of cash. They argued that ten guilders were cqual to twenty shillings. Therefore, as they had to pay fourteen guilders for a sovereign in Macassar, cach one they gave me represented twenty-eight guilders. I agreed with them as far as that was concerned, but pointed out the fact that a pound English was an English pound in this country, and the duties were reckoned accordingly, and that there were only twenty shillings in our pounds. In accepting Dutch money and dollars, the precaution was taken to make an allowance for discount. There being a bit of sea on, I informed the Malays that they could send the cargo on board next morning at daybreak, when most probably it would be calm. About sunset, while at tea, the serang rang out that the proas were getting their canoes on board again and hoisting their yards. It soon became evident that their intention was to bolt. So the gig was at once manned, and we pulled to the Padurvakang Tjanna Malaya, where the yard in which the sail was rolled was nearly hoisted, and which could be set in a few seconds when the yard was once mast-headed. We were only just in time, but the master took not the slightest notice, and warned us off in a most contemptuous manner. He had evidently been drinking. Finding him in this humour, the only recourse was to show the cloven foot, so we three Customs officers leaped on board with drawn revolvers. Robinson sprang at the master, caught him by the throat, and placed the muzzle of his shooting-iron alongside his head. I nailed 


\section{EXTRACTING DUES}

a man to the mast, and Pinder did likewise with another. The soothing influence of the revolvers was wonderfully effective. There was not another move to hoist the sail, and the fellows engaged at it standing at the steps of the mast, realised that it was no time to play the giddy ox. They dropped on the deck without being told; in fact, shut up as completely as ever did an easygoing telescope. The master decided to pay up, and put off all other engagements for the present. Needless to say, I finished my business with the proas right away, sea or no sea. The man who caused the trouble came off second best. Having taken Balic's papers from him, I ordered him to come on board the cutter for them, but he was too frightened, and sent the second in command. I did not press Oesing for his full lot of rice, for I found on inspection that the lower tier of his cargo, consisting of bags of rice, was much damaged by sea-water. It must be understood that when taking out the duties and licence fees in goods, I made an allowance for the crew's consumption on the coast and the run home. As in duty bound, I made a full report to the authorities in Adelaide. After consulting the Crown law-officers, I received an intimation that I must remember that killing on the high seas was not murder under the circumstances. The law-officers were evidently under the impression that the proas were outside the legal limit, viz. one nautical league from the shore, which was not the case. How the beggars must have laughed in their sleeves, for they had the sovereigns on board all the time to the full number required. How 
I found out I will relate anon. The proas sailed that night. I cannot imagine what prompted the Malays to try and get away, unless it was swelled head. Having done us once, they hoped to try it on again. They knew the power of our firearms, however, for when on board the cutter they expressed great curiosity in referto them, which was gratified, and some excellent shooting made. The Malays had numbers of ancient flintlocks on board, but I doubt if they had ever seen any up-to-date weapons before, or they may have fully appreciated the dull sailing qualities of the Flying Cloud, and knew well that, before the wind, it was impossible to catch them once they got a start. So, I think we were well out of it. It must be remembered that our crew were Malays, and our serang had a brother on board one of the proas, a most officious gentleman, who had to be sat upon, and that the proas carried between them over a hundred men.

We stayed on for several days in Bowen Straits, in hopes that more proas would report. During our sojourn advantage was taken to thoroughly shoot over some of the swamps on Cocker Island. We had great sport amongst the geese and ducks. What a difference in the swamps since I was last there at the end of the wet season. All the grass and reeds were burnt, and there were only some small patches of water. The swamps were perfectly flat, and many miles in extent. The day will come when these swamps will be of great value for the growth of tropical products, for they could easily be drained and reclaimed. No game was wasted, 



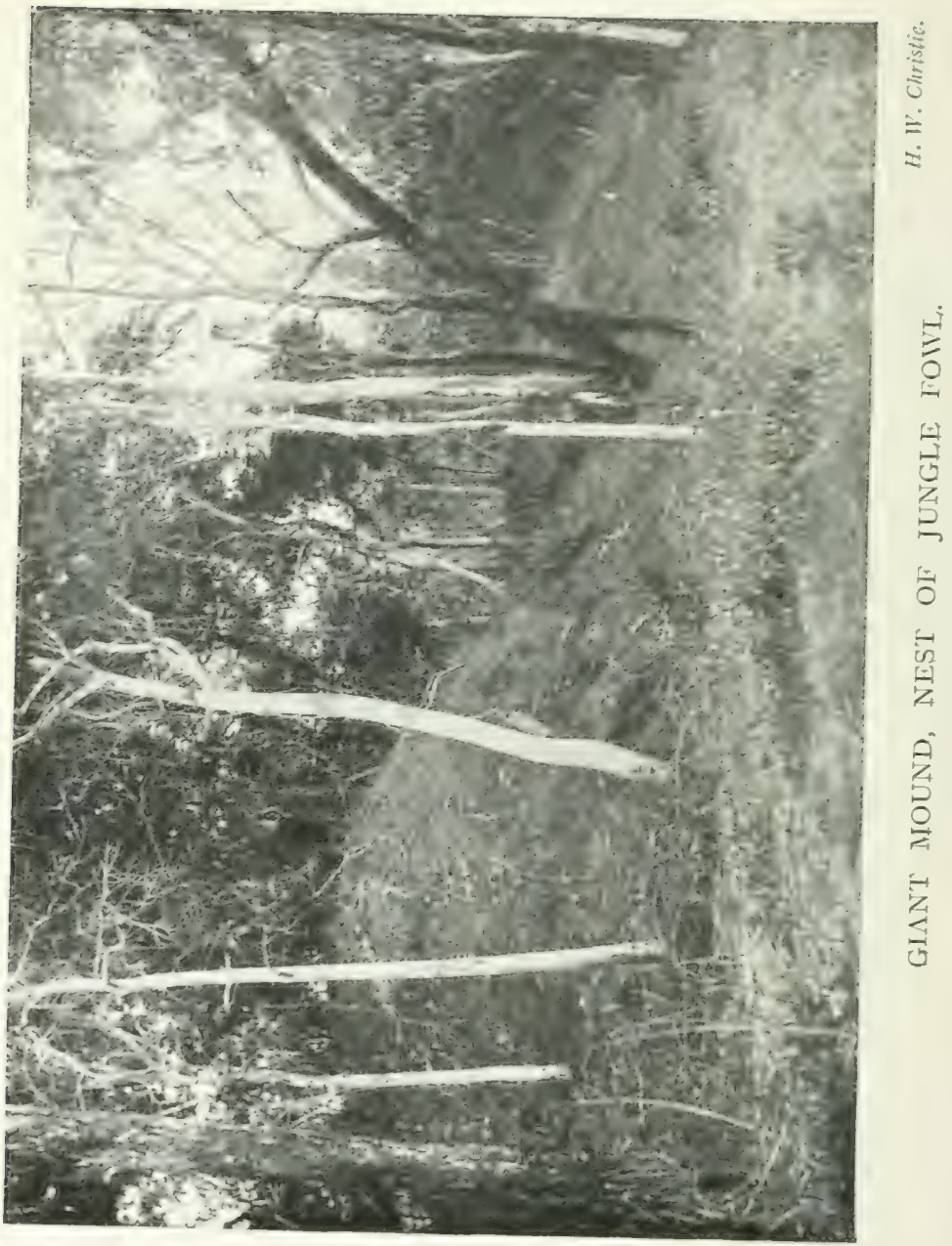




\section{JUNGLE FOWL}

for there were numbers of niggers camped on the islancl who were ready to relieve us of the birds. When we took geese on board, the breast only was cooked for eating. It was splendid when grilled. The rest of the bird was chopped up and boiled down for soup.

We also baggred some jungle fowl, a good table bird. The nest of this bird is a marvel, resembling a small hill. It is generally built in loose sandy soil, the birds heaping up the mound by the aid of their powerful wings and feet. The eggs, to the number of ten to fifteen, are deposited in the cavity, in which leaves and twigs have been placed. The opening is then carefully closed and the eggs left to hatch by natural heat. In due time the little birds emerge fully feathered and ready to go on their own. A full-grown bird is perhaps a little larger than the ordinary barn-door fowl. The egg, which is pinkish-brown in colour and delicious eating, approaches the size of a goose egg.

According to Mr. L. C. E. Gee, of the South Australian Government Service, an authority on ornithological subjects, there are other varieties of this bird in Australia, the smallest only being found on the north coast, but which, strange to say, makes the largest nest. They have been found from sixty to one hundred and sixty feet in circumference.

After waiting at Bowen Straits for nearly two weeks, no more proas having reported, we ran back to Port Essington to have a few days there before leaving for home. On the evening of the fourth day there, 'Moyout,' a very intelligent black I had left at Oojountambanoonoo 


\section{IN AUSTRALIAN TROPICS}

to look out and let me know if any more proas put in an appearance, for the distance overland was not great, arrived, and reported that no more had been there, but that the Alligator River niggers had, and had robbed him of the tobacco and rice I had given him. They also had gone to the Chinese timber-cutters' camp, robbed the Celestials of some rice, and threatened to do for them. The Alligator River niggers were evidently greatly disappointed that no proas had stopped in the Straits, which meant that they had missed their annual orgy. When Moyout came in, all the blacks crowded to the house to hear the news, as many as possible getting inside and round the table, on which there was a dim light. The scene was a strange one, though by no means pleasant, as the heat and smell were, to say the least of them, tropical. All the niggers, men, women, and children, were clothed simply in moonlight, or rather lamplight, and all jabbered away at the same time. A little of this went a long way, so the meeting was adjourned sine die. There being now no prospect of any more proas reporting, it was decided to get under way at once. So once again Robinson was left with his subjects. All hands pretended to be very sorry we were going. 'Flash Poll' especially was responsible for great lamentations, saying, 'O Rob! git it knife to cut my head, captain going away.' As I have mentioned before, this is a curious method the niggers have of manifesting either grief or joy. liefore our departure, in consequence of the dearth of proas, I distributed considerable quantities of rice amonirst the niggers. 


\section{A ROUGH VOYAGE}

At Turtle Point some nisirers were waiting to put oysters on board. These were intended for Darwin friends, but owing to the length of the trip, we put most of them away ourselves. At the camp we shipped several bags of ripe tamarinds.

When once clear of the Heads, we got the full benefit of the nor'-wester, which had freshened up considerably, and there was a nasty sea. The old Cloud was a firstrate sea-boat for hor size, but it would have been a marvellous vessel that would have kept steady in the circumstances. During our beat down to Cape Don, the wind was in one direction, the sea another, and the tide yet another. It was as pretty a jumble as ever I saw. There is one thing that I could always do at sea, that was feed, and this trip was no exception. I was jammed in a corner of the little cabin, and the cook in another. He had a plate of grub, for he liked to do things in style, in his hand, and from it I helped myself with one hand, having a pannican of tea in the other. None of the others on board were taking any. When we reached the Vernons-Clarence Straits-it was blowing very hard from the nor'-west, dead in our teeth, but as we were in time for a bit of the ebb tide, which was against the wind, we beat, or rather were carried through.

When clear of the Straits, a terrible sea, in which we could not do anything, was running. The skipper thought the cutter might manage to ride it out until the turn of the tide, so dropped a kedge and paid one hundred and forty fathoms of line, but she fairly buried 
herself, so there was nothing for it but to up anchor, and run back before the wind. By this time the floodtide had made. Of course, no sail was necessary, for what with wind and tide, we were going through the water and over the ground at a terrific rate. After a run of some miles, the skipper thought he would have another try and bring her up again. It was not a success. The biggest anchor with the strongest cable was let go. Snap went the cable like a thread, and away we went again. It was a dark, dirty night, so things were not cheerful, until we found ourselves in Van Diemen's Gulf again. The race of the tide through these Straits is truly appalling, especially so in spring. I have known a ten-knot boat hardly hold her own going through against the tide. On one side of the Straits is a reef known as the Henry Ellis Reef, which was buoyed, or supposed to be. It can be understood what trouble that buoy caused the authorities. I do not know how many times it had to be replaced. I was there on one occasion when a new buoy was to be placed in position, the old one having disappeared. Of a necessity dead low-water neaps were chosen for doing the work. To mark the spot a five-gallon drum with a light line and sinker was put over the side. It acted beautifully for a minute or two, then the tide caught the drum and carricd it to the bottom. The big buoy was duly placed in position, and acted fairly well for a time.

A few miles to the north of the Straits there were some rocks, and being pretty near to the track of vessels passing up and down the gulf, it was decided to place a 


\section{THE END OF TIIE FLYING CLOUD}

buoy there. One was sent up from the south at a cost of between two hundred and fifty and three hundred pounds, but a most unsuitable one for a tide-way. It was placed in position, and floated splendidly until the tide caught it, when it canted and disappeared, never to be seen again. I suppose by this time it is a mass of beautiful coral. There is no buoy at Roper Rocks now, at least not top-side. The pearlers are constantly diving round the rocks, but they have never sighted the buoy or cable.

Next day fortune was a bit kinder to us, for we managed to get through the Straits again and had a fair wind home.

Poor old Cloud, she did not do much more work. When steam was introduced, it was considered that her services, as far as the Government was concerned, were at an end. She was sold to some Japanese, who fitted her out as a pearler. Just as the work was nearing completion a storm arose, and the poor old Cloud made her last voyage to the beach, where she quickly broke up. I afterwards found her main beam, on which was carved the legend $27 \frac{82}{100}, 64199$, which being interpreted meant her tonnage and official number. I cut it out as a souvenir, and it now hangs in my den at horne. 


\section{CHAPTER V}

\section{CRUISE IN TIIE S.S. 'FLEETWING}

THE expected happened. Word was received that several proas had passed Bowen Straits and were engaged in fishing on the coast. News also came to hand that the niggers at Bowen Straits, as they threatened, had attacked the Chinese timber cutters and murdered two of them. It will be remembered that Moyout brought us word of the threat of the Alligator River blacks. From the statements made by the surviving Celestials through an interpreter, it appeared that one morning ten of the party went to their work about a mile away from their camp, leaving two sick men in charge. On the return of one of the party he found that the two paticnts had been murdered, the hut ransacked, and the food all gone. He immediately started back to his comrades at top specd. The niggers spotted him, gave chase, and tried to cut him off, yelling all the time. The Chinaman got home first. The ten men then started back in a body, and made such a noise with their fearful yelling and screaming that the niggers were fairly frishtencd away. Then followed several days of awful fear and short commons, until the Flying Cloud arrived 


\section{THE FLEETIVING}

with stores, which were not landed, as the Celestials hic? had enough of it, and tumbled on board as quickly as possible. The interpreter, Soo Hoo Yoke, said the men wound up their statement with 'heartily thanking God for their deliverance.' I imagine that that was entircly' Soo Hoo Yoke. He was a Christian, so he said. He attended chapel, sang, and in fact did all things which he thought necessary to stamp him a convert. He desired to be considered a most pious individual, but we who knew him had our own opinions. When the few duties were first imposed, on Pori Darwin ceasing to be a free port, amongst the items on which ducs were levied was opium, the rate being twenty shillings per pound. When telegraphic word was received that the duties had to be collected, together with particulars, the gentle and guileless interpreter was sent by a leading Government official to inform the Chinese merchants. He did, after he had made several good deals in opium for himself. I don't suppose he would be considered less a Christian for that piece of sharp business practice. It was decided that a party should be organised for the dual purpose of catching the defaulting Malays and to endeavour to capture or punish the murderers. A small steamer, the Flcetwing, 2 I tons, was chartered. I was placed in charge of the party, and received instructions from the acting Government Resident (Mr. G. R. M'Minn) that I was to go as far east as the Goulburn Islands, and be away about ten days. However, I had six weeks' provisions shipped. The Fleetwing was not a cheerful boat by any means, being just a steam-lighter. The cabin consisted 


\section{IN AUSTRALIAN TROPICS}

of a match-board construction aft, and proved a gigantic sieve. There being no galley, some curved galvanised iron was procured and a cover for a stove knocked up. All told, we had seventeen men on board. Amongst them were one of my officers, Mr. H. Pinder, and Police Trooper Stott. We started on March 12, 1884. When a few miles on our way the boiler began leaking. The engineer said he must turn back. I objected, and persuaded him to drive a big nail into the leak. It went in beautifully. We had no more bother with that leak during the voyage. Being aware that things on board were not as nice and inviting as might be, I had laid in a fresh stock of cutlery, plates, mugs, and dishes. Those belonging to the steamer we gave a passage over the side. The old man looked when he saw the clean fit out, but had the sense not to pass any remark. We procured all the coal there was in Port Darwin, which quantity just took the steamer to Port Essington, and left a few hundredweight over in case of emergency. When rounding Vashon Head we nearly came to grief, the coast having been hugged too closely. Somebody happened to look over the side and noticed that the reef was only a few inches from the steamer's bottom. Naturally the course was altered. At Robinson's Camp there was anchored a pearling schooner, named the Sree Pas Sair, owned by Messrs. Streeter (a son of Streeter of Bond Street) and Chippendale. The schooner only carried swimming divers, and these, with the crew, numbered somewhere about cirhty men. They had been prospecting for shell, but without any luck. Streeter, on hearing my mission 


\section{A PREDILECTION FOR GROG}

-proa-hunting-badly wanted me to ship him as one of my men, so that, in case we caught any proas, when Government business was through he could board them and do private business in the way of bartering for pearls. I refused straight out to allow him on board, pointing out how nice it would look for a man from a Government vessel, sent on purpose to punish the Malays, to desire them to scll their pearls. Trading under such circumstances would look like compulsion. A bit of a wordy warfare followed, but I stuck to my guns.

Having no coal, we had to fall back on wood, and a gay old time we had in consequence, as the steamer's consumption of that fuel was some six tons a day. Immediately on our arrival our men and a crowd of niggers were set to work to cut and load up wood. During the royage from Darwin it was noticed that one of my party had too great a predilection for the black square bottle. I arranged with Robinson, who had to join the steamer, that he should be put ashore at Port Essington, and left in charge of the camp. The man with the predilection was annoyed. However, that did not matter. So ashore he went with a bottle of brandy as a medical comfort. Now, in Robinson's store there were twenty-four gallons of Malay arrack belonging to the Customs Department, but the man ashore had no idea that such was the case. When we returned a fortnight afterwards, he complained bitterly of being left with only one bottle of grog. The show was then given away. The man's disgust and rage at having been cheek by jowl with twenty-four gallons of grog, and not knowing it, were perfectly won- 


\section{IN AUSTRALIAN TROPICS}

derful to behold. All the Alligator River blacks having cleared back into their own country, there was no chance of making any arrests, or 'dispersing' them.

To resume: Besides Robinson, three of the Port Essington boys joined the steamer. They had previously been with the proas right down to the bottom of the Gulf of Carpentaria, so had a good knowledge of the Malay camping-places. After a run of twenty-four hours we arrived at the Goulburn Islands, and when passing between the South Goulburn and Sims Islands we were cheered by the sight of a dredging canoe, and shortly afterwards opened out two proas at anchor in a nice and apparently well-sheltered bay. We soon after brought up close to the proas. They were the Paduwakang Lambere Loerie, Oveo Nando, master, and the Paduwakang Lakariolong, Ocnose, master. They stated that they did not call at Port Essington because the weather was too rough, so had to run by. Knowing their customs, I believed thcy passed by intentionally, but, taking into consideration the fact that they had sent word to Robinson, I only inflicted a fine of fro in each case. They had enough gold to pay all their dues. The extra value in way of a fine not having been anticipated, had to be taken out in rice. Thcy scemed pleased at getting off so easily. The season had commenced well, for the Malays had already sccured a large quantity of trepang and tortoise-shell. This was comparatively a new camp, the one they had been in the habit of using having been washed away. According to the niggers, the Malays had sorne peculiar customs. Before com- 


\section{A SURGICAL OPERATION}

mencing at a fresh camp they lowered to the bottom of the sea a ncw plate containing portions of the best food they had on board. When leaving a camping-place some ceremony was gone through for the purpose of making wind, but I could not learn the details. There was a large camp of natives near the smoke-houses, but to our surprise they did not seem the least afraid. I think it must have been the sight of the Kapalapi (Malay name for steamer) that held them. It was a great novelty, few indeed of the niggers ever having seen one. A single black had seen something, and very likely a steamer, for he had been diving at Papua. He had been kidnapped.

Of course we wanted more wood, so I set the men to cut it. And hard work it was standing in a big swamp on the slimy, claw-like roots of the mangroves-the only timber available-and using the axe; to say nothing of the smell and heat. I employed about thirty niggers to carry the timber to the boats, and paid them with tobacco and rice, and Turkey-red for the women for nargers (waist cloths) when they were struck that way.

Noticing that one of the niggers was limping badly, I made inquiries and found he had run a sharp piece of coral into his heel. I judged that a portion of it evidently remained. The blackfellow was soon on the ground and his foot in my possession. I immediately sank a shaft through the thick skin, struck coral, and removed it. I always carried the necessary tools for this sort of work with me.

The Malays had fine stacks of wood alongside the 


\section{IN AUSTRALIAN TROPICS}

smoke-houses, so I was glad for their sakes that I succceded in getting a good lot of timber from the swamp. But for this I should have had to annex some from the stacks.

Green and dry mangrove mixed makes splendid steaming fuel. The red mangrove is generally used on small boats for cooking purposes, for it does not create smoke, and when cut small does not cmit sparks. The next evening we anchored off Haul Round Island, ncar the entrance to the Liverpool River.

We thought we would have a try for turtle. As soon as we landed, I saw one of the black boys flop down full length on the grass, and up he jumped with a bird in his hand. Seeing fluttering wings we all started falling on top of them. We soon had a bag of sixty head. The birds proved to be a small black gull. We did not get any turtle. The noise we made was enough to frighten the eggs out of the nest, let alone the live turtle. The Malay cook said the birds were good tucker, so I had them cooked, and excellent they proved.

The sun was still in bed when we steamed to Entrance Island at the mouth of the river. A most agreeable surprise awaited us, for although no proas were there, we discovered large stacks of timber, which on examination we found only needed cutting in half to suit our furnace. That this timber had been brought from the mainland was evident, and from appearances it looked as if the Malays had made a sudden departure. This was not a favourite camping-place, for the niggers were awfully treacherous. It had also at different times been the scene of great 


\section{ENTRANCE ISLAND}

massacres and bloodshed. Some time previously the niggers had killed the master of a proa. Next year the brother of the deccased went there and pretended to start fishing. He managed to make friends with the natives, a lot of whom he induced to cross from the mainland to the island. He then opened fire upon them with his two-pounders. A few managed to make to the water, but the Malays were in the canoes waiting, and finished them off. If the truth were known, I expect if the niggers subsequently had a chance at any other proa, they gave the Malays a lively time. With Malays and niggers it was the same. They did not discriminate; it was simply a life for a life. While we were at the island several fires sprang up on the mainland-signals, I expect. It is said that necessity knows no law, so I, to use a latter-day term, 'commandeered' the timber. If the fellow to whom it belonged ever returned, it must have been a bitter disappointment to him, and his language was no doubt tropical. The little bay in which we were anchored carried four fathoms of water to within two boat's-length of the beach. On the beach we sank two shallow wells, and found beautiful fresh water. Naturally, we had a good look round the island. There were some charming patches of jungle, where everything seemed to grow most luxuriantly. Now and then we would come across a little glade, cool and bright, it being still early, with the dew sparkling on the grass and trees. The birds seemed very tame.

In some of the old native camps there were shells which, if found in the neighbourhood, indicated the pre- 


\section{IN AUSTRALIAN TROPICS}

sence of pearl-shell. It struck me that if ever the Liverpool River were settled, and shipping frequent, the island would be of great importance, as there was splendid anchorage under it-an ideal spot for a depot for trepangers and pearlers. There was good soil for garden purposes, grass for goats, and the jungle for pigs. Of course the niggers would give trouble, but settlement by determined men has a soothing effect. At daybreak next day we made a start for the next camping-place in Cadell Straits, between Elcho Island and the mainland. We went inside the Crocodile Islands through the unsurveyed waters of Castlereagh Bay, and found we had to keep near the mainland, as shoal water extended for miles from the islands. I had a Malay tow-line, consisting of about forty fathoms of stout cotton-line, tanned, of course; eighteen fathoms of brass wire, with a homcmade brass hook, the bait being feathers, ingeniously fastened to small sections of bamboo, which allowed the bait to be pushed up the wire and away from the hook if necessary. I hooked a fine fish, which after some trouble was hauled alongside. In my anxiety to get it on board safely, I ran my hand against the teeth of the fish, and gashed two of the fingers to the bone. Fortunately for me my flesh never festered, so the wound did not trouble me; it was well in a week. I have had fish hooks and fish bones through my hand, and no ill effects have followed. This particular fish weighed twenty pounds and was something like a barracouta. Just at dusk we anchored at the mouth of the Straits. Some tremendous sharks came alongside, and, the water being 


\section{ELCHO ISLAND}

full of phosphorus, they gave a fine display. Early in the morning we steamed into the Straits and anchored.

There were a great number of niggers on the island, but there were no women among them, which was a bad sign. After considerable trouble, the boys we had brought from Port Essington managed to get the better of their suspicions, persuaded some to come on board, and gave them rice and tobacco. I at once engaged a number to help in the timber getting. Fortunately, two of our party were expert axemen; in fact, one had been a cedar cutter in Queensland, so the trees soon commenced to fall. I worked with the carriers. Here is an idea of what fools men are. I had given instructions to the men in the bush that on no account were they to lay aside their firearms. After having been absent for a short time I returned and found that they had slung their revolvers and carbines on a small tree, and were working at about fifty yards from them. I can tell you they heard of it. The niggers have a playful habit of dragging their spears through the grass with their toes, and all the while looking as innocent as it is possible for them to look. If the niggers had only thought of it, they might have given the cutters a warm time. Close to where we shipped the timber was a fine stream of water pouring out of a hole in a large rock. The natives gave me to understand that it was always there.

Just as we were taking off the last load of wood a large alligator came within a few yards of the boat; however, not wishing to frighten the niggers, I would not allow a shot to be fired. I dare say I might just as well, for whell 


\section{IN AUSTRALIAN TROPICS}

we first came together the blacks displayed great curiosity, thoroughly inspecting us and our clothes. One man evidently thought I was a good subject, and overhauled me properly. When he came to the revolver, he touched it, threw his arms around, and said, 'Boom! Boom!'- he had evidently been in touch with civilisation.

Several of the niggers stated that they remembered Cadell passing through the Straits, when he discovered them in 1867. As our steamer was the first to pass through since then, it can be understood that the fact created great interest amongst the Myalls.

There was a knowing young buck on board who had done the grand tour - that is, had been to Macassar, and he assured me that he had pearls as large as the top of his thumb, which, he said, he would bring to us. To give us confidence, he agreed we could cut his throat if he did not keep his word. He did not give us the chance, however, of taking him at his word, and of course we did not get the pearls.

Next day we started to work our way through the Straits. It was blowing hard from the south-east, with heavy rain. When we came to the narrow portion of the Straits, we grounded, but after a time backed off and found a little deeper water. We got through, and anchored in 'half three.' We were bound to do this, as the water seemed to shoal in all directions, and the channel could not be picked up. Being aware that the chart had one fathom marked in the narrow portion of the Straits, I had the curiosity to look to see if it were 


\section{OUR 'OLD MAN'}

the spot where we grounded. I found the sounding had been scratched out. It was not the cook who did it. I must mention that our 'old man' was a bit of a character. He evidently thought that the place for everything, as far as he was concerned, was his bunk. If a tooth-, or hair-brush, or revolver, or in fact anything, were missed, the cry was, 'Look in the "old man's" bunk'; and sure enough, there it would be found, mixed up with blankets, oilskins, sea-boots, and other fixings peculiar to a seafaring life. I remember Pinder, seeing him using his hair-brushes, said, with withering sarcasm, 'Say, captain, would you like my tooth-brush?' The 'old man' replied, 'No, thanks, I don't need one, and went on calmly fixing up his scanty locks. Robinson nearly exploded on one occasion, when the 'old man' helped himself to his belt and revolver when going away sounding. One objects to see his firearms, upon which his life may depend, used by everybody. The 'old man,' both in appearance and characteristics, would have made a good subject for a sketch by W. W. Jacobs.

We had a very smart young engineer, one of the most wonderful whistlers I ever heard. Once he got the engines going, he would start and keep time most melodiously to the beating of the machinery until it rang through the steamer. Sometimes the engines were a bit obstinate, and would not start, then the sounds from the engineer could not be called melody. It was quite a relief, in every sense of the word, when the engines decided to go.

All this time the wind had been increasing until it 


\section{IN AUSTRALIAN TROPICS}

blew a furious gale, with terrific rain. Very soon there was not a dry stitch on board. In this pickle we had to put in three days. Then the gale moderated, and the rain ceased. All our clothes and blankets were sopping and mouldy, so a little sun was an advantage, and the seventeen souls on board simply revelled in old Sol. While at anchor numbers of niggers were seen on the mainland, but it was not until the weather moderated that we could induce them to come on board. When they did, they pointed out that the channel used by the Malays, for they always went through the Straits, never outside the island, was close in to the mainland. This being verified by sounding, we made another start, and got through safely. To save time in getting into Arnheim Bay, we risked an unsurveyed passage between Algar Island and the mainland.

When clear of Elcho Island, we suddenly saw ascending at the end of the island what we thought were clouds of smoke. The dense mass turned out to be flying-foxes (evidently the flying-wombat of De Rougemont).

The flying-fox, or fox-bat, is a nocturnal fruit-eating animal. It is also gregarious. During the day the foxes. with wings furled, suspend themselves head downwards from the branches of trees in thousands. They present the appearance of a strange fruit. The mangroves are apparently their favourite camping-ground. When approaching a camping-place you do not need to sce the foxes to realise the fact, for you are struck with a powerful smell, which is not exactly eau de Cologne.

I have never tackled flying-fox myself, but by the 


\section{EXPLETIVES}

niggers it is considered a great delicacy, and only old men are allowed to eat it. I know at times the language at Darwin was three-cornered when it was found that the papyas (pawpaw apple) had been scooped out by the foxes.

I do not expect that the people in Darwin were different from those of other parts of the world in expressing their annoyance, and getting over it quickly, by the use of expressive language. I always think of a nephew of mine, a young pickle of about six years of age. The story is told by a clergyman who witnessed the occurrence. This shaver was amusing himself on the lawn by driving a peg into the ground. One of his fingers got in the way of the hammer, as fingers are liable to do, so he gave himself an awful jar. Did he yell? Oh no! Ile quietly laid the hammer down, looked carefully round to see if any one were watching him, and then being satisfied that such was not the case-he did not notice the clergyman looking through a window-he jumped up, clutched his finger, and ran round in a circle two or three times, saying, 'Oh, damn, damn, damn!' Having got that off his chest he returned to his play. Even to the child, the expletives scemed more satisfactory than making a song about the mishit.

After a long wade through mud, rotten shells, and coral, we visited an old camp in the bay. From its appearance it had not been used for years. The camp would have made a fine picture, being formed under some giant tamarind-trees, evidently of great age, and the old fireplace was overgrown with weeds and creepers. A few fect from the fireplace was the grave of one of the 


\section{IN AUSTRALIAN TROPICS}

masters of a proa, who had been killed by the natives. The remains of a rough fence were still round the grave.

One of my boys, Moyout, who was present at the killing, but denied having had any hand in it, related how the tragedy occurred. A nigger one day teased the master for grog and tobacco; at last, wearied with his importunity, the Malay struck him. The nigger did not appear to have taken offence at the time, but shortly afterwards, on some pretext, he induced the captain to go with him into the bush, and when there a number of niggers set upon and murdered him. The aborigines then went on board the proa and murdered the cook, and helped themselves to stores.

While wandering about some distance from the old camp after pigeons, one of the party discovered some mangroves recently cut, so it was evident that proas were in the vicinity. Next morning we visited a little sandy island with patches of dense growth on it, which we noticed the previous day, and there, sure enough, we came on one of the snuggest spots that could be imagined for a camp, and it had only been deserted a few days.

Many of the trees had wax-like flowers, with a perfume similar to orange blossom. We then steamed to the western side of Arnheim Bay, and into a magnificent harbour. This portion of the coast had not been surveyed, but we went in several miles, carrying good water. The country was hilly, and there were some fine headlands. This bay is well sheltered, there being several islands at the entrance. The Malays had a campingplace here, Bier, but it was deserted. We then shaped a 
course for Mallison's Island, a boy being stationed at the mast-head. I had promised a pound of tobacco to the one who first sighted a proa. Soon we heard one of the boys sing out, 'I see canoe,' quickly followed by, 'I see one fellow proa.' We steamed in, and there, sure cnough, was my friend Bapa Paloe, the man who drank my square face. He was anchored in a nice little cove, the smoke-houses being out of sight. When the Malays have formed a camp, the mast of the proa is always lowered, and therefore it is very difficult to pick out the hull from the land. It was well that we kept a sharp lookout. The proa was called the Erang Polen. The master, Bapa Paloe, had no excuse to make for being on the coast without a licence, and offered $£_{4}$ in Dutch money in payment of dues, that being, he said, all the Chinese owner gave him. The fact of his being so far to the eastward was evidence that he intended to do us if he could, as he never fished further than Bowen Straits.

The question of taking the proa back with us to Port Darwin, a distance of nearly three hundred miles, was seriously entertained. It was, however, considered too risky, considering the small power our steamer had. Besides, there was the crew to be thought of. Some thirty treacherous, objecting Malays to look after would have been too much of a task. So, instead of confiscating the proa, it was decided to fine Bapa Paloe heavily. I punished him to the tune of $£_{50}$, in addition to the dues. He had not got money enough, but as he apparently had had a good time with trepang and 
tortoise-shell, I helped myself to those commodities until I considered I had full value, and that was not until all he had was on board the steamer. It must have been a great blow to the crew, for they worked on shares. No risk was taken, as a strong armed guard was on board until he was finished with. When the other Malay skippers heard how Bapa Paloe had been treated they were delighted, for he had a bad name amongst them; besides, they had an idea that he was the primary cause of duties being levied.

I secured some very fine pearl-shell from the Malays at this camp.

When wandering over the rocks there, we struck a pretty little scene near the smoke-houses. There was a basin, of perhaps twenty yards in diameter, full of water, left by the receding tide. It was about two or three fathoms deep, and the water was as clear as crystal. The bottom was a perfect transformation scene, containing beautiful coral and seaweeds of various colours, while fish of many hues were swimming about. It was a dream of beauty and peacefulness.

Having supplied Bapa Paloe with the necessary fixings to stop some leaks, for the proa had been on a reef, we proceeded on our way.

The next place at which we sccured timber was Cotton Island, one of the English Company's islands. We landed on a beach close to a dense growth of Casuarinatrees. Work was soon started on these, when down came showers of green ants. Now, when a green ant attacks you, you know it, because it hangs on most 


\section{GREEN ANTS}

tenaciously. These insects have one good feature, however; they are not venomous. You find these delights of the bush everywhere in the Territory. They build their nests in the trees by fixing leaves together, gencrally at a convenient height to knock against. If you do come in contact with them, it is just as well to make yourself scarce. This particular place made me think of a book I had read many years before called The Coral Island. There scemed to be something familiar about the surroundings. The remains of a proa, and the masts and sails of a very large dredging canoe, were lying close at hand. The tide here was tremendous, and it made the boating of the timber very difficult. We started the boat about half a mile above where the steamer was anchored, and it was gradually swept down. It was a case of standing by when nearing the steamer. The boat on one occasion missed the vessel, and a nice picnic it was getting her back. While at anchor the steamer had about eighteen inches of foam up the stem. A little further to the eastward was Malay Road, where Flinders first discovered the proas, and where we had intended to bring up, but in the dark we anchored on top of a coral reef in the full strength of the tide. While here we had a great catch of immense red schnapper. The sharks came, however, and spoilt the fun, and our lines too.

Having taken in our wood, we steamed to Melville Bay, Gulf of Carpentaria. It was interesting running through the islands, all of them being very bold and hilly, and with most peculiar-looking cliffs. All went well until we rounded Cape Wilberforce, when we got 


\section{IN AUSTRALIAN TROPPICS}

the full benefit of the south-easter, for it had come on to blow again, and there was a heavy sea. So we had the full stretch of the open gulf to face. After a nasty dusting we made the bay and found two proas, one of which was without a licence, the Pallidgawaya, Daeng Matoona, master. His excuse I considered fairly good, so fined him only $£ \mathrm{IO}$, which sum, with the dues, he paid up in gold. The extra sovereigns he borrowed from the master of the other proa, Oesing, one of the men who in January swore he had no more money on board. Oesing asked me to sell some rice, as he was afraid of being short. I did, and he paid for it in gold too. I don't suppose before or since he ever bought such dear rice. When we met Rimba at the Goulburns, he informed us that Oesing, who was his partner, had the full amount of money necessary, and was most indignant at his behaviour.

The country round about was hilly, and two of our party (old digsers) said it looked like gold country. They had the same opinion of Bier, the western side of Arnheim Bay. At the smoke-house we found specimens of quartz and ironstone, in one of which a speck of gold could be distinctly seen. It has always been supposed that this portion of the country was gold-bearing. One or two half-hearted attempts were made to prospect, but nothing came of them. Where the tradition comes from I cannot say, but it said that this portion of the coast was once visited by the Spaniards in search of gold. There was also a stack of manganese, which commodity for some reason the Malays took to Macassar. 
At the watering-place I found a great crowd of niggers, but no women. As soon as I landed, a very fine, tall, well-made nigger, who did not look particularly peaceable, came towards me very quickly with his hands extended, but under one of his arms he had a nastylooking Malay knife. I let him understand that he was to keep his distance. One of our boys came up and said that he, the big native, 'was a big captain, all the same you,' and at the other big captain's request we sort of embraced, but not quite. I invited him and his men on board, and gave them tobacco and pipes. I also presented the big captain, Cadado was his name, and each of his staff with small looking-glasses, which they immediately hung round their necks, gazing into them with the greatest delight. I expect they were each wondering at something they never realised beforewhat an ordinary lot the other fellows were. Cadado wanted to put his arms round my neck, but I was not taking any. The masters of the proas came aboard while Cadado was there, and complained that as soon as the rice was cooked for their men, the black captain and his followers took it. I talked to Cadado, and told him that if he interfered with the Malays, white men would come and growl. I also informed the Malays that in a measure they must defend themselves, but that if they used any unnecessary violence they would be punished. Cadado promised never to steal again. He must have had a relapse, however, for not long afterwards the Malays killed him. The Malays told me that they were not frightened of the natives, but were afraid that 


\section{IN AUSTRALIAN TROPICS}

the whites would punish them if they interfered with the blacks. I did not believe this at the time, but it seemed as if it were a fact. As no further reliable information could be gained of other proas, and being many days overdue at Darwin, it was determined to start for home. We had dirty weather and a heavy sea, and making Algar Island at dusk, had to anchor, which we did in sixteen fathoms. The steamer rolled terribly all night. The waters being unsurveyed, we had to be cautious. We steamed through the Straits safely, stopping, however, to load up with fuel. Just as we were departing the niggers brought their women down, the first we had seen since leaving the Goulbourns. This was a sure sign of friendship. We left the Straits on April Ist, and four days afterwards anchored in Port Essington. The only bloodshed we had was during the run back. We purposed having a sweep as to the day we should arrive home. One of our crew, a Malay, after cutting up the paper for the purpose, thoughtlessly stuck his knife, a long kecn-bladed one, in a crack in the hatch, business end up, and forgot all about it. One of our party, not noticing it, sat down right on top of it. The poor fellow rose suddenly, but never a word. He had a nasty gash in his buttocks. Beyond finding sitting down awkward, the wound did not trouble him.

The men having had a day amongst the buffalo, we, for the last time took in fuel, and started for Darwin, where we arrived safely after an absence of twenty-six days. A party was just getting ready to go out and look for us. 


\section{SPIRITS AND NATIVES}

I did not see a single case of drunkenness during the whole trip, and I think the imposition of the duties had the effect of checking the wholesale abuse of the vile spirits which the Malays had been in the habit of bringing down. But the love of drink is strongly planted in the niggers, and they will obtain it when and how they can. In spite of us, I expect the Malays smuggled a fair quantity, for they were up to all sorts of dodges. Bottles of spirits have been found in sections of bamboo, and cases made fast to light lines have been sunk when the officer boarded the proas. The lines were made fast to the bottom of the rudders. The rudders go out below the bottom of the proas, and as the craft get into shoal water, so the rudders are raised. I have found spirits stowed away inside bags of tobacco. Whatever they did they could not carry the quantity they were accustomed to, so a great check was naturally put on the consumption of the awful stuff. The natives were a fine, stalwart, healthy-looking lot, and beyond the signs of a visitation of smallpox, I did not notice any disease amongst them.

The sudden falling off of the number of proas visiting the coast must have been a great blow to the niggers, and, there is little doubt, caused them to look upon the whites as greater enemies than ever, especially since the few proas frequenting the coast had such a limited stock of spirits. It was a well-known fact, however, that previously, at any rate, whites from the sea were better received than those coming from inland. 


\section{CHAPTER VI}

VOYAGE OF THE S.S. 'PALMERSTON'

IN 1884 the South Australian Government purchased a steamer named the Palmerston, of 463 tons burthen, the idea being to utilise her in the waters of the Northern Territory, for Government work generally, such as surveying the coast, rivers, and streams, about which little or nothing was known, and also to land surveying or exploring parties at some desired spot on the coast, which from the land could only be reached by great labour and hardship, and often occasioning weeks, if not months, of travel. Her commander, the late Captain Carrington, was a splendid man in every sense of the word, the beauideal of a British mercantile marine skipper. It is only just over a year ago that he passed into the country of silence, the passing being most truly tragic.

On Christmas morning 1903, the s.s. Coogee, when crossing Bass Straits in a fog, collided with the fourmasted Italian ship, the Fortunato Figari. The upper deck of the steamer was almost swept clean, and poor old Carrington, who was on the bridgc, was lilled instantly, his body being terribly mangled.

On the way from Adclaide the Palmerston called at 


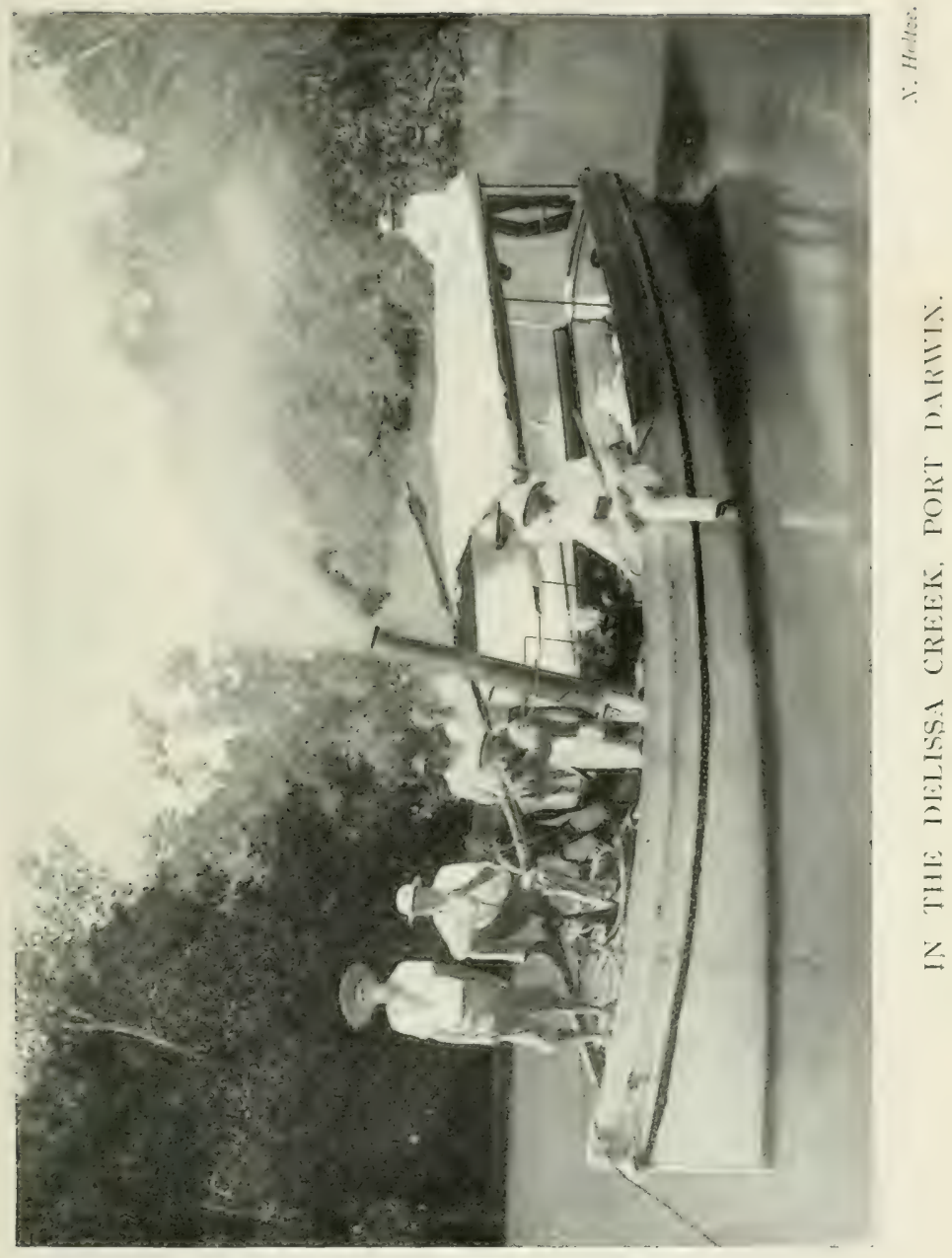





\section{A NEW CATTLE STATION}

Sydney to load stores for a large cattle station about to be formed on the M'Arthur River, Gulf of Carpentaria. In due time she arrived at the M'Arthur, and the cargo was landed about twelve miles from the mouth of the river, considerable difficulty being experienced in getting the steamer up that distance. Except to persons actually starving, I do not think stores were ever more anxiously looked for than these were by those for whom they were intended. Six weeks previously, the drovers had arrived with their mobs of cattle to form the new station, and after a hard and anxious journey, were utterly destitute of stores. During these six weeks the cattle men had lived on beef. It was fresh beef three times a day-no salt, no tea, no sugar, no flour, nothing but beef. How disgusted these men must have been at the sight of a bullock, either dead or alive. Any one acquainted with station life knows how much easier it is to live for a lengthened period on mutton compared with beef.

IVhen making the river, the steamer overhauled a ketch named the Good Intent, laden with general stores. The master, who was also owner, proposed working his way up one of the rivers to some place where the overlanders crossed, for the purpose of trading with them. It was a plucky venture, and deserved to succeed, for nothing was known in reference to the rivers. But the would-be trader neglected to communicate with those pests the Customs authorities. The nearest officer being stationed at Port Darwin, some nine hundred miles away, the adventurous spirit thought he was safe. How disgusted 


\section{IN AUSTRALIAN TROPICS}

he must have felt when it transpired that the purser of the Palmerston, M. A. H. I. Ferguson, was also a Northern Territory Customs officer. After a great deal of beating about the bush, the owner gave Mr. Ferguson a cheque for $£ 52$, representing the duty on the cargo. The cheque was eventually forwarded to Qucensland for collection, but it was returned to me marked 'No account.' How that bird (the dishonoured cheque) came home to roost will be realised by reading the account of this voyage to the end.

In IS85 the Palmerston had to proceed to the Roper River with stores and a survey party, and thence on to the $\mathrm{N}^{\prime}$ 'Arthur River. I took advantage of the opportunity of joining her for the purpose of inspecting as many Malay camps as possible, and to sec what was doing in the rivers from a Customs point of view. Mr. J. P. Hingston, the Government surveyor, and Mr. William Hay, the storekeeper at the Roper, were also passengers. Besides the stores, which were for Hay, there were several horses. At the time of starting, the nor'-wester was blowing furiously. When off Cape Don there was such an awful sea running that we had to put back to Cape Keith, Melville Island, for shelter. Several of us landed on this, the then torra incognita, and proceeded inland a few miles. We saw no recent signs of niggers, and, no doubt, if they had been anywhere handy, we should have been made acquainted with the fact, for they had a bad name for being fierce and treacherous. Hardly ever did a party touch the shores of the island without being attacked, and this within forty miles of Port 
Darwin. Buffalo tracks were numerous. The country seen consisted of ironstone ridges, covered with bloodwood and patches of cypress pine, and paper bark swamps. The weather moderating, we proceeded on our way to Oojountambanoonoo, Bowen Straits, where Robinson was then camped. I well remember rounding Cape Crocker. The steamer was taken inside the Britomart Shoal, by way of a short cut, I suppose. I, for one, felt pleascd when once again in open water, for inside the shoal there was an infernal turmoil caused by the sea, tide, and foul bottom.

Robinson was comfortably settled at his new camp, and in consequence of the Malays being now prohibited from fishing to the westward of De Courcy Head, he had a fair chance of doing well at his trepanging. At that time, however, it was not all beer and skittles with him. The summary punishment inflicted on the Malays the previous year seemed to have had a very salutary effect, for thirteen proas had reported. Nearly all brought the full amount of their dues in gold. Having settled with Robinson as a Customs officer, the men from Macassar proceeded to do him as a trepanger. They made all his best niggers drunk, and enticed them away. Robinson's remarks on things in general and Malays in particular were most sanguinary.

While at anchor, my friend 'Flash Poll' came off to the steamer, as a proof of her great affection for meso she gave me to understand, but I think reasons before mentioned had a lot to do with it. As usual, 'Poll' was dressed in sunshine. One of the officers, 


\section{IN AUSTRALIAN TROPICS}

thinking he could improve her personal appearance, presented her with a pair of white trousers and a singlet. The singlet the old girl got into all right, but the trousers she shipped the wrong way round. Being a well-developed woman, the effect can be imagined. 'Poll was delighted with her get-up, and so were we. Our sides ached for days afterwards.

Leaving the Straits, we called in at the Goulburn Islands camp. Three proas were at work, all being duly licensed. From this point we steamed direct to Groote Island in the Gulf of Carpentaria, having a bad time until round Cape Wilberforce. I have spoken of Dylompo, a camping-place on Groote Island, where the Malays were supposed to have procured large quantities of pearls. I was most anxious to discover the spot. However, Groote Island is a big place, and to have made a systematic search would have taken up too much time. We steamed in and out several nooks and corners and landed several times, but no sign of camp could we find. This was not to be wondered at considering the sheltered and out-of-the-way places in which the Malays usually fixed up their smoke-houses. Noticing some fires inland, at the south-east corner of the island, we endeavoured to reach them, but after two miles' struggle we had to give it rest, the jungle and undergrowth being so dense. Pigeons and quail were plentiful.

On some small islands to the southward we thought we had made an important discovery. For all the world it looked as if there were immense deposits of guano. The deposits proved to be nothing but rock much water- 


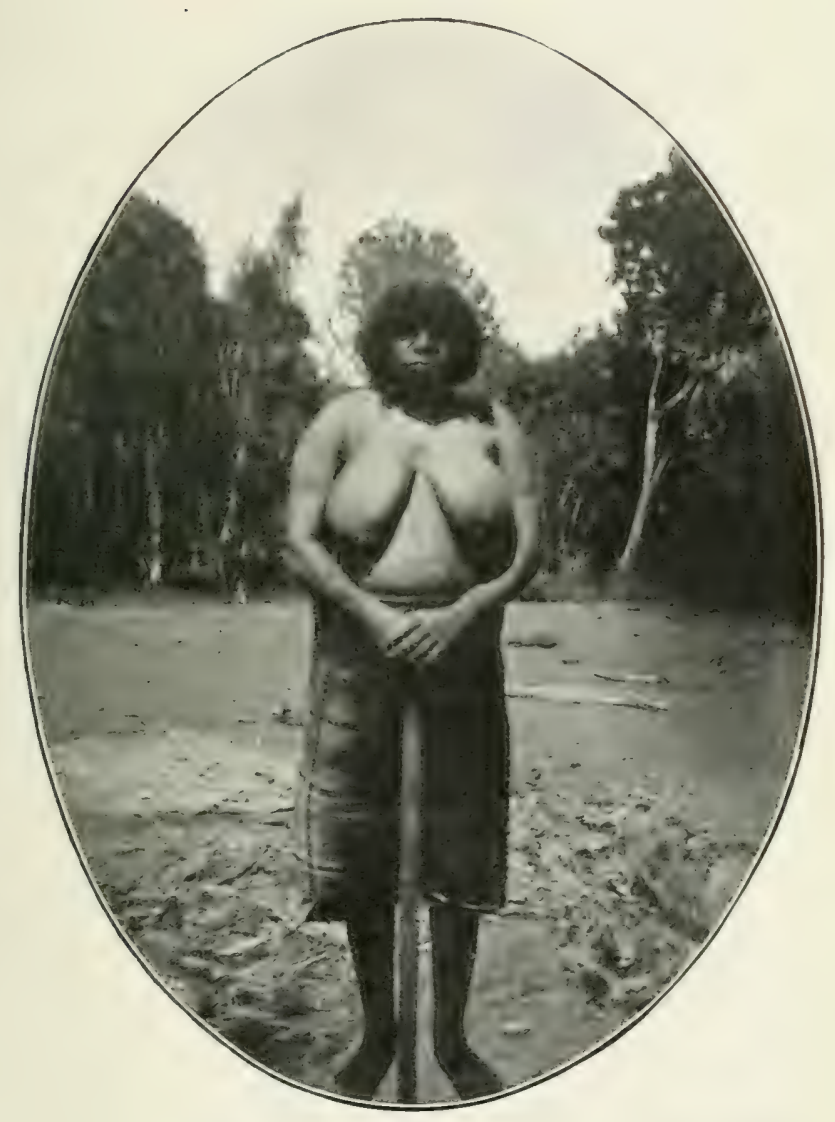

LARRAKEEYAH LUBRA. 

worn, and in such a peculiar manner that they looked as if they had been carved.

Having arrived at the mouth of the Roper, we had to anchor until the channel through the bar could be picked up. Just as the sun was opening his doors, Captain Carrington started in the steam-launch to zigzag where the channel was supposed to be, for it was a shifting one. I went in the launch and soon had a tow-line at work, with the result that I obtained a splendid lot of fish about two feet long. They were something like mullet, and, although new to me, were excellent eating. Having safely crossed the bar, we commenced steaming up the river. By careful navigation the circuitous channel was followed. It was picked up mostly by crossing from high bank to high bank, for where there was bold country deep water could be depended upon. Nearly all the way up, the launch was ahead sounding. All went well until passing a branch river called the Hodgson, when we grounded on a sandbank. The steamer came off during the night and swung round on to the bank, crashing amongst the branches of the trees. It being terribly hot and muggy, with mosquitoes galore, we were all sleeping on the poop, in nets, of course. I did not turn out when I heard the noise, but I think if I had known what I learned in the morning, that the jagged end of a broken branch, about as thick as my arm, was sticking right through my net just above my chest, I should have been out quick and lively. At any rate we got clear of the bank and steamed to a place known as the depot, 


\section{IN AUSTRALIAN TROPICS}

the distance from the mouth being ninety miles. TVe were just over two days getting up to this spot. This magnificent river is navigable for vessels drawing about fourteen feet up to the distance mentioned. Above that shallow vessels could proceed a few miles. The width of the river at the mouth is almost one and a half miles, and it decreases gradually until the depot is reached, where the stream is one hundred and twenty yards across. The country at the mouth consists of low plains belted with mangroves. About thirty miles up, the banks are timbered mostly with gum and acacia, which flourish close to the water. From this point upwards the banks are covered with paper bark, Leichardt pine, gum-trees, many creepers, and beautiful shrubs. There are numerous creeks and rivers falling into the Roper. This river was first sighted by Mr. John Roper, a member of Leichardt's party, on October 17, I845. Two days afterwards the party arrived at the river, and Leichardt named it the Roper, in honour of Mr. John Roper. October 24 the party, after travelling up some miles, reached the bar, which is known now as Leichardt's Bar, where the present settlement is formed. It is only about four miles above the highest point of navigation. This expedition finally left the settled districts in Queensland on September 30, 1845, and reached Port Essington December 17 of the same year. The party returned by sea, reaching Sydney on March 29, I $\$ 46$, when they received a great ovation. Soon after his return to Port Essington, Leichardt started on his second expedition, but after seven months of almost 


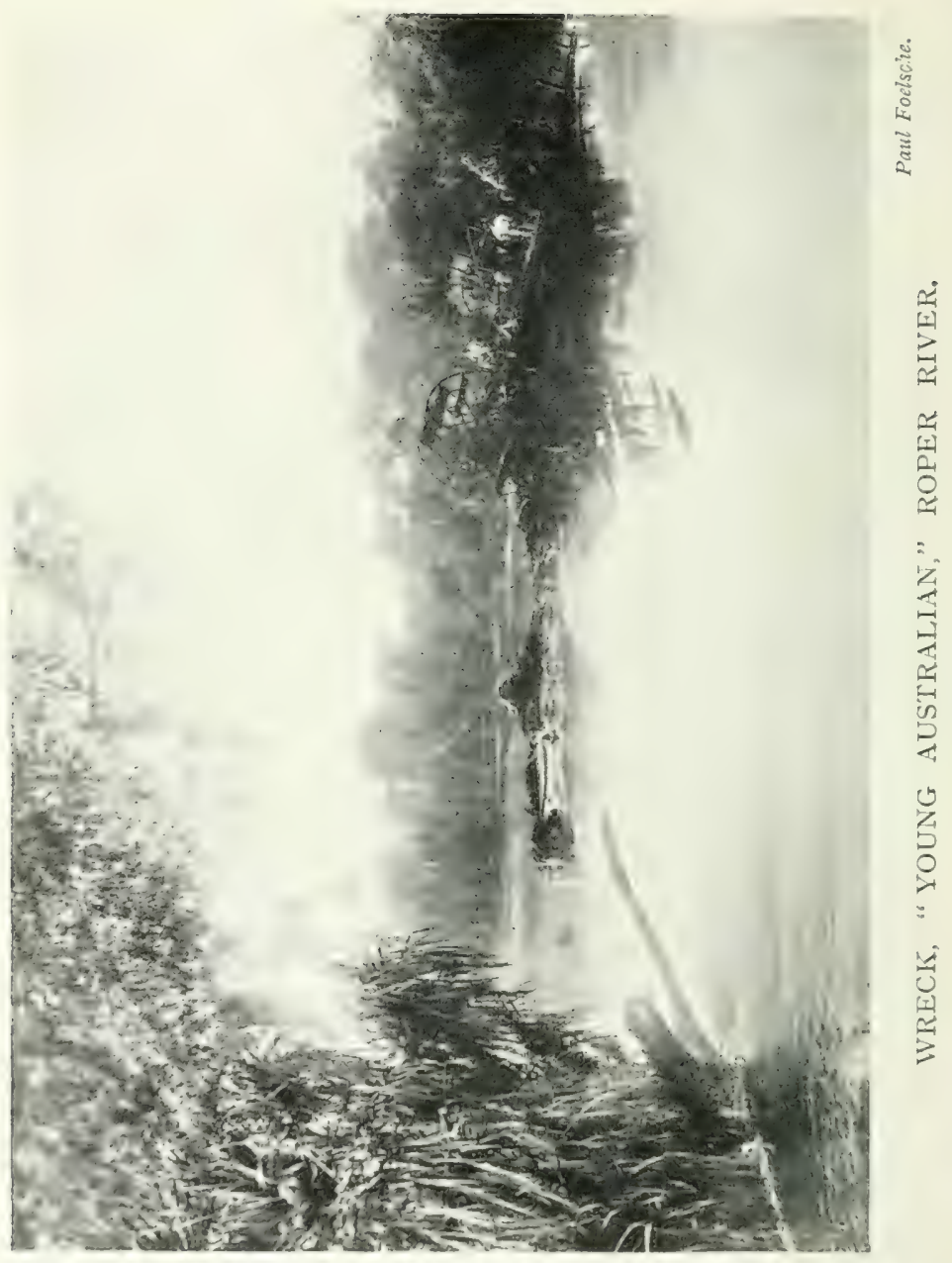


one unmingled course of suffering and privation for them all, was forced to return. On August 9, 1847 , this indomitable explorer started on his third and ill-fated expedition. The last letter from him was dated April 3, I 848 . After that everything connected with this darkly sad episode of Australian exploration is shrouded in impenetrable gloom. Many attempts have been made to solve the mystery, and find traces of the expedition, but up till now in vain.

When steaming up the river, we passed the wreck of the steamer Young Australian, a vessel sent up by the South Australian Government to assist in landing the stores and material for the overland line, when Mr. (now Sir) Charles Todd went to the Roper in I870 or I87I in the Omeo. The Young Australian was engaged in lightering the steamer. I think it was in 1872 that she was wrecked. When I saw her, the ribs and frames of the paddle-wheels were still on the rocks. As we passed, a very large alligator came from the centre of the wreck and disappeared in the water. I passed the wreck many times afterwards, and on every occasion saw an alligator there. I might mention that my comrade in many of the cruises, Mr. H. Pinder, was an officer on board the Young Australian, having sailed in her from Port Adelaide. About I873 Mr. Pinder, having given the sea rest, crossed over from Beltana to the Territory with sheep.

A most useful individual in the bush is the handy-man, for no matter what turns up, he is 'never at sea.' Of course, Mr. Todd and his officers and men had a plentiful 


\section{IN AUSTRALIAN TROPICS}

supply of stores, including medical comforts, which were all landed and stocked at the depot where the party was camped. Now all the cases were marked 'Todd.' One night some wag thought the address could be improved upon, and in the morning, to the great disgust of the chief, the words 'Hot Toddy' were very evident on many of the cases. Strangely enough, Sir Charles Todd, in late years, became the champion punster of Australia.

We anchored alongside the bank, near where the store was built, about four miles from Leichardt's Bar. We went on to the bar in the steam-launch, and there I had a surprise, for I found the ketch Good Intent, and upon boarding her, I learned that she had cleared from Normanton for Darwin with a general cargo, consisting of stores, tobacco, and spirits. In the cabin I found the Customs clearance, which gave a complete list of the cargo shipped at Normanton which was intended for the Roper. The ketch was quite empty when I boarded her. The broad-arrow was quickly placed in one of the masts, and she was seized in the Queen's name. I arrested two of the crew who had stood by her. I might say at once that, wanting men to look after the boat, I gave them the option of standing their trial for being concerned in smuggling or of working on board at a fair wage. They considered discretion the better part of valour, and decided on the latter course. The men subsequently appeared as witnesses in the case against the owner. It transpired that the owner of the ketch, the giver of the dishonoured cheque 


\section{MURDER OF CIAARLEY JOIINSTON}

previously mentioned, and his wife were landed at the $M$ 'Arthur with stores and material to build a store. I seized all the station stores landed at the Roper, but afterwards released them upon payment of fines and duties. There being nobody at the Roper representing the owners of the station stores, I was in a bit of a fix. I could not well let the stores go without duty being paid, and, at the same time, it was a serious matter to take away the stores upon which the outback station people were depending to see them through the coming year. Billy Hay, like the fine fellow he was, paid me the full amount of duties and fines, a good round sum, on behalf of the owners. Naturally, Billy took possession of the stores, which in due time were claimed by the owners and full payment made.

At the 'Bar' there was a store, and, needless to say, at that period it was not licensed. That, however, did not stop the sale of grog. All the cattle from Queensland for the Territory used to come by way of the Roper, so one can understand with whom the trade was done. Not far from the shanty was the grave of Charley Johnston. The tree, under which the grave was, still bore the graphic epitaph-'C. H. J. Murdered by the natives, 26/6/75.' He was stationmaster at Daly Waters at the time of the tragedy, and had, with a party, proceeded to the Bar in quest of horses and bullocks which were supposed to have made back to the depot, the spot where they landed. At the Bar Johnstone met his fate. The day after our arrival a man came in from the $\mathrm{M}^{\prime}$ Arthur to take charge of the 


\section{IN AUSTRALIAN TROPICS}

Good Intent, he having been sent by the owner for that purpose. He came a day too late.

On the Sunday the proprietor of the store invited us all to a picnic at Mount M'Minn, distant about twelve miles. Just as we had saddled up, a party of six men came in to buy stores, and purposed staying just two hours. Who and what the men were we did not inquire. It was not wise to be too inquisitive. Our party was just upon starting when the man in charge of the store said to his boss, "You are a _ fool to go away; there is a century sticking out here.' The thoughtful man then invited the new arrivals to have a glass of rum. Five of them agreed, and the next thing I saw was thirty overproof rum disappearing. The thoughtful man had previously told me that it was thirty overproof, as he had tested it. Upon my asking to see his hydrometer, he cut off a small piece of bacon fat, dropped it into a glass of the rum, and the fat went to the bottom like a stone, the man remarking that that was the way he always tested the strength of spirits. Being satisfied with the simple and to me cleaner instrument, Syke's hydrometer, I did not enter into any arguments as to the why and wherefore, but that the thoughtful man was right as to the strength of the spirits was proved by the sequel.

Speaking of testing spirits reminds me of some experiences I had at Port Darwin in that connection. It was my duty as Inspector of Public-houses to test the liquors sold in licensed houses. One evening $I$ was in one of the hotels with a chum. We were irrigating, 


\section{TESTING SPIRITS}

my poison being square gin. No sooner had I tasted the spirits supplied, than I noted it was not according to Cocker. Now, if there were a spirit I was familiar with it was Geneva, commonly called square face. Almost daily I had to test it; tasting I did without a break. Next morning I sailed into the hotel with my testing instruments. The landlady did not look happy when she dropped to the object of my visit. I went straight for the square bottle. Phew! thirty-five underproof, and it only ought to have been sixteen to eightecn underproof. The sad look on my face consequent on such awful treatment of good liquor was too much for the landlady. She burst out: 'O sir, do forgive me this time! I usually adulterate the liquor, but I let the boy do it this time.' I have often wondered if by accident she spoke the truth, or in her excitement forgot to use the word 'reduce.'

In one of the houses one day I noticed a shelf full of bottled Hennessey's brandy, all capsuled and looking quite nice. Taking one of the bottles down, I noticed the cork was old and discoloured; and I soon discovered that all the others were too. On drawing the attention of the publican to the fact, he remarked, 'Oh yes, we always bottle our own brandy.' Good for the publican, but rough on the customer who wanted and paid for the genuine bottled spirit. The contents of the bottles were brandy right enough, but I have grave doubts as to Jimmy Hennessey ever having had anything to do with it. When a bottle becomes a dead marine, and it has a label, it is an excellent plan to run a knife 
through the label two or three times. It helps to take the wind out of the sails of these unscrupulous brutes, who palm off some vile compound under the name of good stuff. In the cases mentioned, the subsequent proceedings had a very beneficial effect.

The sailor men of our party caused the overlanders considerable amusement by the way they looked after the steering gear, and saw that the saddles had good rolling chocks. The cavalcade, looking as picturesque and comical as Mark Twain's pilgrims in Palestine, at length got away. The picnic, which was held in the midst of fine mountain scenery, in the contemplation of which, and the discussion of solids and liquids, we passed a pleasant day in spite of the fact that twice we had to negotiate 'Hell's Gate,' was a great success. When returning, our packhorse fell and broke its shoulder. Of course the poor animal had to be destroyed. The loss of the horse was rough on Billy, for it was a valuable animal. It came on to rain heavily, but this did not seem to affect the fun at 'the Bar,' which was fast and furious. Shooting at bottles, cards, kip, bumblepeg, and racing were in full swing. I had a race on my nag against a man on foot, and was beaten.

I have heard it said that wherever Englishmen meet there will be found square face, cards, and Lea \& P'crin's sauce. It is true enough as far as my experience goes in the great 'out-beyond ' and at the outposts of civilisation on the rivers. To my idea the most important article is the Worcester sauce. What a godsend it is to all those 
who live out-back! How heartily sick one gets of tinned meat! But the sauce makes it piquant, and, therefore, you can manage day after day to put it away. If you make a stew or a pie, or put a tin on the coals, the sauce still comes in to give the various dishes a distinctive flavour. If it happens to be salt junk upon which you are living, what can be nicer than to drench it with sauce mixed with jam, plum for preference, which makes an excellent chutnee. With every bushman you are certain of finding plum jam. Then again, as a pick-me-up, Worcester sauce, either taken neat or in the shape of a Bombay oyster (raw egg and sauce), is most efficacious. I know, because I have tried the remedy. As a pick-me-up, it is not confined to out-back.

Many of the men in the out-blocks have extraordinary nicknames, generally indicated by some peculiarity. Two chaps at the Roper I remember were called respectively 'the Gutter Snipe' and 'the Queensland Orphan.' One was afterwards killed and burned by the niggers, and the other was well known in the Northern Territory, and was generally 'wanted.'

Many a strange tale could be told of the life and doings on the back blocks, and the extraordinary characters met with at a place like Roper, which was looked upon as a sanctuary for the rest of the States. Many had faces that would take the edge off a razor, smash a mirror, or burst a camera. There were no police within many hundreds of miles, no telegraph nearer than the overland line, and no mail service. I met many peculiar fellows, but I must say that when once they realised that I was 


\section{IN AUSTRALIAN TROPICS}

not a policeman, but merely a Customs officer, I was treated well, and spent many an hour listening to their yarns and experiences. Many I met were on the cross. The man who came with the 'best of intentions,' but did not live up to them, reported that a man had committed suicide at Rosie Creck, about thirty miles from the Limmen River. It appeared that the deceased had been drinking, had fever, and was wanted by the Queensland police. In fact, it was stated that the policeman, a determined fellow, had followed the man across the border, swum the M'Arthur, and was close on his quarry, when a concatenation of circumstances influenced the poor chap to decide 'twere better not be at all.'

In the store there was an almanac with a coloured picture of a hare with the word 'HARE' printed underneath. One day one of the cattle men spotted it. He knew his letters, and evidently had had a speaking acquaintance with a rabbit. Looking attentively at the picture, he spelt out H-A-R-E and repeated the word rabbit. He was satisfied he was correct.

I trust I have not conveyed the idea that all the men we met at the rivers were of the class mentioned. From my personal experience I know nothing against a single one, unless smuggling is considered a crime, which many doubt. But onc can form an idea, and I am certain, with exceptions, the men I met were good, honest, and hard working, although perhaps it might have been as well for a clean skin to fight shy of some of them. Having a spree was regarded as only natural when the chance arose. The boss, poor old Billy, of the store was a proper 
rough diamond, having seen little else but life in the back blocks. He was a thorough horseman and bushman, and kicen to make money (in which he was not peculiar) in his own way, but as generous and goodhearted a fellow as one could wish to meet. That was my experience of him. Poor old chap, he is dead now.

When we were at the Roper landing we required some fresh meat, so arrangements were accordingly made, and a mob of cattle was driven down alongside the steamer. A beast was shot, and I would not like to swear that it was not a clean skin. Some choice morsels were ordered to be put aside for use in the cabin, but the Chinese crew scemed to have a predilection the same way, and the cabin came off second best. Didn't poor old Carrington perform! A number of niggers were camped on the other side of the river. I was informed that they were not allowed across without permission, and, when given this, had to wear a tin plate slung round the neck. It was bad for the health of one crossing without the badge.

IVhen we left a week afterwards, the party, who arrived on the day of our picnic, was still there, apparently not having satisfied their desire for stores. Perchance the century was realised. While a man could satisfactorily answer the simple question, 'Is your breath sweet?' no impediments were put in the way of his purchasing powers. If not, he could go through Hell's Gate. I never saw money of any sort on the rivers, all payments being made by cheque, and some very extraordinary ones would change hands. Many were in a very queer state by the time they reached the bank. 


\section{IN AUSTRALIAN TROPICS}

As can be imagined, I had to accept cheques of a funny character. Some which had passed from hand to hand; some nearly worn out and pasted together; and others which had been wet over and over again and dried. On more than one occasion did the station managers I met on the rivers simply tear out a leaf of a pocket-book and, with an indelible pencil, write out an order on some bank for a considerable sum, and never once did I hear of such an order being refused payment. Amongst all the cheques I received from station proprietors on the rivers or from our revenue station at Camooweal on the Queensland border, with the exception of the one for $£ 52$ previously mentioned, only one for a small amount was dishonoured, and that was due to the station going insolvent.

While we were at the 'Bar,' a man expressed a wish for a Myall nigger boy. Somebody undertook to secure him one. The morning we were leaving, I saw the man who made the promise overhauling his Queensland boys' revolvers. Some time afterwards the party returned, dragging a boy of about fifteen years with them, the nigger yelling and struggling furiously. The man who was anxious for the Myall black refused to take delivery of him. I fancy he got scared at the high-handed business. The look of contempt and disgust on the Quecnsland boys' faces was really very suggestive. We did not hear the remarks of their boss.

One of the men at the store had a lubra, a Qucensland girl named 'Virtue.' This dusky damsel was very nicelooking, and had a really graceful figure. Virtue was a vixen, and her nature was just the opposite to what 


\section{'VirTue'}

her name indicated. This cheerful little lady one day gave her boss a sound hiding because she caught him talking to a white woman. Virtue was a magnificent horsewoman, of course riding man fashion. This fashion was in harmony with the dress, for all the girls belonging to the out-beyond station hands and drovers wear trousers. Now, Virtue made up her mind that it would be better fun to have a trip in the Palmerston than to remain at the store. Just as we were getting under way, she jumped into the river and swam off to us. Two raging men galloped down to the bank abreast the steamer, yelling for a boat. Their request having been granted, the men came on board. They demanded the girl. We had no power to keep her, so she was handed over to them. Twice she jumped from the boat and staried swimming to the steamer. Eventually, the mon succeeded in getting Virtue to the bank of the river. Being determined that the girl should not again give them the slip, her owner and his companion bound her to a tree. The last we saw of Virtue for some time was when we rounded a bend in the river, with the seized ketch Good Intent in tow. When I met Virtue some year or two afterwards, she was again at the 'Bar,' and as happy as could be. Her old boss had crossed the great divide. I am afraid whisky had a lot to do with his shuffling off. Virtue had transferred her affections to another. This man actually became so infatuated with the girl that he wanted, right or wrong, to take her to Darwin, so as to be married to her by a minister. After considerable trouble he was dissuaded from making 


\section{IN AUSTRALIAN TROPICS}

such an infernal ass of himself. How he must have blessed those backblockers afterwards, for he eventually married one of the prettiest and most charming girls I ever met, and became a man of means. While at the 'Bar' we saw a Myall nigger who, if he had never seen a nanto (horse) before, at any rate had never mounted one. Now, this Myall was told to get outside a horse. He commenced operations on the wrong side, and then, to the horse's astonishment and our amusement, he climbed up by fixing his powerful big toes on the protuberance of the foreleg. It was a wrinkle, certainly, but I doubt if many horses could be found that would stand such beastly familiar treatment.

One morning, while at anchor at the 'depot,' I was fishing at the poop, when I hooked a shark abrout three fect long. As I was using a fine line, after some trouble I got it on to the poop. Poor old Carrington was sitting reading barefooted. The shark squirming about got close to the skipper and ficked him with its tail. Carrington gave the brute a kick. The shark resented this and swung round and nailed the poor fellow by the big toc. To use a favourite word of the skipper's, there was an 'irradiance' of a certain description. We were afraid at first that the wound would lead to trouble, but fortunately it healed up. During our stay at the 'Bar,' Mr. Ilingston surveyed a township at that spot. When we reached Gulnare Bluff, towards the mouth of the river, Mr. Hingston had to fix up another township. For what rcason I cannot say. I know he had to do a lot of work in swamps and water. Whiie at work one day Mr. 



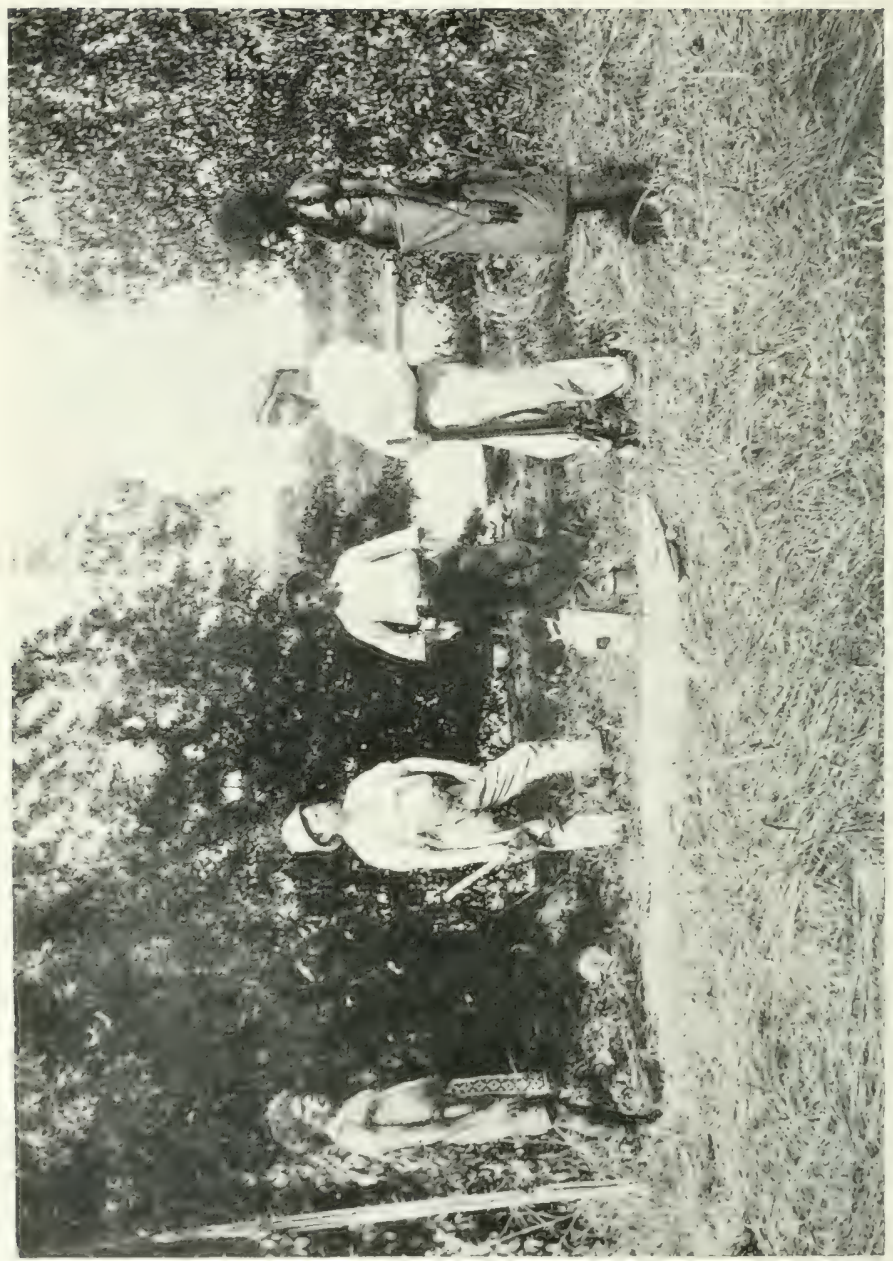

年 
Hingston found an aboriginal dwelling, which revealed evidences of architectural design seldom displayed by Australian arborigines. It was evidently a main camping depot, oval in shape, about sixteen feet long and fourteen feet high. It was built of layers of straw intermixed with good stiff clay. Small openings as windows were numerous all round the sides. The door was the only drawback. This was a mere burrow hole about one foot from the ground, and one was compelled to crawl in on all fours to enter this primitive type of mansion.

At this season of the year, there being plenty of game in the river, we took advantage of the delay to do some shooting. We had real good sport. Alligators were numerous. It always seemed to me that the Roper alligators were the largest on the coast. Some, I am certain, were over twenty feet. In the early days of the Roper, so a story goes, a well-known nautical man saw a big fellow on the bank, and with his sextant took a series of angles which made the alligator thirty-five feet long. Something wrong in the angles, I should think. However, I had reliable information of one twenty-eight feet long having been shot. Speaking about alligators reminds me of our Chinese cook. This Celestial was imbued with the idea that alligators would not touch a Chinaman, so would persist upon bathing in the river while we were at the depot. As he was a good cook, we were somewhat anxious about the man, so Captain Carrington told 'John' that if he caught him over the side again he would put him in irons. Otherwise we would have looked upon it as rather an interesting 


\section{IN AUSTRALIAN TROPICS}

experiment. Amongst the many extraordinary noises which are customary in a tropical river at night, the dulcet tones of the frog from the adjacent swamps were very penetrating. All night, from dark to daylight, it was 'Hot watah, hot watah,' 'Quart pot, quart pot,' 'Deep watah, deep watah, deep watah.' The Darwin frogs I found used the same language. This incessant noise from thousands of frogs was bad enough, but when a single frog camped in the waterspout, or in a hollow tree close where one was trying to get asleep, and kept up a continual croak, the effect was simply maddening. Of course, the frog seemed to enjoy the performance. We always kept a long thin spear handy, so at the first 'hot watah,' 'deep watah,' or 'quart pot,' a rush was made for the weapon, and it was used with appropriate language. This mode of attack generally had the desired effect. It was a common thing in the mornings to see half a dozen great green frogs sitting on the edge of one's washhand basin in the bedroom.

I have tried tinned frog, but never had the chance of eating fresh ones. Judging from the tinned variety, I should say they would be good. If the frogs, great green fellows, we had in Darwin during the wet season were of the edible variety, what a time we might have had. Although we did not eat them, we heard them right enough.

While at anchor in the Roper we experienced several fearful thunderstorms. Of all sights in the tropics, I think the lightning which accompanies a thunderstorm is the grandest and most awe-inspiring. What wonder- 
ful storms we used to experience in Darwin, especially at the break of the monsoon, and how I used to delight in them! Many hours I have spent in a long chair in the verandah watching a storm, the flashes being so vivid at times that you could see trees miles away standing out distinctly against the sky. I well remember one storm in particular, which lasted for many hours, during which time the thunder never ceased for a moment, crashing near you, and then dying away in the distance; then, before the deep growling mutter ceased, crash again, and so it went on. The lightning was simply terrible. Right through the wet season lightning was always about. It was playful at times, and did some damage. We had a very strange instance of its playfulness. In front of the Wesleyan Church there stood a trunk of a dead tree upon which the bell was fixed. It was about fifteen feet high, and nearly two feet in diameter. One evening during a bad storm a fearful flash of lightning seemed to strike the whole town. But it didn't, it just fetched the church. The old tree was sent to smithereens, but the bell was left intact. The lightning having finished with the tree ran along the galvanised fence, burst open the gate, and passed through the door of the parsonage, which it filled with sulphurous fumes.

The sensation caused by finding oneself close to an alligator is certainly not nice. On one occasion our boat was returning from a shooting expedition-we had a large number of birds on board-when it was discovered that two big brutes were close under the stern, 


\section{IN AUSTRALIAN TROPICS}

keeping up with the craft. I was more comfortable on board the steamer than I would have been in the water.

The work at the Bluff having been completed, we steamed out of the river and anchored under Maria Island, which is a few miles from the mouth. This island forms a good breakwater. It is about seven miles long and three miles wide, and the shores abound with excellent fish, not forgetting oysters and cockles. Seeing some blacks on the beach, we went to interview them. They were apparently frightened, however, and abandoned the canoes with which they were at work, and cleared into the bush. Care was taken not to interfere with their possessions, and pipes and tobacco were left where the niggers could find them. Rambling about we came upon an open space of considerable extent marked out in large squares with stones on which were planted, three to five feet high, five or six hollow posts, which were stuffed full of human bones. All the posts were painted red. We, doubtless, had stumbled upon a sacred spot. There were some nice skulls, but not a thing was interfered with.

Leaving Maria Island, we went on to the M'Arthur River, passing through the Pellew group of islands near the mouth. As we rounded one of the islands, we suddenly opened out a very charming picture. Four proas were at work, on the shore were the usual smoke-houses, backed up by high hills covered with deep sreen foliage. Between us and the Malay vessels were a number of dredgring canoes at work, all under sail. The masters of 
the proas promptly came on board and produced their papers. The proas had all been licensed. With one of the masters came my old friend and enemy Bapa Paloe. He said he was pleased to see me. I had my doubts as to that, for since our last meeting he had received Irish promotion, being then only second in command. The Malays called this place Denna Seede. When they heard that white people were settled up the river, they were greatly astonished.

The M'Arthur River was discovered by the ill-fated Dr. Ludwig Leichardt during his great exploring trip to Port Essington in I845. Leichardt named it after William M'Arthur, of Cambden, in acknowledgment of the liberal support that gentleman had given the expedition.

The mouth of the river is situated about nine miles from Centre Island, the channel winding through extensive mud flats, the whole of which are fringed with dense mangroves. A vessel drawing twelve feet can ascend about twelve miles, principally through mangrove swamps. At this point the country improves, and permanent water exists. From here a vessel drawing nine feet may ascend fifteen miles on the top of high-water. Thence for twenty-one miles it is navigable for a vessel drawing six feet. There are fine bold banks, and at intervals deep water, but the numerous reefs and rocks only allow vessels of the draft mentioned to navigate the river. There is excellent anchorage among the islands at the mouth. In the event of any trade arising, West Island would, perhaps, be the best place at which to establish 


\section{IN AUSTRALIAN TROPICS}

a port. Another entrance to the river was subsequently discovered to the westward. I had reason to remember the new entrance, and the story I will relate further on. Amongst the islands are some lovely little bays, whose bright green headlands would be of immense value in other parts of the world as desirable sites for marine residences.

As soon as arrangements were completed we started up the river, the party consisting of Captain Carrington, J. P. Hingston, Arthur H. J. Ferguson, myself, and the men of the surveying party. With the crew included there was a considerable crowd. We towed up a ship's boat laden with our camp fixings and provisions. A few miles up the river we struck a big camp of niggers, but they cleared into the bush as soon as they caught sight of us. We waited some time at the camp, and the blacks returned, satisfied that we did not intend mischief. The usual presents of tobacco and pipes were given, and they were received with the greatest satisfaction. Indeed, we became perfect friends for the time being. To seal the friendship, or perchance it may have been the nigger fashion of 'Looking towards you,' a great buck came to me with a wooden vessel, shaped like a canoe, in his hand, and full of honey. I noticed on the top a ball of grass. The chap held the honey to me, but I shook my head, so he took the ball of grass, whisked it about in the syrup, and popped it into his mouth. After sucking it dry he put it back into the honey, and when nicely soaked, offered it to me again. He evidently wished me to follow his example, 


\section{MR. WILLIAM M'LEOD}

but 1 'passed.' There was a fine iguana in the fire just nicely cooked. This I did try, and it was really gooul, just like chicken.

About twenty-five miles above the mouth we found Mr. William M'Leod camped on the bank. Ile was surrounded by the goods he had taken up to start a store at the MIArthur River. Ile had arrived from Normanton in the Lucy and Adelaide schooner about six weeks previously, and that vessel being unable to proceed further up, had left him here. N'Leod was an old pioneer, both of the Territory and Ducensland. In the latter State he was specially renowned for his experiences with the niggers, and being the discoverer of one of the largest goldfields there, so being marooned did not trouble him much. He had set a couple of men he had with him to cut timber for the purpose of constructing a punt, and had sat down complacently to guard his belongings from encroachments by the blacks. Nor was this a sinecure, as the niggers had made one raid on M'Leod. 'But,' he remarked, 'they didn't stop long. I had just time to fire six shots, and they said "Good-day." There was a deal of suggestiveness in the short speech. That event had happened three weeks before. I said, 'By the way, M'Leod, I am anxious to get a good skull,' but he replied, 'No, you don't; they are all in the river.'

Prior to the sailing of the Lucy and Adelaide from Normanton, arrangements had been made with the Queensland authorities to collect duties for all goods going from the Gulf of Carpentaria and Thursday Island 


\section{IN AUSTRALIAN TROPICS}

to the M'Arthur until an officer was stationed there.

Before leaving Darwin I had received the duties on M'Leod's cargo, about $£ 370$, so one can form some idea of the quantity and nature of it. Subsequently, when the Kimberley rush was on, the Western Australian authorities arranged for me to do the same at Darwin for goods going to Wyndham. I therefore collected the first duties on goods entering that port. After 'looking towards' M'Leod several times, we cleared. We purchased a case of whisky before leaving from M'Leod. Just fancy our surprise when it was broached on the launch to find a lively black snake coiled up in the place where a bottle should have been. The snake soon had a passage. That whisky did not produce any more snakes, for it was excellent spirit. In fact, I do not think there was a snake in a hogshead of it.

Poor old M'Leod, he never left the M'Arthur again. After such a life as he had had, and after such hairbreadth escapes as he had experienced, to die as he did was really pathetic. Soon after he had fixed up his store near the site of the shanty I had pulled down, and trade was promising well, the poor old chap contracted a bad dose of malarial fever. During a fit of delirium, consequent upon it, he wandered down to the river, and on the high bank lay down and died. Thus passed away a man of real grit-the sort of grit shown by the men who have helped to build the Empire. M'Leod was buried where he died. IVhenever I passed the grave, indicated by a fence, going up and down the 


\section{A CONTRABAND STORE}

river, I alway's pictured the old man sitting down quietly amongst his goods on the bank, miles down river.

Just before sunset we arrived at the store the owner of the Good Intent had built on the bank of the river, about twenty miles above M'Leod's camp. When at the Roper I was warned that I might have trouble at the M'Arthur, because the man I wanted was looked upon as a real hard case with a bad reputation; that he would think nothing of putting a bullet through me, and if a crowd of overlanders and backblockers happened to be present, things would be made lively, for it was remarked that they would hardly give up all the liquor without a strong protest. In anticipation of this, I took on all the men of the survey party as glut Customs officers. In fact, the opinion was freely expressed that when my little game was understood, I would stand a splendid chance of getting a bullet. I must own that I felt a little bit like I did when I first visited the theatre. Fully intending, however, to have a say if there were trouble, I had my revolver half drawn as I led the way up the bank. Fortunately, and to my great relief, there was only the owner, his wife, and one other man at the store. It must be understood that at such places the population is entirely floating. I immediately intimated to the owner and his wife that they were my prisoners, and seized the store and contents as contraband, likewise the stores landed for several stations. The latter, upon payment of duties and fines, were afterwards released. In the shanty I found the portion of the Customs clearance relating to the M'Arthur goods, so I knew exactly 


\section{IN AUSTRALIAN TROPICS}

what to look for. Directly I entered the store I was struck with the extreme neatness of everything. It was casy to see a woman's hand had been there. The counter was made of a galvanised iron case, the shelves were empty cases piled up, and all covered with clean newspapers, and the man and his wife were as spic and span as if they had been settled in a city instead of at that extreme post of civilisation. I must own that I could not help feeling sorry for them. I camped on the counter of the store that night, bcing separated from the man and his wife only by a canvas screen. I had my drawn revolver alongside me. In the early hours of the morn the man crept from behind the screen with a lantern, which he held over my face. Although I pretended to be asleep, I watched him. If ever hell were depicted on a man's face it was on his. I suddenly started up with a demand to know what he wanted. He said he was looking for some medicine, and my word he would have got it if he had attempted to play any tricks. The wife was a splendid woman, and as good a bushwoman as one would wish to meet. The following day a very large mob of cattle en route with the usual number of men in attendance arrived. They had bcen for many months on the road, and had looked forward to a real good time at the M'Arthur. So you can form some idea of their supreme disgust at finding a beastly Customs officer in possession. The way some of them came and leant over the counter and gazed reproachfully at me, with never a word, was really touchingr. The men soon hal what they wanted, and 


\section{CATTLE-MEN}

I gave them a helping hand. It seemed that my man had built a large punt out of contraband timber. This M'Leod had desired to purchase very badly, but the owner was not taking any. He did not want any competition, so had put on a prohibitive price-I think it was $£ 500$. IVishing to lend M'Leod a helping hand, as he had paid up like a man, I gave my prisoner the option of selling the punt to M'Leod at a reasonable figure, in which case he could keep the money, or of my taking it to Darwin, which would be the last he would see of it. The man decided to scll, so old M'Leod soon commenced getting his cargo up, Captain Carrington hiring the launch to him, when it was not otherwise cmployed, to tow the punt. Soon everybody was satisficd, except the orisginal owner. One of the cattle men, a man evidently who had been born and bred a gentleman, and who answered to one of the proudest names in England, celebrated the occasion of the arrival of the new stores by purchasing a case of porter and a case of 'square face.' These were opened, and everybody invited to help themselves. Oh, the fellows had a merry time! It seemed as if it were every one's birthday.

Whatever my man was, or had been, one could not help admiring his pluck and grit in pushing his way to unfrequented and almost unknown places. The day after the arrest, to my satisfaction, the prisoners were placed on board the Palmerston, and the Good Intent taken up the river as far as she could go with safety, to receive the seized goods.

When leaving the Palmerston in the launch, with the 


\section{IN AUSTRALIAN TROPICS}

Good Intent in tow, the owner rushed to the stern of the steamer in an awful rage, yelling his protests against my using his boat to bring down his cargo. Seeing I took no notice of him, the curses he hurled at me became more sulphurous. Everything was taken, even to the framework and iron of the store.

The incidents in connection with this seizure were brought back to me some little time ago by a letter I received from Captain Creswell, R.N., the present Director of Naval Forces of the Commonwealth. Captain Creswell said: 'Once there was a naval officer wandering loose on the tablelands exploring and taking observations. He was cheered over many dry stages by his companions' assurances of some splendid lager beer at M'Arthur when we got down there. We got down there, but we never got that lager down. It had been seized in the schooner or pub. That was the first time I ever heard of Searcy.'

At the time Captain Creswell mentions, he was engaged opening up a stock route from the M'Arthur to Powell's Creek on the overland line. This work he successfully carried out.

We camped at the M:Arthur for about ten days, during which time Mr. Hingston surveyed a township, and it was decided to call it Borroloola, which I understand meant fresh or running water. We had an awful time, for the heat was intense. To give you an idea, the surveyor wanted another day to finish his work, and as we were all anxious to get away, he asked me to go with him and give him a hand cutting pegs. It was 


\section{PEGGING OUT A TOWNSHIP}

Sunday. We made an early start, and after some four miles' walk commenced operations. As the day advanced the heat became unbearable-it made one's eycbrows crawl. So after about an hour at the peg-cutting I assured the surveyor that I had grasped all I desired to know about the profession, and was quite competent to occupy any position in connection with it. Then 1 started back to the camp on my own, and I was thankful indeed to reach it. Early in the afternoon the others commenced to come in, but not together by any means. Two of the men were so exhausted that they did not return until evening, having rested under a tree. It being the wet scason, we were worried by innumerable crawling things, particularly at night. The language used by Captain Carrington and the surveyor was very fine, for they had to take sights at night, and chasing stars over an artificial horizon with your eyes, nose, and ears full of insects, to say nothing of others drifting down your back, was not conducive to good temper. By perseverance-I can't say patience-good sights were obtained, and the position of the township fixed. I visited an object of interest a few miles above our camp - the tree marked by the explorer Ernest Favenc, some six years before. While going up and down the river we sighted hundreds of kangaroo, but the bird life at that time of the year was scarce.

I wonder if any of my readers have been kept awake by the Texas cattle bell, the bell usually used by bushmen on their horses. There being a number of men encamped near by, of course that meant numbers of 


\section{IN AUSTRALIAN TROPICS}

horses. All the horses were belled before being turned adrift, so if they wandered they could be easily traced. Some were hobbled as well. As long as the animals kept a little distance from the camp all was well-in fact, then the sound of the deep-toned bell is rather pleasant; but to be suddenly awakened by an infernal jangle of bells, caused by the animal's frantic endeavours to get at some part of its body (which it was impossible to do) where the insect pests had decided to have a little fun, was calculated to cause a flow of language more or less tropical. In Darwin, nearly all the residents who had horses turned them adrift at night. belied, of course. These animals always scemed to make for my quarters, so I was nearly driven mad by the confounded din. I tried my hand at reducing the nuisance. The horses were driven into a yard and all the bells removed and mysteriously lost in the bush. People who at first could not imagine what had become of their bells at last grew suspicious. Chains and padlocks were then used instead of leather straps. I must confess that I rose to the occasion. With a powerful pair of pincers the tongues were wrenched out. The horses appeared to enjoy the fun, but the people did not. It just about killed the nuisance.

There always scemed some sort of pest to keep the horses' minds occupied. There were flics of several varietics, and mosquitoes of many breeds. l'oor brutes, how they used to suffer! I have seen horses and cattle rush like mad things down to the sea, plunge in, and wade out until only the bare tip of the nose was visible above water 


\section{A SCOTCHMAN'S 'POISON'}

If there are any birds for which I have a great admiration they are the Native Companions. At the M'Arthur I saw the largest flock of these birds I ever witnessed. There must have been hundreds of them. I walked after the flock for some miles, but they just kept out of range, dancing minuets and quadrilles, and bowing in a most artistic and graceful manner. I often thini how Gould, the great ornithologist, would have enjoyed that sight.

Several of the out-station people came in, and we gave them a day on board the steamer. There were some rcal backblocker chaps, who donned new moleskins for the occasion, but they did not trouble to take the paper off the buttons. On our way down, of course, it was necessary to stop at M'Leod's camp to get something to clear the bronchial tubes. There was one great Scotchman among the party, who, when I asked him what his poison was, said, 'Weel, I'll just take a tin of fruit.' He had a tin of pineapple. Now the price of preserved fruit at that time, and in such a place, was something to make you sit up, so the Scotchman scored.

We had a little experience, the result of shanty life. A man had been at the Roper having a good time. He desired to get to the $\mathrm{M}^{\prime}$ Arthur, and his cheque not being exhausted, he had to take the balance out in watches. He came into our camp at night, and tripping over a tent-peg, went head over heels into the river. When fished out he was none the worse for his ducking, but the watches were sick. 


\section{IN AUSTRALIAN TROPICS}

When the work upon the M'Arthur was finished, a start was made for Darwin with the ketch in tow. A tow of nearly nine hundred miles in the teeth of the nor'-west monsoon was no joke. I often sat aft and watched the mass of foam astern which was caused by my prize, and speculated on what might happen; but nothing bad occurred. I am satisfied that the two men I had taken from the Roper earned their money, and none was more thankful than they were when we reached our destination.

When passing Groote Island we landed on one of the small islands adjacent to look for turtle. Our quest was of no avail. Perhaps the numerous fresh nigger tracks accounted for that.

When off Melville Bay, just near the island, our steering gear carricd away. It was blowing furiously from the nor'-west at the time, so for a few minutes matters were lively on board. However, the handy-man soon put things to right, and we proceeded on our way.

In passing the English Company's islands we noticed a fine waterfall tumbling down over a cliff into the sea. Of course, that would only last during the wet season. On our way home we passed through Cumberland Straits, and anchored off Point Dale, where we landed. The beach was plentifully strewn with pumice-stone, probably washed there from the Straits of Sunda some twelve months before. On the beach I found a Qucensland bean just sprouting. I took it with me to Darwin in a boullic tin. I left it in my office from Saturday until Monday, rluring which time the shoot errew just eighteen 


\section{A WARNING}

inches. I then planted it at my quarters, and it rapidly spread over the bamboo trellis. Then the white ants had a say, and that was the last of my bean.

On the way home we called in at Bowen Straits to relieve Robinson of the duties he had collected from the proas, some $£ 600$ all in gold. As can be imagined, he was greatly pleased to get rid of the money, being the only white man at the station. For greater safety he had watched his opportunity, and when all the niggers were away had buried the gold in the bush. If his black men had had any idea of the value of money he might have had an unpleasant time.

Soon after our return to Darwin, I prosecuted my prisoners. The man was fined, the charge against the wife being withdrawn. The ketch and cargo were forfeited, and sold by auction.

I have already mentioned the cheque for $£_{52}$ which was dishonoured. Having the giver of it in my hands in Port Darwin, it may be taken for granted that the cheque was duly taken up. $\mathrm{He}$ and his lawyer made a hard fight for it, but the man had to part.

One evening the wife of the man I arrested at the M'Arthur came to my quarters to warn me that her husband had left the hotel where they were staying with the avowed intention of shooting me. She said she had succeeded in persuading him to leave me alone; still she thought it was her duty to warn me. He had been drinking. Nice sensation to have a man around thirsting for your blood.

Just note this and draw your own conclusions. The 


\section{IN AUSTRALIAN TROPICS}

purchaser of one of the seized casks of spirits told me that, being dubious, he opened the cask, and found a number of cakes of tobacco nailed on the inside. The police were eventually stationed at the Roper and M'Arthur, and Mr. R. G. M'Minn (the Government Surveyor and Acting Government Resident) was appointed stipendiary magistrate at the latter place. Mr. M'Minn was succeeded by the landing-waiter from Port Darwin. Mr. Stretton has been over thirty years in the Northern Territory, and is an extremely valuable officer. $\mathrm{He}$ is a great authority on the aborigines, especially those of the Gulf of Carpentaria. In I 893 he communicated an interesting paper to Professor Stirling on the customs, rites, and superstitions of the aboriginal tribes of the Gulf of Carpentaria, with a vocabulary. Mr. Stretton showed conclusively that there is an admixture of Malay blood with the niggers of the north coast. That intercourse with some foreign people existed more than a century ago is proved by the records of Matthew Flinders.

I consider that I had wonderful luck in having such varied experiences in connection with my work. I doubt if ever a Customs officer had such good fortune before, at any rate in Australia, and I can look back on my work and say, 'All's well that ends well.'

The men from Macassar never called their campingplaces on the coast by the English or chart name, but christened them in their own language. I kept a record of these titles. The following are the names of the principal camping-places to the eastward of Port Darwin. 
Our own map name is given first, the Malay substitution for it being printed in brackets :-

Popham Bay (Limbamammo); Blue Mud Bay (Limapeo); Trepang lay West (Limba-bunang tunang); Trepang Bay East (Limbabeenunga); Record Point, Port Essington (Limba Caraja); Port Bremer (Limba Mootara); Raffle Bay (Angaraseetora); Crocker Island, first camp (Batueja); Crocker Island, second camp (Oojouncarorunggo); Crocker Island, calling place, revenue station (Oojountambanoonoo); Copeland Island, Mount Norris Bay (Cara Peepeepee); Malay Bay (Limba Râja); Goulburn Islands (Hungarooda); King River (Marago Chukee); Junction Bay (Limbalachlumbo); Entrance Island, Liverpool River (Lee Monic Monie); Castlereagh Bay (Limba Tordee); Cadell Straits, first camp (Morrunggo); Cadell Straits, second camp (Oojounlamburon); Cadell Straits, third camp (Sallalaboo); Buckingham Bay (Paringa); Arnheim Bay (Limba Katona); Arnheim Bay, west side (Beir); Mallison's Island (Limba Cheepa); Melville Bay, Gulf of Carpentaria (Limba Pandria) ; Melville Bay, Gulf of Carpentaria, outside (Limba Jona); Melville Island, Gulf of Carpentaria (Coolacorra); Sir Roderick's Rocks, inside (Carra Caringa); Caledon Bay (Mungoola); Groote Island, west (Dylompo); Blue Mud Bay (Churapee); Roper (Wakea); Pellew Group (Dinna Seeda). 


\section{CHAPTER VII}

\section{LAST TRIP OF THE S.S. 'ELLENGOWAN' - A HAZARDOUS VOYAGE}

ON June 20 , ISS6, I started on a cruise which certainly for discomfort, excitement, danger, and hard work beat any other trip I had on the north coast. Information had been received that a ketch called the Budgaree, with a large cargo of stores, had left Thursday Island for Borroloola, M'Arthur River, without having first cleared at the Custom-house. In fact, the master had defied the authorities. So I took advantage of the first trip of the rehabilitated steamer Ellengowan, which was under contract to carry mails to our gulf ports, to try and catch the ketch and bring the master to justice. The clearing out of the ketch from Thursday Island, in conjunction with the fact that the man I had arrested at the M'Arthur River the previous year had reopened his store, made things look a bit suspicious. I had with me Mr. II Pinder, in case there was any navigating to do, as he held a mate's certificate. Among the passengers was the late Corporal Power, officer in charge of the native police at the Roper.

The lillengozvan, a steamer of some 30 tons net register, 


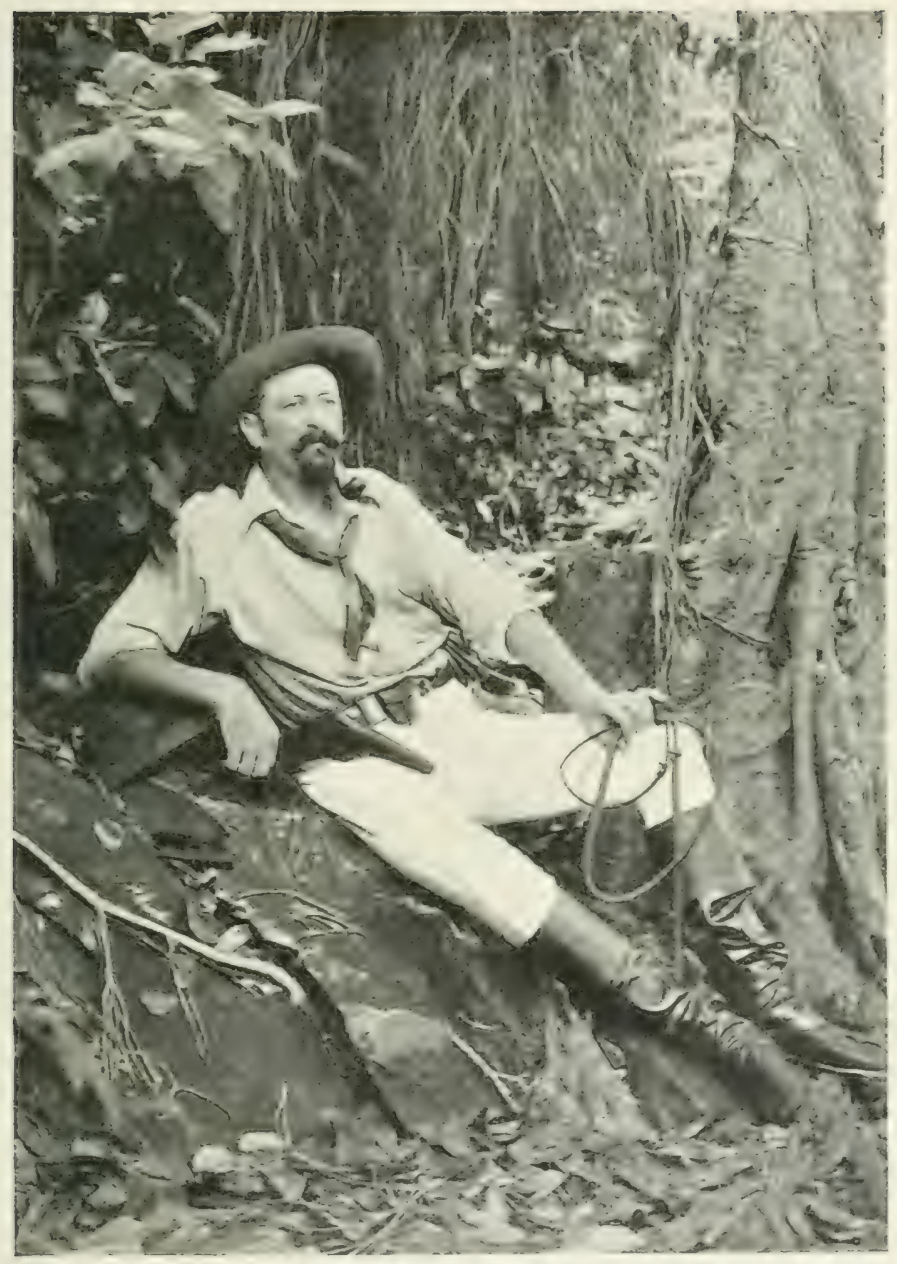

T. H. Harwcor.

THE AUTHOR IN BUSH COSTUME. 

was built in Christiania about 1966 . For some time she was cmployed on the New Guinca coast in connection with the mission work. Somewhere about ISSO, the vessel was bought by the Sugar Company on the Daly River, but almost immediately afterwards she was wrecked in the river, where she remained for about four years. The steamer was eventually raised, and purchased by Mr. C. S. Copeland, who had her overhauled, and he and others thought she was thoroughly repaired.

If my readers will take the trouble to follow the experiences of the steamer during her forty days' absence from Port Darwin, they will realise that it was hardly possible for a vessel to be in a greater howling mess than the s.s. Ellengowan was. The worst feature of the case was the fact that most of the trouble might have been prevented if honest labour had been put into the work of repairs. There can be no doubt the engineer who passed the machinery, and the master mariner who examined and passed the hull, did their work, to say the least of it, in a most perfunctory manner. I had a sort of presentiment that the voyage was not going to pan out well, so I did what I never did before or since prior to starting on a cruise, I arranged all my private affairs as far as possible in case anything untoward happened.

Upon the strength of the reports by the 'experts,' Mr. Copeland accepted the contract to carry mails to the gulf ports. One strange thing about the machinery, when the steamer was raised and the mud cleaned out 
of her, was that it was almost as bright as the day the vessel went down. There was something good in Daly River mud apparently. The preliminaries prior to starting were not encouraging. The first engineer engaged filled the boilers chock-a-block with water, then lit the fires. The fact was discovered in time, and the engineer got a passage ashore. After great difficulty the owner succeeded in engaging two men as first and second engineers, and two splendid fellows they proved. But for their untiring energy and watchfulness, and the seamanship of the master (Captain Macredie), none would have been left to tell the tale. The engineers' names were Ben Griffy and Shaw. Griffy, the chief, was nearly stone deaf, he having lost his hearing while in the Arctic regions. I think he served under Captain Nares. Just before we started it was found that somebody had forgotten to withdraw a plug of wood from a valve hole, or whatever it is called, in the bottom of the steamer. A man dived underneath and fixed that properly. When we finally started soon after daybreak, there was a light south-east breeze, so it did not come home to us that we were like a half-tide rock on account of the boat being so deeply laden. As hour after hour passed away, and we merrily logsed off our seven knots an hour, we congratulated ourselves on the satisfactory state of affairs. We cxpected to have a quick trip; but alas! the 'best laid schemes of mice and men gang aft agley,' and so it was with us. We passed the Vernons all right, but when we reached the open water on the other side we found the wind had 
increased to a regular gale, and raised a short choppy head sea. By the actions of the chief we noticed that everything was not running as smoothly as we could wish. However, nothing very alarming occurred until five in the afternoon, when we were well on our way to Cape Don. Then the engines stopped short, not to go again until repairs had been effected. We were lying exposed to the full strength of the south-east gale and the heavy sea raised from the full depth of Van Diemen's Gulf, with the coast of Melville Island under our lee.

All night long we were at the mercy of a raging, relentless sea. We were gradually set into the coast of Melville Island, and if we had struck there it would soon have been all up with the steamer. It was not an inviting prospect, for if we were cast away, the chances were small of any one reaching the shore through such a surf, and then again the outlook of any one succeeding in getting ashore was not cheerful, for as I have already stated, the niggers on the island were fierce and treacherous.

The engineers were at work all through the night. Some of us passengers assisted by holding them up while they were at work, for the rolling and tumbling of the sieamer was terrible in the extreme. The machinery having been screwed up, packed, washers inserted in many places, and some portions lashed together with wire and rope, it was at last supposed to be in a fit state for another try. I am not exaggerating.

The great thing that troubled me during the night 


\section{IN AUSTRALIAN TROPICS}

was hunger, so at daybreak, when released from my position as a support, I crawled to the locker where some tucker was kept, and with my sheath-knife yanked off a great chunk of ham and of bread, and having jammed myself in between two skylights proceeded to consume the provender. The skipper, catching sight of me, exclaimed, 'You are well all right.'

One great roll the steamer made threw a tin of castor-oil into the chief's face, a quantity of the beastly stuff going down his throat. He had a bad time for a bit.

Soon after daybrcak the engines were going once again. Until 3 A.M. next morning we hammered away trying to get round Cape Don, during which time it was necessary to tighten up things in the engine-room several times.

Finding that we were losing more by leeway than we made, the boat's head was put in the direction of Cape Otham, the nearest shelter. This was reached about 8 P.M. on June $2 \mathrm{I}$. The engineers made a thorough overhaul of the engines, etc., and we found among other defects that the machinery had not been properly fitted and keyed. The whole of the bearings had too much play. Some of the bearings of the shaft had never been bolted down, nor had the donkey-engine been fastened to its bed. The forepeak we found to be nearly full of water, which came through an opening in the plates. These we tommed down, and made water-tight. There were several rivets missing.

In the face of all this we might reasonably have 


\section{A CREW OF JONAHS}

returned to Darwin, but we decided otherwise; and, as repairs had becn effected, a fresh start was made. From this time until we reached the Rinper, fourteen days afterwards, it was one incessant tinkering and repairing of some minor defect in the machinery, while at least cvery twelve hours we had an absolute stoppage owing to the griving out or breaking down of some more important part of the engine. For the first two or three days we accepted the position checrfully enoucrh, cracked jokes at any one's expense, taxed onc another with having forgotten to pay the washerwoman before starting, or with being the Jonah who was causing all the trouble. Then as the days wore wearily on, some of us felt very much inclined to cast lots to see who really was the Jonah and cast him overboard, but doubting the presence of whales on that coast with sufficient capacity to entomb any of us, the idea was never put into practice.

So as not to be too far from the land in the event of some irreparable accident happening to our very erratic engines, or to the well-worn hull that carried them, we kept close inshore, making the course as short as possible by steering from headland to headland and not coasting all the bays we passed. The first night out we lost nearly all the lubricating oil. The balance was soon used up in the engine-room, all the kerosene having been taken possession of by that department. Of course we were living on tinned meat, but before we had a show every bit of fat was rendered out of it for the engines. The same thing happened with the sardines 


\section{IN AUSTRALIAN TROPICS}

and all the tinned butter. I subsequently remembered that there were two cases of axle grease in the cargo. These were quickly dug out, and the contents used after having been mixed with the kerosene. It was not by any means an ideal lubricant, but having nothing else we had to use it.

On the night of June 24, wilen many miles off the land, the steamer having drifted out owing to a brcakdown, it came on to blow a vicious, bitter gale from the south-east, and raised a heavy sea. The engines once again being persuaded to go, we headed for the shore. At 2 A.Mr. the skipper called me on deck. What a cheerful outlook it was, to be sure! The night was intensely dark, the bitter south-easter right in our teeth, with driving rain, and our old boat wallowing about, creating a mass of white foam all around her. The decks were constantly awash. When I reached the skipper he yelled in my ear, 'It is all up with us, we cannot make the land.' I might mention that we wore nineteen all told on board, ten of whom were Europeans. The skipper and I settled that at the first sign of foundering the Europeans were to take possession of our one small boat, and in it to try and weather the gale. If the worst came to the worst it meant a fight for life, and probably bloodshed, so I saw that my revolver was in good order, and kept it at my belt the rest of the nicht. Ilowever, it was destined that such a contingency should not arise, for the engines held together sufficiently long, and the gale taking off a bit, we managed to strugrgle under the land at the Blyth River. 
All this time the pumps were at work, for this iron steamer was leaking badly. The engineers took advantage of the spell and tied things together again. Our fresh-water supply being nearly exhausted, a party landed to search for some, but did not succeed in finding any.

We made a fresh start at daybreak on June 26 , intending to run through Brown Strait. Owing to the south-east wind and heavy sea this was not deemed safe, so a course was shaped for Cape Wessel. Keeping well under the lee of the islands for shelter, we passed the cape soon after miclday of June 27 , and then felt the full force of the wind and the accumulated strength of the long rolling waves which had gathered force in their passage from the other side of the Gulf of Carpentaria. The result was that our engines at once refused duty, and we lay there, tossing about at the mercy of the wind and waves.

Amonerst our passengers was one whom I will call the 'selfish man.' During all our struggles he never once offered any assistance, and would collar any man's tucker to save himself the trouble of getting it himself. When we broke down off Cape Wessel, where the steamer rolled so badly that it seemed she would turn turtle at any moment, I made a snug place where I could jamb myself while I fed. I then crawled to the locker and secured some tucker. Upon my return I found the selfish man had taken possession of my snuggery. It was just what I wanted-an excuse to use strong language to somebody. I doubt if the selfish 


\section{IN AUSTRALIAN TROPICS}

man ever before had heard such a variety of elegant names and phrases. I wound up by threatening to chuck him overboard if he did not shift promptly, and I was in such a towering rage that I believe I should have attempted to put my threat into force if he had not done as requested. Repairs had hardly been effected before the eccentric broke, but the engineers connected the other one, so we were able to keep the engines going. There was the disadvantage that we could not go astern, but had to keep moving ahead. By this time our fresh water was just exhausted. We discovered that one of the tanks leaked, while the wretched cook had been extravagant enough to boil the spuds in fresh water. We accordingly resolved to put into Melville Bay (Gulf of Carpentaria), where I knew the Malays had a campingground (Limba Pandria), and get a fresh stock. On June $2 S$ we anchored in the bay, but not at the campingplace. We were not able to pull round to it on account of the strong wind and heavy sea. However, we were lucky enough when we landed to strike good water, apparently permanent. As fresh nigger tracks were very numerous we kept a sharp lookout, but we did not catch sight of any aborigines. As the engineer feared our stock of coal would not last much longer, it was decirled, when we started on June 29 , to shape a course inside the islands, so that we could have a little protection, and if necessary scek a sheltered spot and cut firewood. Soon after starting, our cranky old engine jibled acrain. We had to keep clear of the land, so there we lay with a nasty scil and thick heavy weather, drifting 


\section{MORE TROUBLES}

to leeward, while the engineers were straightening matters for another start. Repairs were cffected at daylight on June 30 . We kept going nearly all day, and then something else went wrong-the air-pumps and piston-rod this time. We managed to get under the land, and anchored off Chasm Island. The engineers were busy all night and part of the next day repairing, and we made a start about midday for Connection Island, inside of Groote Island, where we anchored at sundown. That night I had a great haul of fine red schnapper. Our water was finished, so we landed on the island next day (July 2) to hunt for some, and at the same time to cut wood. By digging we found a little fresh water, but it was thick and muddy. We kept at the wood-cutting all day.

I noticed some very pretty orchids on some of the trees, but had other things to attend to than go botanising.

The intense heat and the bad water did not make things cheerful. Then we had to get the wood into the boat, which was not pleasant work. The island was surrounded by a coral reef, and there were some hundreds of yards of this to walk over. Then we had to wade out into the water on account of the surf. It was awfully hard work, and the coral cut our boots to pieces. While we were on shore the cook's galley caught fire, but before much damage was done the flames were got under.

The selfish man again became apparent. He would not cut or carry wood, nor dig for nor carry water, but simply loafed. It was dark when we again reached the 


\section{IN AUSTRALIAN TROPICS}

steamer, weary and worn out, but ready for our food, for we had not had any during the day. Fish had been cooked for supper for the shore men, but the selfish man had made such inroads that we had to go short.

Another start was made that evening. We shaped a course for Maria Island, on the mouth of the Roper, and next morning reached the little bay where the Springbok discharged some coals in I87I or I872. To our great delight we found that the coal, which had lain for some fourteen years exposed to wind and weather, shine and storm, had in no way deteriorated. We set to and shipped about five tons, having to carry it down to the boat in brandy cases. It was nice sort of coalhumping. Snakes and centipedes seemed to appreciate that coal heap as a dwelling-place.

On the morning of July 4 we stood across to the mouth of the Roper, and with the assistance of Mr. Pinder, who I have mentioned had been on the river for some time in the Young Australian, we speedily found the channel, entered the river, steamed twenty iniles, and anchored. The engineers immediately cominenced to repair the usual damages, besides which there was something wrong with the shart. Next day we steamed up the river until within about three miles of the Wilton. We ran on a sandbank, which convinced us that being in a steamer that could go astern was rather an advantage. We kedged her off all right, however. Next day the steamer was taken up to within four miles of I.cichardt's Bar to discharge careso. We were here four days discharging and repairing darnages. 
The delight of being able to revel in an unlimited supply of fresh water after many days of pickle was something to be remembered.

The bunker lid being off one day, I saw daylight through the ship's side for a space of over a foot in length. This could only be stopped by building a trough and running cement in. Whenever the steamer stopped we could hear the water running into her from the stern gland. Several sore places were discovered, but by dint of keeping the pumps going we managed to keep the boat fairly free of water.

During that time I stopped principally at the shanty at the Bar, where there was plenty of life. A constant stream of overlanders, comprising good honest men, brumby hunters, cattle duffers, horse thieves, and nondescript outlaws, were passing through, it being in the height of the Kimberley rusin. One of these, Mr. Hugh Fraser, took telegrams from me to the Elsie for Port Darwin, to ease the minds of our friends, for we were twelve days overdue, and owing to the constant stream of people, word would quickly have reached them if we had arrived at the Roper. Police were stationed at Mount M'Minn, and the store was now licensed, so things were not exactly the same as when I previously visited the Bar. The old stcrekeeper was dead, and another reigned in his place. I saw Fraser buy six tins of curry powder; when he had departed the storekeeper told me the contents were rotten-cheerful for Fraser when the time came for him to make himself a nice savoury curry. The storekeeper, who thought he 
had done a smart thing, was a kind of mean beggar. In fact, he was the selfish man I have referred to. I remember him in Darwin once entertaining in one of the hotels a lady passenger by one of the China boats. On his asking what she would have, the lady replied, 'I think I'll take a glass of wine.' The mean man, who was Scotch, rejoined, 'I 'll no' shoot champagne.' No backblocker would have behaved as he did.

Brumby hunters are wild horse hunters. These men run down the wild horses, break them, and sell the animals as opportunity offers. They sometimes take a mob of brumbles into Queensland. They lead a wild and dangerous life; as a rule the niggers fear them, and from what I heard they had reason to. This occupation often leads to horse and cattle stealing. It has been put to me several times, and I believe it is true, that the genuine cattle duffers are fine, hearty, athletic, well-educated, big-hearted men. They would never rob a poor man, and never refuse to help a ncedy traveller. They have been known to give horses to hard-up men. These free-and-easy characters did not consider cattle and horse duffing on a large scale from wealthy station owners a crime. To justify their conduct they would say that So-and-so's father made his money and acquired his station and cattle by similar means in former years. Any man camping with these gentlemen would be most hospitably treated. It was not safe to camp a few miles away from them. They used to make raids on different stations, usually at the end of the wet season, and run off with a few hundred head of cattle from each, on 


\section{CATTLE DUFFERS}

to a large tract of land in the ranges between Settlement Creek on the border and Anthony's I arroon in the tablelands. They bred from branded horses and cattle, and sold the young unbranded stock to some of the lagoon or reformed cattle stealers in Queensland, who had acquired a piece of land and a registered brand. These cute men always camped some distance from their stock, and worked them with nigerers, so that it was difficult to connect them with the stolen stock. Branded cattle were seldom sold by them in any great numbers, unless through some one who was supposed to be fairly respectable, by whom they were passed to the Lagoon or Clay Plan squatter.

I could spin pages of yarns about the sayings and doings of the fellows camped there, but it would not do. I must mention some of the characters, however. There was one man who only removed his trousers when old age necessitated a new pair. This happened while we were camped there. Having secured a new pair, he went to the river at dusk to effect the exchange and have the usual trousers wash. On a sudden he stepped on to what he thought was a log, but it was a big alligator. I cannot say if it were disgust or surprise, but the 'gator cleared like a flash, and the man got such a start that he did not get over it for some time.

One of the fellows I met, the 'Queensland Orphan,' a member of a strong gang of cattle duffers, therefore on the cross, had greatly distinguished himself by perpetrating one of the coolest pieces of barefaced robbery that 


\section{IN AUSTRALIAN TROPICS}

can be imagined. There was a constant stream of overlanders from Queensland bound for the Kimberley goldfields in Western Australia. At that time the only route after passing the Queensland border was over Settlement Creek through the $\mathrm{M}$ 'Arthur and the Roper, thence to the Elsie and onward. Well, this scamp settled on one of the stations at the bottom of the Gulf of Carpentaria, built himself strong yards, and put up a shanty. From that and the adjoining stations he helped himself to the fat cattle necessary for a butchering business. He did a roaring trade and was making money fast, when the station managers expostulated. The butcher man said he would see them somewhere before he would shift. There were no police within three hundred miles. At last he offered to sell the goodwill to the station men for $£ 300$. I don't think the deal came off. The Orphan stuck to his business until he heard the police had arrived in the district, then he made off.

This reminds me of another little bit of killing business which took place on a station in the Gulf country. Two men called at the station, were well received, and treated with kindness. When leaving they were given a good supply of salt meat. To show their gratitude, soon after leaving the homestead they shot a beast, cut out a piece of the rump, and left the balance.

We just missed the 'Ragged Thirteen,' a notorious party of hard cases, who were working their way to Kimberley on the 'Never Never,' which means that this batch of ruffians were simply working their way over to the rush by robbery. I expect if such men carried 


\section{PADDY THE PRIEST}

on in America as these men from Queensland to IVestern Australia did, Judge Lynch would have had a say, the: result bing an ounce of lead or a few feet of rope. $A$ s it was, I often wondered that the lead dic! not eventuate.

There was a rery cute customer called 'Paddy the Priest.' Ite had a contract to deliver a large number of cattle at a station, having to find the men and plant himself. All his hands left him, but he was equal to the occasion. At all the old cattle camps there was gencrally a great number of empty meat, jam, and fruit tins. Now, Paddy collected these and always dropped a certain number at each of his camps when leaving. The drovers' men coming behind concluded that he was feeding his men like fighting-cocks. If their bosses refused to do likewise, they plassed on to Paddy. They soon discovered that Paddy was above supplying luxuries, even sugar.

Many an hour I sat smoking with those fellows, who were mostly gentlemen of a sort, and listening to their yarns. One was almost led to believe that each one remembered every beast he ever saw or handled. It would be, 'Bill, you remember the time I near perished the brindle cow', etc., or, 'You remember when 'Arry was kilied by the niggers, the black bullock ...., and so on. Then the yarns would drift on to horses and horseracing generally, accompanied by some extraordinary experiences, which they simply treated as a matter of course. With one or two exceptions, the men used most elegant and appropriate adjectives. In some cases nothing offensive was intended, the blue words being simply 


\section{IN AÜSTRALIAN TROPICS}

put in because it was the custom. Others used the words as terms of endearment, while some did so because they liked the flavour of a good, round, ghastly oath. I shall always remember how the old boss of the store used to ask for things at table. Innocently as possible he would say, 'Pass the something mustard,' or 'blessed salt,' or 'Send along the ruddy gore vinegar.' Of course we irrigated, and each one in his turn would use his pet invitation, 'What's your poison,' 'Lct's liquor,' 'How about wetting the whistle,' or 'Let's wet the other eye.' Occasionally it would be, 'Mat, it's your turn.' Mat was the man who sold the stuff. He generally came up to the scratch, and it paid. Mat always gave me 'top shelf' stuff. He considered it casier to do so than try and palm off some villainous compound. And he was right.

To be a successful shanty-keeper a man must be able to shoot, fight, and ride well. He must also be a good bushman and gambler. It is necessary that he should have a knowledge of the handwriting of the station owners and managers in the district.

As a rule, vile liquor is sold in the shanties. Accounts are rarely kept of the drinks consumed by the customers. There it is, help yourself, as much as you like, and as long as you like, that is, of course, if you have first handed in your cheque, and consequently, 'your breath is sweet.' The cheque having been knocked down, the outfit follows, ending generally in a fit of delirium tremens, from which some recover, but many don't. These shanty-keepers out back were, in my time, a terrible 


\section{BUM-BOATS}

curse, not alone to the poor bushman, but to the squatter: on whose country they settled, for they were the means of drawing numbers of cattle and horse thieves about the place. I knew the owner of a station who was thus afficted. Ile tried many means of getting rid of the shanty-man and his wife-a bad lot, the pair, regular outlaws-but failed. As a last resource he put a fire-stick into the tent and brush buildings, the whole lot being burned with the stock of spirits and ale. Floating gromshops, or, as they are called, bum-boats, were another terrible infliction.

Two men, with a van and pair of horses, a rum and whisky cask, and some chemicals, would travel through the country, visiting the stations and cattle camps, and sell the vile compound. They would also gamble and indulge in any little villainy that would rake in the dollars. They were never known to run short of grog, yet they never received any. They manufactured it themselves at great profit, but at the cost of many a life. As can be imagined, great sprees and drunks often eventuated, especially at race-meetings. It would be drink, drink, for days, perhaps weeks, until every drop of intoxicating liquor was consumed. The after effects would be terrible. Recourse would then be had to every imaginable drink, such as Worcester Sauce, Friar's Balsam, Pain Killer, until that supply was exhausted. Some of the poor fellows would finish up in delirium tremens, with others bordering on them. Men in their sane moinents would tie themselves up to a tree at night, others would hopple themselves, fearing that they would 


\section{IN AUSTRALIAN TROPICS}

wander in their mad moments into the bush and be lost. It might be considered strange that persons like those mentioned should be allowed to settle on the stations. Take into consideration the vast size of many of the stations, sixty to one hundred and fifty miles across, then the difficulty of dealing with the trouble will be more readily understood. Nearly all the tracks and roads pass through station property.

To give some idea of the endurance and suffering undergone by some of the cattle men, I will mention an event that occurred in the Gulf of Carpentaria country. The niggers had been playing the deuce with the cattle; so a party went out to expostulate. During the argument the manager of the station received a very severe wound in his chest from a large stoneheaded spear. After considerable suffering and trouble he reached the Roper on his way to Darwin for medical assistance. It was a case of something like nine hundred miles to see a doctor. When starting from the Roper the poor chap was thrown from his horse, and had a leg broken a day or two before we arrived. After a rest of several weeks he made another start, the leg being very much out of shape. The sufferer eventually reached Darwin, and left by steamer for the south. When I said good-bye I most certainly never expected to see the m.m ayain, but in six months he was back, cured, and his leg straight.

Corporal P'ower, who had his camp at Mount M'Minn, invited us out for a change. We started out in a tremendous dogr-cart belonging to our host. IVhen passing through 'Itell's Gate' every spoke in one of the wheels 
flew out, and we all came a cheerful cropper, but nobody was hurt. I might mention that IIell's Gate was paved with boulders. Poor old Power, who has gone into the 'great beyond,' was one of the finest bushmen who ever crossed a horse, and one of the best fellows who ever lived.

When about three miles from the store we noticed a sheet of iron in a tree, on which an immense hand was painted, together with the intimation To the Sture. The tree was alongside the overland track, and the hand faced the direction from which all travellers came, viz. the M'Arthur. The artist evidently did not remember, or did not know, in what direction the hand had to face, for it pointed right into the bush and away from the store. The storekeeper would not have another sign painted, for he explained if travellers went into the bush as indicated, they would soon find out that there was no store, and therefore would naturally turn round and try in the opposite direction.

Having done all we could to the steamer, a start was made for the M'Arthur on July II. We were brought up short by running on a shelf of jagged rock near the Wilton. If this had happened a length ahead it would have ripped the side out of the steamer. We floated off at high-water, and resumed our voyage. However, we were on discoveries bent, for that same evening we ran on a sandbank where the chart showed three or four fathoms. We tried hard but unsuccessfully to get the steamer off, and had to wait six days until the tide floated us off.

During the time the Ellengowan remained aground in 


\section{IN AUSTRALIAN TROPICS}

the Roper our position was extremely uncomfortable, for owing to the very sharp lines of the vessel, she lay on her bilge at an angle of forty-five degrees, and everybody had to crawl about on hands and knees. We sat on the outside of her to have our meals. The master, to occupy the minds of the crew, I suppose, started them chipping the sides of the vessel. One chip was sufficient, for such a flake of rust came off that it seemed as if the whole side would follow.

Before we left the landing, where all the cargo was lying, by some mysterious means a case of preserved meat found its way on board. If it were ever missed, no doubt somebody else got the credit, for there were plenty knocking about who deserved it. It may have been the English swear words, used by the Chinese cook when he fell down the cabin steps with that case on his shoulder, that caused the meat to go so quickly, for go it did. It transpired that this was all there was on board, so we were soon on the short commons of tea and flour. We made repeated excursions ashore, but had poor luck with the game, which was very scarce for some reason at that time. Our bag was one kangaroo, a native companion, and several pigeons.

To get within shot of the pigeons I had to work my way through a belt of mangroves, and then on my stomach crawling for some distance over 'devil devil,' or Bay of Biscay country. The pigeons were worth the work.

During nne of our walks ashore we sighted some niguers, who rushed away at once. However, we 


\section{A BUSH FIRE}

managed after a great deal of hother to make friends Onc old man was full of 'Bungawah Lowrie. Captain Lowrie was in command of the steamer Young Australizu which was wrecked, and which I mentioned in a previous article. We were walking along, when all at once the old man caught hold of me and hauled me back, saying, 'Look, Bungawah.' Another step and I should have been on the top of an immense yellow snake, the bite of which, as far as I could understand, was very bad. It was the snake, however, that went this time, for I shot its head off. The old man immediately annexed it, no doubt thinking that bungawahs are useful at times. I did not begrudge him the snake. Bungawah means boss, captain, or chief.

I think one of the best fires I ever started was near where we were aground. Pinder and I were wandering round looking for something for the pot, when we struck a patch of jungle. The country adjacent had evidently not been burned for years, for there seemed to be feet of dry undergrowth. The temptation was too great, so a match went into it, and we cleared. It was a truly wonderful sight. The evening was perfectly calm, a wall of flame about fifty feet high rose up and it soon spread quickly, and cleared the ground for fresh growth. In country where the tree fern (Cycas media) grows plentifully, after a blaze you get a very good idea of the rejuvenating properties of fire. Immediately after it is burned you can see nothing but black posts all covered with beautiful green caps formed by the fronds of the palm.

A bamboo jungle on fire is a grand sight, and the 


\section{IN AUSTRALIAN TROPICS}

noisc made by the bursting of the hollow sections of the bamboo can only be compared to what one could imagine the rattle of musketry in a big engagement would be. Another plant to make a big blaze is the Pandanus (screw) palm. On the calmest of days set fire to a clump of these palms, and the roar and rush of the flames would make one imagine a furious gale was raging. In the dry season the vegetation is generally fired by the natives for hunting purposes. I have seen some forty miles of country in a blaze at once. This conflagration was started by the natives. At night it presented a grand spectacle. Every now and then the flames, when they struck a patch of screw palms, or ran into a dried-up lagoon containing withered reeds which towered up many feet, would soar to a great height. When out hunting we often started fires to clear the country of the grass, which generally ran from six feet to ten feet high. We were always perfectly happy when we originated a blaze, because we had the knowledge that we were too far away from anywhere for the fire to do damage.

On July i $S$ we steamed down the river for a bit, when it was discovered that the shaft was bent, and that the bearing supporting it had nearly worked its way through the side of the ship, and consequently had to be cut rirrht away. The shaft being bent no doubt explains why the bearings were not bolted down in the first instance. After this little matter of detail had been attended to, we stcamed out of the river to Maria Island for more coal. While at the bar a quantity of Leichardt pine was cut 


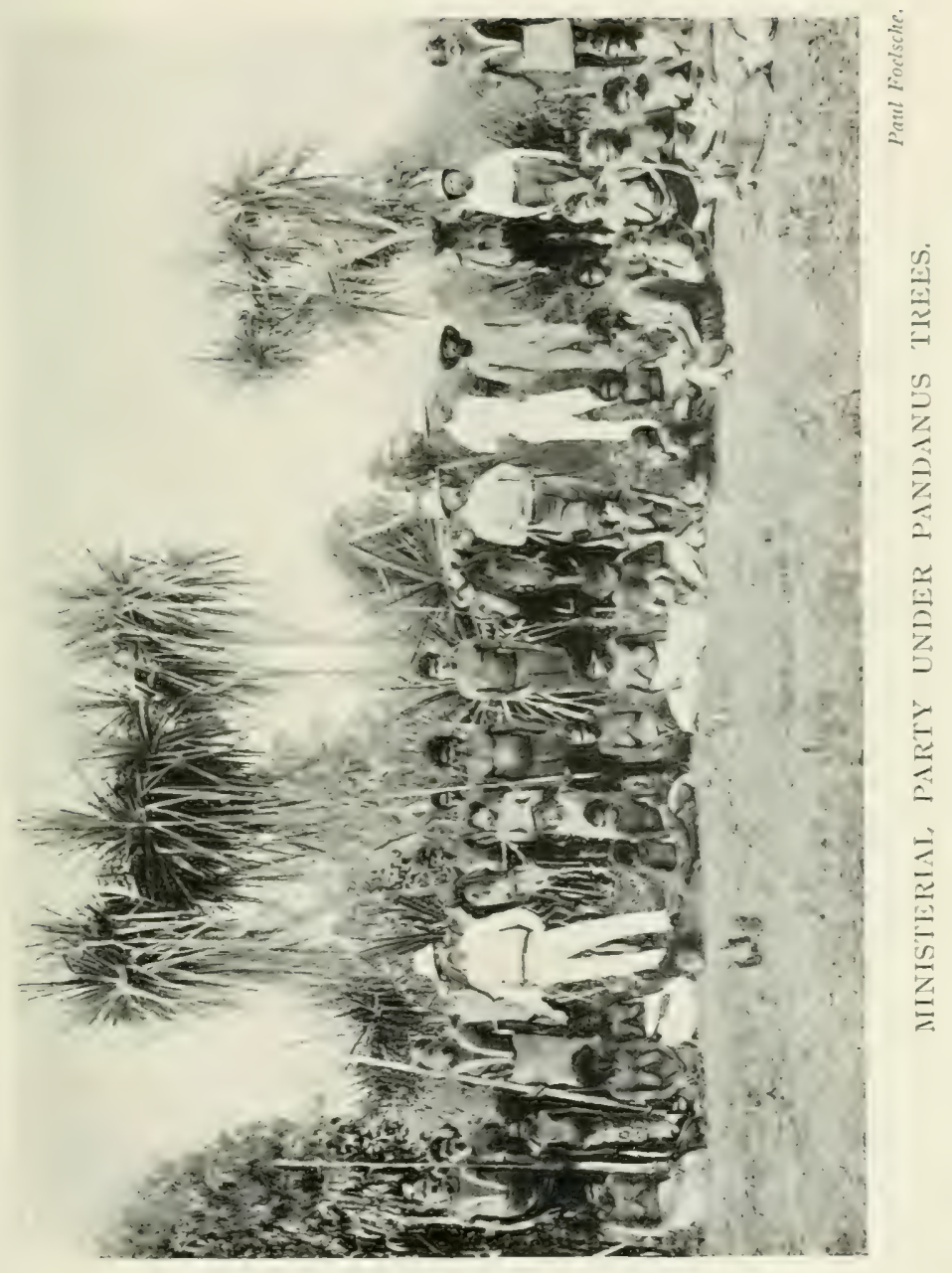



and taken on board for use in the furnace. How pleased we were to find that it would not burn! It was all thrown overboard. This pine is remarkably bitter, and excellent bitter cups can be turned out of the timber.

In readiness for the coal a lot of canvas bags had been made, so it did not take us long to ship ten tons. I thought bags were better than brandy cases for carrying coal.

While on the island we saw immense numbers of bronze-winged pigeons, and that was our share of them. On the morning of July 20 we anchored off South-West Island, at the newly discovered entrance to the M'Arthur.

In spite of the fact that all hope of catching the Budgarce had gone, we immediately started in the steamer's only boat, a small dinghy, with six persons, blankets, provisions (such as they were), etc., for the township of Borroloola, a distance of forty miles. To get into the river we had to carry the boat for about half a mile over a very soft mud flat. When I was at the $M$ 'Arthur previously we used another entrance, the one opposite to Centre Island. Consequently the river for a considerable portion of the way was new to me. Foolishly, we did not take the tracing of the new entrance with us, for there was one on board; so we were not sure whether we were in the proper entrance. We pulled all day long, and still I did not recognise any landmarks. During the afternoon a nigger hailed us from the left-hand bank, yelling, 'Borroloola, trrrr; Borroloola trrrr,' and pointed in a certain direction. We were cross and tired, and would not take any notice of 
the black fellow; but we were sorry enough afterwards for our indifference. I recognised the man as one I had met before on the river, and a most extraordinary-looking fellow he was. If you stood at the back of him squarely you could see him looking round the corners of his head without moving. For feet he had heels only, the rest of the pedal extremities, I suppose, at some time having been burned or cut off.

We pulled on and on until 9 o'clock at night, and realising that we were in narrow waters, it came to us as a shock that we were where we ought not to be. In fact, we were bushed in Batten's Creek. There was nothing for it but to land, which we did, and hauled the boat up a little. It was decided to camp on the top of the bank. One of the passengers said he was going to walk to Borroloola. We told him he could walk to Halifax if he liked. He started into the bush, and we rolled ourselves up in our blankets, dog tired, careless of niggers or anything else. Some time afterwards we heard the steps of our mate returning, and then a crash of branches. He had apparently walked over the bank, but with great presence of mind he yelled, 'I am going to sleep in the boat.' At daybreak we roused out, perishing with cold, for our blankets and clothes were wet through with dew. The only tucker we had was a sort of bread, so seeing some 'galares,' I had a shot at them, and knocked one over. O the discrust! for not twenty yards away in the grass had been a great flock of Burdekin ducks, which we had not spotted. My shot, however, settled the matter. I 


\section{CYPRESS PINE}

picked up my bird and soon had it in the coals. While cating it I told the other fellows if they wanted game for breakfast they had better hurry up and get some.

During our journey up the river I noticed some fine patches of Cypress Pine. I am not certain if I have mentioned the fact before, but this timber is very valuable, inasmuch as it is white ant proof-in fact, it is the only timber known which those pests respect. It is short-grained, rather hard to work, and full of resin of a highly aromatic character.

We pulled back for some hours, during which time we had a try at another opening, but it proved a cul de sac, and were just making up our minds to try and reach the steamer again, when the Malay boy cried out, 'I see schooner,' and there, sure enough, she was. Now we realised how it was that we had made such a howiing mess of things. Just before reaching it on the way up, Pinder and I were pulling and Copeland steering, and to avoid a reef of rocks Copeland had hugged the right-hand shore, thus opening out the broad entrance to Batten's Creek, which we thought to be the continuance of the M'Arthur. If anybody had for a moment looked up, the schooner would have been seen, but when the other side was made she was shut in. If we had only interviewed the nigger we would have saved ourselves a fifty miles pull. From where we camped Borroloola was only about seventeen miles distant. The sight of the schooner put new life into us, and we made the dinghy hum over the three miles to where the craft was anchored. This was the spot where old M'Leod 


\section{IN AUSTRALIAN TROPICS}

was camped the year before. I immediately boarded her, put the broad-arrow on the mainmast, intimating that I seized her in the Queen's name, and with almost the same breath said, 'For God's sake give me a bottle of beer.' The beer was forthcoming, and good it was. I found that I knew the master well, he being an old Port Adelaide man. The mate was also the owner of the ketch. He only had a coasting certificate, and had to ship a deep-sea master when he left the colony in which his certificate was issued.

There was a number of passengers on board, several of whom had fever very badly. In the little cabin was a poor woman unconscious, a victim of fever. This was truly a most pitiable case. She had left her home in Queensland to nurse her daughter, the wife of a manager of one of the stations on the tablelands, through a sickness, and when on her way home was struck down with malarial fever. The poor woman died two days afterwards, while the ketch was still in the river.

After a good night's rest I entered into business, and found that the master was solely to blame, the owner of the craft being at his mercy. This, in conjunction with the fact that she had so many fever patients on board, decided me to inflict commensurate fines, covering all our expenses, which the owner gladly paid. He had to sell a large quantity of stores to raise the money. Fortunately he had plenty, and it was easy to get customers amongst the out-back people camped on the bank of the river. I must say that he treated us royally during our stay on board, and we were fit for good 


\section{A STATE OF CHAOS}

tucker. The day after our arrival, Ceppeland, a Malay seaman, and the two passengers started for the settlement with the mails. Next day Copeland returned with the Malay, and reported that the settlement was in a state of chaos, owing to the absence of police, and for hundreds of miles round the M'Arthur the district was in a state of terror. This was no exaggeration, for the crimes committed were beyond description. All the outlaws of Queensland made for the Territory, for they had nothing to fear; in fact, this country was a sanctuary for every ruffian in Australia. Just before we arrived an unspcakable crime had been committed in broad daylight in front of one of the stores. The man in charge of another store offended a mob of these ruffians, so they stood off a few yards and emptied their Winchesters into the building, regardless of the fact that a man was there. He escaped from what almost might be regarded as certain death by throwing himself on the ground behind a galvanised iron case. I was told it was a common practice for these outlaws to blaze through a store like this if they were not satisfied with the treatment they received from the owner.

It must be remembered that in these out-back places the population was entirely floating, here to-day and gone to-morrow. Numbers of the fellows, many good, honest men, came in from out-beyond with large cheques, great hardships and privations having been undergone to earn the money. That was the shanty-keeper's opportunity. Unless the unfortunate fellows were staunch tectotallers they had a poor chance of getting away 


\section{IN AUSTRALIAN TROPICS}

until they had been lambed down to the last penny. Then they could go to Hades. Needless to say that shortly after this a magistrate and police were stationed at Borroloola, to the great satisfaction of the respectable residents and travellers.

Malarial fever was very bad on the river.

The owner had brought from the settlement for the use of our boat a quarter of beef. On account of the hot weather it was necessary to salt it down at once, which Pinder and I did, with the assistance of some station people who were camped on the bank of the river. The local residents also supplied the salt. I might mention that duty on the cargo landed by the ketch had been collected for us at Thursday Island; also that there was no connection between my man of the previous year and this craft. On the morning of July 23 the Budgaree sailed, and we made a start for the steamer at 2 P.M.

Copeland and his men were done up with their long pull from the settlement, so Pinder and I had to do the first spell of rowing. We pulled until dusk, when we landed and boiled the billy. Then came a weary pull of several hours, the night being pitch dark. We got mixed up in some of the mangrove creeks, but an occasional glimpse of the Southern Cross let us know that we were making to the nor'ard, and therefore must reach the sea in time. It was weary, weird work, the only sounds, besides the splash of our oars, being mysterious cracking noises in the mangroves, and now and again the splash of some great brute tumbling into the river. Scon after midnight we reached the open sea, but we had no idea 


\section{A BAD NIGHT}

where we were. There was not a sign of the steamer. There was nothing for it but to wait for daybreak; so, having no anchor, an oar was driven into the mud and the painter made fast to keep the boat afloat, for we could hear the alligators wallowing and bellowing on the mud-bank adjacent. It blew from every point of the compass during the night, and heavy rain fell, so it can be imagined what a time we four had in the little boat. Three Men in a Boat were nothing to it. At daybreak we caught sight of the steamer some four miles distant. After a terrible struggle over the mud flats, having again to carry the boat for a considerable distance, during which journey I knocked over a couple of ducks, we finally reached the steamer, thoroughly played out. The captain told us that the barometer had fallen one inch during the night.

A start was immediately made for home. During our absence the engineers had been hard at work. Our luck seemed to have turned, for during the run home we had hardly a ripple on the water, and the steamer did not break down once. We brought a little fat from the M'Arthur for the engines. When off New Year's Island we spoke the schooner Griffen, but not a drop of oil could we get. We sighted a big school of black fish, which could, no doubt, have supplied the oil, but they didn't. We called in at the Revenue Station, Bowen Straits, and secured some kerosene and salt buffalo, and arrived home on July 29. Just as we were entering the harbour something went wrong with a pump in the engine-room. I shall ever remember Captain Macredie 


\section{IN AUSTRALIAN TROPICS}

for his skill as a navigator, and the untiring dexterity and energy displayed by Ben Griffey and Shaw.

The Ellengozvan, at the request of the South Australian Government, was inspected by some experts, and the remark of one of them after an examination of the steamer gives an idea of their opinion of the vessel. 'Good God! the idea of men going to sea in a thing like this.' Shortly after our return the Ellengowan was turned into a quarantine vessel, and plenty of pumping was required. Captain Marsh and the late Mr. J. H. Servante, who was my landing-waiter, boarded a steamer before it was known that smallpox was on board. So for several weeks these two had the Ellengowan to themselves. Soon after they were released, down she went in fifteen fathoms of water-the best place for her. 


\section{CHAPTER VIII}

TO THE EASTWARD AGAIN

EARLY in the years 1887 and 1888 I again visited Bowen Straits for the purpose of picking up the money collected from the Macassar proas. In the first instance I went in the Victoria, a smart launch, and for once had real good going. On the way home we ran into Port Essington to pick up some oysters. I there found a cutter which some weeks previously I had cleared for Western Australia. I desired to know what the skipper was doing so much out of his course, but did not press for information, for I had my suspicions that his passengers wanted a change of air, but were not desirous that the Darwin storekeepers should know exactly where they meant to seek it. Having sold the owner of the cutter some Malay rice, we said good-bye. Many months afterwards I received a letter from him from Dobbo. He sent me his papers, which had been endorsed by the Portuguese authorities, to the effect that the cutter was to get out of Dobbo. The old man got. I never heard of him again.

Being fortunate to strike the flood-tide round Cape Don, and the ebb through Clarence Straits, the trip 


\section{IN AUSTRALIAN TROPICS}

home only took just seventeen hours, a decided improvement on the wind jammer, poor old Flying Cloud.

Early in I888 I found it necessary to again pay a visit to the Gulf rivers.

This voyage was made in the Active, a small steamer neither fast nor powerful. Having called in at Bowen Straits and settled a dispute between Robinson and a Malay skipper, we proceeded to the Goyder River, where we landed Mr. D'Arcy Uhr, a well-known explorer and out-back man, and his party of timber cutters. Uhr also had a small cutter with him, and two Malays to man her. The timber to be sought for was Cypress Pine.

On our way to the Gulf our man nearly made a mess of things. He determined to go through the English Company's Islands by Brown Strait, so shaped a course accordingly. We struck a rock, by which means it was discovered that the Straits were round the next island. Fortunately, it was only the heel of the steamer which found the boulder. The next bit of excitement was caused by the coals taking fire. As a fire, it was not a great success.

The channel at the M'Arthur having been marked by the captain with tall mangrove sticks, we had no trouble in crossing the bar, and steamed to Carrington's landing to discharge our cargo. The weather up to this time had been fine, but now the rain commenced coming down in torrents. The rest of the distance to Borroloola, thirty six miles, had to be done in the ship's brat. A very cheerful pull it proved in the circumstances. 
The settlers were delighted to see us. All the grog and beer had been consumed, and there was only a quarter of a ton of flour left. The New Year Races and other contingent festivities had lasted three weeks-a good explanation for the dearth of liquids. The settlement had grown somewhat since my last visit in 1886 . Crime had decreased considerably. It is astonishing the power of a couple of good policemen, armed with the majesty of the law, together with good shooting-irons, which they are not afraid to use should they have to deal with a bad push. Trooper M. Donegan was the first policeman stationed at Borroloola, having been sent there irnmediately after my return to Darwin in the Ellengowan in 1886 . Of course I had to see him, as he was acting Customs officer. Donegan and his mate Curtis had had some lively experiences, but had evidently proved too much for the crowd knocking about at the time of their arrival on the scene. Donegan, who was a typical Irishman, fond of races and horses, made the trip to the Roper, overland, alone. He took six horses with him. When he reached Abraham's Billy Bong on the Roper he found the shanty and store had been burned down, the only thing saved being a cask of rum. Not being favourably impressed by some of the men congregated there, he decided to camp a few miles further on. When the horses were mustered in the morning, to his disgust he found that the best police horse, and his own favourite equine, a bit of a racer, had disappeared. Thinking that he might be able to gain some information, Donegan returned to the Billy 


\section{IN AUSTRALIAN TROPICS}

Bong. He had a drink and a yarn with the fellows there, but did not mention his loss. Upon his taking his departure again, one of the men offered to ride with him for a few miles. During the ride pleasant conversation took place. Having gone far enough, the man wished Donegan good-bye. No sooner had Donegan turned his back than a couple of bullets whizzed past his head. 'You — trap, did you think we had your horse?' yelled his late companion, who then put spurs to his horse and disappeared in the bush. Donegan gave chase, and emptied his revolver in the direction the man had gone, apparently without doing any damage. It is a good thing for that man that Donegan never saw him again. His great delight can be imagined when he had proceeded some miles to see his missing horses making towards him. Their hobbles had been removed. They had evidently been driven away to where some other horses had been mustered, but had made back to their mates. Travelling horses become great chums, and they can't be parted.

At the Roper, Donegan was joined by another trooper named Curtis, and a black tracker. During the journey from the Roper, Donegan met all sorts and conditions of men making for the diggings, many of thern, some up to sixty years of age, 'humping their bluey.' They literally carricd all their worldly belongings on their backs. A tramp of a thousand miles was neither here nor there with those men. On the sirle of the track one day Donergan saw a poor fellow evidently demented by hardship, who had dug a grave for hinself, and was 


\section{TROOPER M. DONEGAN}

continually walking round it. Donegan and his mate could do nothing for the poor fellow, so passed on.

The man I arrested in $I S 85$ at the M'Arthur for smuggling had reopened his shanty at that spot. However, as soon as the police put in an appcarance, he and his wife and followers cleared. The presence of police did not agree with the health of the men-I say men, for I am certain that the wife was different. She was a fine woman, and had often tried to get away from her husband, but he followed her like a sleuthhound. The man had a history, and if a particle of what was put to his record was true, he indeed was a bad 'un.

After Donegan had been at the river some time he wrote to me as follows: 4 No one knows or can realise better than I do the risk you and your men ran when you ventured up the river after the owner of the Good Intent. Had the overlanders arrived at the shanty, and your presence and intentions been known when you entered the river, it is doubtful if you would have lived to tell the tale.'

In a previous chapter I mentioned that a Queensland policeman followed up as far as Rosie Creek a man who committed suicide. It was close to the shanty that the Queensland policeman on his ruturn journey was supposed to have entered the river with the intention of swimming across. He was never seen again. An alligator was credited with his disappearance. It was generally understood, however, that he was assisted into the river.

The outlaws had a playful habit of making off with 


\section{IN AUSTRALIAN TROPICS}

the police horses. On one occasion Donegan and his trackers had to follow them a hundred miles before he recovered the horses. One day two Chinamen turned up at the M'Arthur police-station, and reported that they had been stopped at the Robinson River by three men who said they were Customs officers, and who collected $£ 20$ a head poll-tax. Donegan and his mate Curtis, a tracker, and one of the victims, left to pay a visit to the self-appointed officers. On arrival at the shanty the police party were received by twelve armed men, who threatened bloodshed if they were interfered with. Two of the men the Chinaman recognised. At a sign from Donegan, his mate and the Chinaman jumped behind trees and covered the crowd with their rifles. Donegan sang out, 'Shoot the first man who moves.' With that he and the tracker walked up to the crowd, revolvers in hand, disarmed the two men identified, and handcuffed them. $\mathrm{He}$ and his tracker then retired with their prisoners some hundred yards behind Curtis and the Chinaman. Donegan and the tracker then covered the crowd while Curtis and the Celestial retired. This they continued to do until some distance away. Having spare horses, the prisoners were mounted. A chain was passed round the horses' necks and then padlocked to the prisoners. The men in due course were punished. The other Customs officer (?) it was found was an out and out scoundrel named Monaghan. Some time afterwards this man was arrested at Corrella Downs Station for horse-stealing. A trooper named Smith had to escort lim to the M'Arthur. When getting ready to shift 



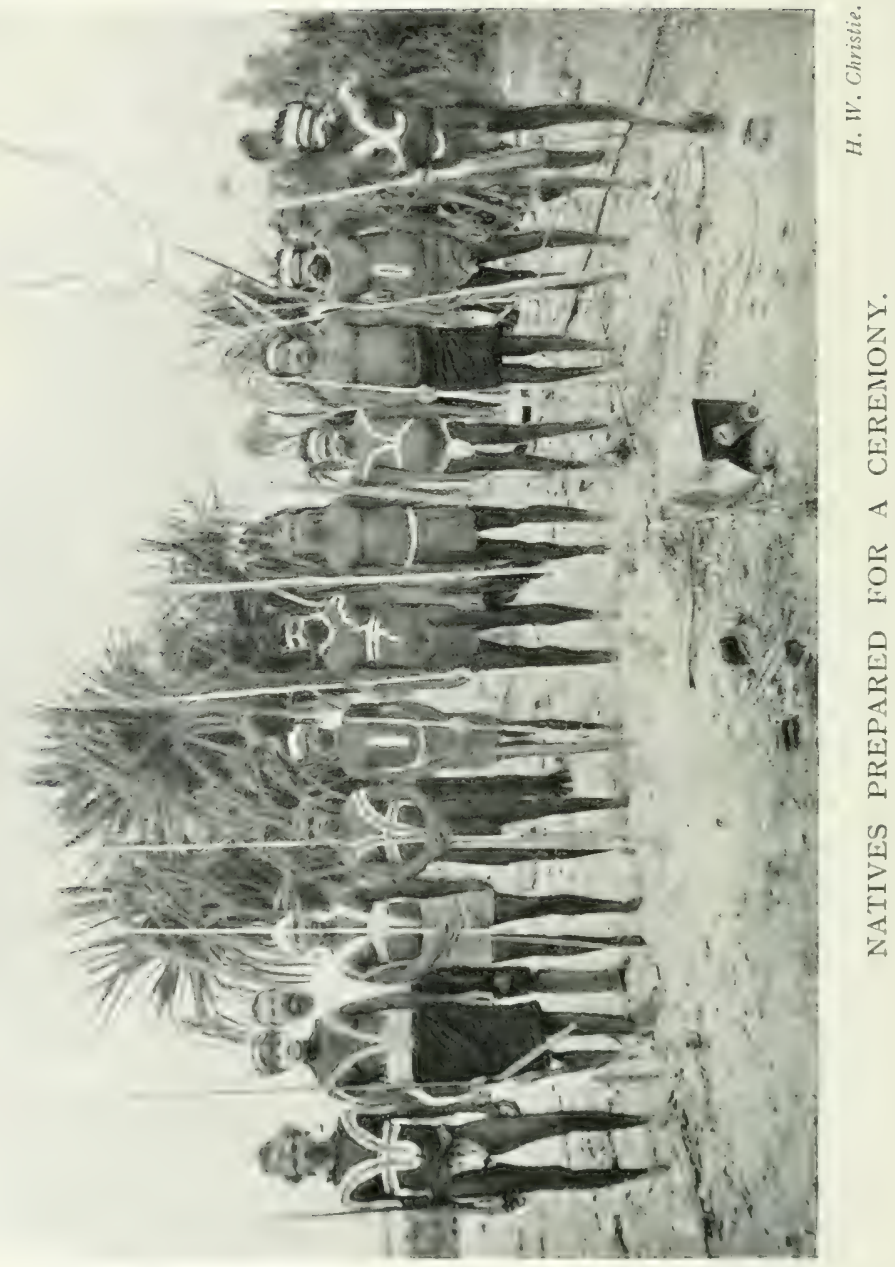




\section{OUTLAWS AND NIGGERS}

from their camp one morning, and while Smith was rolling up his swag, the tracker at the time being after the horses, Monaghan hit Smith over the head with a stick and stunned him. He then bound him to a tree and shot the black tracker dead when he came in with the horses. This fair sample of the outlaws knocking about the country at this time then made off with the horses, arms, and camp fixings. He has never been heard of since.

There were many murders by the niggers which the police had to look into, and which necessitated much travelling, sometimes with great hardships. There can be no doubt that many of the murders were caused by the white men taking away the black women from their tribes. Nearly all the drovers, cattlemen, and station hands had their 'black boys' (gins). No objection was raised by the black men to interference with their women so long as they were not abducted. It is the taking away of the women that has been the cause of so many white men having been rubbed out by the niggers. These women are invaluable to the white cattlemen, for, besides the companionship, they become splendid horsewomen, and good with cattle. They are useful to find water, settle the camp, boil the billy, and track and bring in the horses in the mornings. In fact, it is impossible to enumerate the advantages of having a good gin 'out-back.' The black women are, as a rule, well treated by those who take them. In the great outbeyond half-caste children never live. There can be no doubt that at times many of the blacks have been put 


\section{IN AUSTRALIAN TRÖPICS}

away by some brutes just for the fun of killing, by othcrs for revenge, but mostly the niggers brought the trouble on themselves by interfering with the cattle. In many of these cases no report ever reached the police. In one instance, so a man told me who was concerned in it, a whole nigger camp was wiped out. Some years ago I got a letter from a man who was attacked by the niggers in the Gulf country, and received some eleven spear wounds. He recovered. In his letter he said, 'I now shoot at sight; killed to date thirty-seven.' Thus it will ever be in developing a new country where the aborigines are at all hostile, and where there is no recognised authority to deal with them. A man who goes into the out-beyond country in a measure carries his life in his own hands. He may throw it away, as many do, or he may take measures to protect his life and property, which-to those who live where the law and police can always be applied to-may appear cruel and harsh. Not for a moment would I defend those who wantonly shoot down the blacks, but it must always be remembered that at times stern measures, and even shooting, are necessary.

One man, I remember well, boasted to me that he never carricd a revolver. He said he did all the punishment he wanted with a stock-whip and a wire-cracker. 'When I want to be particularly severe,' he remarked, 'I cut the top off a sapling and sharpen the remaining stump, bend it down, and drive it through the paims of both hands of the nigger.' That seemed awfully brutal to me, but that man assured me on his nath that he 
did it. I wonder whether the cruclty he practised ever came back to him in his struggle for life in the riverhe was drowned in the Katherine.

One afternoon a strange nigger reported to Donegan that a big mob of salt-water niggers were spearing cattle about twenty miles away. All the men in the settlement, except two who were left in charge, immediately made tracks for the scene of the supposed slaying of cattle. It was a case of supposition, for the guide, when near the spot indicated, disappeared into the bush, and that was the last the party saw of him. They could not find any niggers or cattle. It then came home to them that they had been properly done, and in a manner which evidently meant mischief to the settlement. They made back as if the devil were after them. It was a good thing they did, for close to the store were about three hundred able-bodied buck niggers all armed with spears. On the arrival of the party the blacks took to the river. The alligators no doubt had a good time.

Donegan gave me a few particulars of the selling of the booth in connection with the last race-mceting. The business was commenced by the drinking of plenty of whisky, the two publicans being particularly urged to wire in. Preliminarics having been arranged, the bidding started, and quickly went up to $£$ ro. Then the business was stopped, and another bottle of whisky consumed. Indeed, at each rise of $£ 10$, the auction was adjourned and a 'bottle of Scotch' put away. Eventually the sum of $£ 6 j$ was reached, and the booth was knocked 
down - not a bad price when the attendance might only be anything between one hundred and twentyfive and three hundred persons. No doubt the purchaser was on the right side of the ledger, however, when the long spree was over. One of the crowd present threatened to chain the police up. Donegan and his mate and tracker went to the public-house where the man who intended to do this deed was staying. Donegan sat down on a case and waited. The man rushed out and stamped on the policeman's foot. When the desperado, whom Donegan knocked down, recovered his footing and wind, his first words were, 'Police! Police!' He seemed to have forgotten that he had run up against an Irish trooper.

Donegan had a great surprise one day, when a man, whom I will call 'Tommy', and his wife rode into the settlement and demanded a divorce. They had ridden three hundred miles for the purpose. This was the pair who had had a fire-stick put into their shanty by a squatter because they would not shift. I knew the pair well. Tommy was a little thin fellow with a marvellous memory. I have known him read an article in a paper and then repeat it off word for word. Mrs. 'Tommy' was a tall, handsome, well-made woman, and a splendid equestrienne. Donegan was a Justice of the l'eace; he held all sorts of other offices. It transpired that the woman wanted to join another man, who was prepared to pay Tommy handsomely if the divorce came off. On Donegan explaining that, although he held many offices, the divorce business was a little 
beyond him, the woman exclaimed, 'If you don't grant it, so help me G-I 'll shoot him.' 'The best thing you can do. Good morning,' replied Donegan. Immediately afterwards he heard a 'bang, bang!' Donegan jumped round, and there was Mrs. Tommy blazing away at Tommy, who was jumping and dodging about, crying, 'Don't dear, don't dear.' The loving wife then barricaded herself in a room. As the woman would not open the door, Donegan got an axe and commenced operations. The cheerful party then fired several shots through the door, but did no damage to the axeman, although several bullets passed between his legs. The lady was arrested, and eventually taken to Port Darwin, where she was acquitted.

The same 'Tommy' was a very deceptive sort of an individual. There was a big fight on, and he was on the outskirts enjoying the show when a great hulking chap went for him. 'Tommy' backed and backed shrinkingly, crying out, 'Oh, don't; oh, don't.' When a little distance from the crowd the big man who wanted a fight must have thought the devil or a torpedo had struck him, for he was stiff. In two twos 'Tommy' had been all over him. He proved a nasty snag to run up against. 'Tommy,' although a bad 'un, was full of pluck. In that, amongst the crowd met with out-back, he was not an exception.

Donegan noted a peculiar custom amongst the black tribes inhabiting the Gulf country between the Roper and Normanton in Queensland. It seemed that they were in the habit of exchanging children with each other for the purpose of learning each other's language and 


\section{IN AUSTRALIAN TROPICS}

customs. Each tribe gave their children a sort of passport to the other tribe in the shape of a marked stick or bone. It almost looked as if it betokened friendly relations, because there were very few fights between the respective tribes. It was impossible to say how long this custom had been in vogue. Anyhow, it seemed as if in that system of education they were ahead of us with all our boasted civilisation. I noticed the other day that the proposal to exchange school-children with foreign schools had lately been mooted in England.

It may be considered that I have given particular prominence to the ruffians who, in such numbers, in the old days, sought sanctuary in the Gulf country and the out-beyond, where there is no police protection. The incidents related by me are true, so some idea can be formed of what the honest and law-abiding out-backer had to put up with; and being greatly outnumbered, they were obliged to submit to outlaw rule. Otherwise they would have incurred the displeasure and vengeance of the roughs, and perhaps had their property destroyed, to say nothing of having their lives endangered. Good, honest men are met with every day, and therefore need no description, but the crowd of outlaws I have spoken of were unique.

The few instances of dealing with the roughs may give some idea of the dark side of a policeman's life out-back. Still they had glorious times in that country. Just imagine starting out on a patrol for three or four months, with a dozen good horses well packed with necessary stores, and plenty of arms and ammunition. 



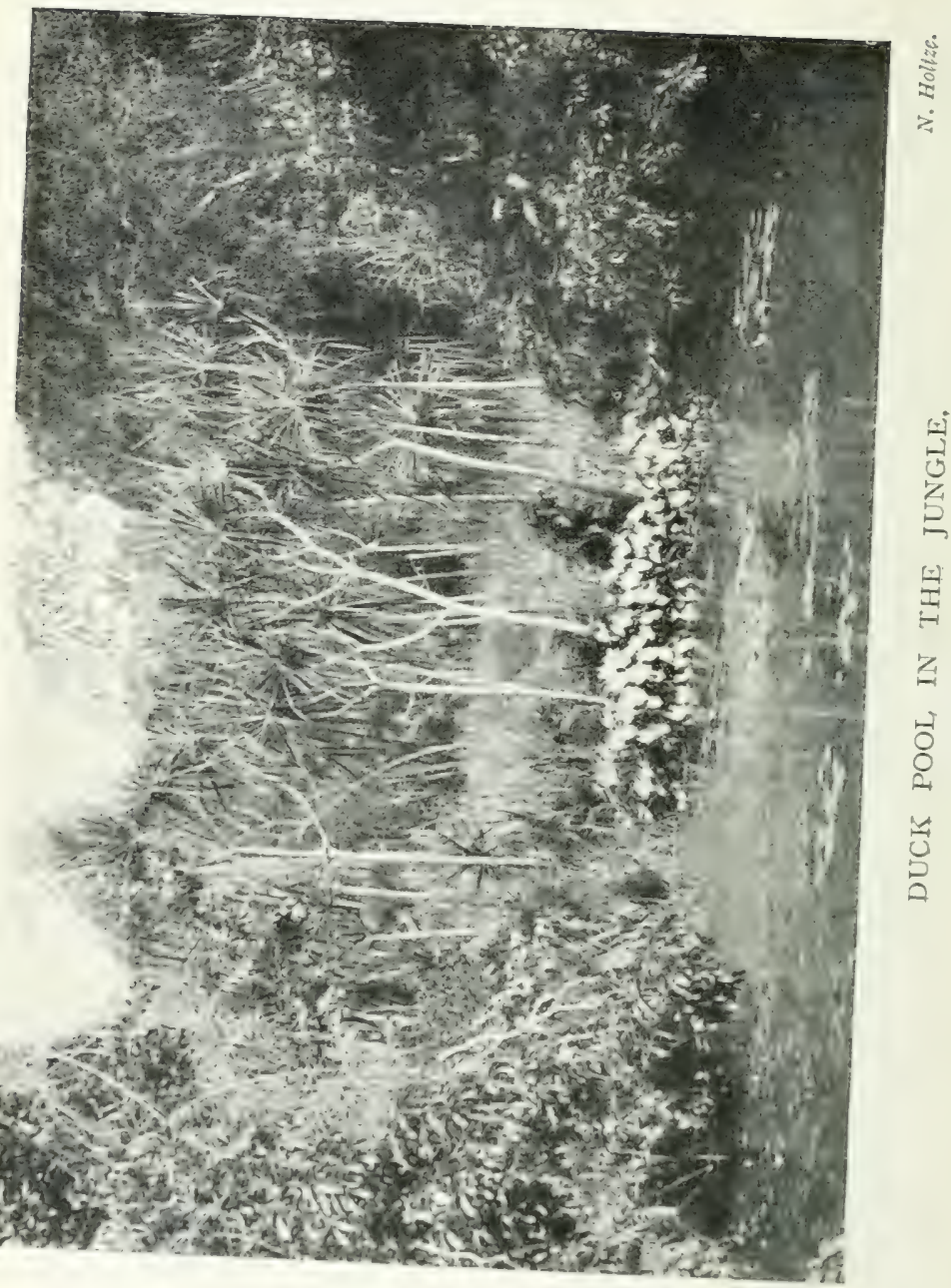




\section{A POLICE PATROL}

They did the journey in their own time, and were their own masters in every way. There was abundance of food and water for the animals, and a standing authority from the station owners and managers to shoot any of the cattle if beef was required. There was the certainty of a hearty welcome at such stations as they might call at. It was a charming and entrancing country to ride over, with new and interesting discoveries every day, the scenery being almost too beautiful for description. This was especially so in the early morning, when the sun, as it rose, lifted the mantle of mist and disclosed a magnificent panorama of beautiful trees, amongst which were the pandanus, cabbage palm, Leichardt Pine, paper bark, and fig. The large lagoons teemed with game and fish, and were always covered with lilies. The big winding rivers, well defined by giant trees growing thickly along the banks as far as the eye could see; the beautiful waterfalls, the grand valleys, the extensive, well-grassed plains, formed pictures which can only be properly appreciated by those who have been fortunate enough to behold them. The bounding kangaroo, the mobs of brumbies or cattle disappearing across the plains or into some valley, all lent enchantment to the scene. It is no wonder that men became attached to such a country. A free and independent life once expcrienced can never be forgotten. To me the outlaws seemed a desecration to such beauties of nature. It was a case of

'Where every prospect pleases,

And only man is vile.' 


\section{IN AUSTRALIAN TROPICS}

The life I speak of did not tend to reconcile troopers and other officials to the monotonous writing and redtape business; still they have to experience it afterwards.

It had been a very wet season so far, and the country was literally under water. An out-back squatter had just arrived, having walked or waded twenty miles through slush and water. He was on his way in for his mails, when his horses gave in. He just managed to get them on to a bit of hillock, and there left them. It was ten days before a party could get to the poor brutes, which were nearly starved to death. Having finished my work in the lively settlement of Borroloola, we made back to the steamer. The crew had been nearly eaten alive by mosquitoes. Two days afterwards we were in the Roper. The river was in heavy flood, consequently we had considerable difficulty in getting up to the bar. The water had been thirty feet, and was at the time fifteen feet, over the bar. When it was time for us to start down again, the trouble was to swing the steamer. Having had an interview with some of the trees on one of the banks, which carried away some top hamper, the skipper decided to let her go down stern first, until we should come across a bit of a back eddy which would catch her stern, and let the head swing with the current. This was successfully carried out. Just after we swung, a number of emus swam across the river. The niggers were after them, I expect. There being a heavy sea at the mouth we had to remain inside till the weather moderated. During the detention on one of the sand-flats we had a try with 


\section{ROPER MUD}

the seine. We enclosed a magnificent lot of fish, but when they felt the net closing in, they nearly all went over it like a lot of steeplechasers.

The mud at the mouth of the Roper is amazingly treacherous. It is apparently solid, firm, and glistening, but if you should trust your weight upon it, you are down to your waist in a moment. If you don't promptly throw yourself for'ard or get hold of something, it is hard to say when you will stop going down. When Pinder, my comrade in several of my trips, was mate of the Young Australian, the skipper had a lot of guide-posts, thirty feet long, nicely prepared, and with heads and struts. One was erected on solid ground, and answered admirably. The old man was told the beacons would never do in the mud, but he, never having tried what the mud was like, scouted the idea. So one was taken on to a spit, and after immense difficulty the pole was up-ended. During the work the men became covered with the mud from head to foot. It made them look like a lot of niggers. The pole commenced to sink; the struts, which had only been loosely bolted, spread out, then gradually turned up to the top, and the whole thing disappeared, looking like the frame of a gigantic umbrella turned the wrong way. The crew were recalled to the steamer by the skipper firing a rifle-at them, some said, but this he denied. If he did not fire the riffe at the crew, he fired something else when they got back.

Having cleared the Roper we went straight to the Goyder River, just picking up the immense banyan- 


\section{IN AUSTRALIAN TROPICS}

tree on the east bank at dusk, after having been absent seventeen days. This tree forms a magnificent landmark. Both going and coming back I had good luck with my Malay tow-line. The steamer did not travel too fast for fishing.

Upon entering the river we noticed a large fire on the beach on the western side, and also heard several rifle shots, evidently fired as a signal. I immediately went ashore. This necessitated a hard pull, as it was a dirty night, and the wind, being against the tide, raised a nasty jobble. Upon the beach I found Mr. Uhr and party camped. Mr. Uhr reported that the natives had murdered the two Malay seamen, and that the cutter was lost. Up to then no trace of the bodies had been found, so it was determined to make a search next day.

A nigger named 'Larrikin,' who was with the Malays in the cutter it appeared, stated that one day they had just entered the river, when the cutter was caught by a squall and capsized. The three men then swam to the dinghy, which was towing astern. As they got into the boat they saw some natives on the beach, who called to the Malays in broken Macassar dialect to come ashore, which they proceeded to do. When within easy range the niggers suddenly picked up their spears, which had hitherto been concealed, and threw them at the occupants of the dinghy, striking one Malay in the breast and the other in the loins. The men then jumperl overboard, capsizing the dinghy. The niggers again called out to them to come ashore, and they would not hurt them any more. 'Larrikin' advised them not to go, 


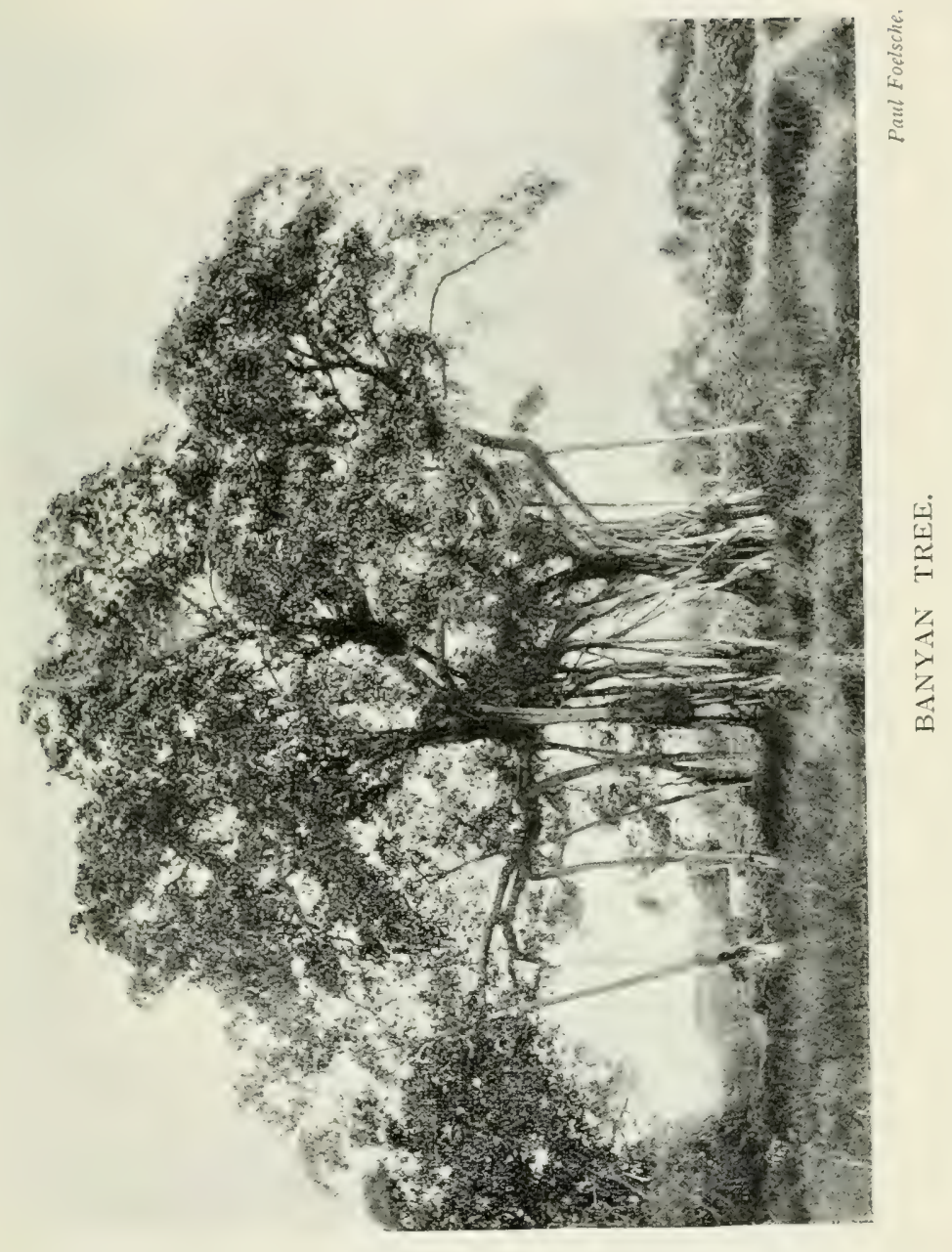



but to try and swim the river. In their wounded condition they could not do so, and made for the land. The niggers then rushed at them with mitpurdingos, and battered their heads in. 'Larrikin' immediately started for the opposite shore, a distance of thrce miles, the niggers, while he was within range, trying to spear him. In spite of the sharks and alligators he reached his destination safely. He arrived at the camp next evening, and the party at once abandoned it, leaving their tents, tools, and stores, and made for Florida Station. Mr. Uhr was absent exploring. When the cutter capsized, the Malays lost their firearms, or things might have been different.

At daybreak we started, and first landed at the large banyan-tree on the east bank, but after a thorough search we could not find any signs of the victims. We then crossed to the scene of the murder, which was pointed out to us by 'Larrikin.' It transpired that it was almost the same spot, near an immense kitchenmidden composed of cockle shells, where the late Captain Carrington so narrowly escaped being speared, the weapon passing between his arm and body. We could find no sign of the bodies, they having evidently been thrown into the river, which was simply alive with alligators. The cutter we found secreted in the mangroves, with all the spars and gear cut out of her. Several holes had been made in her top sides and in her lockers, evidently with a tomahawk, while she also had a mangrove stump through her bottom. On a sandy beach, well back from the mangroves, we found blood-stained 


\section{IN AUSTRALIAN TROPICS}

clothing and boat's gear. After an unsuccessful search for the bodies we steamed up the river to the original camp, where we found everything intact. What a haul it would have been for the blacks if they had realised that it had been abandoned, for there were axes, saws, and other tools and rations lying about in the open tents. We soon had everything on board.

When returning down the river, within four or five miles of the anchorage, we noticed some niggers on the beach, who were making signs for us to land, which we did. Their conduct looked very suspicious, and, as it was a splendid place for an ambush, we speedily offered an argument which made the blacks beat a retreat. 'Larrikin,' who was with us, recognised the murderers in the party. We searched their camp, destroying or carrying away all their valuables, such as dilly bags, bones of defunct relatives, spears, etc. We also found some Malay clothing, and several articles belonging to the cutter. A fine Malay canoe, which had for a painter a blood-stained piece of rope from the cutter, was confiscated. Among the articles brought away were some native mosquito nets, made of finely plaited grass, evidently worn over the head while asleep. These were eloquent testimony to the number and activity of the mosquitoes which infested these shores! I annexed a magnificent barromundi, which gave us a splendid fish dinner that evening. Mr. Uhr having in the meantime got the cutter afloat, we were soon on board, and a start was made for home. So closed that incident.

The nigrerers on this part of the coast had a particularly 



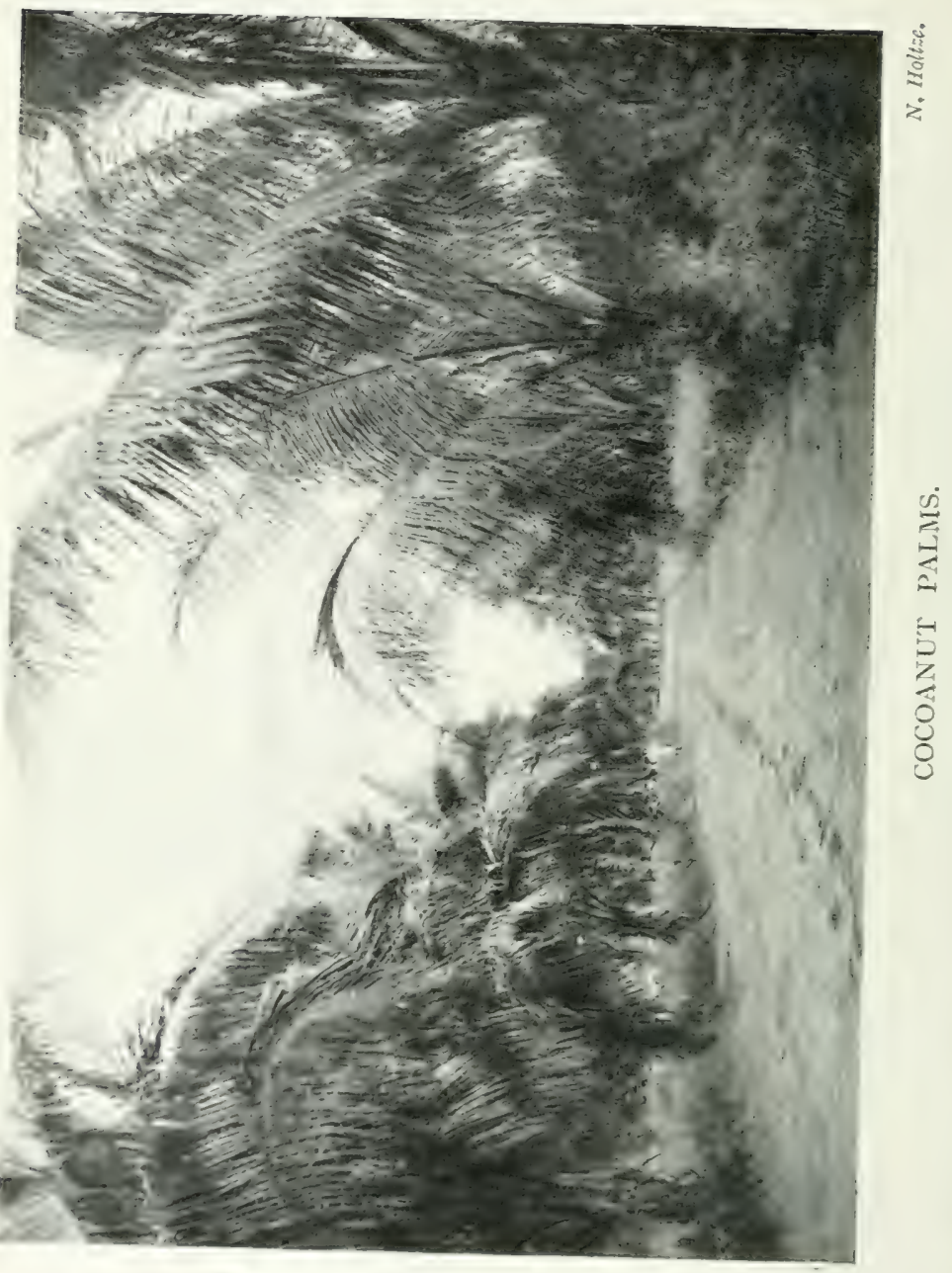




\section{FLORIDA HEAD STATION}

bad name. At the station, Florida by name, about twenty miles up the river, the aborigines were never allowed on the same side of the river as the settlement. It was a case of shooting at sight if they did venture across. Mr. Uhr, who had been exploring during our absence, had been very successful in his quest for Cypress Pine, but owing to the action of the niggers his party would not stop, so the cutting was abandoned.

Just read this description of Florida Head station written in 1888 by Mr. D'Arcy Uhr:-

'The homestead of Florida Head station is situated on a bold ridge, the foot of which is encircled by a horseshoe lagoon, forming one of the most beautiful sites for a station that I have ever seen. The ends of the lagoon are connected by a substantial fence, thus enclosing a splendid paddock of about one hundred and twenty acres. At the foot of the slope, below the station, and bordering the lagoon, a small garden had been formed, which, although only two years old, is a surprise in itself, for the growth of the various plants and trees has been simply marvellous. There are mulberry, orange, lemon, mango, pawpaw, and several kind of fruit trees, cocoa-nut palms, bananas, pineapples, and numerous other fruits and vegetables. The soil is a black friable loam equal to anything I have seen in Australia. I know the best country in Queensland pretty well, and I confidently state that $I$ have seen nothing there to beat it. A crop of maize that I inspected, although only sown seven weeks before, was then over seven feet high, and the cobs gave promise of a most prolific crop. The plains around the station are covered with wild rice, and the Chinese gardener asserts that the rice will do better here than in China or Saigon. The rainfall is pretty regular all the year through, and since the station has been formed there has never been more than two months without rain. The station paddock, although only about one 


\section{IN AUSTRALIAN TROPICS}

hundred and twenty acres in extent, has carricd a large quantity of stock, but the grass has never been known to be scarce in it. The country all around the station is alive with game and wild fowl, while the lagoon teems with a number of varieties of fish. Wild fowls' eggs may be obtained by the bucketful. About five miles S.S.W. of the station, Lindsay's Mount Delight is a prominent object in the landscape. This ought to be magnificent sugar country, and is well worthy the attention of sugar-planters. Mosquitoes are the bane of one's existence here, keeping up their activity night and day, but the small "buffaloo," or marsh "fly," so numerous in other parts of the Territory, is not known here, which must be a great boon to horses and cattle. White ants are almost unknown, those hitherto seen being the smaller and less troublesome sort, which build their hills of black soil. The cattle I have seen look remarkably well and healthy. This portion of the country was surely never intended by Dame Nature to belong to the Northern Territory. It ought to be joined on to Queensland-in fact, the soil is quite equal to anything in the Maryborough or Mackity districts, which are admittedly the pick of Queensland.'

That is an examp.c of the fertility of the country.

When clear of the river we ran into very heavy weather, so the old man brought up in what he supposed to be an anchorage under a reef. It may have been, but the steamer rolled and plunged as if the wanted to get rid of her engrines. On account of the sea and spray, and heavy rain, it was almost impossible to stay on leck. In conscquence nine men were cooped up in the little cabin close to the boiler. What with the smell of the bilge-water, heat from the boilcrs, and confined air, we harl a bad time of it. Jlaving a top bunk, every now and then when my side was on top I would open the 


\section{A FINE ANCHORAGE}

port-hole, and so get a breath of fresh air. Just to give an idea of the atmosphere in our palatial cabin. Every day the brass-work was polished, but it was a work of supererogation, for in half an hour it was as black as could be from the fumes of the bilge-water. One of the passengers, a proper bushman and a real good fellow, who, I believe, had not seen the sea until he joined the steamer at the MI'Arthur, was in a lively state. During the throes of enjoying himself he yelled to the skipper, 'O captain, can't you hobble her out?' Next day we manasred to get away from this very fine anchorage, and proceeded on our voyage, calling at Bowen Straits for the Malay money. We arrived at Port Darwin without further incident. 


\section{CHAPTER IX}

\section{TO THE WEST IN SEARCH OF MALAY PROAS}

IT being rumoured that some of the Macassar proas, with the intention of evading the Customs, purposed fishing on the coast to the west of Port Darwin, I, in I889, prosecuted a search to the boundary of Western Australia. In comparison with my previous trips, the one on this occasion was perfect luxury. We (for I was accompanied by two friends named Whitelaw and Mann) had a nice little steamer of so tons named the Adelaide. Having been built for tropical coast trade, she had her cabin on deck. We had a good cook, good tucker, and a good supply of those little trimmings which assist to malie life worth living. We coasted down to the Peron Islands at the mouth of the Daly River without discovering anything. We anchored there. Sharks were plentiful, and displayed great curiosity. By means of line and rifle we managed to despatch twelve. Some were real monsters.

In the morning, seeing a number of blacks on the beach to the west of the river, we went ashore. The only idea the aborigines seemed to have of Malay proas was that they were something good to eat. Having rewarded 


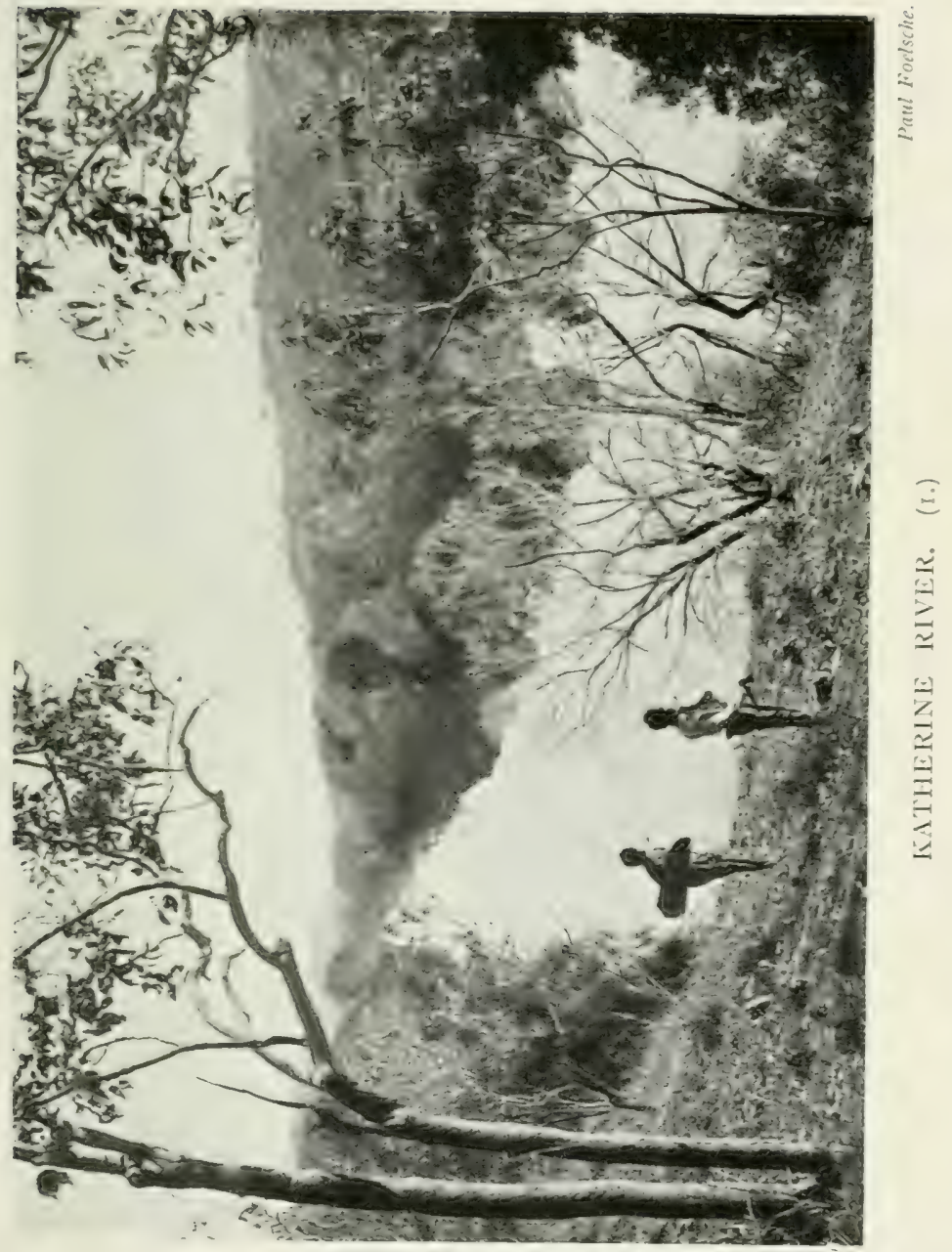



the niggers with tobacco and pipes we started for the steamer. It had come on to blow hard right in on to the shore, and a nasty sea was soon running. We had nearly three miles slogging before us. The boat was heavy, broad, and flat. If anything is calculated to knock the stiffening out of a man, it is pulling a boat of that description against a head sea. It had to be done, and was done. Once on board, a 'corpse reviver' was the first thing we demanded. A 'reviver' for one man consisted of an egg, a squeeze of lemon, a little sugar, a dash of Angostura, worked up with a swizzle-stick. To this was added a wine-glass of square gin or whisky. Once outside that concoction our hard pull seemed child'splay.

We next steamed to Cape Ford, and seeing a number of niggers ashore, we proceeded to interview them. Perhaps mistaking us for newspaper reporters, and not wanting the trouble of objecting to be questioned, they disappeared into the jungle, and remained there. At the niggers' camp we left our cards in the shape of pipes and tobacco. We rambled several miles along the coast, but found not a sign of any recent visit by the Malays. In the jungle, however, were undoubted evidences of their presence long, long ago. I mean the Tamarind trees. Some were fifty or sixty feet high, and evidently of great age. Of course we kept our weather eye lifted, for we were now in the country of the most bold, fearless, and ferocious niggers that could be found on the coast of Australia. No doubt they were handy somewhere about, watching for an opportunity to have a little excitement. 
As we ran along the coast signal fires sprang up just ahead of us, so the chaps at Port Keats were fully aware of our approach. I went up the port many miles in the boat and landed at several places. As usual, thinking we might reccive an official welcome from the niggers, we were prepared to return the compliment. There were no signs of proas, except numbers of great Tamarind trees. I believe we were the first white men to enter Port Keats since Captain King discovered it in I819. Port Keats is now (1906) the scene of boring operations for coal, on the recommendation of Mr. H. Y. L. Brown, the Government Geologist for South Australia. As far as they have gone the indications are most favourable. I do not give this piece of information with a view of advertising Port Keats, but to bring in a few particulars of a terrible massacre which has lately taken place a short distance away from that port.

Just before last Christmas Mr. F. Bradshaw, a Victoria River squatter, was proceeding to Port Darwin in his oil launch, accompanied by two friends and an engineer, a Russian Finn. He called in at Port Keats, where the Victoria River boys he had with him deserted. IIe had persuaded five of the Port Keats niggers to join the launch, said good-bye, and that was the last time those four white men were secn alive. From what transpired afterwards it seems that when some forty miles on the way, the launch was anchored close in to the shore, and the white men went to sleep. During the night some of the Myalls must have swum off, and with the assistance 
of the niggers on board killed the four men with waddies. The bodies were afterwards found on the beach in a terrible state. The launch was looted.

Mr. Bradshaw was well known for the kindness with which he had always treated the blacks on his station, and the great trust he had always placed in them. It had been predicted that his kindness would some day be repaid by treachery. There is no evidence that the unfortunate man's own boys from the Victoria River who deserted at Port Keats were concerned in the tragedy, but I should not be surprised if such were the case. The nigger, even the half-civilised one, is an uncertain animal, and always possesses the brute desire to kill.

The Russian encrincer, named Ivan Egeroffe, some five years previously had a miraculous escape. He was up the Daly with a mate in a launch, when the party was attacked. Egeroffe's mate was killed, but he was knocked overboard, and so managed to get away from the murderers.

About the same time as the massacre, but during the day, the camp at Port Keats was attacked, but the niggers were repulsed before any damage was done. The first report, received at Darwin through a nigger source, was to the effect that some of the men were killed. This is easily explained, for if a nigger is struck, he immediately asks, 'What for you killem me along a head ?' or other portion of the body on which he is struck. The fact of striking is killing with him. Two of the boring party were certainly struck, and had it not been 


\section{IN AUSTRALIAN TROPICS}

for the promptness with which the firearms were brought into use, things would have been serious. When the boring party first went to Port Keats, a great number of niggers were there, and they assisted in getting the machinery and camp equipment ashore. When the camp was formed they were allowed to knock about in it. Now, this was a great mistake, and should never have been permitted. The party soon found out that it was bad policy, for the niggers became very insolent, and did a considerable amount of stealing. It was also noticed that the women had disappeared. That ought to have been sign enough to anybody who knew anything about niggers that diplomatic relations were off. These instances further illustrate what has to be undertaken by those engaged in developing the resources of the outposts of the Empire.

The blacks at Port Keats, if they did not come from the Fitzmaurice River, were evidently of the same breed. Their features bear a remarkably Eastern, almost Jewish cast. They are inclined to be copper-coloured, with rather an aquiline nose. The hair, instead of being woolly, is long and straight. Both men and women have a very fine physique. Generally the men are six feet in height. I have never seen, or even heard of, natives of a similar type being found on the north coast. There is a foreign strain in those people somewhere. It may have come from the Malays, who undoubtedly visited that portion of the coast many, many years ago. They probably came down centuries ago. The reason for such an assumption I will show later on. Dr. A. F. Lynch, whowas 



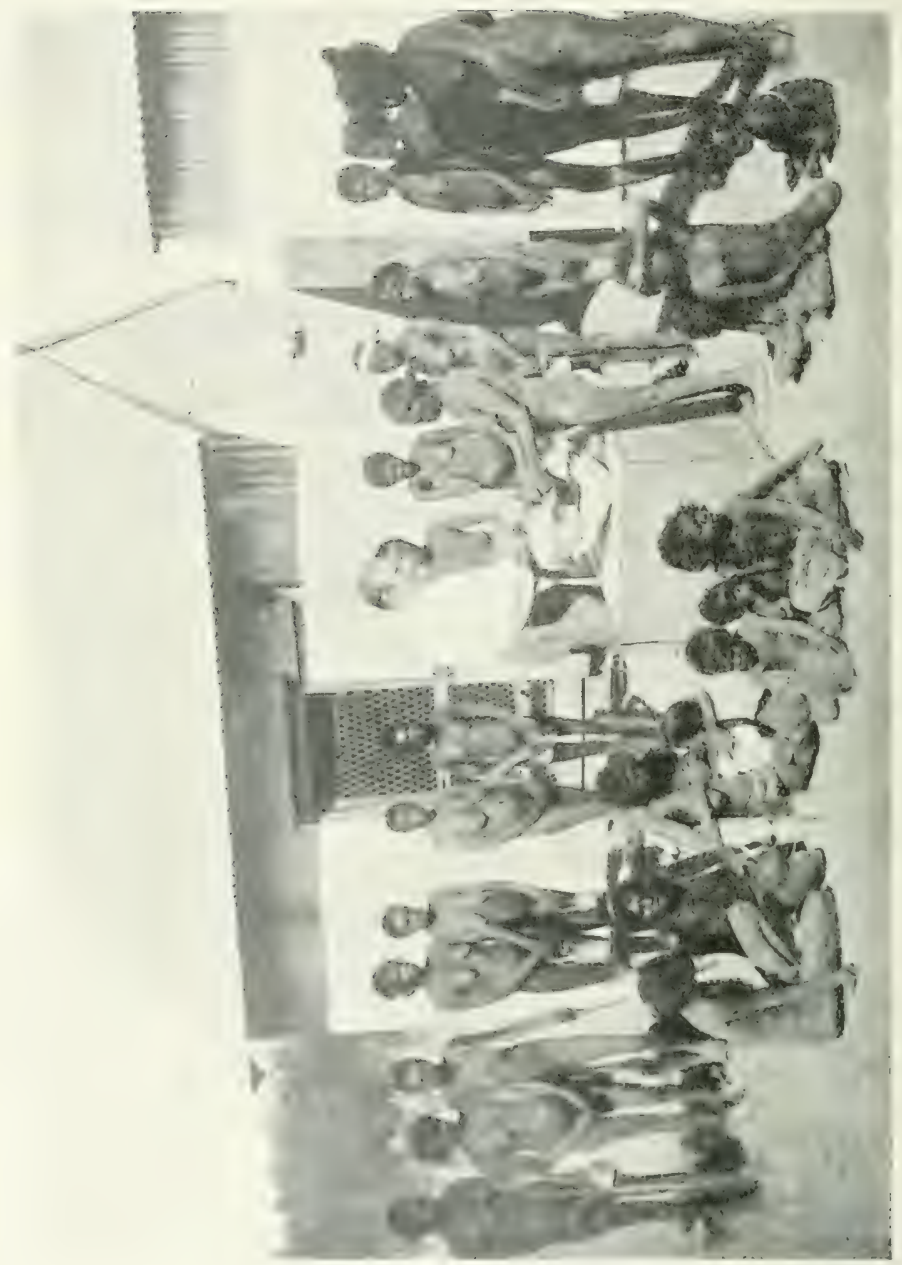

$\vdots$
$\vdots$
$\vdots$

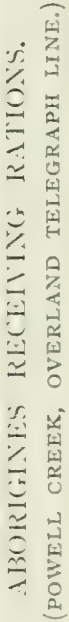


the Government up-country medical man for some ycars, and who had to visit the Daly River on many occasions, saw some of the Fitzmaurice tribes, who at times went visiting the neighbouring tribes. The doctor's description of the natives agrees with what I have written. In speaking about them, he said: 'Nearly every Fitzmaurice lubra has four or five children at her feet. You have to go to that country to realise what it means to the blacks not to be contaminated by civilisation. On one trip, when I went out to the Daly I saw several huncired niggers in big tribes, and I discovered several cases of leprosy. I don't think there is any doubt about the Fitzmaurice niggers being cannibals. I secured a couple of dilly-bags, and in one I found the remains of a human hand, that of a child, which had been cooked. It had been dropped into the coals. I thought at first it was wild pig, but a medical man spots the human hand pretty quickly. On the same occasion I obtained a glass spear-head, made out of a lemonade bottle. It was in the shape of a leaf, and was as artistically and beautifully made as if it had been ground by an emery wheel. The niggers regard the glass spears as special little gifts for the white man. It is far and away the most dangerous spear-head. It is much easier to extricate a wooden barbed spear than a glass one. Directly the latter penetrates the flesh it breaks off from the long bamboo to which it is attached, and the swelling covers it up, and renders it exceedingly difficult to remove. These spears are often dipped into the poison of decayed human flesh.' 


\section{IN AUSTRALIAN TROPICS}

From Fort Keats we coasted to Treachery Bay, where we anchored. The bay was so called from the fact that Captain Stokes of the Beagle was speared here. The story is graphically told by Captain Stokes in The Voyage of H.M.S. Bergle, in the following words :-

'I had just turned my head round to look after my followers when I was suddenly staggered by a violent and piercing blow about the left shoulder, and ere the dart had ceased to quiver in its destined mark, a long, loud yell, such as the savage only can produce, told me by whom I had been speared. One glance sufficed to show me the cliffs-so lately the abode of silence and solitude-swarming with the dusky forms of the natives, now indulging in all the exuberant action with which the Australian testifies his delight. One tall, bushy-headed fellow led the group, and was evidently my successful assailant. I drew out the spear, which had entered the cavity of the chest, and retreated with all the swiftness I could command, in the hope of reaching those who were coming up from the boat, and were then about half-way. I fully expected another spear while my back was turned; but, fortunately, the savages seemed only to think of getting down to the beach to complete their work. Onward I hurried, carrying the spear which I had drawn from the wound, and determined if, as I expected, overtaken, to sell my life dearly. Each step, less steady than the former one, reminded me that I was fast losing blood; but I hurried on, still retaining the chronometer and grasping my only waipon of defence. The sarage cry soon told me that my pursucrs had found their way to the beach, while at every respiration the air escaping through the orifice of the wound warned me that the strength hy which I was still enalifed to struighle through the deep pools and various: impediments in my path must fail me soon. I had fallen twice, each d: 
the bloodhounds behind. To add to my distress, I now saw with utter dismay that Mr. Tarrant and the man with the instruments, unconscious of the fact that I had been speared, and therefore believing that I could make good my escape, were moving off towards the boat. I gave up all hope, and with that rapid glance at the past which in such an hour crowds the whole history of life upon the mind, and one brief mental act of supplication, or rather submission to Him in whose hands are the issues of life and death, I prepared for the last dread struggle. At that moment the attention of the retreating party was aroused by a boat approaching hastily from the ship-the first long, loud, wild shriek of the natives having most providentially apprised those on board of our danger. They turned, and perceived that I was completely exhausted. I spent the last struggling energy I possessed to join them. Supported on each side I had just strength to direct them to turn towards our savage enemies, who were hurrying on in a long file, shouting and waving their clubs, and were now only about thirty yards off. Our turning momentarily checked their advance, whilst their force increased. During these very few and awfully anxious moments a party, headed by Lieutenant Emery, hastened over the reef to our support. Another moment and ours would have been the fate of so many other explorers; the hand of the savage almost grasped our throats. We should have fallen a sacrifice in the cause of discovery, and our bones, left to moulder on this distant shore, would have been trodden heedlessly underfoot by the wandering native. At the sight of Lieutenant Emery's party the natives flew with the utmost rapidity, covering their flight, either from chance or skill, by my party. In a moment the air, so lately echoing with their ferocious yells, was silent, and the scene of their intended massacre as lonely and deserted as before. I was soon got down to the boat, lifted over the ship's side, and stretched on the poop calin table under the care of Mr. Bynoe, who on probing the wound gave me a cheering hope of its not proving fatal. The 


\section{IN AUSTRALIAN TROPICS}

anxiety with which I watched his countenance, and listened to the words of life or death, the reader may imagine, but I cannot attempt to describe. The natives never throw a spear when the eye of the person they aim at is turned towards them, supposing that every one like themselves can avoid it. This was fortunate, as, my side being towards them, the spear had to pass through the thick muscles of the breast before reaching my lungs. Another circumstance in my favour was that I had been very much reduced by late exertions. The sufferings of that night I will not fatigue my readers by describing; but I can ne:er forget the anxiety with which Mr. Bynoe watched over me during the whole of it. Neither can I forget my feelings of gratitude to the Almighty when my sunken eyes the next morning once more caught the first rays of the sun. It seemed as though I could discover in those an assurance that my hour was not yet come, and that it would be my lot for some time longer to gaze with grateful pleasure on their splendour. Several excursions were made during my stay in search of the natives, but without success. An encampment was found in the neighbourhood near a small fresh-water swamp, and by the things that were left behind it was evident that a hasty retreat had been made. It would have been as well if we could have punished these people in some way for their unprovoked attack, but to have followed them far into the bush would have been quite useless. A comparison of their conduct with that of the natives of Shoal Bay confirms what I have before stated of the extraordinary contrasts presented by the dispositions of the aboriginal inhahitants in Australia, for in both instances we were the first Europeans they had ever encountered. The observations, which nearly cost me my life in endeavouring to obtain, placed Point Pearce in lat. $14^{\circ} 25 \mathrm{~m} .50 \mathrm{~s}$. S.; lons. $2^{\circ} 49 \mathrm{~m}$. W. of Port Essington. The time of high water at the full and change was seven o'clock, when the tides rose from twenty to twenty-six feet. The cliffs forming it are of a reddish hue, from the puantity of iron the rocks in the neighhourhood contain. To conmemorate the 
accident which befell me, the bay within Point Pearce was called 'Treachery liay, and a high hill over it, Providence Hill.'

When landins, we had to pull through about a quarter of a mile of clumps of young mangroves, which showed some three fect above the water. There was not a ripple at the time, the water being like liquid glass, but there was a long and heavy range. The graceful bowing of the green mangroves caused by the range was very beautiful indeed, and would have made a lovely picture. As we went inland-I, as usual, being a bit of an 'old hatter,' going by myself - we did not see any signs of niggers, but all at once one of the party sang out, 'Look out, Searcy, the niggers are around us!' We retreated immediately, and saw fresh nigger tracks over ours. The aborigines did not show up until we were a few yards away from the beach, when several rushed down, shaking their spears and making most unbecoming signs to us. They retreated as we returned to the beach, and came down again when we left. I do not think they quite understood firearms, or they would never have ventured so close in the way they did. It was fortunate for them that they did not let a single spear go. I am certain of one thing, if the niggers had shown up to my mates and myself when we were out of sight of the boat, and had behaved in a similar manner, they would have had a bad time. It was not wise to have too many witnesses when inflicting summary punishment. The coxswain of my boat was a man not to be trusted.

After dinner that evening, being at anchor, we sat 


\section{IN AUSTRALIAN TROPICS}

down to a game of 'nap' in the cabin which was on deck. I remember the state of the game well, a fine big 'kitty' and a treble header at that. We were all very intent on the game when crash, bang, rattle, bang, crash! a most infernal din right alongside of us. Out we rushed as if a certain old gentleman were at our heels. The skipper yelled out, 'What the something is that?' The Chinese cook, in a very mild voice, explained, 'All li, captain, only chin, chin, Joss.' 'Chin, chin, something,' yelled the skipper, 'do you want to frighten the something life out of us?' The wretched Celestial had put a lighted packet of crackers into an empty kerosene tin. You try it; you will be surprised at the noise it makes. That is how they try to frighten those pests the sparrows and the starlings from the gardens and vineyards in South Australia.

From Treachery Bay we steamed to Fossil Head, so named from the numerous and extraordinary fossils found there. Here were some enormous baobab-trees; in fact, they were the largest I saw on the coast. At the back of the Head there appeared to be permanent water. All along the coast, from Point Pearce right up to the Mosquito Flats in the Victoria River, baobab-trees are to be found. We steamed into the Fitzmaurice River, but did not ascend far, as it is only navigable for small vessels, and that for a distance of thirty miles. Since I was there the Government Geologist visited the country, and at the mouth of the river discovered auriferous rocks. This vast portion of our Territory has never been explored for gold or other minerals, so the possibilities 


\section{ABSENCE OF MALAYS}

are simply immense. IIaving steamed on till we touched the Westralian border without secing anything indicating recent visits of Malays, we turned round and made for home.

I will give my reasons for assuming that the Malays had not been on the coast for a very long period. In the first instance, there is little or no protection from the trade-winds, and proas must have shelter. And, again, the fishing could not be carried on in the rough water that would generally prevail during the nor'-westers. Another reason is the ferocity of the niggers. No doubt if we could look back into the dim past we would learn that some terrible tragedies were enacted in these parts. A few trials and tribulations would satisfy the Malays that they had not struck an ideal place to carry on their work of trepanging. Then, again, there are the terrific tides, which increase in strength the further you go to the westward. After rounding Cape Pearce I noticed the water was like pea-soup. In fact, during the many times I was in those waters I never saw the sea different. I never heard of the niggers to the westward of Port Darwin using the Malay language. 


\section{CHAPTER X}

\section{A TRIP TO THE VICTORIA RIVER}

IT was in ISS9 that I made my first trip to the Victoria River, situated close on our western boundary. We had a splendid run to the river, the only bit of excitement being in negotiating a sort of rip and tide race combined when round Point Pearce. The launch got through after giving herself and us a proper ducking. When the sun had had fair-play for a few minutes we were white, so was the launch, from truck to deck.

' This indeed is a noble river, and is worthy of being honoured with the name of Her Gracious Majesty.' Such were the words used by Captain Stokes one October evening some sixty-seven years ago, when he and his boat's crew in H.M.S. Beagle's launch, shot between Indian Hill and Pine leak, the rugged sentinels that guard the inner entrance to the river. It was to be the Murray of the north.

In his eager enthusiasm Captain Stokes wrote: 'I would fain hope that ere the sand of my life-glass has run out, other feet than mine will have trod this distant shore; that colonisation will, ere many years have passed, have extended itself into this (fuirter, that 


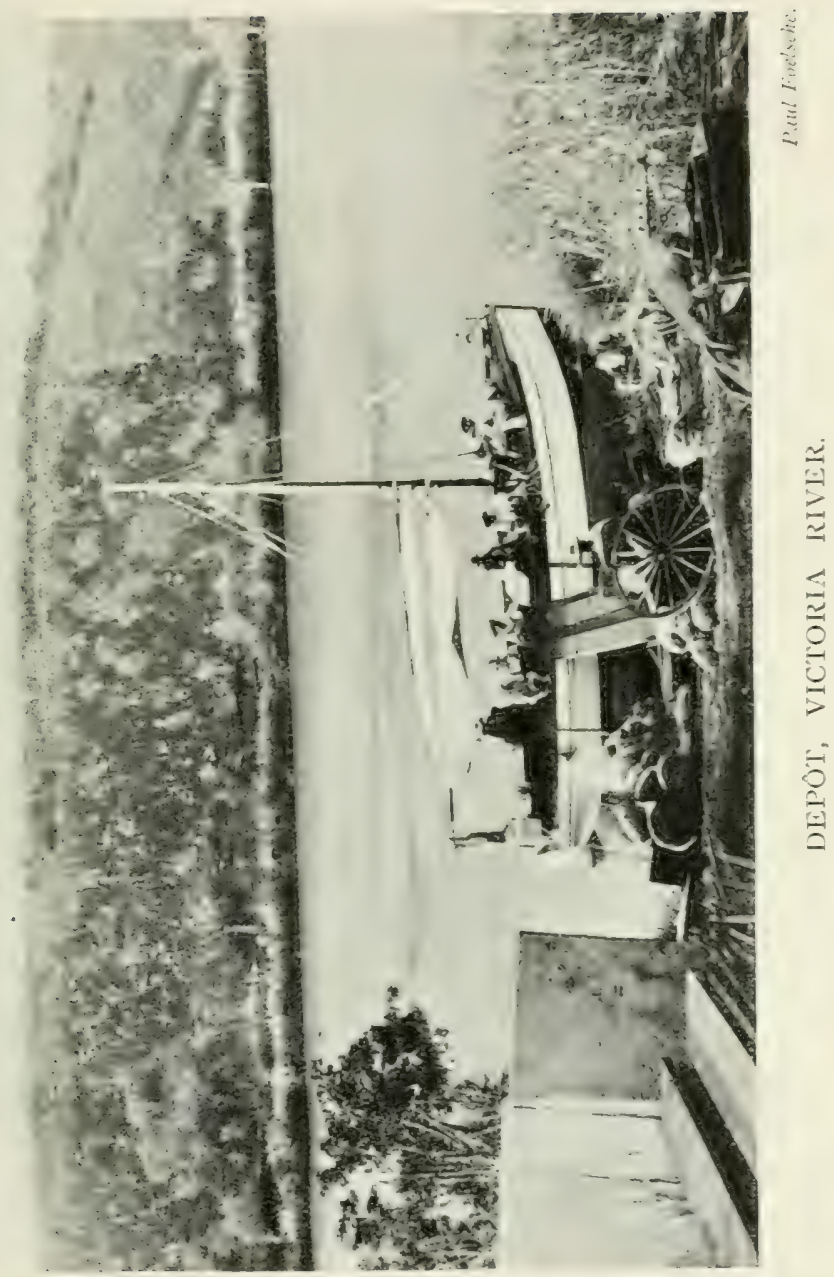



cities and hamlets will have arisen on the shore of the new-found river, that commerce will have directed her track thither, and that smoke may arise from Christian hearths, where now alone the prowling heathen lights his fire.'

Unfortunately the dream has not been realised, for beyond the formation of a few immense stations carrying tens of thousands of cattle, nothing has been done. The possibilities are immense. As a cattle-raising country it is unsurpassed in the world. Besides, it is confidently felt that in the vicinity there are great deposits of minerals and coal.

In the steamer we ran up to Holdfast Reach, a distance of fifty miles. Holdfast Reach received this name owing to the fact that the Beagle lost two anchors here. They sank so deep into the quicksand that it was impossible to heave them out. The quicksands are so treacherous that it is necessary to lift the anchors every second day. At the Reach was an ancient baobab-tree, close to the water's edge, upon which the word 'Beagle' had been carved, but only the letters BEA were visible, and above them some Vandal had recently carved a large $\mathrm{G}$.

The Victoria is navigable for vessels of the largest class for a distance of fifty miles from the sea, and further for a distance of sixty miles for a suitable river craft drawing not more than three feet. For a distance of forty miles above the Reach the river is more or less filled with extensive quicksands. In some places there are deep channels through the quicksands, and in other instances the sands form flat bars right across the river, 


\section{IN AUSTRALIAN TROPICS}

which carry only a few feet at high water. These shoals and bars are subject to great and frequent changes, changes so great that it is difficult to realise them.

We continued our voyage in a lighter called the $A r k$, which, when in ballast, would almost float on a heavy dew, but now being full of stores she drew just under three feet. The river's course from the Reach to the terrible and much-dreaded Mosquito Flats, forty miles further on, where treachercus quicksand banks and unmerciful tides abound, was through bold, frowning sandstone ranges, relieved here and there by wonderful growths of hardy short bushes or trees, principally baobabs.

Beyond the scowling, sunburnt, sombre passes could be seen bright green valleys. The Rev. J. E. Tenison Wood described this portion of the river as being the most weird-looking country he had ever seen in Australia. As can be imagined, the extraordinary formation of the ranges and ravines is conducive to echoes. I fired away many cartridges, and the effect of the booming sound travelling from range to range, from ravine to ravine, and from one side of the river to the other, was magnificent. Before reaching the Flats we smelt the bottom several times. Once there, however, we were soon hard and fast. Then followed a hard fight, which lasted three days, before we were across the five miles of treacherous sands. The heat was intense, and there was hardly a breath of air. The incessant hauling, kedging, into the channel, then out of the channel with the rushing, swirling tide, sometimes coming up like a wall quite two fect 


\section{MOSQUITO FLATS}

high, was simply heart-breaking. But perseverance and 'Real Old Mackay' took us into deep water beyond the Flats. The facility with which the channel through the Flats changes its contour or disappears altogether is magical. A channel which may be eight feet deep at one set of spring-tides, may be a huge sandbank, almost dry at high-water, during the next tides.

Once a small schooner had gone hard and dry on a bank on the Flats, and to lighten her, her cargo was conveyed in boats to an island upon which mangroves were growing. Floating into decp water the boats were sent back for the cargo, but neither island nor cargo could be discovered. During the day, in the trees on the bank nearest to us, were thousands and thousands of white cockatoos. They kept up a screaming as if possessed of ten thousand devils. The noise was enough to drive us silly. The birds seemed to enjoy the difficulties we were in, and the screeching may have been their idea of laughter.

The river Bains empties itself into the Victoria at the Flats, and on each side are extraordinary formations, one known as Curiosity Peak and the other the Dome. The three features mentioned are never forgotten by those who have negotiated this portion of the river. For the next twenty miles to the depot we had no trouble except that the sweeps had to be used nearly all the distance. A number of out-back station people were in with their teams and pack-horses for their stores. These horses, although just off a hundred miles' stage, looked as fat and fresh as could be, which spoke volumes 


\section{IN AUSTRALIAN TROPICS}

for the Victoria Downs country. Fifty miles from the depot was a place called Jasper Creek Gorge, through which all those from out-beyond making for the depot had to pass. This is a favourite spot for the niggers to meet and interfere with the teams. The gorge is several miles in length, and from its peculiar formation the niggers, if they had any sense, would be masters of the situation, and could annihilate travellers by rolling rocks down the sides of the steep hills. Fortunately for travellers, the blacks have not grasped the strategical strength of the position. Not long after we were at the depot two teamsters, $\mathrm{M} \longrightarrow$ and $\mathrm{L} \longrightarrow$, when camped in the gorge, were attacked by the niggers and badly speared. M- received a stone spear in his thigh which wounded him seriously. L- was first speared in the back, the stone head entering his lungs, and immediately afterwards he stopped a glass-headed spear which nearly lifted the nose from his face. The glass head broke off and remained in the wound. I saw it there when he came to Darwin for medical treatment. M- managed to drag the spear out of his thigh. The men fired many shots, which had the effect of keeping the niggers at a distance during the night. In the morning the two unfortunates erected a barricade round the wargron with bags of flour and sugar. The exertion caused the spear-head in L_'s back to work out a bit, so M- managed to extract it. During the next two days the men kept the niggers at bay, although great numbers were around them, occasionally throwing spears. The besicered also had reason to know that 


\section{A DUEL}

their own boys had joined the Myall niggers, for an occasional shot was fired at them. After two days of suffering, there being no prospect of a rescue, the men made up their minds to endeavour to escape. This they did by creeping out and catching two draught horses. It seems almost inconceivable that these two men rode about eighty miles before they arrived at the Auvergne Station. They were nearly mad with pain, almost dead from loss of blood, yet they got through. This is an example of the sort of stuff our out-back men are made of. Both the men under medical treatment recovered, although L_'s face was rather disfigured. Poor old L_L had a failing, and that was lifting his little finger, and would at times become somewhat eccentric. He had served in the New Zealand war, where he received a bad wound in the head. I remember once one of his fingers offended him, so he shot the top of it off with his revolver. Once when he was on one of the out-beyond stations he and the manager had a dispute. They both had been indulging a bit too freely in the cup that does the other thing. It was decided that the dispute should be settled by a duel. So out they sallied with their rifles, and at a distance of about a hundred yards commenced to blaze away at each other. A considerable amount of ammunition was used without any damage being done, so they made friends and continued the same old drunk. When the scene of the fight at the gorge was visited, it was found that the niggers had speared many of the horses, likewise played havoc with the stores. 


\section{IN AUSTRALIAN TROPICS}

The ingenuity and patience exhibited by the Victoria River niggers in the manufacture of glass spear-heads from bottles is simply astounding. From a base of one to one and a half inches wide, they will chip the spear-head down until it has a point as fine as a needle. The stone spear-heads made by these blacks are nothing like as large as those used to the eastward.

On the way down the river we had a look at Gregory's old camp on the bank of the Victoria River. It had evidently been formed under two large baobab-trees. On the one nearest the bank several dates were cut. They evidently denoted the arrival of the party in I $\$ 55$, and were in a perfect state of preservation. On one of the trees was the message- 'Letter in forge,' and on the other, 'Letter in oven.' A quantity of pig-iron discharged from the schooner Tom Tough was used to build the forge and oven. Gregory's main camp was here for eight months. This grand old explorer, who was well over eighty years of age, died recently in Quecnsland. The baobob-tree is to be met with everywhere after rounding Point Pearce. Some of them grow to an enormous size. The largest specimens I saw were near Fossil IIead. The niggers prize the baobob-tree on account of the fruit, the seeds of which are eaten.

The Victoria River not having been explored since the time of Stokes, and being considered the largest river in Australia (except the Murray), no problem of greater interest could well be imagined than the possibility of the river entering the centre of Australia. Hence the fitting out of the exploring party under 


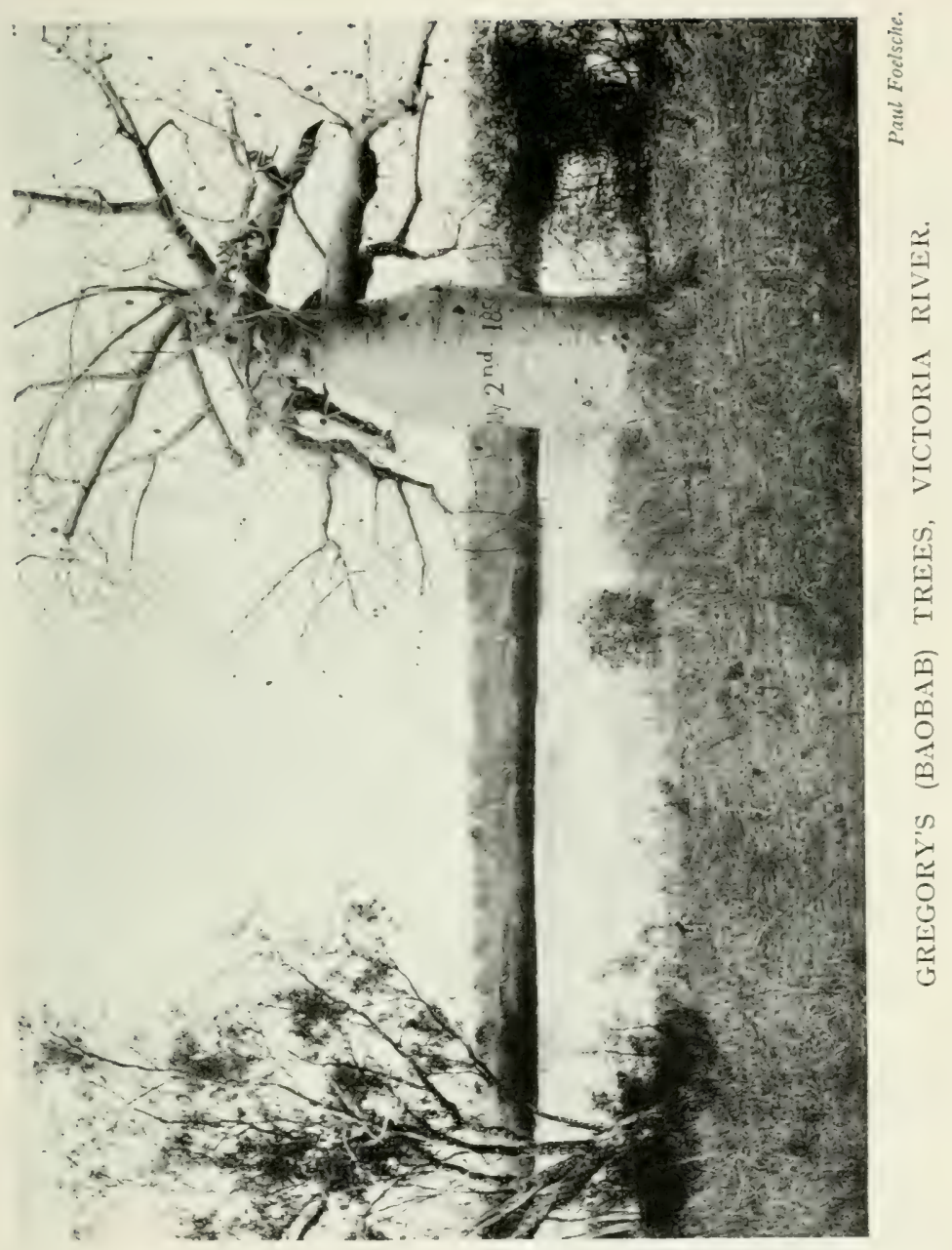





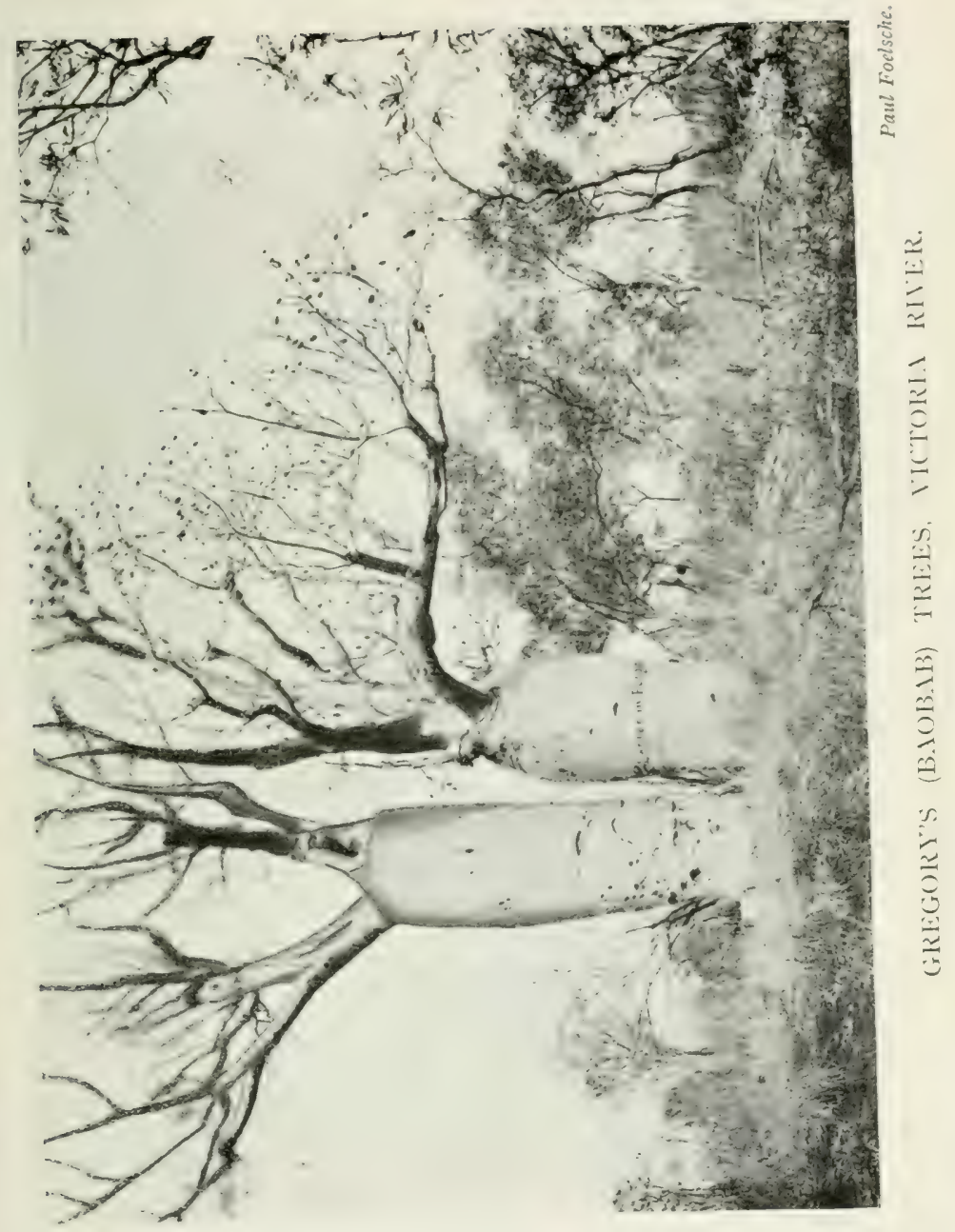



A. C. Gregory. The party, which included Dr. Mucller, the celebrated botanist, left Sydney on July 18, I 855 , and having called at Moreton Bay for a few of the party and live-stock, proceeded to Treachery Bay, near Point Pearce, not far from the mouth of the Victoria River. They went in the Monarch accompanied by the schooner Tom Tough. The latter vessel was to attend on the explorers on the river. The horses and several of the party were landed from the Monarch at Treachery Bay on September 24, and proceeded overland. The schooner worked her way up the river, and a main camp was formed at the boabab-trees. After encountering difficulties and hardships Gregory reached the head-waters of the river. Having accomplished his work the $\mathrm{cx}$ plorers started for home overland on June 2 I, I856, and reached Brisbane on November 16 , of the same year.

We paid a visit to Timber Creek, so named on account of the fact that timber used for repairing the Tom Tough was obtained there. The Tom Tough was a schooner of upwards of two hundred tons, and took stores up the river for Gregory. She was evidently of very shallow draft, and it must have been fearful work getting up the river. It, however, showed what grit and pluck can do. At any rate, the bottom was nearly knocked out of the schooner, and she had to undergo extensive repairs before she left the depot.

When passing through a belt of mangroves further down the river, we started thousands and thousands of flying-foxes. Soon a great eagle appeared on the scene, 
and having spotted a fine plump fox, started to cut it out. Away the victim went, dodging among its fellows. Every now and then we could hear a plaintive cry, as the eagle followed it up. The others did not seem to take the least notice. When the creature was fairly out of the crowd the eagle pounced on it and sailed away.

At the Mosquito Flats we had better luck, no doubt owing to the lighter not having any cargo, and we managed to get over in a day, although at times the tide was truly appalling. During our journcy down on one occasion, the tide rose twenty feet in two hours.

Near Curiosity Peak we sct fire to the country on the river-bank. There was no evidence of a single bird before, but at the first sign of smoke, hundreds and hundreds of bromli kites made their appearance, and watched for vermin. I suppose they must have been away aloft, but not visible to the eye.

During the dry season it is marvellous to sce the number of bromli kites everywhere. They are great scavengers, and have the cheek of a book-agent. They will swoop down and take the food off the plate in front of you. It is well worth watching the way they flash down and catch a piece of food thrown into the air. Where they come from is a mystery. The bromli kite is apparently the pariah or govind kite of India. The natives there call it the 'chill,' after the cry, which is a kind of long tremulous squeal-a most irritating noise it always seemed to me.

During our trip back to the Reach, it blew hard from 208 
the south-east, so we had it pretty near astern all the time. This sent us along merrily when the water was clear of obstructions. At night it was bitterly cold. It is astonishing how insinuating our winter (dry scason) winds, south-easters, are to be sure. They are dry, cold, and parching, and while they prevail, malarial fever is generally contracted, that is, by anybody who indulges in that luxury. How often we smokers blessed the south-easters, for it dried the tobacco so that the action of rubbing it up turned it into dust. In the wet season it is just the opposite; the trouble was to keep the tobacco dry. Many and many a time I had to dry mine over the lamp before I could get a decent smoke. The wet scason is very rough on matches. We nearly always used wax ones. What trouble we had to keep them at striking pitch. During the wet I always found blotting-paper the best to strike them on. Having to hold the match close to the head, it was no uncommon occurrence for a piece to lodge under your thumb when it ignited. In all my experience I never realised anything so calculated to cause extraordinary antics and language as a piece of wax vesta burning under your nail.

I wondered a bit we did not see any niggers when on the river, but many signal fires went up in the ranges.

A pleasant run home ended a most enjoyable trip.

Some time after this we started again for the Victoria River in the Victoria, and when off Cape Ford, a hundred miles from home, some mishap occurred to the boiler which promptly stopped our steaming. After about 


\section{IN AUSTRALIAN TROPICS}

three days' hard work the steamer was anchored safely under the Peron Islands. There was very little wind, so it meant towing her in a boat. Mr. Stevens, myself, a nigger, and a Chinaman started in the ship's boat for Darwin. IVe coasted all we could, working the tides where possible. The only time we had any wind was in crossing Fog Bay, when a very fierce squall came off the land with heavy rain, and slogging work it was to keep the boat in anything like a position. We reached Darwin just forty-five hours after leaving the steamer. That was not bad for four men in a heavy ship's boat. The heat was intense. 



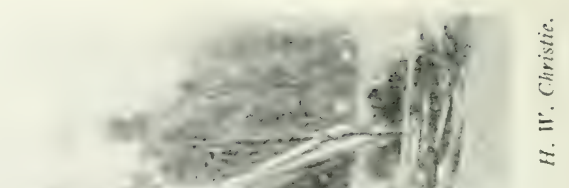

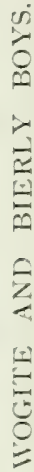




\section{CHAPTER XI}

THE CAPE BROGDEN MASSACRE

EARLY in the year 1892 the rumours of a terrible tragedy having taken place on the coast reached Port Darwin through the natives. The report was to the effect that a Malay proa had been wrecked and the crew killed by the niggers. I think it was in October of the same year that definite news was received in the shape of a report from Mr. E. O. Robinson to the Government Resident at the time, which confirmed the news that a massacre had taken place near Cape Brogden, some forty miles to the eastward of Robinson's Camp, at Bowen Straits, and that Wandy Wandy, who had already served a long term for the murder of Robinson's mate, was the ringleader.

A party under Inspector Foelsche was immediately fitted out to proceed to the spot to investigate. Inspector Foclsche's trump card in such matters was strategy, and it was felt that he would succeed in bringing matters to a successful issue. The Inspector during his long residence in the Northern Territory had made a perfect study of the natives, and had an intimate knowledge of their ways. In fact, among the niggers the name of Foelsche was a power in the land. When I saw the 


\section{IN AUSTRALIAN TROPICS}

other day that this valuable old servant had the I.S.M. conferred upon him I was delighted, and I am sure no man deserved it more. Always liking to see something fresh and to add to my experiences, I obtained permission to accompany the party. In the coasting steamer Adelaide we first proceeded to Port Essington to see if we could pick up any of the niggers who knew anything about the murder, but we drew a blank, for Port Essington was entirely deserted. The old camp and surrounding land, which Robinson in the old days kept so neat, were quite overgrown, and the place seemed to me to look miserable and desolate.

The steamer then proceeded to Bowen Straits Revenue Station, where Robinson had his camp. It was in charge of one of his men, a Malay, named Tingha de Hhans. Here Inspector Foelsche was successful in securing witnesses. With two policemen I crossed to Crocker Island to search for an important witness. In landing we had to make our way through a long stretch of heavy mud, and in doing so I gave my right knee a bad wrench, the source of an old trouble, the result of an accident while hunting. I had the satisfaction of walking some eight miles with a bent leg, but we secured the man. 'Flash Poll' was our guide. A move was then made to Cape Brogden, where we anchored, there being a nice ocean swell on. During the afternoon an effort was made to land, but on account of the heavy surf it was not safe to do so. At daybreak next morning, things being a bit quieter, we had another try. The boat's anchor was dropped well out, and the boat was eased in 
stern first until just outside the surf. We all got ashore safely with the assistance of niggers. I had one under each arm. You may be sure we looked after our shooting-irons.

One of the niggers, Mangerippy by name, led us inland about one and a half miles from the beach to a beautiful piece of jungle close to a pretty little lagoon, covered with lilies. It was hard to realise that such a peaceful and sylvan scene should have been the site of such bloody work, but we soon had evidences of the awful deed. Our guide pointed to several places in the jungle where the earth had been disturbed; here work was started, and we soon disclosed six skeletons. So as to have evidence of the six bodies, it was decided to take the skulls, which were considerably knocked about. The question of how to carry them-for they were not nice carrying-arose. I noticed that one of the niggers had on a pair of trousers. These were quickly unshipped and the ends of the legs tied up. We then put three skulls into each leg, and hung them round the nigger's neck, so the question of transport was soon settled. The rest of the bones were covered up again. While at work a buffalo cow and calf came to the lagoon for a drink, but having other business on hand we did not shoot. Close to where we landed were portions of the wrecked proa. The sea having gone down considerably, our return was made without difficulty.

Soon afterwards the two policemen and several diggers landed to search for the murderers. To my great disgust I could not accompany them on account of my knee. 


\section{IN AUSTRALIAN TROPICS}

After the search-party had landed we proceeded to Malay Bay, where it was arranged for the party to come out. Next evening the police were seen moving out of the bush. Upon landing I found they had four men in chains; among them was Wandy Wandy. As soon as he caught sight of me he cried out, ' $\mathrm{O}$ Mr. Searcy, I no' do it.' He and his mates were soon safely fixed up on the hatch of the steamer. The search-party had had a fairly exciting time, so I blessed my luck again. Next morning another man was secured. The names of the prisoners were Wandy Wandy, Capoondur, Ingeewaraky, Dooramite, Minaedge, and Angareeda.

The following is the story Mangerippy afterwards told: 'I live sometimes at Bowen Straits, sometimes in other parts of that district. I remember going with other black fellows, including all the prisoners, to Mandool and seeing Malays there, and a proa which had been broken. There were six Malays. At first the Malays spoke, but we did not understand, and they then said "Tingha," and pointed towards Bowen Straits. Black fellow say: "Take 'em," and then we started to show them the way to Bowen Straits. The prisoner Capoondur suggested that we should kill them, and another of the prisoners said the same. We took the Malays to a swamp, and stopped there to eat some cabbage-palm. Many of the black fellows carried up boxes from the beach. The Malays carried guns, but no boxes. They also carried revolver, bow and arrows, and knives. After dinner they walked again to Robinson's camp. Then two of the black fellows, who were carrying boxes, Mara- 
kite and Coolardno, ran away, taking the boxes with them. Then by and by all the black fellows carrying: boxes, including the prisoncrs, ran away, taking the boxes with them. I stopped a little while, and sang out to the blacks to come back, and then I ran away ton. I took the box I was carrying back to the old camp at the swamp. When I got back to the camp all the prisoners were there, also Arramboon. We sat down a little while, and then the Malays came back. When the Malays came back they sat down along with the black fellows. The blacks then talked among themselves about killing the Malays. All the prisoners said, "Kill 'em." I said, "You no' kill 'em." Arramboon also said, "No' kill 'em." Then the black fellows went into the bush and cut sticks, the Malays remaining sitting down at this camp. Minaedge was the first to talk about cutting sticks. They cut the sticks and then came back to the camp. Then Wandy Wandy took away the knife, bow and arrows, and revolver from the Malay captain, and Dooramite took two guns away from a Malay man. Then they ran away a little distance and stop there. Capoondur then hit the captain on the back of the head with a stick. The captain was sitting down, and died at once. Minaedge hit another Malay with a stick on the back of his head and killed him dead. Angareeda killed another same way. Coolardno killed another with a tomahawk, hitting him across the face. Marakite killed another with a stick. One Malay ran away, and Ingeewaraky threw a stick at him, but did not hit him. Coolardno then killed him. After they were all dead 


\section{IN AUSTRALIAN TROPICS}

Coolardno told me to go and spear all the dead men. and I did. Then Marakite told Arramboon to go and hit the dead men with a stick, and he did. After the Malays were killed we made holes and buried the bodies. We put three bodies in one hole, another body in a ho!e close by, another close to that, and another a little distance away. We then went away to the beach. We went and burnt the proa. All the prisoners were there, also Arramboon. The black fellows burnt the proa because they were afraid some white fellow might see it. It was Capoondur that talked that way. We then went back to the swamp, where we killed the Malays. We took the Malay's boxes, also arms and other things, and went to another swamp, where we slept for the night. It was in the afternoon that we burnt the proa. Next day we went to a fresh-water creek called Wark. I saw "Prince," "Larrikin," and "Big Jack" at Wark some time afterwards. All the prisoners were there, also lubras and children. I saw "Minaedge" give "Larrikin" a box. "Minaedge" said to "Larrikin" that he had killed a Malay and got the box. "Minaedge" told "Larrikin" not to tell anybody that he had killed a Malay. "Minaedge" then gave "Big Jack" a knife and saarong. I was close up when he gave it. He told "Big Jack" he killed the Malay, and took the knife and saarong from him.'

The wrecked proa-a small one-was not one of the regular visitors, but a stranger, as far as we could make out, from the Aru Islands, and had evidently been blown down. I expect the dialect the Malay used was some- 
what different from that to which our coast natives were accustomed, hence the difficulty they had in making themselves understood; but their mentioning 'Tingha' showed they had gained some knowledge of the camp at Bowen Straits. Wandy Wandy was afterwards executed at Malay Bay in the presence of as many of the natives as could be rounded up. The others received terms of imprisonment. Thus did Inspector Foelsche successfully carry out his work.

For many years there was no proper legally qualified judge presiding over the Criminal Court in Port Darwin, the Government Resident, who was a layman, acting in that capacity. Consequently capital offences could not be tried there. In several instances where murders had been committed by blacks, the men were on this account indicted for manslaughter. Wandy Wandy was a case in point, and he received a sentence of ten years' imprisonment. On Wandy Wandy's liberation he was taken in hand by the Jesuit Fathers, who had a mission station close to the town; but the outlaw's end proved how utterly futile their labours were. I knew the Fathers well. A finer lot of dear, earnest, hard-working men it would be impossible to find anywhere. All their endeavours, however, to civilise the blacks came to nought. The stations were given up after incalculable labours and the expenditure of an immense sum of money. The first Jucige sent to the Northern Territory was Judge Wearing. He and all his party were lost in the s.s. Gothenburg when that ill-fated ship was cast away in the Barrier in 1875 . There was an appalling loss of 


\section{IN AUSTRALIAN TROPICS}

life. This catastrophe and the great expense in sending a Judge and party to the Northern Territory was the cause of the arrangement I have mentioned. A resident Judge was appointed in 1884 . 


\section{CHAPTER XII}

EARLY MILITARY SETTLEMENTS-FORT DUNDAS

MENTION of the early military settlements on the north shore of Australia set me hunting up historical records dealing with their establishment. Several years ago, in some articles by the late Eneas J. Gunn on 'Pioneering in Northern Australia,' the writer said: 'In 1820 Captain King, in the ill-found So-ton cutter MIcrmaid, with no little heroism, boldly explored the coast, ventured where it seems almost a miracle he should have reached, and a still greater marvel that he should ever have escaped to recount his adventures. On his recommendation successive attempts at colonisation, under unpractical military rule, were made in $1 \$ 24$ at Fort Dundas and Raffles Bay, Melville Island, and subsequently some years later at Port Essington in Arnheim's Land. All in a few years languished, and were abandoned, owing to want of the requisite experience in their government, thereby casting a damning stigma on the Northern Territory, which is only now wearing off.' Melville Island was discovered in I 818 by Captain Philip P. King, who, in I818-I822, surveyed the north coast of Australia, and afterwards published $A$ Narrative of a Survey of the 


\section{IN AUSTRALIAN TROPICS}

Intertropical and Western Coasts of Australia, performed between ISIS and IS22. Curiously enough, the expedition missed Port Darwin, which was discovered by Captain Stokes, of the Beagle, in 1839, and named after his friend, the able naturalist, Charles Darwin.

It was not until some two years after the completion of Captain King's survey, that H.M.S. Tamar was despatched by the Admiralty for the purpose of choosing a suitable site on the northern coast of Australia for the establishment of a convict settlement. The Tamar arrived at Port Jackson on July 24, 1824, and in less than a month sailed thence on her mission, having on board a detachment of the 3rd Regiment, a party of the Royal Marines, and forty-five convicts. A landing was made at Port Essington; but after a vain search for permanent fresh water, the idea of settling at this place was abandoned. Lieutenant Roe, of the Tamar, in a letter to his former commander, Captain King, gives the following particulars concerning the founding of the settlement at Port Cockburn: 'Light winds retarded our arrival, and it was not before the 26th that we brought up close to Luxmore Head, in St. Asaph Bay. Possession was taken with the same forms as at Port Essington, and we commenced a strict search for water in every direction, but with no success. At the expiration of five or six days a small river and plenty of water were discovered in Melville Island, abreast of the Harris Islands, and an eligible situation for the intended new settlement being discovered near it, the ships were removed thither on Octuber 2, 1824, 



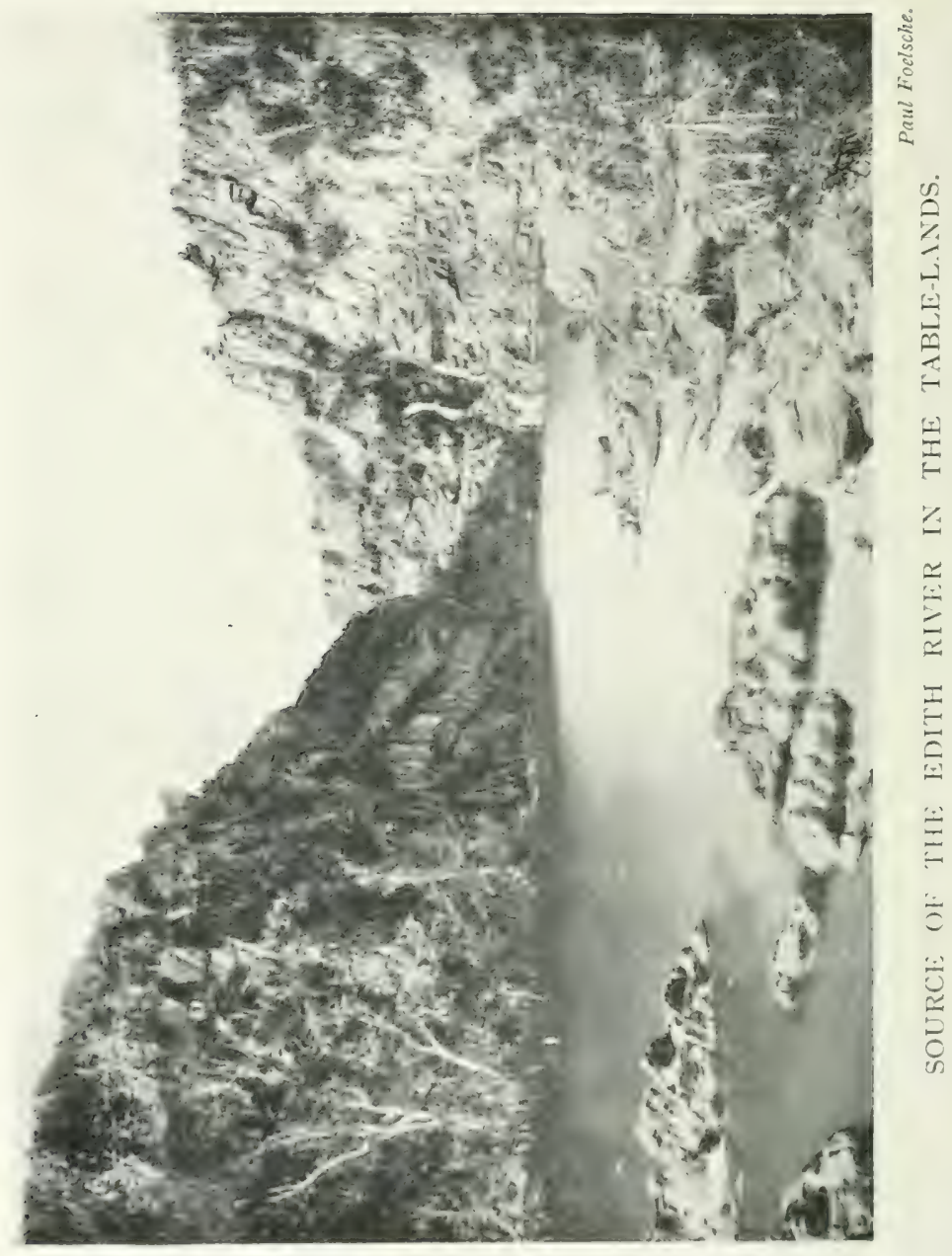




\section{FORT DUNDAS}

and parties landed to commence operations with axe and saw. The projection of land fixed upon for the site of a town was named after the Commandant (Captain Barlow); the cove was named King's Cove, after yourself, as the original discoverer of the strait; and that part of Apsley Strait, between Luxmore Ilead and Harris Island, received the name of Port Cockburn in honour of Vice-Admiral Sir George Cockburn, G.C.B. All disposable hands being employed in clearing the point, we were speedily enabled to commence the erection of a fort, seventy-five yards in length by fifty wide, to be built of the trunks of the felled trees, and to be surrounded by a ditch ten feet wide and deep. On the memorable October $2 \mathrm{I}$ our quarter-deck guns were landed and mounted, the colours were hoisted for the first time, and the work was named Fort Dundas under a royal salute from itself. Quarters were constructed within the walls of the fort for the accommodation of the officers, and about thirty huts of various kinds were erected and thatched with rushes for the soldiers and convicts. A deep well was sunk near the fort; a good substantial wharf ran out into the water, and as soon as a commissariat storehouse was finished, all the provisions were landed from the Countess of Harcourt and secured there. The soil in the neighbourhood of the settlement being exceedingly good, gardens were cleared and laid out, and soon produced all kinds of vegetables. In our stock we were rather unfortunate, for of six sheep that were landed for the purpose of breeding, five died-supposed from the effect produced 


\section{IN AUSTRALIAN TROPPICS}

by eating some pernicious herb in the woods. Pigs, ducks, and fowls seemed, however, in a fair way of doing well, and had increased considerably since they were landed; but great inconvenience was experienced for want of some horses or draught oxen, which would not only have materially expedited the work in hand, but spared the men much fatigue and exposure. But the work proceeded with such spirit and alacrity that we were enabled to sail for Bombay on November 13 without exposing the new settlement either to the jealousy of the Malays or the mischicvous attack of the natives. Not one native made his appearance before the early part of November, when, as if by a signal, a party of about eighteen on each shore communicated with us on the same day, and were very friendly, although exceedingly suspicious and timid. They would not venture within the line of the outer hut, and always came armed, but laid aside their spears and clubs whenever friendly signs were made. These Indians made repeated signs for hatchets, and although they had stolen two or three, it was considered desirable to gain their goodwill by giving them more. They were, of course, much pleased, but the next day axes, knives, and sickles were taken by force from men outside the settlement, upon which they were made to understand that until these articles were restored no more would be given. This course being persevered in by us, they seized these implements on every occasion that presented itsclf, so that it was found necessary to protect our working parties in the woods by a guard: the result 
of which was that the natives threw their sperirs whenever resistance was offered, and the guard was obliged to fire upon the aggressors. Open acts of hostility having now been committed, and the natives increasing daily in numbers to upwards of one hundred round the settlement, a good lookout was kept upon them, but not sufficiently to prevent about sixty of them surprising five of the marines in a swamp, cutting rushes, and throwing their spears among them. Their salute was immediately returned, and they disappeared without any damage having been done on either side. At the same minute, however, reports of musketry were heard at our watering-place and garden, and proved to be in repelling an attack that about forty natives had made upon our jolly-boat watering, and two men cutting grass. One of the natives was shot dead at ten yards' distance, while in the act of throwing his spear, and our people thought that several others were wounded, as they disappeared, making most strange noises, and have not been near us since. One of the spears thrown upon the last occasion had sixteen barbs to it, but, in general, they were merely scraped to a sharp point, without even one barb, and were not thrown with anything like precision or good aim.'

When the Tamar left, Lieutenant Roe considered the settlement to be in a very forward state, and ventured on a prophecy:-'Such is the state of the settlement of Fort Dundas, which at some future time must become a place of considerable consequence in the eastern world. The soil and climate of Melville and Bathurst Islands 


\section{IN AUSTRALIAN TROPICS}

are capable of growing all the valuable productions of the East, principally spices, and many other equally important articles of trade; it is conveniently placed for the protection of ships passing to our Indian possessions from Port Jackson, and admirably situated for the purposes of mercantile speculation.'

Fort Dundas was, however, doomed to failure. Towards the end of 1827 Major Campbell, who was appointed Commandant of Melville Island in August I 826, represented to the Governor of New South Wales the disadvantages under which the settlement laboured, among them the fact that at that time the island was out of the direct line of trade-no traders of any nation whatever had come near it. Port Darwin had not then been discovered. The main object of the Government in establishing the settlement-opening up commercial intercourse with the Indian Archipelago-had, he pointed out, been completely frustrated. Major Campbell's relations with the island ceased during 1827 , and we have to turn to another author-Mr. G. Windsor Earl, M.R.A.S., linguist of the North Australian Expedition and Commissioner of Crown Lands for Port Essington - for a few lines to complete the story of this unhappy garrison. In his work Enterprise in Tropical Australia, published in 1846 , he relates that Captain Stirling, H.M.S. Success, was despatched from Sydney in 1827 to found another settlement at Raffles Bay, on the mainland, thirteen miles east of Port Essington. He took three transports, conveying a detachment of troops, some convicts, stores, and implements. The garrison at 
Melville Island remained during two years subsequent to the occupation of Raffles Bay. The establishment was then (I \$29) broken up, and the stores removed to the latter settlement, which was also, according to Major Campbell, deserted in the same year, though Mr. Earle concludes: 'The settlement at Raffles Bay proved as prosperous as that at Melviile Island proved the reverse.' But all the authorities agree that Fort Dundas, Melville Island, was in I\$29 abandoned without regret by its garrison to the treacherous natives.

In July I 895 the niggers of Bathurst and Melville Islands must have been greatly astonished to see a fleet of five luggers sailing up Apsley Straits, for I do not suppose the Straits had been visited half a dozen times since the old days, when Fort Dundas was occupied. If the blacks did think, it must have been apparent to them that their long freedom from intrusion was now at an end. The pearlers knocking about the southern and eastern shores, the buffalo-shooters hard at work, and then to see the little known and almost unvisited Straits invaded must have made them conclude that they were not to have the islands to themselves any longer.

I was a passenger on one of the luggers.

The Straits are forty-five miles long, the widest portion being five miles, and the narrowest three-quarters of a mile. The flood-tide runs north to south, and the ebb south to north. At times it runs with terrible velocity, as we found one night when at anchor, for a hand had to be at the helm all tide-time. 


\section{IN AUSTRALIAN TROPICS}

Mangroves predominate on the margins of the islands, but there are small sandy beaches with belts of jungle and red cliffs at intervals.

The only mishap in running up the Straits happened to our lugger, for we smelt the bottom and stuck for four hours.

Our first anchorage was at Garden Point. Early in the morning we went on shore well armed. When halfway there we just missed a whirlpool, evidently a tidal one, which, if it had caught us, would have easily capsized the boat. De Rougemont, in his account of his marvellous adventures, mentions having narrowly escaped a whirlpool in Apsley Straits, which, according to his story, he passed through. However, he gave the show away when he spoke of the weapons the niggers used against him.

Our first landing was at Barlow Point, to have a look at Fort Dundas. Over slippery rocks we made our way through the mangroves up a rise, where we saw what at first appeared to be a watercourse. Upon following it round, however, we fulnd it was a real moat, with earthworks and bastions above it. So this was Fort Dundas, constructed so many years ago to resist the attacks of the natives, and, I suppose, the Malays. It seemed impossible to imagine that in those walls soldiers kept their weary watch-soldiers in their tightly buttoned red coats, and stiff leather stocks; for it was in the days of Brown Bess, stocks, martinets, and stiff shalios. If the niggers then went in for nirht-work, the moat must have afforded them excellent cover to crawl upon the unfortunate 


\section{FORT DUNDAS IN 1895}

sentrics, several of whom, it is said, were speared. The question arose how many spears a nigger could throw while a soldier was loading and fixing up his old musket. Those who could have answered were all dead. The blacks were hostile then, as they are now. They have had a long immunity from trouble, and that, no doubt, added to the traditions of how they drove the white men away from the fort, and the Malays from the coast, was calculated to make them worse. In the account of the second voyage of the Flying Cloud it will be remembered I mentioned the evidences of the Malays trying to work on the north coast of the island, and the experiences of those wrecked there. So the niggers will think they can predominate until there is a decided influx of Europeans.

Even the chance of being speared must have become very monotonous at Fort Dundas, and, being so isolated, life must have been a mere existence there.

Following a walled roadway out of the fort, we walked inland through park-like country, some of the trees being very fine. About half a mile from the fort we came upon the ruins of what had evidently been a very substantial building. We put it down as the church, as there were several places near it marked out with stones, which looked like graves. We were the first Europeans to visit the spot since the old days. A little further inland we came on a dense jungle, near which were signs of a large nigger camp. There were sheets of bark doubled up and standing on the ground like a V upside down. Some of the sheets were remarkably fine, measuring fifteen feet 
long by three feet wide. This shelter is only used in the wet season, when apparently every nigger has his own sheet of bark. Judging from the appearance of some of the sheets of bark, it seemed as if the niggers had steel tools, very likely procured from the Malay wrecked proas. The majority of the sheets had evidently been cut with stone axes.

In the dry season the blacks sleep in the most inaccessible jungle they can crawl into. A space is cleared just large enough for one, and here, again, every nigger seems to have his own particular bare spot. Sometimes beds are made of palm leaves or grass.

The mode of living by the island niggers seemed rude and wild in comparison with that of the mainland blacks.

At all the fires, which had evidently been numerous but small, there were heaps of shells of the fruit of the tree fern (Cycas Media). It almost seemed as if the fruit were the staple food, for at all the camp-fires we saw on the island there were heaps of these shells. A few mussel and crab shells were also to be seen.

At one of the camps we found scveral bark bags, evidently for carrying water; they were well and strongly stitched with cane. They were nothing like as neatly made as those used by the niggers at Port Essington, and made of palm leaves; those at Melville Island were made of stringy bark.

In the jungle there was some very fine straight timber, which caught the nautical eye of one of the party, and he surmised that while in the neighbourhood we need not want for a spar. 
During our walk near a fresh-water swamp, we noticed some stumps of trees which had been cut with a sawa relic of the old days. We had a look for the garden made by the soldiers at Garden Point, but could not see a trace of it. At the point is a lovely sandy beach, backed by fine forest country. In an adjacent jungle the niggers had very recently been expending a lot of surplus energy, judging from the number of trees that had been cut down, eviclently with stone axes, as far as the large trees were concerned. One of the trees was six inches in diameter. The smaller trees had cleaner cuts, as if hewn with a sharp instrument. Wandering along the beach I noticed two piles of something all overgrown, and being curious, I set fire to the creepers and bushes. When the fire had burnt out I found two large stacks of bricks, the work of the old settlers. The outside ones were black and weatherworn, but inside they were as bright as the day they were made. The bricks were of very poor quality, the clay not being suitable.

Near at hand there was also a little rivulet of fresh water, running into the sea from under dense undergrowth, which rendered it deliciously cool and refreshing.

Naturally, after our long and hot walk, we determined to have a bogie (bath). I was the first to finish dressing and clear out. The sun was up then. Not a second had elapsed after old Sol had gone to bed, when I heard the other fellows, who were still fooling round in the water, yell, snatch up their clothes, and race along the beach as if they were all possessed of devils, and all the time 


\section{IN AUSTRALIAN TROPICS}

striking themselves with their garments. Having seen the nigger tracks perfectly fresh at the stream, it appeared as if they had attacked the bathers. It was not niggers, but sand-flies, which were the cause of flight. The way these flies went for the new arrivals clearly indicated that it was a precious long time since they had had such a picnic. Even the niggers on the island cover their bodies with grease with the idea of protecting themselves from the piercing sting of the sand-fly. I always preferred mosquitoes to sand-flics, and after sampling the Melville Island variety I was further convinced that I was right. As instruments productive of irritation, bad temper, and strong language, I with confidence recommend the sandflies of the tropics.

Before leaving the beach some of the boys made a large figure of a man on the sand. In the dim light it presented a most ghastly appearance, so I expect that some of the niggers got a bad start in the morning, and, no doubt, were terribly exercised in their minds as to what it meant. If they had a devil-devil, they would credit it to the white men, left to work all sorts of mischief to them.

Buffalo did not seem to patronise this portion of the island, for we only caught sight of one.

We crossed over to Bathurst Island and wallied inland As far as we could see there were plains, forest, and dinse jungle. Underfoot the grass and rubibish were very thick; apparently it had been many years since it had been burnt.

Close to one of the beits of jungle we noticed numerous holes recenily dug by the niggers in scarch of yams and 
grubs. We also saw some buffalo tracks. This was the first indication of buffalo on Bathurst Island. Previously it had been thought they were not there. I expect the tracks were made by some old bull, who, after being driven out of the herd, had taken to the water and swum across from Melville Island. Before leaving the island we set fire to the grass just to let the local people know they had visitors. There was a stiff breeze blowing, so we soon had a glorious blaze.

Having landed on MIelville Island at several points, we again crossed to Bathurst Island at a cliff which was indicated on the chart as 'Two canoes on the cliff.' Considering that the canoes in question were seen and noted in 1824 , we did not expect to find them, and we didn't.

During the several days we had been knocking about the Straits we had only caught a glimpse of one nigger, and he was in a clump of mangroves watching us. Whenever we made a shift, signal fires went up. However, one night the blacks secmed to get bolder, for their fires appeared close to the water's edge, abeam of the luggers. In the morning one of the crew found a canoe in the mangroves, close to where we had landed the previous day, and he took possession of it. Immediately yells were heard, and niggers showed up on both sides of the Straits; thus proving, as we suspected, that the aborigines had been close to us all the time. On the Melville Island side it was noticed that a number were hanging back; only about a dozen, unarmed, coming to the water's edge. A crowd of the boat's crew immediately started for the shore. The blacks commenced yelling 


\section{IN AUSTRALIAN TROPICS}

'Arra boom! arra boom!' which was at last interpreted into 'Throw your shooting-irons overboard.' The guns were stowed out of sight, and the yelling ceased. The rifle 'boom' apparently had a familiar sound to the niggers, which did not recall pleasant recollections.

The niggers seemed to be very much taken by the head-dress of their visitors. Several of the Malays parted with theirs ; some, in fact, gave away most of their clothes as well. From the signs made by the niggers, it was judged they had something awfully good in the bush to show the strangers, but having a fairly good knowledge of the funny little ways of the niggers generally, and being suspicious of our Melville Island friends in particular, the overtures were declined. Tobacco and sugar were given to the blacks; the latter they eat greedily. The canoe was returned to them.

My time being about up, it was nccessary for me to make my way back to Port Darwin. So at midnight we on the lugger up-anchor, and with the first of the flood commenced to drop down the Straits.

I shall ever remember our exit from the narrow waters, for besides being undignified, it was attended with considerable danger. It was a lovely moonlight night, such a night as can only be experienced in the tropics, so bright that you could easily read small print. It was the bright, mellow moonlight which seems to cast a veil of mystery on all the surroundings. On this occasion the seeming mystery was accentuated, for we were navigating comparatively unknown waters, passing unknown countries, while on either side of us we knew 


\section{A TROPIC NIGHT}

there were fierce and treacherous men, who would be only too pleased to see us come to grief. The sky was perfectly clear, and when we commenced our voyage there was not a breath of air. The sails, darkened by the heavy dew, were gently flapping in answer to the almost imperceptible motion of the boat, and spars and rigging were outlincd as clearly as if a bright sun were shining. It being spring-tides, we were rapidly carried on our course. I well remember how we sat smoking; watching the ever-changing scene as we floated past patches of gloomy, mysterious-looking mangroves, white sandy beaches, with their dark backgrounds of forest and jungle, and red cliffs standing out boldly and defiantly in the glorious light. The marvellous stillness, which had now and then been broken by the plaintive cry of some night-bird, or by an alligator bellowing or crushing through the bushes, making for the sea, was soon followed by a continuous sound of waters running through the growth bordering the Straits, and past rocks and headlands. This was caused by the increasing strength of the tide. A gentle, favourable breeze sprang up, and we were congratulating ourselves on a speedy and safe passage out of the Straits, when, with a crash, we were hard and fast on a coral-reef. The lugger immediately became the centre of foaming, boiling, rushing, swirling waters, which, in the moonlight, had a wild, callous, terrific appearance. If a man were overboard in such a terrible turmoil, it would have been a case of 'God help him!'

For a few minutes there was a grinding and crushing 


\section{IN AUSTRALIAN TROPICS}

of coral, and then the rushing waters forced us over the reef, only to carry us on to another one. So it went on for nearly two hours, on to a reef, clear, and on again, when with a final crash we were clear of the coral and into deep water once more. During the time the tide and reefs had been playing with us the wind had increased into a stiff breeze, so our position had been anything but enviable. There had been nothing for it but to hang on and let the luggser go. Once clear of the Straits, we found the wind had so increased that it was necessary to recf down, but, as if in compensation for our dangerous expericnce, the breeze gave us a fair lead, so we had a glorious run home.

It was a good thing that the boat was a well-built pearling lugger, or she would have been smashed into matchwood. As it was, the boat came through without any material clamage. The other luggers stopped in the Straits to prospect for pearl shell, but did not have any luck.

On another occasion I paid a visit to the buffaloshooter's camp on the south side of the island. The morning we arrived, the two white hunters, Cooper and Flynn, had had a very unpleasant surprise. Riding out to get in their spare horses, they were attacked from behind by the Myalls. A shower of spears was thrown. Cooper was struck on the shoulier by a barbed spear which penetrated three inches. He tried to draw it out, but not being able to, dismonnted and broke the spear off, then, being unable to mount his horse again, he had to walk back to the camp. Flynn was not touched. 


\section{A SAD END}

Being a splendid shot, no doubt he was quick cnough to send a few forcible hints to the treacherous niggers to make themselves scarce.

We went inland for a few miles, but never a sign of a nigger did we see.

Cooper was sent to Port Darwin for treatment, and in three weeks was back at his work, which I think spealis volumes for the constitution of the man.

Poor Flynn had a sad ending. He was camped with his black boys on the Alligator River, when one evening he started up and said there was a snake in his bed. Although no serpent was found, it was presumed that he had been bitten, for the poor fellow dicd next day. The boys were very fond of Flynn, and I think their action displayed a feeling seldom noticed in the blacks. Thcy dug a grave four feet deep, on the bottom of which they placed a blanket. Then they lowered the body with a small tent over it. After the grave was filled in, the whole was covered with sheets of paper-bark, as if to keep the rain off the poor fellow. The boys then erected a stake fence around the grave, and turned up the ground for many feet, so as to prevent bush fires from reaching the fence. Subsequently the body was exhumed by the police to ascertain if there were any signs of foul play, but such was not found to be the case.

The hunters had a number of mainland boys with them, who were in mortal dread of the island blachs. Severai accompanied us during our walk, and it was easy to see that they tock no risks, every bush we passed being examined, and keen glances beir.y thrown over the 


\section{IN AUSTRALIAN TROPICS}

shoulders to the rear all the time, the islanders having the same playful habit as the mainland Myalls of letting their intended victim pass first, and then trying to get a spear in.

Between Melville Island and the mainland are several islands known as the Vernons, the passage through them being called Clarence Straits. Before the whites settled at Port Darwin the Melville Island niggers were in the habit of working their way across the narrow waters, and making raids on the mainland blacks, and carrying off their women. According to the statements of old black men in Port Darwin, they had encroached as far as where the township now is. Hence the dread those on the mainland had of the islanders. The idea of returning the compliment had not seemed to have entered the heads of the mainland niggers.

The islanders are far and away behind their brethren of the mainland in the manufacture of spears. The Melville Island weapons are big, clumsy things, some ten to twelve feet long, some with single, others with double rows of barbs, and others again simply pointed. Some of the spears found were wonderful pieces of workmanship, considering the crude tools the niggers had, and they must have necessitated a lot of labour and patience. The woomera does not seem to be used on the island, the spears being thrown by hand, the effective distance beingr about fifteen yards. From the above it will be understood that it was impossible for De Rougemont to be saluted with showers of spears, as he said, when running through $A_{p}$ telcy Strats. Arrain, he mentions boome- 


\section{BUFFALC}

rangs, and such weapons are not known in the island. Even at the short distance of fifteen yards the spears are too heavy to be thrown straight, but are projected with a curve and reach the object aimed at in a slanting direction. No doubt Cooper owed his life to this fact.

The spears cause nasty wounds.

Soon after the attack I have spoken of, several of the mainland boys, thinking themselves perfectly safe, sat down to have a smoke, when several spears fell amongst them. One boy was speared, the weapon entering several inches into his back. The wounded man was taken to Port Darwin, but died, it being impossible to remove the portion of the barbed spear from the body. I have the remainder of the spear in my den.

Several of the hunters' horses at different times had been speared by the niggers.

The two hunters mentioned were very successful at their work. During the previous four and a half months to when I visited the island, they shot two thousand buffaloes, one thousand three hundred of these being bagged in a radius of ten square miles of country. The buffaloes on Melville Island are descended from those left by the soldiers when Fort Dundas was abandoned. Although it was known that buffaloes existed there, many thought that they were not numerous, as it was considered that the niggers would run down the calves and kill them, thus keeping the increase in check. Experience showed, however, that such was not the case. Some years ago the island was taken up, the buffaloshooters got to work, and several thousands were killed 


\section{IN AUSTRALIAN TROPICS}

before it was determined to give the place a rest. It was found that the niggers had no idea that young buffalo was good tucker. This accounted for the great increase. The aborigines were meat-eaters right enough, for they killed and utilised kangaroo and birds.

The island buffaloes show decided signs of the effect of inbreeding, especially the cows. Those on the mainland have not deteriorated to the same extent, for they are a mixed breed, as a few of the Eastern Extension Cablc Company's buffaloes got loose many years ago and joined the wild herds.

Amongst the island blacks are some very fine men indeed, but the average is about the same as those at Port Essington. It is generally supposed they are cannibals. Children seemed to be scarce on the island; and judging from what little has been seen of the niggers, the women are badly treated. It was also noticed that some of the men were remarkably hairy. All the niggers scen so far are black, there being no sign of that mahogany colour at times met with on the mainland.

The islanders appeared to have a great reverence for their dead. Their burial-places seen were at a retired spot near their most frequented camping-ground. They were circular, and from ten to twelve feet in diameter, surrounded by upright poles. Some of the posts were twelve inches thick, and were nearly all hardwood. The t.p.ps were decorated, some squared, some rounded, others pointed, and some again mortised right through. The ornaments belonging to the deccased were hung on the posts, the spears being placed between them. 


\section{MELVILLE ISLAND}

In a previous chapter I harc already mentioned that the language of the islanders is totally different from any spoken on the mainland, although the blacks apparently use some Macassar words in common.

The canoes of the islanders consist of one piece of bark, and are upwards of twenty feet long, about twentyeight inches wide, and fifteen inches deep.

The nearest portion of Melville Island is thirty-four miles from Port Darwin. This island contains two thousand four hundred square miles. The island is good pastoral country, and the buffalo.hunters have found by burning the grass judiciously that they can get green feed all through the dry season. The island is full of running creeks and springs, and I think I can safely say it is the best watered country in the Northern Territory. The rainfall is heavy, and the country being undulating retains most of the moisture. Owing to the length of time the island has been stocked, the grasses are better than on the mainland or Bathurst Island. The shooting done proves how weil the buffaloes thrive on Melville Island. Horses also do well, especially in the dry season. The timber on the island is similar to that on the mainland, but much finer. The hunters found some splendid patches of Cypress pine. The country is highly mineralised. From indications seen by the hunters, they firmly believe that silver, tin, and copper exist. The island also has some splendid harbours.

As far as is known, similar conditions obtain on Bathurst Island as on Melville Island. At one time it was supposed that indigenous rubber-producing trees 


\section{IN AUSTRALIAN TROPICS}

existed on Bathurst Island, but such is not the case. However, some portions of the island which have been seen by men who thoroughly understand rubber-growing are pronounced to be excellent for the purpose. These authorities confidently state that no better place could be found for the cultivation of rubber.

This island contains seven hundred and eightysix square miles. The islands together are about one hundred and fifteen miles long and thirty-seven miles broad. 



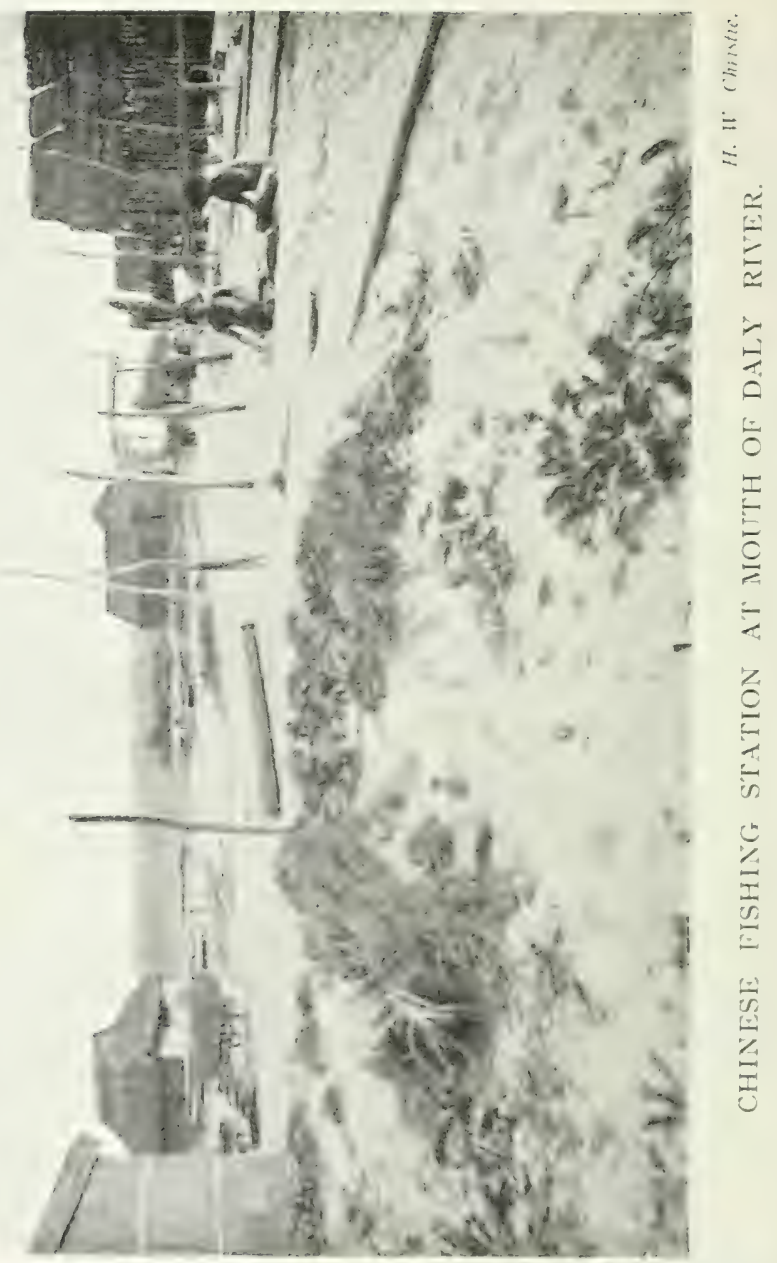




\title{
CHAPTER XIII
}

\author{
THE DALY RIVER
}

Tnis river lies to the west of Port Darwin, and by sea is one hundred miles distant. The entrance, which is two miles wide, consists of extensive mud-flats, carrying from two to three feet of water at low-water springs. The rise and fall at spring-tides is twenty-one feet. Once over the flats, just inside, there is good anchorage for vessels drawing eighteen feet. The current is about six knots. As a stream upon which traffic will one day be both great and constant, the Daly River presents a mixture of good and bad elements. From the anchorzge shallow vessels can ascend sixty miles; but if nature had been inclined to direct its course more as the crow flies, it should be about a quarter of the distance, the channel being most tortuous. The stream offers splendid opportunities for running aground. It has a happy knack of running off the course or changing its current from time to time, perhaps to give the banks a spell. The action of the wet season flood-waters seems to have a demoralising effect upon the bed of the river, and makes banks and shallows where none existed previously, and cuts channels through sandbanks which, before the rains 


\section{IN AUSTRALIAN TROPICS}

were obstacles to navigation. Luchily there are but few rocky patches, and so far, such patches do not seem inclined to shift. Besides, there are the snags-trees washed down by the floods and left stranded in the bed of the river by the receding waters. If a boat should happen to come in contact with one of these impediments, it is soon realised what 'running against a snag' means. No doubt when the day arrives, as it undoubtedly will, for great traffic on the river, the difficulties will be overcome, as they have been in other parts of the world. The more awkward parts of the river have been christened by navigators in their sinful moments, and consequently the titles cannot be published. To the staid and respectable visitor the most troublesome spot in the river would be called Port Botheration.

One noticeable feature of the Daly is the character of its banks. The growth of mangroves is too slight to be obnoxious, and these trees appear only tor a few miles of the course. Then come exceptionally high banks, in some instances supporting jungles, and in others showing.a great extent of open, flat-plains country, which seems to exhaust all its productive facultics in the growth of an immense crop of grass. In the junirle and forest reaches, one sees in abundance immense paijer-bark trees, their branches drooping into the water's surface after the: manner of the willows. Then there are the Leichardt pine, the oak, the wild cotton-trce, nombers of the Eucalyptus family, the flowering acacia, and many other varieties of trees and shrubs. The stunted growth so often met with in other parts does not obtain here. The 



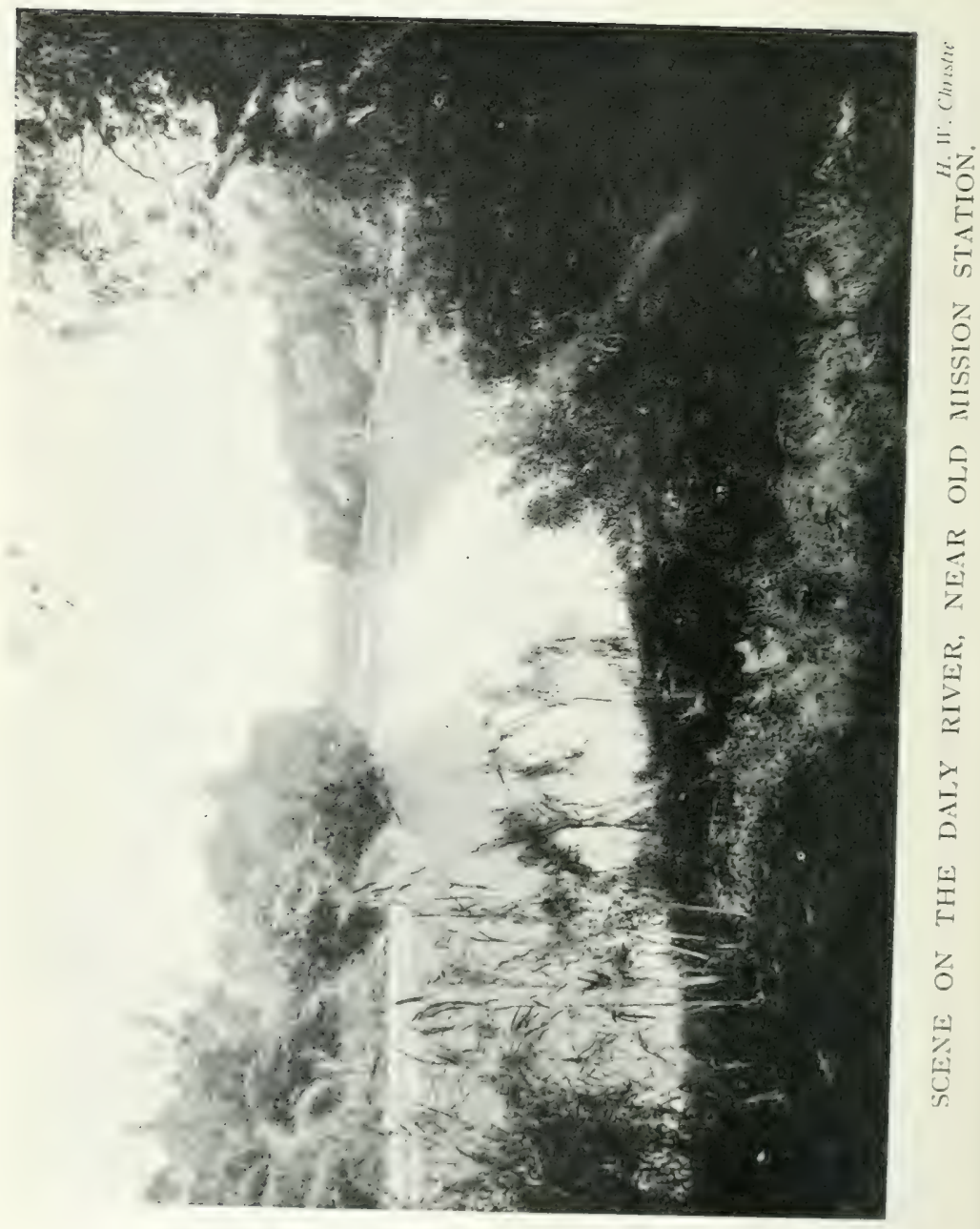


soil is good, and the forestry and vegetation show it. I have visited most of the northern watercourses, but have seen none that took my fancy like the Daly. For forty miles from the head of navigation the river runs fresh, and it is along this that agricultural success can be met with when the proper class of settlers arrive. With the banks as they exist, and a lovely stream of fresh water constantly running below, there is no part of the whole province that could be irrigated at less expense.

The first time I visited the Daly was in my old prize, the Good Intent, when she was bound for a load of copper ore. About five miles from the head of navigation are some very promising copper-mines. At the anchorage we left the ketch, and proceeded up-stream in a steam-launch. I shall never forget the enjoyment I had, when sitting in the bows, watching the lovely changing nature-picture as we glided from reach to reach. The banks were alive with game. On this occasion the birds were left alone, our particular desire being to give the alligators a bad time. Of all the rivers I have been in, the Daly seems to be the most thickly infested with these awful brutes. It always gave me intense satisfaction to know that I had rubbed out a snake, or a shark, or an alligator. Many times we approached what appeared to be logs of wood floating with the current, but when we drew near they would quietly sink out of sight. Many years ago, at Port Darwin, a police-trooper found the difference.

The trooper, who was a great swimmer, and a smart, 


\section{IN AUSTRALIAN TROPICS}

active man, went for a swim early one morning. Noticing what he thought was a log floating quietly down the harbour with the tide, he swam towards it, but quickly realised that he had made a mistake; it was an alligator. With what feelings of horror and dread the unfortunate man must have struck out for the shore! But it was too late; the brute followed quickly behind, and with its cruel jaws seized the victim by the head. In a moment it had disappeared, taking the poor fellow with it. The body was afterwards found on a reef a little way down the harbour. Owing to the noise made by the search-parties in the boats, the brute had evidently dropped its prey in shallow water, instead of carrying it, as alligators generally do, to some lair of their own in deep water.

There were great numbers of 'gators enjoying a sunbath on the sand-flats and mud-banks. In many instances we managed to sneak in fairly close, and had the satisfaction of pumping lead into twenty-six during the afternoon. I have no doubt that many were killed, but we could not make certain, for even their death struggles were sufficient to make them slide down the greasy banks into the water. We had not time to wait and see if any turned up their toes. There was one monster on which we came suddenly, it being only a few yards away. It was asleep, with its mouth wide open. The cavern was towards us, and in a moment our carbines were emptied into the throat. If ever there was a surprised alligator, that was one. It disappeared like a flash. The nigerers do not secm to fear the alligators, for they will freely swim the rivers. They always carry 


\section{ALLIGATORS}

stout sticks, so if encountered they can ward off the interviewer by shoving the stick down the alligator's throat. I have seen several cases where niggers have been mauled by the brutes, the worst one being on the M'Arthur. The poor chap had evidently been caught by the ribs, one of which was showing. We have had instances of blacks escaping from alligators after being caught in their powerful jaws by poking their fingers into the monster's eyes. I wonder how many have the presence of mind to do such a thing. That the alligators are pretty daring we have evidence. I remember a case which occurred on the Roper some years ago.

Several men were camped in a ship's boat, when one of them in his sleep must have put his foot over the side, or allowed a portion of his blanket to hang over. In the early morning there was a fearful shriek of terror. The other men sprang up, and in the clear moonlight saw mosquito curtains and pillows floating in the water, and at the same time realised that one of their mates was missing. For a second a white, ghastly face was seen above the water, and then disappeared for ever.

Although the Celestials have an idea that the alligators will not touch them, we had several instances of Chinese fishermen being badly mauled while following their business. 'Gators like their food high, so deposit on the bottom anything fresh they may secure, and allow it to remain there until it has reached the desired state of putridity. I heard of one nigger escaping after having been deposited on the bottom.

At the time of my visit to the Daly there were two 
Government Survey parties at work about twenty miles from Copper Landing - the head of navigation. We arrived off the camp, which was on the bank of the river, about nine at night. The camp was in darkness, but after a good deal of shouting we roused the fellows out. The Daly is the most beautiful river we have, though it seems to have the most alligators, and I'll back it for mosquitoes. Immediately after sunset it was a case of rolling into your net, or into a mosquito proof-room, or to the leeward of a large smoky fire. Otherwise it is simply Hades. There is no cessation of hostilities until sunrise, when the music ceases, and the bulk of the pests go to roost. The Survey party, to give us a welcome and likewise hear the news, bravely faced the music. We had a great feed of bread, tinned fish, and whisky. One man used a tomahawk to cut the bread, another used a similar instrument as a tin-opener, but the whisky was opened in the orthodox manner. In the morning several of us were sorry that we had indulged in such a hearty supper. Our hats were too small for our heads. It was the fish. After an early breakfast we drove out with the Survey party in their express waggon. There were four horses, and when once clear of the camp, the driver, who was a wild sort of a beggar, sent them along for all they were worth through the scrub and timber. The first portion of the drive was through a cutting made through bamboo grass, eighteen feet high. I, for one, felt rather relieved when the trap arrived at the lagoon, at which we idlers were to amuse ourselves while the surveyors continned 



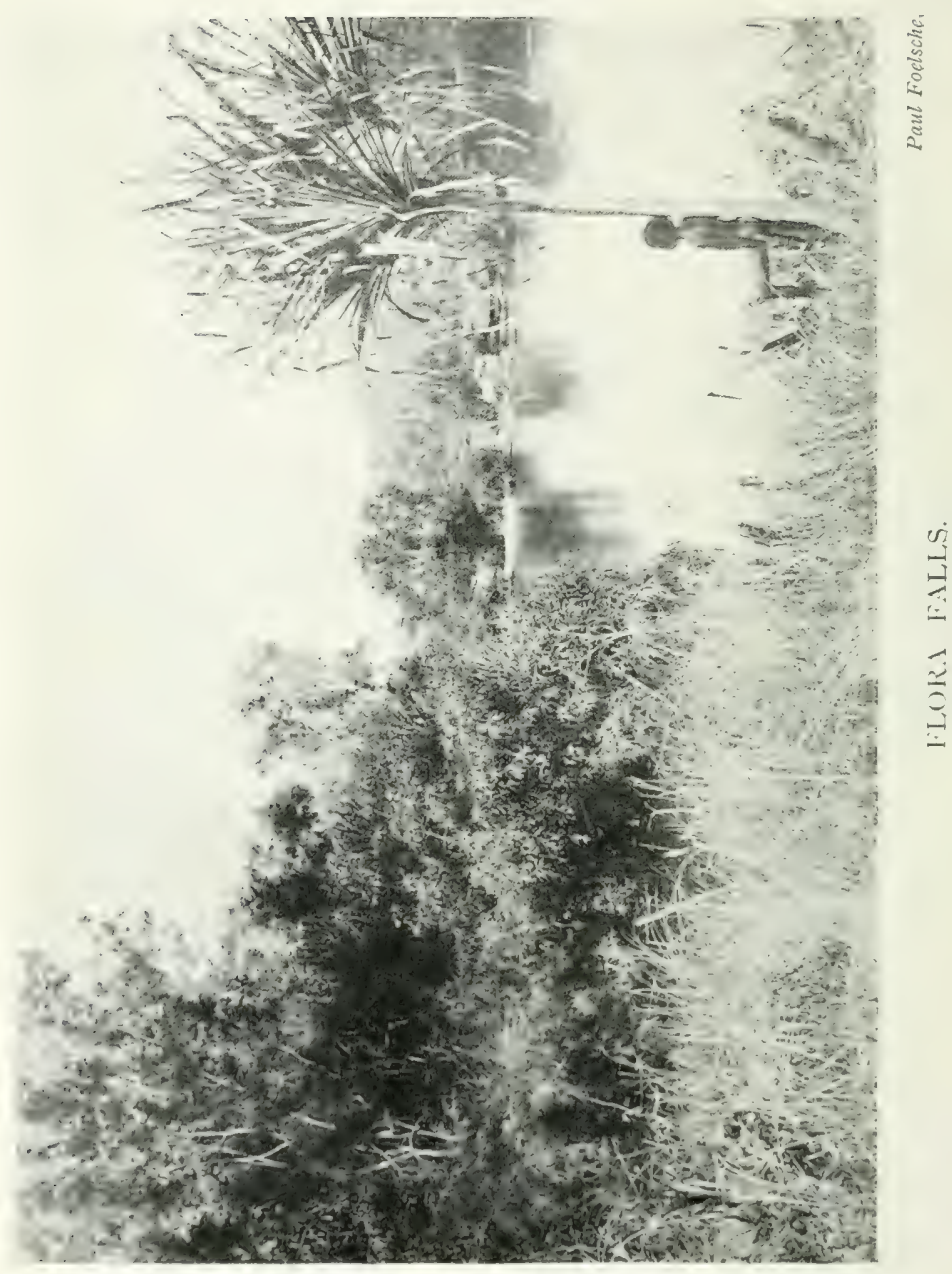




\section{A MASSACRE BY NIGGERS}

their work a few miles further on. On the lagoon were many varicties of game, so we had no difficulty in making a good bag. The lagoon, covered with beautiful lotus lilies, was shallow, and comparatively free from weeds, so the labour of recovering the birds was reduced to a minimum. However, by the time we got back to the camp we were ready for 'bogie' (bath) and a wrestle with a good feed. These surveyors had a ripping cookof course, a Chinaman. In the morning our hats having returned to their normal size, we said good-bye to the surveyor chaps, and proceeded to the Copper Landing. From this point we tramped to the mine, a distance of five or six miles, and received a hearty welcome. At the mine, not long before, had been perpetrated one of those awful tragedies which now and then overtake the out-back settlers. The niggers, from that brute desire to kill and destroy, suddenly attacked the miners, all white men, while at work, and killed three outright, a fourth being left for dead. Another of the party, who was on his way to the telegraph-line, was killed by his black boy at the same time. After the niggers had looted the camp, the man who was left for dead recovered consciousness, managed to crawl away, and was eventually rescued. Although he recovered, to his dying day he carried the marks of the brutal treatment he had received. This was one of the most atrocious and unprovoked murders ever perpetrated by blacks in the Territory. The victims were real good men, who had always treated the niggers with the utmost kindness and consideration. To my idea they erred on the wrong 


\section{IN AUSTRALIAN TROPICS}

side. On the occasion of this murder we had an example of the marvellous manner in which news is transmitted by the blacks to distant tribes. The niggers at Port Darwin knew there had been trouble at the Daly River Copper-Mine a week before the authorities received word. Immediately the news came parties were despatched for the purpose of trying to arrest the murderers and to punish those implicated in the dark deed. There can be no doubt that terrible reprisals took place, but not to the outrageous extent reported at the time. I am afraid, however, that during the excitement some innocent niggers went under. Four or five blacks, the ringleaders, were arrested, tried, found guilty, and condemned to death. A flaw was discovered in the Act under which the blacks were tried, so an appeal was made, and they were eventually liberated. How the niggers must have laughed at us! It had been a number one holiday for the blacks, prisoners, and witnesses. At the same time a Chinese murderer was also liberated. This man had been caught red-handed. The Celestial had entercd a white man's hut in one of the up-country settlements with a view of annexing some goods. The owner objected, so the Chinaman plunged a knife into his neck, which severed the jugular vein. There was an exploring party at the settlement at the time, and they badly wanted to lynch the murderer, but unfortunately the police were there, so the law had to take its course. The Chinaman got a cheap trip to IIong-kong. Amongst the niggers libcrated was one fellow I knew wcll. He was called 'Long-legged Charlie,' a most un- 


\section{BORERS}

mitigated scoundrel. I often had him out shnoting with me when on the Daly. It was noticed that 'Longlegged Charlie' after he was liberated would never go with one man alone, and also that he would never walk in front. I know this for a fact, for I tried him myself. He had an idea, I expect, that an 'accident' might happen, and I honestly believe that he was just about right. There was a very interesting story in Blackwood some months ago, the scene in which it is laid evidently being the Daly River. In this story 'Long-legged Charlie' seems to have received his deserts, but not in the orthodox way.

We camped one night at the mine, but it was not a perfect success, for the borers (beetles) were in the timbers of the hut, and all night long there was the eternal, irritating, grinding noise made by the insects working their way deeper into the wood. The holes made were from the size of a needle-point up to about three-quarters of an inch in diameter, and beautifully true. Borers love young and soft timber. Not far from the Copper Landing was the Jesuit Mission Station. It was in full swing then. It was shortly afterwards closed, and another one opened at a place called Hermit Hill, about thirty miles west of the Daly, but all to no purpose, and it was abandoned. From my experience of the niggers, it always seemed to me that they were perfectly willing to listen to the 'Word' as long as they had free tucker and plenty of tobacco. As an excuse for leaving the mission stations, I have heard them say, 'Too much J. C. all day long ; no more tobacco.' 


\section{IN AUSTRALIAN TROPICS}

Upon our return to the Landing we braved the alligators and had a good swim in the river. However, I might as well mention that we had a big crowd of niggers with us, and their shouting and yelling was enough to frighten away the very devil himself.

My friend Dr. Lynch made a study of the Daly River and Fitzmaurice tribes. We often have long yarns about our experiences in the Northern Territory.

When he first went up to the Territory, the young Adelaide medico did not know much about riding or shooting, or any of the work peculiar to bush life; and although his early experiences were sufficient to make him wish himself further south among his old friends, still he conquered the difficulties and grew to love the life. There were long rides, exciting mectings with swarms of natives, alligator and wild-fowl shooting, and the ten thousand and one incidents peculiar to tropical life. Every one was hail fellow well met, and the doctor knew what it was to give up his bunk to a poor, tired swaggy who was hunting for gold, in the sure and certain hope that if he struck the prospectors' camp outback the compliment would be returned. With a merry and humorous twinkle in his eye, Dr. Lynch told me of one of his first uncomfortable experiences. He was strongly advised not to camp at Blackfellows' Creck-a tortuous stream whose bends the traveller cannot get away from-but unfortunate circumstances compelled that he should. His black boy, who was out of his own country, was just as nervous as the doctor, and the two put in a terrible night with the debil-debils everywhere. 


\section{DR. LYNCH}

Strange noises broke the awful silence; the young medico thought he could hear the pounding of niggers' feet, that sound which remi:ids one of a man walking in the dust. Then his imagination found play, and in the end ran riot. The fantastic forms he saw gradually assumed what he thought real shapes, and he was satisfied there was a black fellow in every bush, and that he could see bright eyes glistening in the darkness. He fired several times at what he thought was a dusky object, and finally he must have become utterly exhausted, as when the dawn was breaking in a wealth of mother-of-pearl, he woke up with his rifle lying alongside of him. 'But I soon got over that,' remarked Dr. Lynch; ' use is second nature, and in the end one would go to sleep anywhere. I became, as most other people do, little concerned about danger. I went among the blacks with perfect confidence. Still, I am of the opinion that you should never trust a black fellow. It is like the tamed tiger tasting blood, there will come a time some day when the black man will turn on you. His savage instincts are easily aroused. The native has an innate desire to kill. It is part and parcel of his being. He thinks the white man is in the country to do something inimical to his best interests, and to exercise a malign influence. He kills the white man on the same principle that the white man kills a black snake. I had a friendly game of cards with a station manager one night. We parted, and went different ways on the morrow. In a few hours my friend had a tomahawk in his head, spears in his body, and his hands and feet chopped off. 


\section{IN AUSTRALIAN 'TROPICS}

'I often had to go out, by instructions from the Government Resident, to the Daly River to investigate cases of reported leprosy. The Fitzmaurice River tribes came into the Daly River several times a year. Both the men and women were of magnificent physique. There was scarcely a man I saw that did not stand six feet high, while the women were of perfect type. Down here the aborigines are black. Up there they are copper-coloured, with aquiline noses, and long, straight hair. In my time they were perfectly wild, uncivilised savages. One would easily think they had a mixture of some foreign blood in them, although the Malay proason account of the trade-winds-very seldom came to this part of the coast, but went in the direction of Port Essington, away to the east. The two people the blacks do not like are the policeman and the doctor. They are frightened of the officer of the law, because they think he will lock them up; and the doctor, because they believe he wili do them some bodily harm on the theory of the debil-debil.

'On August 26, I89I, in company with the policetrooper, I was ordered out to investigate the murder of a black fellow, named Solomon, on the Daly River. We obtained two aboriginal guides from the district, and proceeded ten miles north-west of the copper-mine, the former scene of the Daly River massacre, to Paper-bark Swamp. For the whole ten miles we did not see a nisger. We were apprehensive of danger, and told Twangie-one of the suides-to coo-ce. In response, a black fellow appeared from behind almost every leaf of 



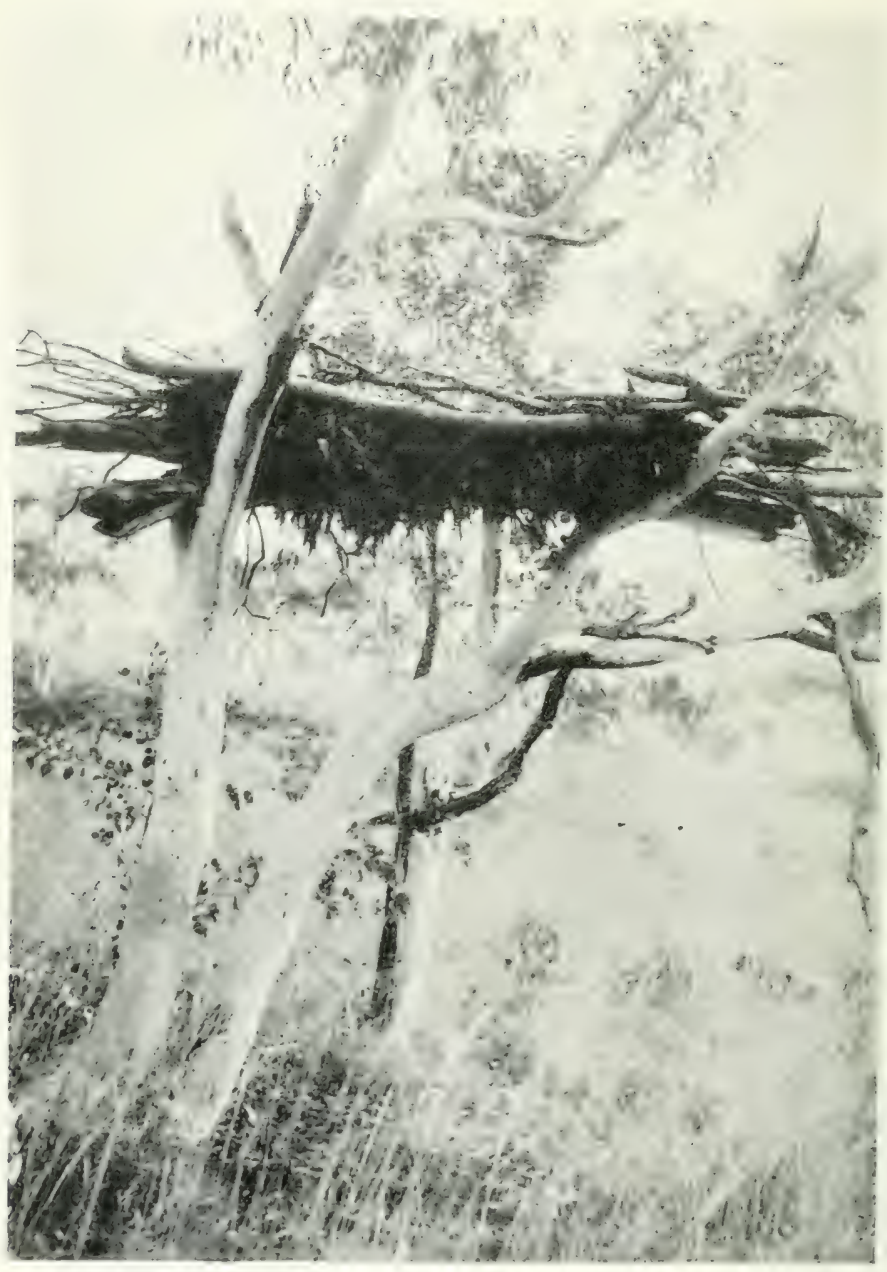

BIACK-FEII,OIN'S GRAVE.

H. W'. Christic. 


\section{INVESTIGATING A MURDER}

grass. They held in their hands the roots of the lotus plant as a sign of peace. Still, we made them come out on to the level plain. Although carrying no weapons in their hands, we were a little sceptical, as the Daly River natives have a clever way of showing their spears when you least expect it. They drag them along the ground with their toes, as I have before mentioned. They saw that our intentions were perfectly friendly. We gave them biscuits, pipes, and beads, which we took out as peace offerings. Glass beads that children string together amuse the niggers immensely. We told the blacks that we had come out to inquire where Solomon was; that we wanted to see his body to find out if he had been murdered, and if so, to try and bring the offender to justice. We knew that a Chinaman had committed the murder. When the niggers saw that we were fricndly disposed they conducted us to a large paper-bark tree, in which the body had been placed on a platform twenty feet from the ground. All leaves and branches of the tree had been cut away, and the trees within a radius of fifty yards had been lopped of their leaves and branches. The body was wrapped in paper-bark, and tied up with jungle creeper. The trooper climbed up and recognised the body, and I followed. I satisfied myself that the nigger had been shot in the neck, from which I removed several pieces of slugs. The nigger had been dead fourteen days, and half of the remains had run down the tree, and soaked into the paper-bark. It was a dirty job. I had a pair of white trousers on before I climbed the tree. When I came down they were piebald. When I 
started away from the Daly River station the niggers tore their hair, yelled out, and wailed most piteously. These were signs of grief. They have a peculiar habit of showing excessive grief by tearing the skin off their noses with their nails.'

Among other things, Dr. Lynch told me that the blacks up in this country are born deceivers. In reply to questions they don't necessarily tell the truth, but something which will please the inquirer. Dr. Lynch tried to learn the native language, and his boy would give him a different word for, say, 'water,' every time he asked him. All the corroborees, chants, and ceremonials deal with phallic worship. The songs and dances are of a most bestial type. A young buck who kills a black fellow is looked upon as a hero, but he who kills a white man is regarded as a god. The murder of the whites is usually planned by the old gins, who carry on the traditions of the race and exercise a sort of witch spell. Up in these parts the niggers indulge in the practice of 'singing a man dead.' Suppose any one dies suddenly, the old women hit on somebody as the cause of the trouble, and the tribe often walk great distances to pick out the victim, and they 'sing him dead.' The poor fellow gocs away into the bush, and literally lies down and dies.

There is a very wonderful bore in the Daly. Two very fine ones came up while we were in the river. The first happened just after we had finished our swim. First there was a loud noise, theil came a wall of water. Our steamer was made fast to the trees on the bank, but by the time the bore had passed every line had been carried 
away. I rather enjoyed the novel sight, for I was seated on the bank, but the fellows on board did not appear to appreciate it. We were under way when the next bore was sighted. The one great heave as the water came up provided a thrilling sensation.

Our next point was a plantation some few miles downstream. When we arrived there the place was in darkness, all hands evidently having turned in. After kicking up a big row, we struggled ashore and found some of the hands out of their nets. They had taken refuge in the dense smolie of a fire which they had stirred up. After being smoke dried we made our preparations to camp. Acting on experience gained, I had rolled up my blanket and net in the moming, so that the fact of unrolling them fixed up my camp. For real out and out, persevering, ambitious, cool, upstanding customers, commend me to Daly River mosquitoes. If you happen to let half a dozen of thuse pests into your net I believe that it is worse than being in the thick of them. Let part of your body touch the net, and those on duty outside get into action, and you quickly shift your position. But those inside are just all over you at once. A chum was with me, and had not taken the precautions I had, so he had to straighten out his blankets before turning in. He had not been inside his net long when I heard some lurid language and the striking of matches. For the next ten minutes I had the pleasure of watching a regular circus. My chum was striking matches and chasing a few mosquitoes round the net. When he got one in a corner he applied a flame to it. After about ten minutes' hard 


\section{IN AUSTRALIAN TROPICS}

going, a box of matches wasted, and language beyond description employed, he cleared the net. Daly River mosquitoes, however, do not take notice of strong language; they are used to it. I knew a man who was so disgusted by the action of a few mosquitoes that had sneaked into his net, that he rolled out of it in a state of nature, saying, 'If you want to have a feed, have it!' and they did.

There are two sorts of mosquito nets in use, one with a hole in the calico bottom to creep through, the other having an entrance in the side, and folding over. When there is no likelihood of receiving a sudden start which necessitates getting out of the net as quickly as possible, I prefer the former. I had a friend named 'Footsack'that wasn't his name, but that's what we called him-who had been in Zululand, and was ever using the word, which I understond meant 'Clear out.' One night when Footsack was up-country camping out, having turned into a net with the entrance bottom side, some of the crowd with whom he was associated thought they would have a lark. Assuring themselves that he was asleep, they all yelled, 'Look out, Footsack, niggers!' The startled one made most frantic efforts to find the exit of his net, but it seemed to have disappeared. He tricd all over, top, bottom, and sides, meanwhile performing the most wonderful acrobatic feats. In a short time he so mixed himself up with his net that he could hardly move. If ever there was a properly trussed man, there was one then, and if niggers had been really on the job, poor Footsack would have had a bad time. It took his 
chums much longer to get him clear of the tangle than it did Footsack to get into the mess. Footsack was a son of one of the best known and respected men in Leeds.

When camping in bad nigger country the usual custom is to sling the net, light the fire, and boil the billy, and then sneak off some distance and camp. Over and over again have fellows found spears through their ncts when they returned in the morning.

As soon as the mosquitoes had said good-morning, I was out in an adjacent swamp amongst the duck, and soon had a nice string. One of the manager's sons accompanied me to the swamp. On his return, his stepmother said, 'Now you will have the fever again; just take a good dose of quinine.' Upon my word I did pity this poor woman, for she was in an awful state from the attacks of sand-flies and mosquitoes. When I saw her she was walking about in flour-bags to keep off the pests.

On the way back from the lagoon we passed the melon patch, and picked an enormous one. When we had finished with half of it the rind looked in size more like a baby's bath. Talking of water-melons reminds me of a resident in Darwin who followed some American recipe he had read. He cut a small hole in a fine melon, into which he allowed two bottles of whisky to soak. It was not bad, and it struck me that it was the easiest way of imbibing whisky without knowing it I ever heard of or tried.

When we left the plantation, we little thought that in a few days it was to be the scene of a terrible tragedy. The manager was an old man, and had a young wife. 
One of the men employed on the plantation was a broken-down gentleman with a failing. He was a very good-looking fellow. The manager thought there was an understanding between the young wife and the goodlooking man. One day the old man sent word that he wanted to see him. On his arrival at the front of the house the old man shot him dead. The manager, who was a Virginian, immediately made for Port Darwin, and gave himself up to the police. At the trial the old man defended himself, and was found guilty of manslaughter. He received two years' imprisonment.

Before leaving the Copper Landing we had been joined by the manager of the mine and his son. While we were steaming down-stream, this son (who was a man) thought that he would have a bath, so he undressed and slipped over the side, intending to hang on to one of the stanchions and get a rinse. We had not noticed the idiotic proceedings. The first intimation we had was to hear a deuce of a yelling, and then we saw the fellow's head bobbing up away astern. I jumped into the dinghy and made after him as hard as I could. The idiot got in the way of the dinghy, so I went right over him. We got him on board eventually, with no further damage than a good fright. I gucss that man would go unwashed for the rest of his life, rather than go through what he did on that occasion. If he only could have scen what was just round Cape Botheration, for we were close to that tribulation of navigators by this time, it is hard to say what would have happened. I have often wondered, if the man had been nailed by an alligator, whether he 



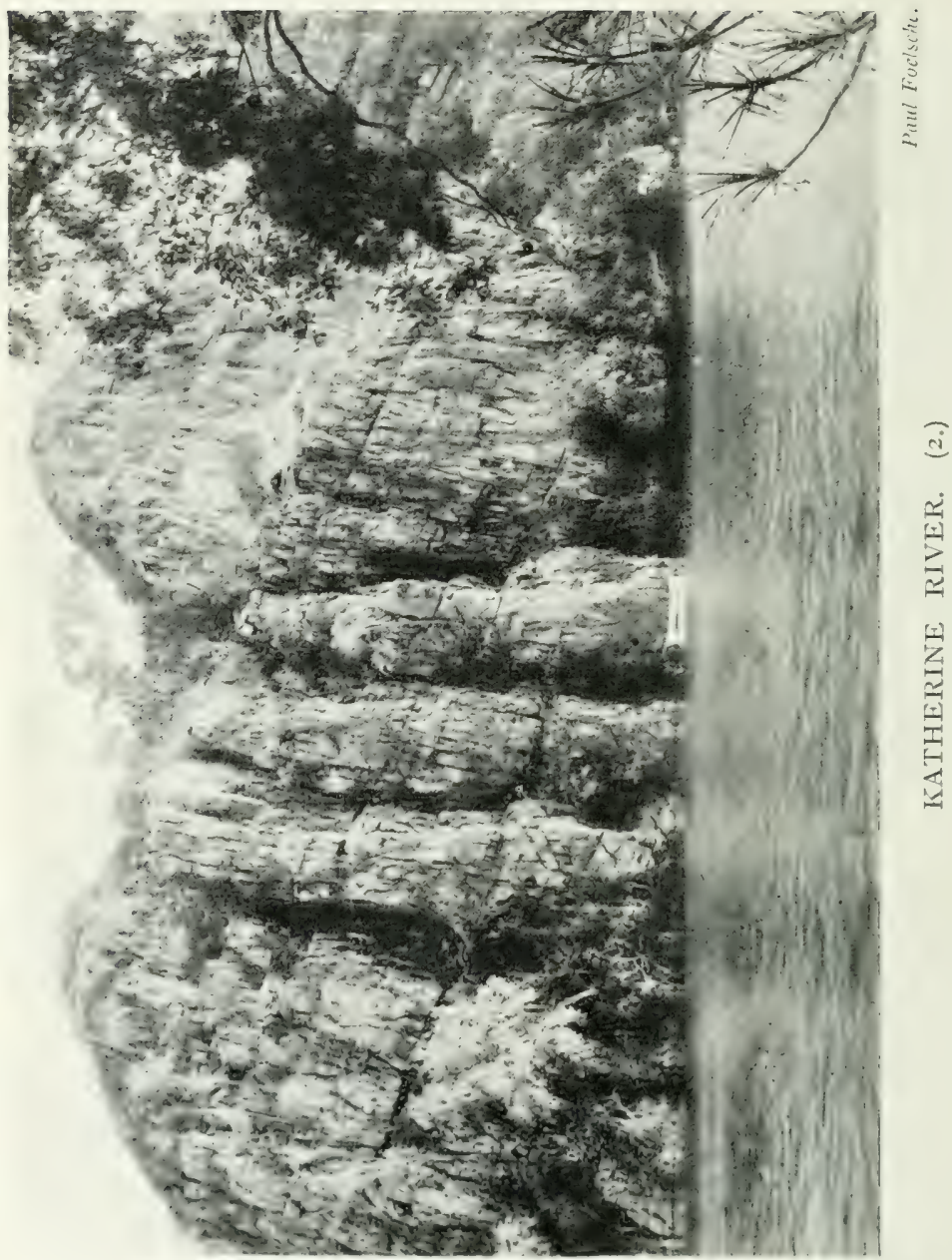


would have had the presence of mind to put his fingers in the brute's eyes. I was anxious to sce the white man who could perform this little act.

As we rounded the point there were eleven alligators on the banks close together. We made preparations to give them a warm time, when the wretched man in charge of the launch became so intent on the alligators that he ran us up on a sandbank about three hundred yards from the spot. Before we got off that man heard several things about himself and his past career that must have astonished him.

Before leaving the river, we anchored to have a final turn at the ducks. The lagoon in which we were shooting was rather deep, the water reaching nearly to our shoulders, which made it awkward. At anyrate we knocked over fifty-six ducks in a short time. On the way down-stream we had secured a kangaroo and two jabberoo. It was my turn to act 'slushy.' I boiled down the bulk of the kangaroo for stock, and in this I stewed the giblets of the fifty-six ducks. To make certain that the flavouring was as it ought to be, I put in a spoonful of everything I could lay my hands on-I mean, of course, everything that was good. The result was simply marvellous. Oh, how the fellows did take to that dish! To this day, several of the men who had the privilege of partaking of this stew praise it to such an extent, that I firmly believe there never was such a stew before, and never will be again. Before we left the river, the niggers gave us a lot of fish. The engineer rather fancied his fish stews. He made one. It was good, but the maker 


\section{IN AUSTRALIAN TROPICS}

was the only man who tackled it, the others being full of giblet stew. One of the Malay boys made a sea-pie out of the jabberoo. We let the boys eat it. During the manufacture of the stew, I roasted a number of ducks. It is wonderful how easy it is to roast birds. Set a saucepan half full of fat on the fire, and let the fat just come to the boil. Then put in the birds, and leep them there until they are brown, by which time they are beautifully cooked, and full of juice. 



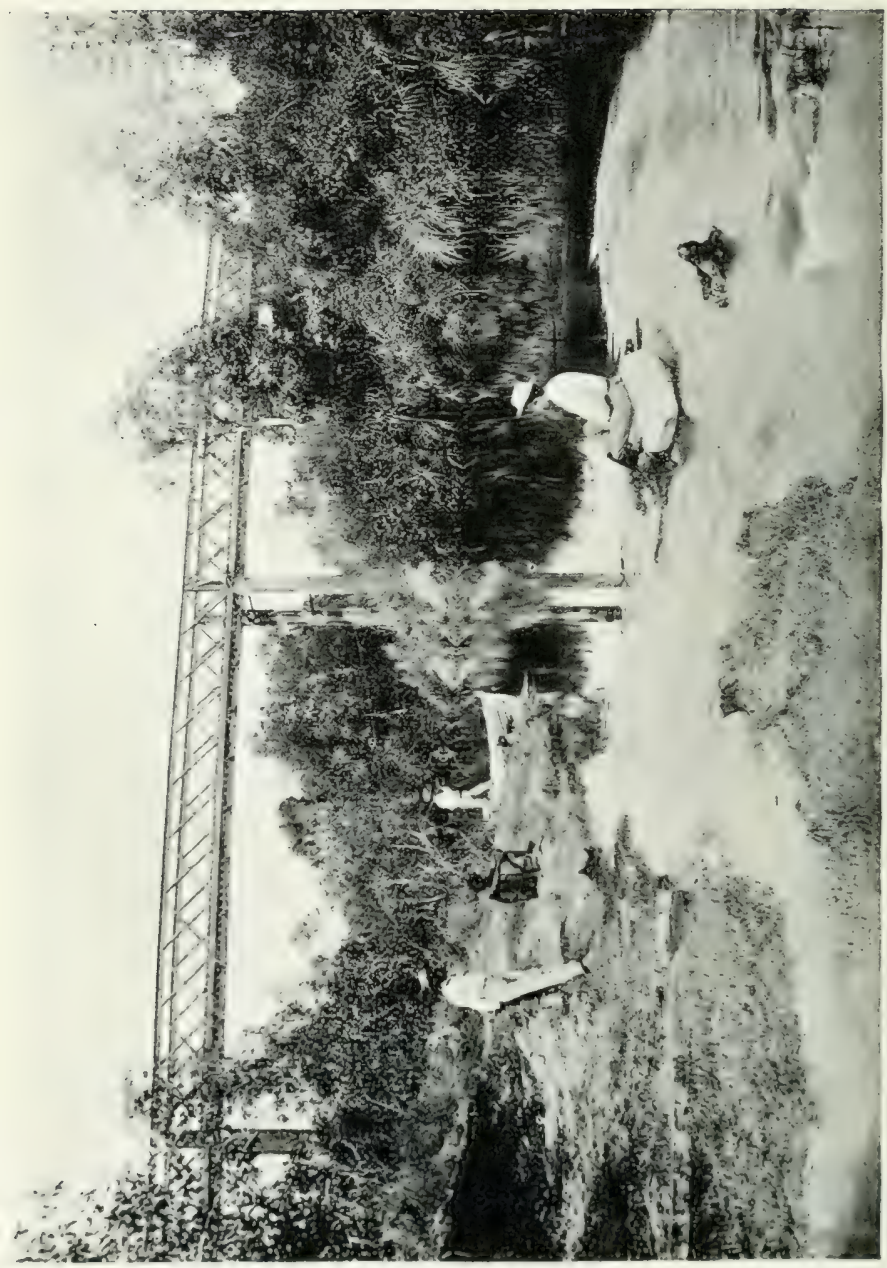

जे
है
0
है
है

$=$

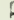

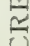

学

ت

II

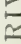

공 


\section{PRIMITIVE WATER-SUPPLY}

\section{CHAPTER XIV}

THE ADELAIDE RIVER AND MORE ADOUT ALLIGATORS

THis river, by sea, is between forty and fifty miles to the eastward of Port Darwin. It can be entered at tidetime by vessels drawing from sixteen to eighteen feet, and once inside, the river is navigable for some seventy miles for vessels drawing nearly thirteen feet. The stream is very serpentine, with short reaches and horseshoe bends. There being such a similarity in the bends and reaches, a stranger soon loses all idea of distance, and consequently his true position.

The s.s. Palmerston being in want of fresh water, it was decided to steam up the Adelaide, and there fill up. At that time our means of supplying fresh water to shipping at Port Darwin was decidedly primitive. The water was drawn from a well by Chinese, and carried down in buckets to a sampan (Chinese boat), into which it was poured. When the boat was full the Celestials would pull her off to the vessel requiring water, and it was then pumped into the tanks on board. It was a mere matter of detail that the boatmen stood in the fresh water. People who are acquainted with the Chinese coolie and Chinese boats can form some idea of how such 


\section{IN AUSTRALIAN TROPICS}

an arrangement appealed to one. What would the doctors, who object to handshaking or kissing on account of the danger of transmitting microbes, think of polluting water in this way. At the present time Port Darwin is more up to date in this respect. The water is now drawn from tanks which are filled from a reservoir, and carried to the end of the pier in pipes.

The late Mr. R. W. Bernard, Superintendent of the Cable Company, and myself went in the steamer to the Adelaide. We steamed up sixty miles into perfectly fresh water. It was a most charming trip, for the Adelaide is a fine river; to my idea it comes next to the Daly. The upper reaches are simply lovely, the luxuriant tropical vegetation growing right to the water's edge. Beyond the belts of timber are broad grassy plains, most suitable for rice-growing. Besides the word of experts on this matter, we had the opinion of several Chinese merchants. The Hon. J. L. Parsons, when Government Resident, took up a party of Chinese merchants to have a look at the river, with a view of forming an opinion as to its suitability for rice cultivation. They were delighted with the plains and soil; in fact, one of them said to me the country 'was all same Saigon,' the biggest rice-producing place in the world. Now these merchants represented a Canton syndicate of Chinese merchants, with immense capital at their back, and were prepared to go in for extensive rice cultivation, provided that the conditions under which labour could be secured were suitable. The conditions were not suitable, and the scheme fell through. 


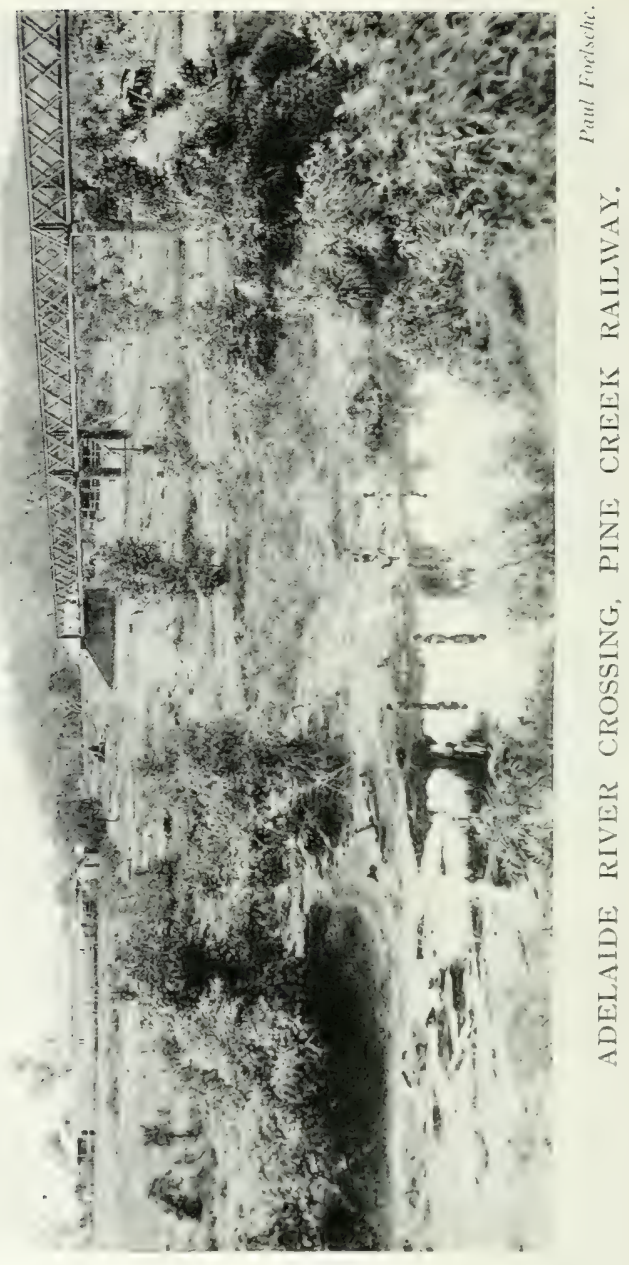


During the wet season the plains are flooded, and the cattle depastured there during the dry season have then to be driven to the ridges at the back of the plains.

While steaming up the river we saw a constant stream of ducks, geese, and nankeen birds flying from either bank.

In the steam-launch we went some ten miles further up the stream, and the same conditions prevailed. Naturally, we had our guns, so soon had as many birds as we required. I also had my carbine with me, on the chance of a shot at an alligator. While blazing away at the birds I suddenly heard a crashing in the undergrowth on the bank. A big alligator appeared, making for the water as hard as he could lay his claws to the mud. It was the work of a moment. I dropped my fowling-piece, and snatched up the carbine and involuntarily pulled the trigger. To my delight and astonishment the brute turned over on its back, and never made another move. That was the only occasion that ever such a thing happened to me. The bullet had entered just under the forearm, and passed right through the body. The brute measured between ten and eleven feet. The carcass was towed to the steamer, and hoisted on board and skinned. That was the first time I participated in the amusement of alligator-skinning. If anybody is anxious to try it, I should say, 'Don't!'

I well remember other experiences I had in Darwin. One day I was sitting in my quarters when a nim (black boy) rushed in and said, 'My word, big fellow alligator sit down along-a bath.' Our baths consisted of an 


\section{IN AUSTRALIAN TROPICS}

enclosure formed by heavy posts and rails, the timbers being sufficiently close to keep out sharks and alligators. I ran down with my carbine, and sure enough, there was a big brute swimming about outside the baths, evidently speculating on the lovely white flesh inside, for there were several men bathing. I had two shots. After the second I noticed that the alligator's tail was churning up the water like the propeller of a big steamer. Guessing that the brute was hard hit, I ordered one of my Malay boys to look out at low water and see if there were any sign of the body. At low water the carcass was found very close to the spot where I shot it. If that had occurred on one of the slimy banks of a river, the alligator would have managed to gain the water and die on the bottom. This fellow was a bull, over twelve feet long. The fatal shot had struck the alligator right in the centre of the forehead. I found the bullet-a Martini-Henry-flattened right out in the brain-pan. How that hide used to haunt me! I shall ever remember the trouble it gave to cure. I was most anxious to make a good job of it, as I was about to proceed south on leave. I used to wake up in the nisht and fancy I could smell the beastly thing, for it did 'hum.' It was the wet season. The head was the worst part. I used to extract the brute's teeth every day and give them a coat of carbolic acid. I was successful, and now the skin reposes in the Aclelaide Muscum. It is the largest specimen of an alligator in the institution.

One of the residents in Darwin, beingr anxious to try alligator, had a piece of the tail cooled, and ate it. 


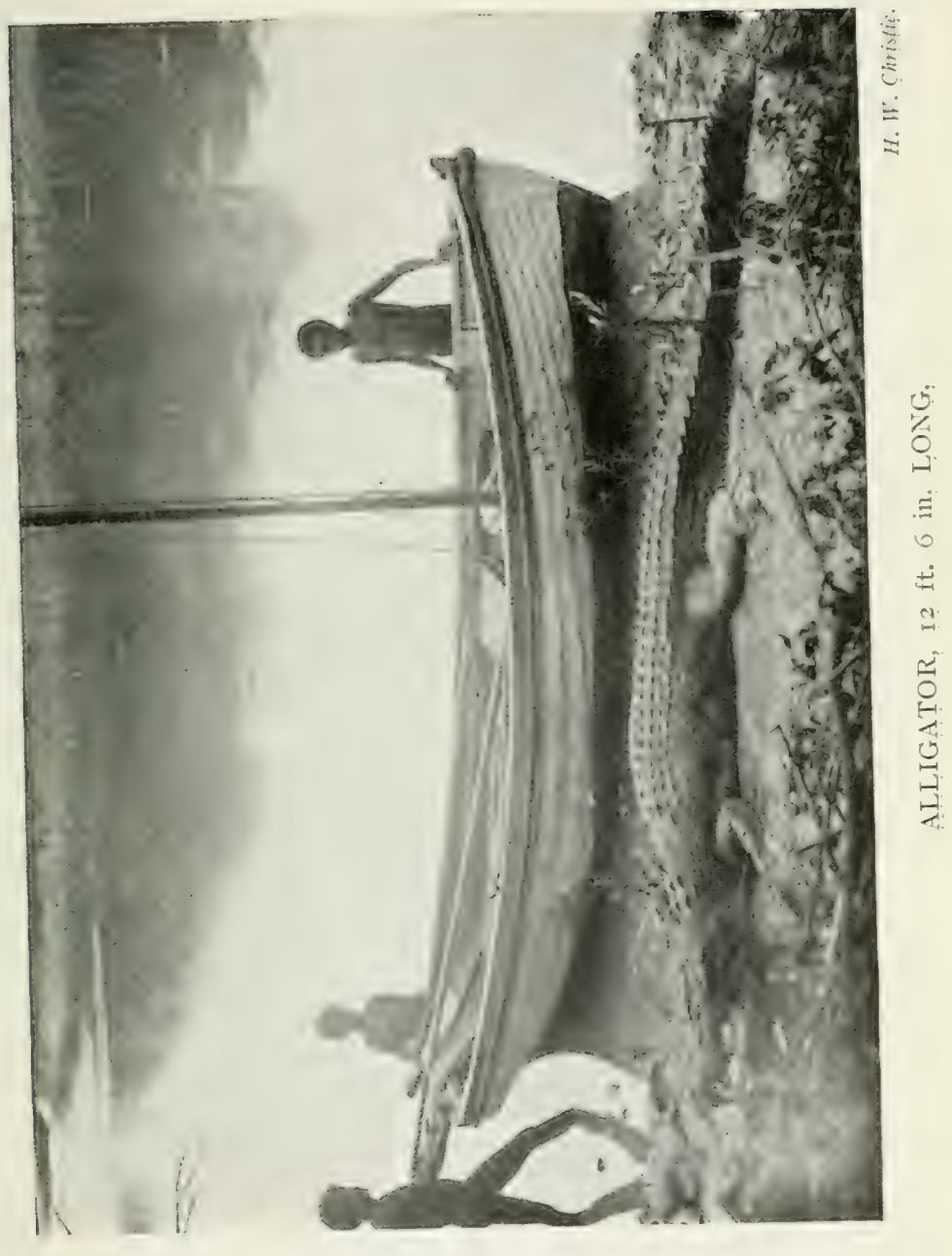





\section{MORE ABOUT ALLIGATORS}

Result-talk about emetics, they were not in it with that piece of 'gator.

Speaking about the baths reminds me of a very sad event which took place there shortly afterwards. A youth of seventeen was bathing, when there was a swirl in the water; the boy gave a most awful cry and collapsed. By the time we had him out he was dead, evidently killed by shock. His body was marked all over with red streaks, just as if a hot iron had been used to make the marks. A man who was in the water at the time, and lifted the boy out, had his arms marked the same way. The pain for some time was agonising. I have at times been slightly stung, but never have I seen anything so bad as the instance I have related. It was generally during the south-easters we were stung. We could never learn what it was that stung us, but we always presumed it was some sort of jellyfish.

A few more particulars about the alligators, and then I will only mention them once again.

On one occasion the niggers brought me in a live specimen, about ten feet long, which they caught in a creek. It seemed well fastened up with ropes, and I put it in the Residency stables until such time as it was convenient for me to kill and skin it. That brute did have me, to be sure. One day it got clear of its lashings, so it can be imagined what a picnic we had to make it secure again, which we did after a great display of energy and cheerful language. We settled accounts next day, and we found forty eggs inside it. One of 


\section{IN AUSTRALIAN TROPICS}

my Malay boys cooked some, which he wanted me to try. I passed. He said, 'All same hen eggs'-and so they were in appearance.

Another live one, a twelve-footer, was brought in by the niggers early one morning. It was well lashed down, and we commenced operations on it. We were proceeding nicely, with great satisfaction to ourselves if not to the alligator, when one of the Malays, in easing off the tail-lashings, gave it too much drift. Suddenly there was a windmill display, and the tip of the tail caught me on the side of the head. I did an involuntary fly, and came down on the Malay, who had a sheath-knife in his hand, which gave me a nasty gash on the left palm. This the doctor had to stitch up, and I carry the mark to this day. I have no doubt that the alligator fully appreciated the joke, and if his jaws had not been bound up, I suppose he would have smiled. We got thirty eggs this time. I expect, if all the little alligators reached the water and lived, the rivers would only contain alligators. The nests are made on the banks, and the eggs hatched by natural heat; and the young ones, like the little turtle, are preyed upon. I remember a man at Southport who had a lot of eggs given to him, which he put away in a drawer and forgot all about. One evening, hearing a noise, he opened the drawer, and found a lot of little alligators.

It is astonishing how simply the natives effect the capture of these powerful brutes. They wait until they sct their intended victim in a shallow water-hole. They then ascertain by means of a long pole where the brute's 
head is, and being satisfied on that point, a rope with a noose in it is fixed on the edge of the water with darkies in readiness to haul it taut. Then by stirring him gently with a pole the alligator is conducted into the noose, the rope is tightencd on his jaws, there is for an instant a splash of water, sand, alligator, and nigger. By means of poles and ropes the tail is soon got under control, the fight is at an end, and nothing remains to be done but to lash the creature securely to a pole, by which he is carried to his doom.

There seems to be little doubt that the numbers of alligators to be found in Port Darwin and adjacent salt arms and rivers have largely increased during late years. By those who have made a study of the subject it is considered due in a great measure to the blacks having practically abandoned their old habits. Instead of hunting as formerly, and consuming hundreds, and perhaps thousands, of alligator and other eggs, they now frequent the town; and this is particularly the case in the wet season. As giving some idea of the extent of the increase of these reptiles, which might take place yearly as the direct abandonment by the niggers of their old habits, Mr. H. W. Christie, head-leeper of the lighthouse at Point Charles, destroyed in one week not far from the lighthouse five allirator nests containing some two hundred eggs, nearly all fertile. This meant a substantial decrease in the alligator population. It is hard to say what would be the result if certain natural enemies did not prey upon the young. In 1902, which was a phenomenally dry year, Mr. Christie went 


\section{IN AUSTRALIAN TROPICS}

for a trip to the Finniss River. The stream, billabongs, and swamps were dry, and this made the alligators take to the tidal part of the river, about ten miles long. They lay like logs all along the banks. Mr. Christie shot some thirty or forty in four days. These were killed where the water was shallow, and the carcasses could be recovered. Many more were shot, but were lost in the deep water. Some authority states that it takes an alligator eighty seconds to turn round. Well, I think those in the Northern Territory are decidedly smarter than that, judging from what I have seen. Christie told me that he saw an alligator throw a back somersault, and nearly grab a nigger who was about to catch hold of its caudal appendage under the mistaken impression that it was dead. Many of the dogs belonging to the lighthouse people have been taken by the alligators. That dog is a favourite tucker with them the lighthouse-kcepers found to their cost. The men one day pulled up a creek not far from the lighthouse in the dinghy, followed by their two dogs, as they had done dozens of times before, when a most agonising and heart-rending howl reached the ears of Christie and his mate. That was all. The alligators had eaten the dogs. One day an alligator was seen to rush out of the water and make for a dog which was on the beach, and followed the canine up with wonderful speed. The dog escaped by the skin of the alligator's teeth. This brute was shot. It measured just over seven feet. An alligator of about that size one day attacked a nigger who was wading in water 


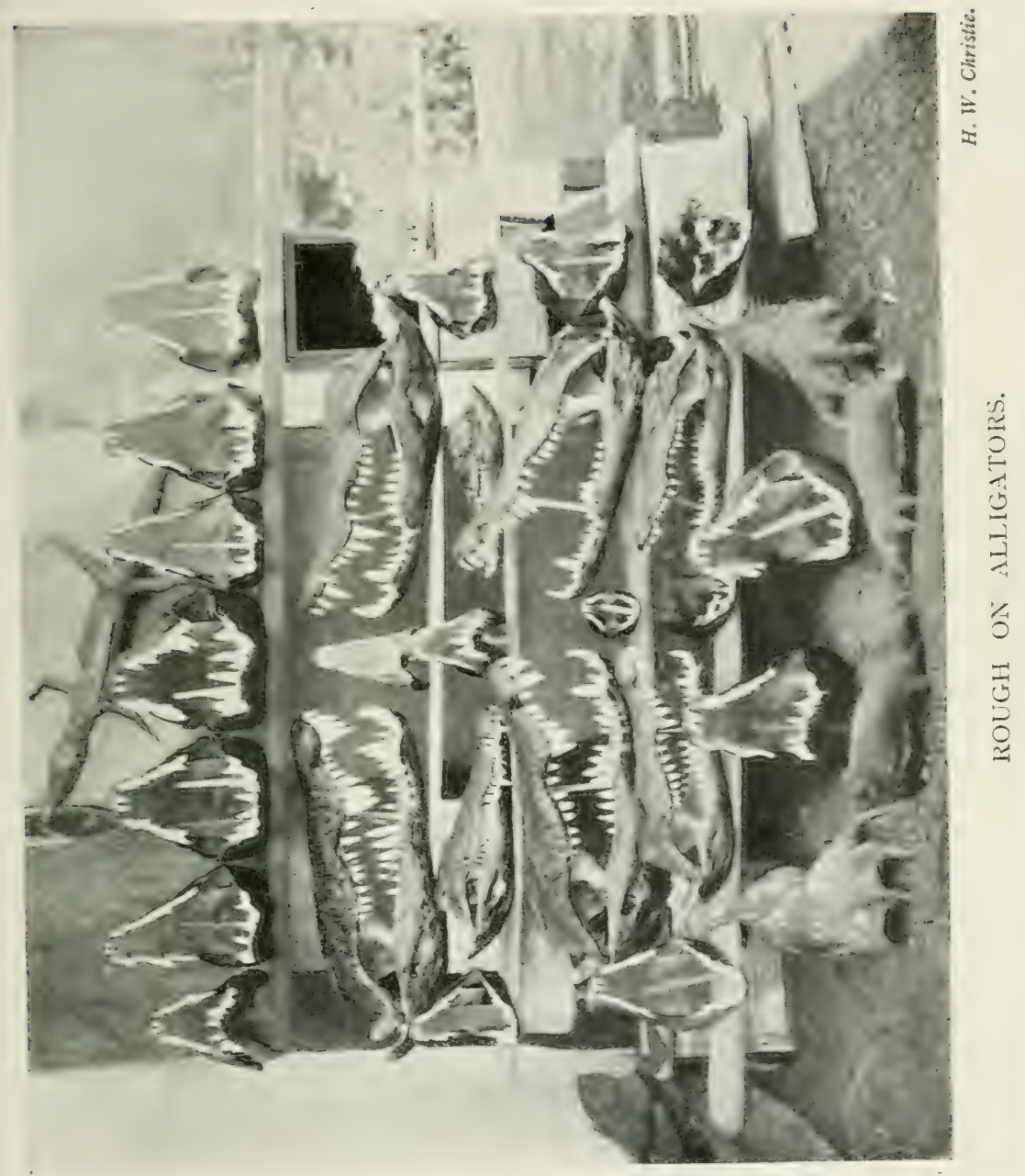





\section{A NARROW ESCAPE}

just above his waist. The reptile caught the unfortunate fellow near the shoulders, tore the flesh clcan off the shoulder-blades, until the very muscles and sinews stood bare. The chest was torn and mangled. The brute also bit the poor fellow's hands very badly. After a terrible struggle the black managed to reach the beach, where he fell exhausted. He was attended to by $z$ doctor, and eventually recovered, but was terribly scarred.

I have already mentioned that niggers had been known to escape from alligators when caught by the monsters, by poking their fingers in the brutes' eyes. It is not long ago that a black in Port Darwin had a marvellous escape. The nigger was swimming off to a dinghy, and was about midway between the shore and the boat when a huge alligator rose alongside of him. The alligator struck the black on the head with one of its forepaws, and inflicted a nasty wound. The next instant the brute seized its victim in its jaws, the tusks penetrating the man's shoulder and back. In this horrible and apparently hopeless position the nigger kept his presence of mind. He was an Alligator River boy, so must have had a good deal to do with the reptiles at different times. With great calmness and courage the nigger wriggled himself round and managed to insert his thumbs into the eye-sockets of the alligator, with such force and effect, that the brute let go its hold and beat a temporary retreat. Torn and bleeding as the nigger was, he immediately dived to the bottom and struck out in the direction of the boat, into which 


\section{IN AUSTRALIAN TROP̈ICS}

he scrambled, having successfully dodged the enemy. However, the brute was not far behind. He charged towards the dinghy, and bit or broke the painter through. The black then managed to paddle the boat ashore before any further demonstration was made by the alligator. As can be imagined from the poisonous character and extent of his injuries, the poor nigger was in a bad way. He would not have anything to do with the 'white pfeller doctor.' His wounds were never properly dressed otherwise than by the application of a little carbolic acid. The nigger finally recovered, but until he is planted away in some tree in his final bark envelope, he will be able to show scars on his person which will be evidence of his terrible fight for life. When questioned concerning his adventure, the black said, 'My word, suppose that one young, strong pfeller alligator, me die quick-that one old pfeller-no more too much strong, quick pfeller.'

I will relate one instance to give an idea of the daring and inquisitiveness of the 'gators. Some years ago Mr. G. R. M'Minn, then Government Surveyor, was camped on the other side of the Port Darwin harbour. IIe slept in a hammock slung between two trees close to the beach. One morning when he roused out he found that his blankets had gone, and at the same time made a discovery which gave him a very uncomfortable fecling. Right beneath his hammock were the tracks of a monster alligator. The brute apparently had scented something in the way of white flesh, so, as a preliminary, har seized the blankets, which were 



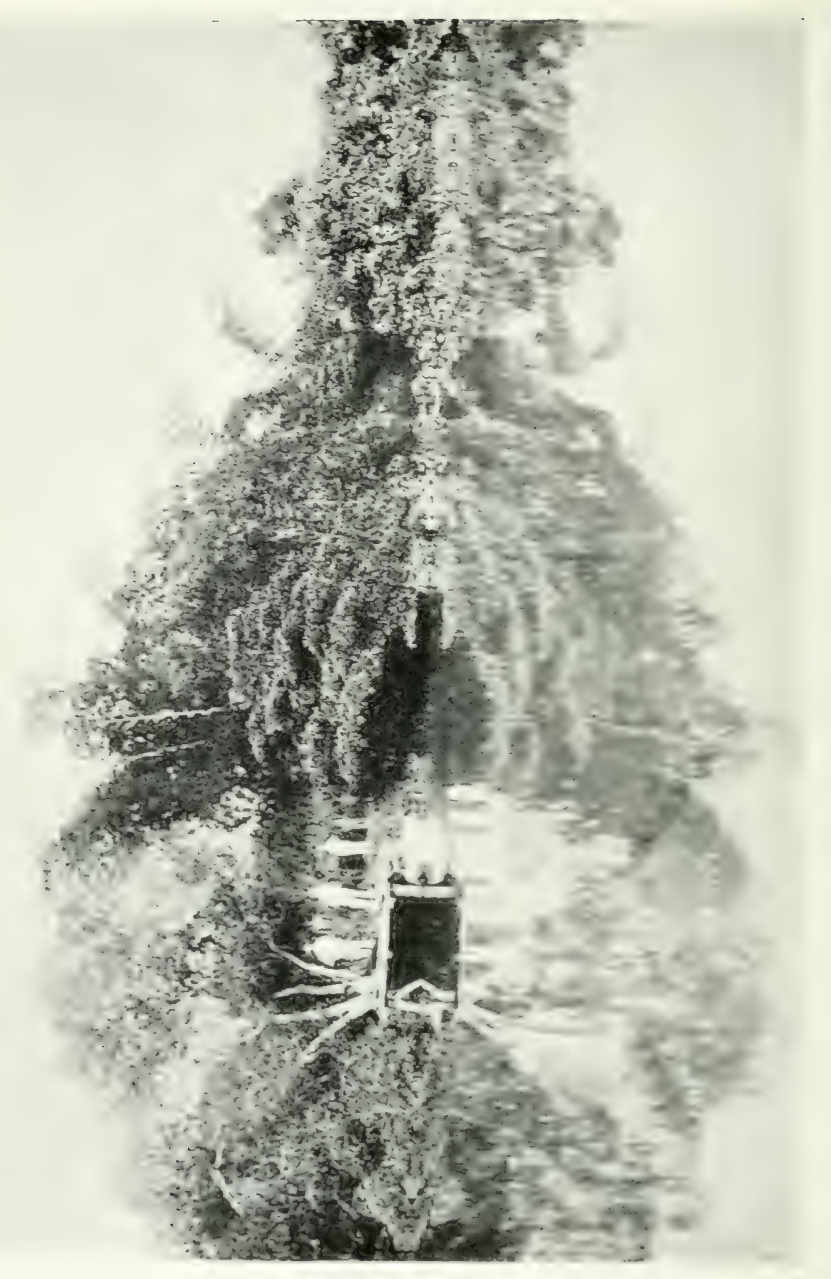

$\stackrel{1}{2}$

$\frac{1}{2}$

$=$

$=$
$=$
$=$

$=$
$=$ 
hanging over the edge of the hammock, and drawn them away, fortunately without taking the slecping man.

To return to the Adelaide River.

We had anchored opposite the Beatrice Hills, which are no distance from the bank of the river, and on which the homestead of the Maraki Cattle Station was formed. Experiments at the homestcad proved that coffee and india-rubber grew there to perfection. The pity of it was that the cultivation had not been carried out on a large scale. What an asset the india-rubber would have been now! After dinner, when off Maraki, we decided to have a look at the niggers, great numbers being encamped there. I ran down the companion to get my revolver, when I thought I had gone clean through the bottom of the steamer. The wretched steward had left the lazaret, which was just at the companion-steps, open. I shot right down and landed on my feet, without having touched either side. Bodily I was not hurt, but my feelings were badly injured. For a time the air was blue, streaked, and striped. I had my cruise ashore for all that.

Having taken in sixty tons of fresh water, we made a start down-stream. When we had steamed a few miles, the steamer's nose was gently forced into the soft bank. We had brought some niggers with us, who knew of a handy lagoon, on which there were numbers of pigmy geese. Now the pigmy goose, with its beautiful plumage, its compact body, about the size of a common duck, was without exception the most satisfactory shooting I ever participated in. Toothsome, too; 


\section{IN AUSTRALIAN TROPICS}

why, none of the other birds were in it with the pigmy. We got ashore all right, the only incident being that I went up to my waist in the slimy, greasy, foul-smelling mud. Almost a mile from the steamer we came on the lagoon. It being only a small one, we three formed a sort of triangle, and so kept the birds in the lagoon. We secured forty-three of the beauties. If ever by chance you go shooting in a swamp or lagoon in which there are plenty of reeds or rushes, and have a companion, let him go first. You will be surprised how easily you will get through in comparison with your friend. I learned the lesson while shooting on a large lagoon. A companion and myself, to save a fairly long walk, started to cross the lagoon. We had ten geese besides the guns to carry. There was not a breath of air, and it was one of the most trying times of the day. We managed to make the centre in a state of collapse; in fact, as far as I was concerned, I did not care if I never got out. After a little rest, however, we had another try, and reached the bank in due course. Another rest and an intervicw with the 'baby' put a different aspect on things, and the killing continued. We brought out our gcese, and I found my chum had walked in my track.

When on the Adelaide on another occasion, I gained considerable satisfaction by passing on the lesson I had learned. We were shooting on a big lagoon, and had good luck. As before, we wanted to make a short cut. A sailor man, a small compact fellow, was put in the lead. The water was about three fect deep, the reeds, 


\section{HOIV TO CROSS A LAGOON}

lilies, and srass being very thick. The leader mate a beautiful track for his followers, likewise he used all the cuss words appropriate for the occasion for a party of our size. When we arrived at the opposite sicle of the laggoon the poor chap was about done up. I then pointed out to him what an idiot he had been to take the lead right through the lagoon, and that he had learned a very valuable lesson. He could only look; all his strong words were in the lagoon.

Near the mouth of the river we noticed that the luclis were in thousands in the large mangrove creck, so away we went to have a final flutter. IVe did it to some purpose, for we made a magnificent bag to take to our friends in Darwin. A monster alligator came up and polied its head right out of the water within two fect of our boat. As a gentle hint that we were not anxious for a closer acquaintanceship, I gave it two charcres of No. 4 right in the centre of the forehead. That had the desired effect. I expect there was a blind alligator knocking about there for some time.

Perhaps my readers may think it is about time I brought in some tragedy in connection with this river, but I am happy to say that none had taken place anywhere near the time of my visit. The niggers were plentiful enough, and quite ready to play up if they had the chance, and they were treated with caution. I have already mentioned the Alligator River niggers as having made things uncomfortable at Bowen Straits. 


\title{
CHAPTER X V
}

\author{
STUART'S TREE
}

THE story of John M'Douall Stuart's trip across the continent in IS6I-2 concerns one of the finest episodes in the history of British exploration. Stuart gained his first experience under that distinguished explorer, Captain Sturt. Previous to setting out on the big trip, John Bentham Neales, in proposing success to the expedition, gave the party nine months to reach the north coast. After encountering almost insuperable difficulties and enduring many privations, the party reached the north shore and planted the Union Jack on July 25 , I 862 , exactly nine months from the time of leaving Adelaide to the very day. The return journey was fearful. The agonies that Stuart suffered can only be understood by his comrades. For four hundred miles he was carried on a stretcher. His body was reduced to a skeleton, and his strength to that of infantile weakness. It always should be remembered that this wonderful trip was accomplished without the assistance of camels, although the party was well equipped with hurses. Some idea of the miles travelled may be gained from the fact that the continent is two thuu and miles 


\section{JOHN M'DOUALL STUART}

across. The public reception in Adelaide was on January 2I, IS63. Stuart sailed on April 25, ISG4, for England, where he died on June 16, 1S66. He was buried in Kensal Green Cemctery. A polished granitc obelisk, erected by his sister, marks the grave. The inscription reads :-

TO THE MEMORY

OF

JOHN M'DOUALL STUART,

South Australian Explorer,

The first who crossed the Continent

From the South to the Indian Ocean.

Born 1815 ; died 1866.

Then in chaste little letters are cxposed to view the words-

ERECTED BY HIS SISTER.

A marble statue has been erected in Adelaide to the memory of Stuart.

The construction of the overland telegraph-line between Adelaide and Port Darwin, which placed the whole of Australia in ready communication with the Old World, might fairly be regarded as a second chapter in the history of Stuart's accomplishments. Certainly the execution of that gigantic undertaking would have been delayed until some years later had Stuart not proved the possibility of crossing the continent. Survivors of the expedition to-day say that the telegraph scheme was constantly in the mind of the great explorer, and he loved to predict that some of his party would live to sce consummated the bridging of the 


\section{IN AUSTRALIAN TROPICS}

continent, not merely by telegraph, but by railway. The man who stands out above all others as deserving of praise in connection with the construction of the overland telegraph-line is Sir Charles Todd.

My father, who was sergeant-major in the Mounted Police force at the time, met and escorted Stuart into Adelaide. I was only a nipper then, but I well remember the explorer and his company coming into our barracks after the public reception. I little thought that some thirty years afterwards I should stand, on the north coast, beneath the tree which the intrepid explorer marked, on the completion of the terrible journey across the dark continent of Australia.

It must be remembered that in the days I speak of everything was done on horseback. There were no camels on which to carry many days', perhaps weeks', supply of water. The terrible uncertainty as to when and how the next supply of water was to come can well be understood, especially as at that time the interior was a veritable terra incognita. Then there were none of the magnificent preserved provisions, nor medicine in tabloids, as is the case now. In fact, the whole surroundings of the old day explorers were as different to those of modern days as is the ancient bullock-wagron to the iron-horse of our day.

Youngster like, I was soon very thick with the men of the party, and particularly keen to see the inside of their packs. I remember one of them gave me a small bag containing a little sugar, which had been twice across the cuntinent. My mother put the sugar in some cakes 
for me to take to school. My cakes were in great demand by my school-fellows.

How the bullets from the cartridges were snapped up, to be sure. Living in barracks, my brothers and myself came in for a good share of them.

Many vain attempts were made during the years following to discover the tree which Stuart said he had marked. In consequence of the non-discovery of the landmark, grave doubts were expressed as to whether Stuart had carried out the great journey which he said he had accomplished. It was in 1883 that the discovery of the silent witness once and for all effectively removed the stigma resting on the great man's name, and under which he died. I well remember the niggers coming into l'ort Darwin with the information as to the whereabouts of the marked tree.

Some years later, with the then Government Resident (Mr. Justice Dashwood), I visited the proof of Stuart's statements. We had to land some miles away from where the tree was stated to be. Before we reached dry land we had to wade through soft mud about two fect decp, and thickly interspersed with rotten coral and shells. Under guidance of our black boys we then walked for nearly four miles across a plain very heavily grassed. When about half-way we had to negotiate a mangrove creek, and while doing so a mighty aroma, which certainly was not attar of roses, struck us. A search revealed the body of an immense alligator, which when on active service was fuliy sixteen feet long. The niggers had evidently been feeding off its tail. Certainly 


\section{IN AUSTRALIAN TROPICS}

a month or two had elapsed since that event. Noticing that the stiff one had some splendid teeth, I thought to myself, 'Old man, I 'll interview you on our return.'

Approaching as we did from the inland side, it could well be understood why the memorable tree was not discovered when the search was made for it, because all the investigations had been carried on from the sea side. Between the tree and the sea were narrow but dense belts of jungle and mangroves. Being just on the land side of the jungle, the tree stood out prominently, because it was the largest one to be seen. The letters J.M.D.S., carved over thirty years before, were still plain. Soon after this it was proposed to cut the tree down, and send the section containing the letters to the Adelaide Museum, but the suggestion was not carried out. At the time, I for one opposed the proposition as a picce of vandalism, but I'm sorry now that the idea was not acted on, for the living monument to Stuart's pluck has been burnt down, a bush fire which swept across the plains into the jungle having demolished it. The dry limb I had cut from the tree can be seen in the photograph. The piece of timber was eventually sawn up and distributed as souvenirs. I was then a curio fiend.

Just inside the tree we shot two jungle fowl. One of our niggers, having received some tobacco from the Resident, deposited it in the tree near at hand. The black then drew in the dust a large alligator, and splendidly done it was. This he requested us not to touch, because 'Bime bye another fellow black man walk along and him one fellow know where tobacco sit down.' 


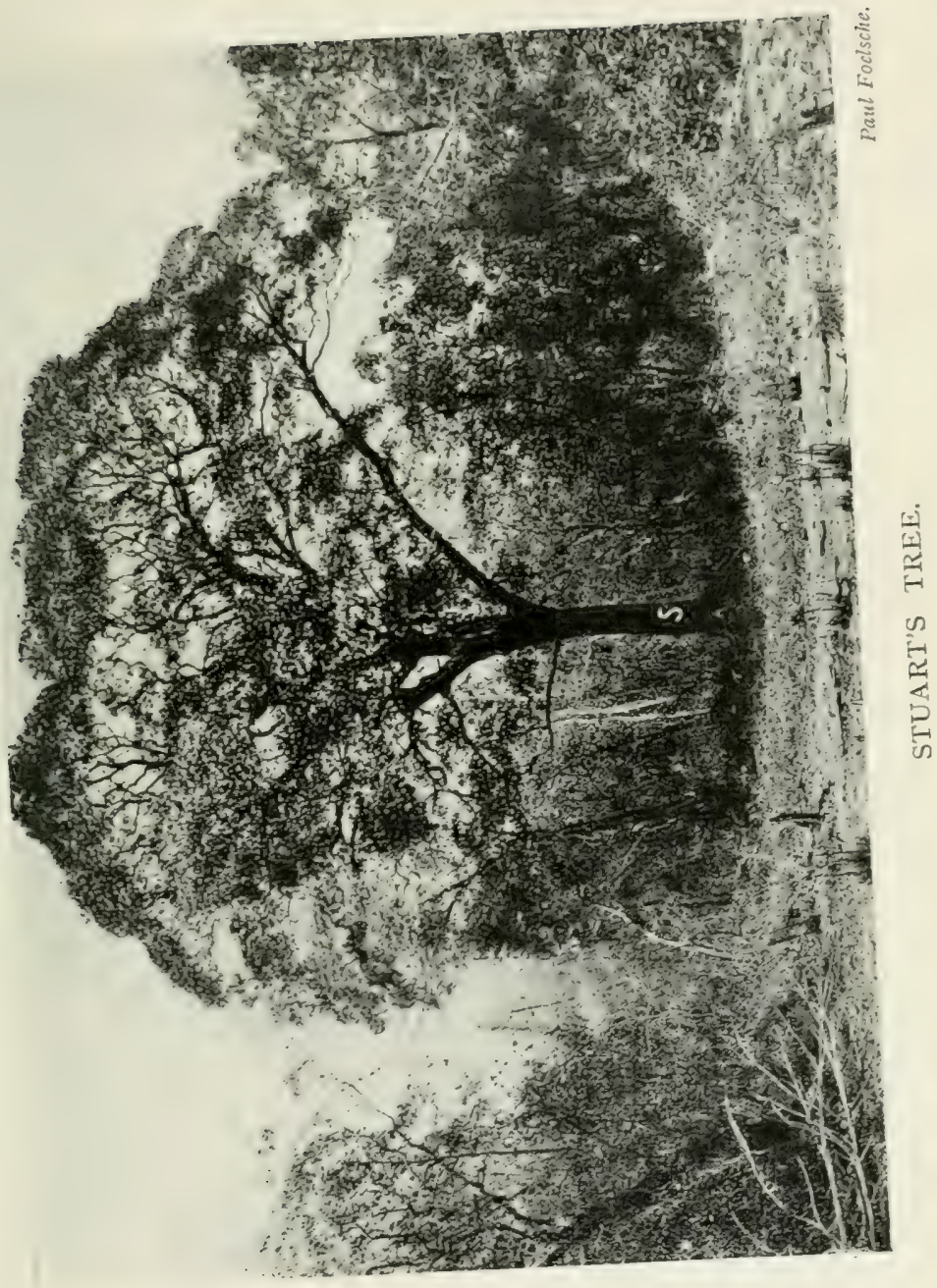



I guess the boy was none the worse off for tobacco owing, to that little act of thoughtfulness.

On the way back to the steamer we stopped at the creek to have our tucker, which we had planted thcre; of course, it was well to windward of the deceased alligator. On curios bent, accompanied by my two Malay boy's, I wended my way to the carcass. I managed to prise open the jaws of the dead brute,phew!-Great Scott! - and held them so while the boys with stones and knives carried out a neat piece of dental work. The teeth were really magnificent, and very large. I sent several of them to Hong-kong, and had them mounted in silver as match-boxes.

Close to where we landed Stuart buried under a tree a box containing papers, but this has never been discovered, the tree either having disappeared, or the box removed by niggers. No doubt the coast-line of that time has altered considerably in the space of thirty years.

The following are the names of the party who accompanied Stuart on that memorable journey, all of whom are still living except Kekwick, Frew, and Waterhouse :Wm. Kekwick, F. W. Thring, W. P. Auld, Stephen King, John Billiatt (in England), James Frew, Heath Nash, John M'Gorrerey, and J. W. Waterhouse (naturalist). 


\title{
CHAPTER XVI
}

\author{
ESCAPE CLIFFS
}

After our visit to Stuart's tree we made for Escape Cliffs, so named by Captain Stokes. On the point of nomenclature I cannot do better than quote from Captain Stokes's diary: 'I shall proceed to explain this remark by relating the startling circumstances from which Escape Cliffs received their name. A few days after $m y$ interview in the dinghy with the natives, Mr. Fitzmaurice went ashore to compare the compasses. From the quantity of iron contained in the rocks, it was necessary to select a spot free from thcir influence. A sandy beach at the foot of Escape Cliffs was accordincly chosen. The observations had been commenced, and were about half completed, when on the summit of the cliffs, which rose about twenty feet above their heads, sucldenly appeared a large party of natives with poised and quivering spears, as if about immediately to deliver them. Stamping on the ground and shaking their heads to and fro, they threw out their long shagery locks in a circle, whilst their glaring eyes flashed with fury, as they champed and spit out the ends of their lones bearis, a custom with Australian natives when in a state of 


\section{ESCAPE CLIFFS}

violent excitement. They were evidently in carnest and bent on mischicf. It was therefore not a little surprising to behold their paroxysm of rage evaporated before the happy presence of mind displayed by Mr. Fitzmaurice, in immediately beginning to dance and shout, though in momentary expectation of being pierced by a dozen spears. In this he was imitated by Mr. Keys, who was assisting in the observations, and who at the moment was a little distance off and might have escaped. Without however thinking of himself, he very nobly joined his companion in amusing the natives; and they succeeded in diverting them from their evident evil designs, until a boat landing in a bay near drew their attention. The foremost of this party was recognised to be the ill-looking fellow who left me in the canoe with a revengeful scowl upon his face. Messrs. Fitzmaurice and Keys had firearms lying on the ground within reach of their hands; the instant, however, they ceased dancing and attempted to touch them, a dozen spears were pointed at their breasts. Their lives hung upon a thread, and their escape must be regarded as truly wonderful, and only to be attributed to the happy readiness with which they adapted themselves to the perils of their situation. This was the last we saw of the natives in Adam Bay, and the meeting is likely to be long remembered by some, and not without pleasant recollections; for although at the time it was just looked upon as a very serious affair, it afterwards proved a great source of mirth. No one could recall to mind, without laughing, the ludicrous figures necessarily cut by our shipmates, when to amuse 


\section{IN AUSTRALIAN TROPICS}

the natives they figured on the light fantastic toe; and the readers, who look at the plate in the frontispiece representing this really serious affair, will behold two men literally dancing for their lives.'

In $18 \sigma_{+}$the South Australian Government, having sold a large quantity of Northern Territory land in England and the colonies, it was necessary that a settlement should be formed on the north coast, the site of the capital fixed, and survey work carried out. A large party was accordingly despatched under a Government Resident for that purpose. The leader for some reason or other passed the grand harbour of Port Darwin and fixed on Escape Cliffs as the site of the first settlement. There was no harbour, and no anchorage within many miles, and no suitable lands for townships. The townships were surveyed, however, but it was found in the wet season that the country was under water. The cxpedition was most disastrous, and resulted in a decided failure. Quarrels between the Government Resident and his officers led to a state of utter disorganisation. The head of the party seemed to lose all control over it. The leader selected Escape Cliffs as the site of the town against the protests and remonstrances of his officers and gentlemen who represented the selectors. But little progress was made with the survey, the party became dissatisfied, insubordinate, and idle. Quarrels took place with the natives, who stole the insufficiently protected stores, and who were punished without discrimination. The Government leesident complained of his officers, and his officers complained of him. Dissatisfaction became 


\section{A PUNITIVE EXPEDITION}

so great that Mr. J. P. Stow, who represented the holders of preliminary land orders, and several settlers purchased a small boat, which they named the Forlorn Hope, in which to leave the settlement. In this boat they ran along the coast for sixteen hundred miles, until they arrived at Champion Bay in Western Australia, and proceeded thence to Adelaide. In consequence of the statements made by the returned settlers, the Government Resident was recalled, and the second in command left in charge. In the face of what had taken place it is not to be wondered at that the party was soon afterwards removed, and Escape Cliffs abandoned. All there is now to show for this terrible blunder, and an expenditure of some $£ 94,000$, is a heap of cannon balls, and an old tank at the mouth of the Adelaide River, and many a bullet I have put through the same old tank.

During the time the first Resident was in charge, several men were speared by the aborigines, one fatally so. In connection with sending out a punitive expedition, as it was grandiloquently called, to have an irterview with the niggers, a very good story is told. I cannot vouch for its authenticity, but a man who was present assured me that it was a fact. The leader of the punitive expedition was a relative of the Government Resident. It seemed that shortly before this a nigger, who was known at the settlement as Dombey, had badly hurt the dignity of the Resident. It was also said he was concerned in the spearing business. At any rate, when the Resident was giving the officer instructions as to how the expedition should be carried out, he said: 


\section{IN AUSTRALIAN TROPICS}

'Now, Freddy, if you see Dombey, before you fire you are to say "Dombey," so he will know why you fire.' One of the men who was standing by, and who had a short pipe in his mouth, covered with his hand during puffs, interjected, 'Yes, Freddy' - puff_-'and if Dombey' - puff-'has a piccaninny with him'-puff-'you must say, "Dombey and Son."

The Resident was great at rifle practice, which was carried out every day, until it was discovered that every cartridge in the settlement had been expended-so the same man informed me-and considering the manner in which the whole expedition was conducted, I can fully believe it. It is just as well that the niggers were not aware of the fact, or it might have been a bit awkward.

It was while the settlement was at Escape Cliffs that M'Kinley, another intrepid explorer, was unwisely sent on an exploring expedition to the eastward before the wet season had set in. In consequence M'Kinley found himself stuck up at the East Alligator River by terrible swamps, heavy floods, and inaccessible ranges. M'Kinley had lost many horses, so he determined to make back to the settlement by water. To do this a craft of some sort was necessary, so the remaining horses wcre killed and skinned, and the hides stretched over a frame of wood ingeniously made by some of the party. The flesh of the horses was jerked for consumption during the voyage. In this extraordinary craft M'Kinley and his party descended the river. When the sea was reached they coasted along until they arrived at the Cliffs, just about done up by anxiety, hard work, indifferent tucker, 
and the smell of the rotting hides, to say nothing of expecting every moment to see a side or the bottom torn out by a shark or alligator. Numbers of these voracious brutes were in attendance on the odoriferous vessel, no doubt watching an opportunity, but for some reason no attack was made. 


\section{CHAPTER XVII}

\section{INHUMAN BRUTALITY}

IN I 885 was perpetrated, to my idca, one of the most cruel and brutal crimes ever committed in the Northern Territory. It is difficult to realise that white men-save the mark! - men of British blood, should have been guilty of such a dastardly offence, for I am afraid that there can be little doubt that white men were the culprits. Such cruelty to dumb animals, especially to the horse, man's, and particularly the bushman's, faithful friend, passes understanding.

Some of the tcamsters engaged in carting goods from Southport to the gold reefs sold to Chinese tcamsters a number of horses. White carters were heard to remark that the Chinese were getting too many teams on the roads, and soon after, cighteen of the animals belonging to the Celestials were missing. Scarch was made, and the poor beasts were found on the Finniss River, some shot dead, some tomahawked, and others hamstrung. Four white men were arrested, and were eventually tricd before a jury of their own countrymen, and acquitted. I do not think anybody was more surprised at the rcsult of the trial than the men charged with the offence. That is all the satisfaction the poor Chinese received. 


\section{A FOUL DEED}

My reason for mentioning this dastardly crime is to write about the fate which eventually overtook the man who was supposed to be the ringleader. I Is name was Rodney Claude Spenser. In I890 this individual was settled at Robinson's Camp at the Revenue Station, Bowen Straits, and was engaged in buffalo-shooting. Spenser was a remarkably active man, and a great shot. He was the hunter whom I previously mentioned as having run alongside a mob of buffalo on foot and knocked over seven while the beasts galloped along. According to Spenser's statement, a black man named Manialucum had stolen a lot of his rice, and had threatened to spear him. This nigger, although he knew that Spenser had vowed vengeance, was in the habit of quictly visiting the black boys' camp at the station. Spenser hearing of these visits, instructed some of his boys to seize Manialucum. One night the instructions were obeyed, and Spenser was made aware of the capture. What a picture the scene would have made! Amidst the humpys of the camp were about seventy niggers standing round with paper-bark torches, carried on high, while many had spears in their hands as well. The flickering flames of the torches lit up the naked black bodies, and the gleaming eyes and glistening teeth showed out in strong relief. On one side of the scene was the white sandy beach abruptly outlined by the water, which was coloured black by the dark night. On the other side of the camp was a belt of gloomy jungle, the leaves of which, wet with dew, now and then stirred by the gentle wind, sent back little shafts of light. In 


\section{IN AUSTRALIAN TROPICS}

the centre of this weird scene was a black man on his knees, held in position by two other niggers. All at once a raging white man burst through the throng, revolver in hand. He rushed at the kneeling nigger, clutched him by the hair, put the muzzle of the revolver to one of the black man's temples, said 'Good-bye,' and pulled the trigger. The foul deed was done. Spenser then fired another shot into the dead man's back. Wishing to implicate the two men who had heid the murdered man, Spenser ordered them to thrust their spears into the body; one refused. According to nigger law, if a man is killed, all who spear or strike the dead body are equally guilty with the one who actually commits the crime. The news of the murder did not come to the knowledge of the police until many months after it was perpetrated. I knew soon after it happened, but word came to me in such a manner that I could not divulge it.

When the Malay proas were down that year, Spenser had been engaged to assist the acting officer at the Straits (Robinson being away on sick lcave), but without my knowledge. It transpired that, when carrying out the work in connection with the proas, Spenser had embezzled two or three pounds. One day I met him when he came up from the coast for a spell. I threatened to have him arrested for the embezzlement. I only did this to ease my mind, and let Spenser know my opinion of him, for I had not the evidence at command to gain a conviction. However, Nemesis was around, for that evening Spenser was arrested on the capital charge. I was on the bench at the preliminary hearing. It being 
somcwhat difficult to follow the descriptions of the black witnesses, I suggested to the presiding magistrate that they should act the scene. This was done. One man knelt down, and two others held him. In fact, they re-enacted the whole tragedy in a most realistic manner. The skull of the victim was on the table in front of us. The prisoncr's face betrayed the fact that the acting of the black man was not appreciated by him. Eventually he appeared before a judge and jury. The prisoner's defence was that it was a case of justifiable homicide, or that at least the lesser crime of manslaughter had been committed. The prisoner elected to give cvidence on his own behalf. This evidence was simply corroborative of the statements already tendered. When Spenser had finished, the judge said, 'It is wilful murder now, or nothing.' The prisoner was found guilty, and condemned to death. The sentence was afterwards commuted to imprisonment for life. After serving ten years, Spenser was liberated. He returned to the Northern Territory, and engaged in trepanging.

In 1904 Spenser proceeded down the coast as far as Arnheim Bay, where he established a camp. 'There he was done to death by the Myall blacks. According to the statement of some of Spenser's own boys, they, while engaged ashore, suddenly heard the boss sing out, 'Bring a rifle; I am speared.' The boys ran to the tent to get the weapons, but they found it surrounded by wild niggers, who threw spears at them. They swam off to the canoes engaged in trepanging some distance from the shore, and so escaped. It will never be known 


\section{IN AUSTRALIAN TROPICS}

whether the victim was caught napping, or the killing was an act of revenge.

We had another case of murder in which white men were concerned, and it made a great impression on me. Two white men were charged with shooting a Chinaman for stealing stores. This occurred in the out-beyond. The jury brought in a verdict of not guilty. The judge who tried the case, on the verdict being announced, looked at the jury in astonishment, said 'Good day, gentlemen,' and walked out of the court. 



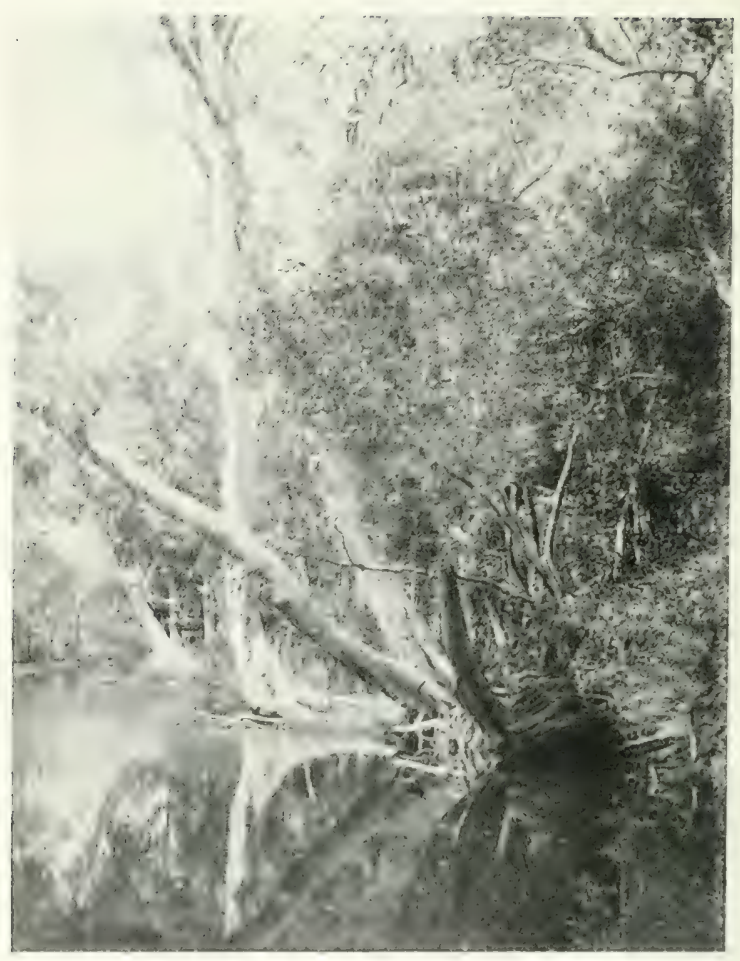

ON THE "IEIIZITIETH."

v. Holtze. 


\section{A SPORTSMAN'S PARADISE}

I HAVE written a lot about the shooting and sport on the rivers and coast, and now I should like to give some idea of how we fared nearer home, that is, in and around Port Darwin.

There are numerous belts of jungle about, some close to the town, others within comfortable driving distance, in which we could always get kangaroo.

A few miles out are a series of lagoons, on which, in the dry season, wild-fowl are plentiful. Generally towards the end of September the geese and ducks would commence coming in from the far-away swamps, their breeding-grounds, to the lagoons near to Darwin. Geese were often shot by the residents of Port Darwin and Southport while flying over at night. They were attracted by the sheen of the white roofs, which they evidently took for water, and would swoop down fairly close. Many a delightful day I have put in at the lagoons and jungles. We would generally make a start at daybreak in a buggy and pair, well provided, of course, with all things necessary to make ourselves comfortable. A few little things I saw to myself, such 


\section{IN AUSTRALIAN TROPICS}

as rope and a tomahawk, in case of a smash, a large canvas water-bag-so there was always clean and cold water; and last, but not least, two good-sized 'billys,' one containing cold curry and the other cold rice. It was such a simple matter to warm the food up for those who preferred it so. I can recommend curry and rice for a picnic. A few miles out was a place called Hungry Flat; but I fancy the name 'Thirsty Flat' would have been more appropriate, for I do not believe we cver passed the place without stopping to take an 'observation,' whether the necessary thirst was felt or not. It was a coincidence that the horses always required a breather at this spot. I soon found out that 'observations' and the desire to quench the carly morning thirst was a mistake. If a great craving for something liquid in the early morning is resisted, it is surprising how long one can go without a drink, and what a lot of exertion can be undertaken. I found this out in hunting. I did better shooting, and managed to get through the severe exertion, if I conquered the overwhelming desire for a drink. But thirst was there all the time; such a thirst too! It was worth pounds; and when one did get something grateful in the way of liquid to his mouth, he would wish that his throat was miles in length.

On our arrival at the desired spot, the horses having been attended to, we would separate, and open ourselves well out amongst the lagoons. As a result the game were kept moving. It was a case of in and out of the water, sometimes nearly up to your ncck and struggling 


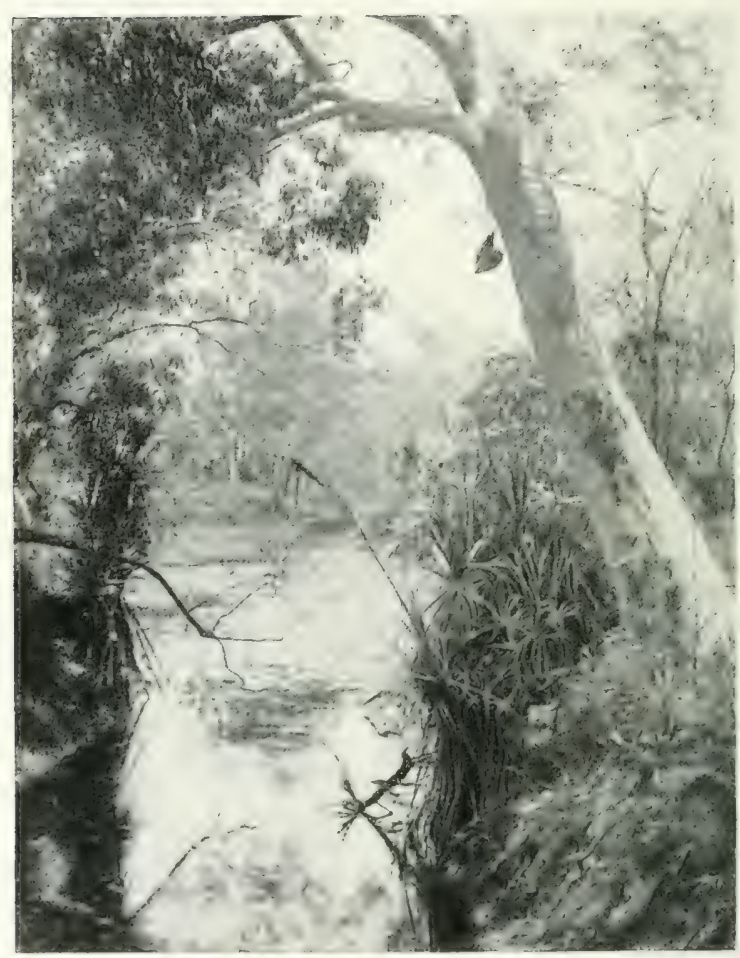

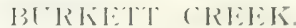

N. Holtze. 
across the swamps, but the hard work was generally well repaid. Sometimes we would arrange to have a lot of niggers with us to do the carrying. They were particularly handy when it came to the matter of getting the game back to the camp. The blacks are very clever at attracting some of the birds. Often have I lain down on the edge of a lagoon with a nigger alongside me, both covered with bushes, when the black would commence to talk 'all same old man goose'only the male birds talk-and so successfully that we would soon have a number hovering around looking for the fellow who was playing hide-and-seek, but a right and left soon let them know that 'old man goose' talk was not necessarily done by one of their number. Towards midday the geese generally flew over to a splendid belt of jungle about two miles from the lagoons, and during the great heat of the day they had a siesta in the trees. Sometimes we would follow them up, but generally made a day of it at the jungle. To vary matters we sometimes put in a night at the swamps or jungle, doing our shooting in the very early morn, and be on our way home before the great heat of the day set in.

Lying in my net, how I used to revel in the sounds of bird-life coming up from the feeding-grounds; the talk of the 'old man goose,' the swish of the whistling duck, and the cries of many other wild-fowl made me long for daybreak, so that I could rouse out and kill something. If it happened to be at the jungle we camped, at the first peep of day I was in the depths 


\section{IN AUSTRALIAN TROPICS}

of it, when everything was wet and dripping with dew, and there was present the indescribable aroma which in the early morning seems to pervade everything. These things, and the deep, church-like silence, the dim, mysterious light, all had a wonderful charm for me. In a short time how everything would change, for soon the shooting would commence, and the jungle become at once alive.

The geese are splendid eating, especially during the early part of the season, but they soon fall off if there is much shooting going on. Besides ducks and geese we occasionally got a shot at a native companion, jabbaroo, turkey, or ibis, but they apparently preferred quieter surroundings, so kept in out-back country and on the rivers. When we were after kangaroo, a number of niggers would be sent into the jungle to drive out the game, and we would keep pace on the outer edge about sixty yards apart. From away in the depths of the dense growth there would suddenly issue a screech from the niggers, which being interpreted meant, 'Lookout, kangaroo walk.' Then soon was to be heard the flop, flop of the animal as it made its way out of the undergrowth for the open country. That was the moment when the fate of the kangaroo was decided.

Some funny things used to take place at times while we were out shooting. I remember one day one of the fellows wounded a kangaroo, and instead of putting in another shot, went for the wounded animal with his gun: result, the stock was broken off short. The niggers did enjoy the fun. One said, 'My word, 'im gun break 'em,' 
and for many a long day he was known as 'Mr. Gun Breakem.'

Our favourite place for kangaroo-shooting was at a spot called the 'Casuarinas,' about twelve miles from Darwin, and near the coast. Our camping-place was anidst the fine Casuarinas growing close to the beach. About a quarter of a mile inland was a grand jungle running for some distance parallel to the coast. There is no mistake we used to put in some glorious days and nights at this spot. On one occasion we invited two of the engineers of a man-of-war, at that time in harbour, to accompany us to the 'Casuarinas.' How gladly they accepted, to be sure, for they had never secn anything of bush-life or camping out. On the way out we sho: two or three kangaroo and a few birds just for immediate use. I volunteered as 'slushy,' so as soon as I had skinned and cleaned one of the kangaroos, I put some of the meat on the coals for our new friends to try. With the balance and the birds I made a great stew. I may say at once the way those Europeans took to my cooking was most flattering. In making kangaroo-tail soup, I never skinned the tail, which was the common practice, but simply burnt the hair off. It made the soup much richer. During this time the niggers had been away getting their own feast ready, in the shape of a goodsized kangaroo we had given them. First a hole was scooped in the sand, in which a large fire was lighted. After a time the fire was cleaned out, and the carcass of the kangaroo put in and covered up with hot sand. When taken out, the flesh seemed to me a bit underdone, 


\section{IN AUSTRALIAN TROPICS}

but to the blacks apparently it was perfection, judging from the way they went for it. A gorge, a sleep, another gorge, and so on right through the night.

The two officers, who were splendid singers, had brought a mandolin with them, so round the camp-fire we had a merry time, the south-east wind having just enough nip in it to make a fire pleasant. I shall ever remember one duet they sang. I do not know the name, but the words which often occurred were 'out with the evening tide.' I have often tried to trace it, but have never yet done so. Over and over again that night those two officers had to sing the duet, to the accompaniment of the mandolin. Nature had provided another accompaniment, for the whistling, moaning murmur of the wind through the fine and wire-like leaves of the Casuarina seemed to blend with the voices most beautifully.

Next day we knocked over twenty-three kangaroo. Needless to say the new chums were delighted. Well, that was more than the butcher in Darwin looked when we passed his shop with our load of game, for few of the townspeople would want meat next day. The liangaroo on the north coast is excellent eating. It often appeared on the menus at the hotels.

There was one thing to be met with in the jungle that I was really afraid of, that was a wasps' nest. Whenever I spotted one I just backed out until the nest was out of sircht, and never said a word. The look of the pugnacious little brutes was sufficient.

Uccasiunally, when the banyan-trees were in fruit, 


\section{WILD PIGS}

we managed to secure a few of the large black and white pigeons similar to those I mentioned in a previous chapter as frequenting Torres Straits. These birds never came in great numbers.

In some of the swamps on the peninsula opposite the township were great numbers of wild pigs. The swamps being adjacent to the lighthouse, the keeper always had something to fall back upon in the way of sport during the dry season, and great fun they used to have amongst the grunters.

On one occasion I nearly bagged a nigger. Hearing a noise in the jungle, I made certain it was a kangaroo, so pointed my gun in the direction of the noise, ready to fire at the first sight. Catching a glimpse of something, I was on the point of pulling the trigger, when a black showed up. That nigger had a narrow escape.

Hunting kangaroo on horseback was followed in Darwin owing to the example set by Mr. J. J. Symes, the leading local solicitor, who at different times imported many dogs for this pastime. It was exciting sport, although difficult, for the country generally was too thickly timbered to be comfortable. I had several turns with Mr. Symes, the last of which I shall remember, for I got a magnificent spill. WVe were sailing along beautifully when my horse's forelegs disappeared in the ground and I turned several somersaults, but landed unhurt. The accident was caused by a cavity left by the roots of a large tree having been burnt out.

For a tropical country I think we were wonderfully 


\section{IN AUSTRALIAN TROPICS}

free from venomous snakes. I rarely saw any in the jungles. The varieties on the north coast were the same as those in the southern portion of the continent. Speaking of snakes reminds me of the Secretary to the Government Resident, Whitelaw by name. He was indeed a cool customer. I have seen him catch a large venomous snake by the neck and hold it so until it was killed. He had done the same thing many times. Owing to his appearance, for he did not have good health, and his cool behaviour, he was known as 'Corpse.' Poor old chap! he one day suddenly verified his nickname.

Amongst the reptiles found on the north coast are pythons. I saw one which measured thirteen feet six inches in length. There is a good story, a true one, told of the killing of a fourteen-footer. It was New Year's Eve, and amongst those who took part in the celebrations was an old soldier, a very powerful and plucky man. Well, next morning the old soldier was found fast asleep sitting in a ditch, clasping firmly in his hands the head of this immense python, his head resting against a bank, and a clove hitch taken in the serpent's tail round one of the rails of a slip panel. Needless to say the python was killed before the old soldier let go his hold.

At our quarters, in the verandah, we always liept a hurricane lantern burning on a table at night. One evening during the wet season, when one of our fellows went for the lantern, he found a large brown snake coiled round it. The snake had evilently come in out 


\section{SNAKES}

of the wet and adopted this plan to get warm, and a warm time it had.

At the Residency one evening I had a very narrow escape. We were at dinner, when word came that a Chinaman had been stabbed during a row in Chinatown. Amongst the guests was the doctor of a man-of-war, and as our medical man was absent up-country, the visitor consented to attend the wounded man. I went with him, and when walking quickly down a wooden stage from the verandah to the compound I felt something soft roll under my foot. Immediately afterwards a large black snake crawled into the verandah, where it was despatched. It was lucky for me that the reptile had not had time or the opportunity to strike, for my thin linen clothes would not have offered much protection. The bite of a black snake is rather deadly.

Besides having a great predilection for chickens and eggs, some of our snakes had a weakness for canaries. Such weakness, as a rule, was attended by fatal results to consumer as well as the consumed. Getting inside the cage was easy enough, but after having enjoyed a meal of canary, the trouble was to get through the wires again. It was generally a case of the 'biter bit.'

In the narne of sport I have put in some hard struggles. I think one of the hardest was through a cane-brake or bamboo grass which towered over my head. The heat was awful. I felt that I should explode. The relief when the open was reached was truly wonderful. Shooting through a sugar-cane field 


\section{IN AUSTRALIAN TROPICS}

satisfied me that active work in such a plantation was beyond me.

At times we shot great numbcrs of black cockatoos. These birds are prized for the tail feathers, which make most lovely fans. I remember when the Duke of Manchester was in Port Darwin, he was so taken with the beauty of the fans that he had several made for presentation in London. I belicve one was presented to the Princess of Wales, our present Queen. As a rule, these birds are rather difficult to get at, but if one should be wounded, it was a foregone conclusion that a good many could be shot, for the cries of the wounded bird always brought the others around. I think the best shooting I had amongst these birds was at Indian Island, a few miles away from Port Darwin, when on our way to have a look at some tin country in Bynoe Harbour.

Indian Island at one time was covered with fine, straight Cypress Pine. The Chinamen soon settled that, and had nearly cleaned the island before it was put a stop to. I don't blame the Chinamen. It was another case of their bcing allowed to do as they pleased.

White cockatoos were also plentiful. I should like to tell you of a famous white cockatoo we had in the Territory. It belonged to a publican at the Adelaide River. That bird could talk and perform in such a manner that certainly conveyed the idea that it was uncanny. I was at the bar of the hotcl one day testing the spirits, when Master Cocky walked in. In a casual sort of way the bird remarked, "What the _ are you 


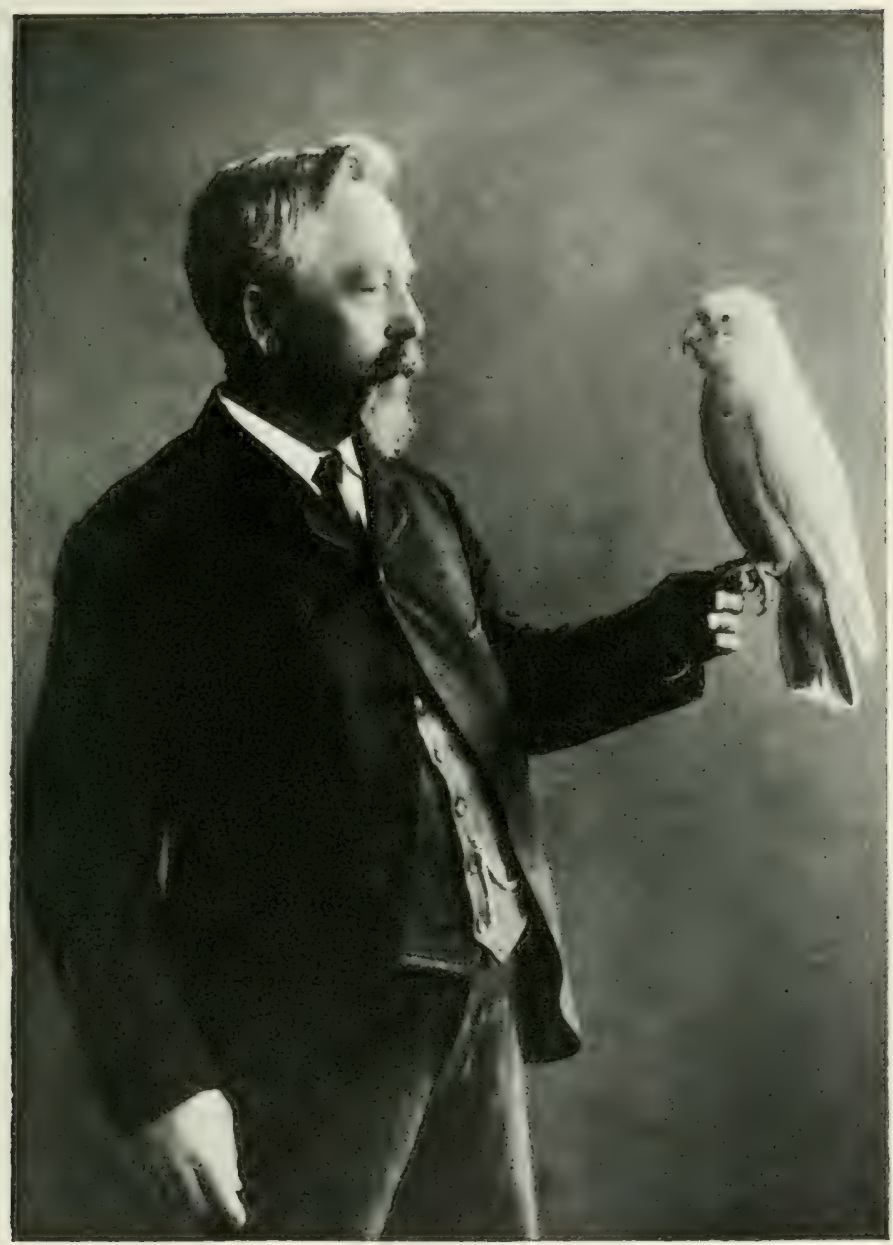

"COCKY" AND HIS OWNER. 

doing there? His owner said, "What shall we do with him, Cocky?' to which query the bird remarked in a matter-of-fact way, 'Oh, turn the —ut.' It sounds a bit De Rougemont, but it is an actual fact. I think the bird's best performance was a dog-fight. Cocky would whistle as if first to get the dogs together, and then there would follow such a growling, snapping, yelling, screeching noise, that if you were not in the same room you would swear a most awful fight was proceeding. This bird used to fly for many miles around its home, and the extraordinary thing is it never came to harm, although it had some very narrow escapes. One of its greatest amusements was starting the teams which had been drawn up in front of the 'pub,' for Cocky was a past artist in the vernacular peculiar to teamsters. One day a friend of mine while at his work, gold digging, suddenly heard somebody abusing him in an awful manner; the language was terrible. The digger, bursting with indignation, leaped out of the hole with the intention of first wiping the universe with, and then walking all over the man who dared to use such aspersions to him, but there was nobody in sight upon whom to operate. He was just commencing to think he had 'got them' when a jeering laugh above him drew his attention to the well-educated but intensely profane Cocky perched in a tree. If my friend had had his revolver with him at the moment, I fancy Cocky would have had a bad time. Pages and pages could be written about this bird's performances, but as it is, I am afraid doubt will be thrown on my statements. 


\section{IN AUSTRALIAN TROPICS}

Still, I can assure my readers that if they take the trouble to communicate with any old Northern Territory resident, they will speedily receive confirmation of the truth of my story. The owner was offered $£ \mathrm{I} 50$ for the bird, but refused; in fact, the only thing that could and did part the two was Death. Cocky died first, the owner soon followed, and now bird and master occupy the same grave.

At certain seasons of the year there are many beautiful small birds, which are trapped in thousands, and exported to different parts of the world. At one time we used to get some splendid parrot-shooting on a small island known as Shell Island, on the other side of Darwin Harbour, which was a favourite campingplace for a very large variety of them. We used to post ourselves just before sundown, under the trees near the mangroves, and wait the coming of the birds. As soon as they happened along, proceedings commenced, and continued until it was too dark to see them. Lanterns were then produced, and a search made for the birds among the mangrove roots. The largest take I heard of was two hundred and fifty. Suddenly the birds ceased to turn up at the island. We put the cause down to the fact that several of the crew of a pearling schooner who had died of beri-beri were buried there.

To give an idea of the effect of any irregularity in the scasons, I will quote Mr. H.W. Christie (bcfore referred to). I might mention that Mr. Christie is an ardent and observant sportsman. 'This year (1905) flocks of geese were migrating in May; this only occurred once before 
during the last thirtcen years. Black ibis came here in flocks; this only occurred once before. Burdekin duchs appeared on the salt swamps; such a thing was never known before. The swamps also are alive with teal and black duck, and the visit of the teal is most unusual. Wild turkeys have come in great numbers, although I never saw them before. Green-back finches also put in their appearance. Shell parrots and cockatoo parrots came in myriads; I never saw them before in this part of the country. Our usual birds, doves, squatter pigeons, pheasants, and curlew are far more plentiful than ever, and are so tame that they come into the verandah. To beat all, there is a phenomenal lot of carpet snakes (Python pilotes) close to the station-some large brutes, too. Thirty-five feet of snake has passed the camp in three days. The question is, where have the reptiles been? for during the last thirtcen years only an odd one has been captured now and then.'

After a hard day in the swamps, what a delight it was to turn into a warm bath, infinitely more refreshing than cold water, and then in light linen clothes to lie out in a long chair and smoke, and puff the cool clouds of tobacco into the tropic night. 


\section{CHAPTER XIX}

\section{DEEP-SEA FISHING}

BESIDEs shooting, I was passionately fond of fishing, and the north coast gives one every chance of indulging in that sport, for it simply teems with fish. The majority of the fish are splendid eating. They are equal, if not supcrior, to anything caught in the south. They comprise grey, red, and golden schnapper, jumping mullet, groper, rock-cod and barramundi, besides other varieties of the names of which I am ignorant. Some of the fish grow to an extraordinary size. A groper was caught at the M'Arthur which weighed six hundredweight. I brought the skull of this fish to Adelaide and gave it to Dr. Stirling. I remember a rock-cod being caught at Port Darwin which turned the scales at three hundredweight. It was sold retail to the Chinamen at sixpence a pound. The Celestials value this fish above all others. It is not the same as the rock-cod caught in southern waters.

For me decp-sea fishing was not a mere hobby but a delight, and in and around Port Darwin I had every opportunity of indulging it. Owing to the strength of the tides, however, our fishing was generally done during neaps, and even then in certain places in the 


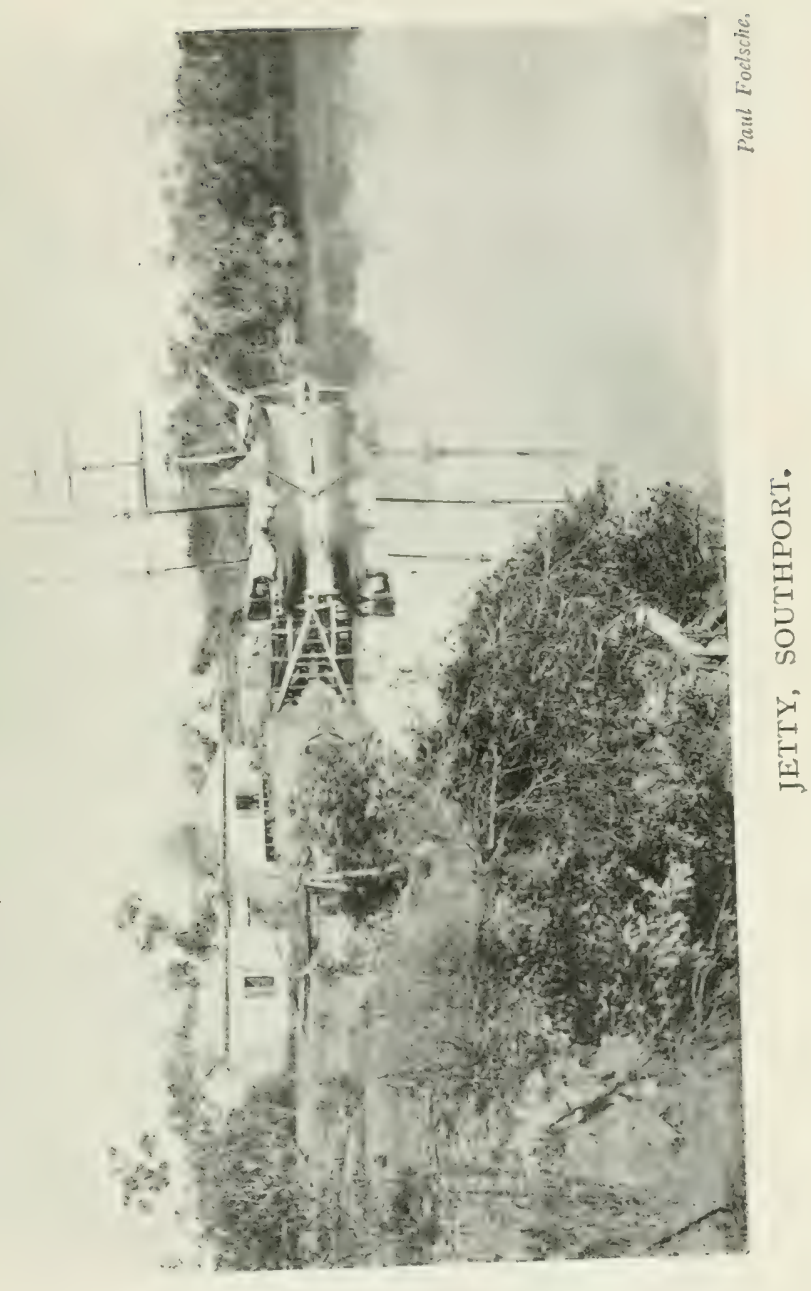



harbour it conld only be engaged in at slack-water. My favourite place was at the mouth of the Blackmore River (so called), but actually only an arm of the sea. At the spot mentioned there is a narrow gut ncarly right across the mouth, the water dropping from five fathoms to twenty-three fathoms. It was rather difficult at times to get into position so as to drop the lines into the dcep water, but once you did you were certain of getting a great catch of all varieties of fish. We called it the 'Town Hall.' I remember on one occasion four of us caught a quarter of a ton of fish in two hours, ranging in weight from one pound red schnapper to thirty-five pounds barramundi. I was fishing with two lines, a fine and a heavy one. Fish do not seem to discriminate, big fellows as often as not going for the fine lines. My fine line was carried away, so I continued with my heavy one. I landed a big fish on board, and fourd that the sinker had fouled the lower portion of the lost line, the fish which had done the damage being still hooked. After playing it for a few moments I manased to get it alongside, and slipped my hand into its gills and so assisted it on board. Not bad in twenty-three fathoms of water. At this spot, when the tide has commenced to run, I have had out seventy fathoms of line with a seven-pound lead before I could get bottom. However, the haul back with a big fish well hooked repaid all the trouble. At times sharks would put in an appearance, and would annoy us by taking the fish off the hooks while they were being hauled in. On one occasion I was lifting into the boat a great barramundi, when there 
was a rush, a snap and a swirl, and only the head remained in my hand. The largest fish caught at the 'Town Hall' during my time weighed one hundred and twelve pounds.

I must explain that the Blackmore is navigable for about twenty-five miles up. At the head of navigation was a settlement named Southport, which prior to the building of the railway to the reefs was the starting-place for all the teams carting goods up-country, the goods being lightered up from Port Darwin. Southport in the old days, besides being a busy place, was a lively spot and the scenes enacted there were truly wonderful. When I was last there all that was to be seen were heaps of empty bottles, and machincry which was imported in the days of the great gold boom, simply rusting away. I must mention one other thing I saw. At the spot where one of the principal Chinese storekceper's shops had stood there was an old cradle falling to decay. The surroundings clearly indicated that some one had bcen putting through the earthen floor, evidently on the chance of some gold dust having been dropped there in the old days when things were flourishing. It struck me that whoever worked the cradle had left mighty suddenly. If that cradle could only have spoken, I firmly believe an ugly tale would have been unfolded.

$\Lambda$ spring-ticles, as soon as the ebb set in, the water rushed out of the Blackmore at a terrific rate. The rushing sea passing over such an irregular bottom as there is at the mouth caused a great swirling, boiling mass of roaring water. In passing through this in a 
big steam-launch I have seen the swirling waters turn her completely round in spite of the helm being hard over. In the harbour there were many deep holes in which we could always depend upon getting fish, provided the tide was suitable. When all things were favourable I always preferred fishing out of a large canoe, which at one time had been engaged in dredging for trepang. When down the coast one year I commandeered the craft. There was a terrible lot of top hamper to take out of her, for on a solid wooden hull the Malays build up a considerable superstructure. My canoe was a perfect model, and was twenty-five feet long, four feet beam, and two feet six inches deep. When it is realised that she was cut out of a solid log, some idea can be formed of the magnificent trees the Malays have to work upon. If I had a strong tide or adverse wind to contend with, I generally used the steam-launch. Owing to the foul bottom we lost many anchors, though all the usual precautions were taken. I invariably used the lid of a four hundred gallon tank, backed by another. The lids held well and never fouled. Fishing as we did in such deep water, to avoid the necessity of hauling in every time we got a bite, we used spreaders, to which were fastened from four to six hooks. At times I have hauled in a fish on each. On one occasion I caught two fish on one hook. A small red schnapper had been hooked, when a rock-cod came along and swallowed the schnapper. I managed to get the two into the boat. The rock-cod weighed forty-five pounds. There is not much fun in catching rock-cod, because there is no play about them, 
just a dead, heavy pull. The Malay boys were most successful fishermen, generally using two lines, one in hand and the other twisted round a big toe. When the fish were on the job this at times proved rather embarrassing. What I used to enjoy as much as anything clse was to leave in my canoe at peep-of-day with the first of the ebb and go right outside the harbour, my sole companion being a Malay boy named Pedro. He could hardly speak a word of English, and I spoke less Malay. He was as mad on fishing as I was, and was one of the most expert fishermen amongst his countrymen resident in Port Darwin. Pedro was a splendid swimmer, and evidently had great presence of mind, as I will show. One day, while landing stores at the lighthouse, there being a heavy sea on at the time, the boat Pedro was in capsized. This left the Malay struggling in the water some five or six hundred yards from the land. It being impossible to get back to the steamer, Pedro, having secured two paddles, struck out for the shore. No sooner had he started than two large sharks appeared on the scene, onc on each side of the swimmer. Pedro did not lose his head, but kept those two sharks off with the paddles until he made shoal-water, and so escaped. He seemed to consider the whole affair as a huge joke. There was great rivalry between Pedro and myself, so we usually kept tally of the fish caught. I do not say that I was an expert, but I know there was little difference between our respective hauls. Sometimes Pedro would be two or three ahead, and on another day I would be 'the ringer.' Some people may be inclined 308 


\section{SHARKS}

to take what I say cum grano salis, but I know from constant practice and carcful observation that I could tell from the nature of the bites the description of fish at the line, even in the deepest water.

Sharks at times were very plentiful, especially if the water were dirty. Needless to say the brutes made a fisherman mad at times. I generally had in the boat an old bayonet attached to a pole for use as a sedative when we hooked a shark of any size and managed to get it within striking distance. Once these pests took to biting -and there is no mistaking a shark-bite-we shifted our ground, for it was almost useless trying for other fish if the sharks were around. We have at times had to shift because we considered the sharks too good for us. I remember once when a monster came alongside my craft. It was about a third less in length than the canoc. I threw a straw bottle-cover overboard for it to try. The shark smelt and turned round with a look which sent a cold shiver down my back. At the same time it seemed as if it were asking the question, 'What are you giving us?' I then gave the brute two or three fish to keep it employed while we up anchor and got under way. The shark could not have hurt the canoe, but it might have bounced us into the water, which would have been unpleasant, if exciting. The only time a shark is of any value is when it is dead, for it makes excellent bait for certain varieties of fish. Another good bait is mullet. My boy Pedro was an excellent hand at securing mullet by means of one of those great circular cast-nets which the Malays use so dexterously. One of the best places 


\section{IN AUSTRALIAN TROPICS}

for netting these fish was at the Leper Station, where there was a patch of sloping sandy beach in between some rocks. When I have been there for bait many a time I have given the lepers a good supply of fish. I remember one poor fellow, a Chinaman, who used to crawl on his hands and knees from the huts to the beach with a dish for his share.

Prawns were undoubtedly the most attractive bait, and all varieties of fish used to go for them freely, the only thing against them being that it took very little to detach them from the hook, especially in very deep water. We used as a rule to parboil them, that having the effect of making them a bit tougher. When fishing one day out of a cutter I hooked an immense ray, fortunately on a strong line. After playing with the fish for some time we managed to get it alongside, and with our sheathknives soon despatched it. It was so cumbersome and heavy, we could not hoist it into the boat, so lashed it alongside and made our way home. The ray we gave to some Chinamen, and it took six of them to carry it to Chinatown.

At one time I had a very fine seine, with which we made some grand hauls of fish. The net was over a hundred fathoms in length, with a depth of fourteen feet in the bunt. However, one day we were trying our luck on the beach below the Cable Station, when we thought we had a tremendous haul of fish. It was not fish we had causht, but a piece of old cable which was sticking up out of the sand. Before we found out what was the mattcr sime thirty feet of the net had been torn away. 


\section{KANGAROO FISH}

Flying-fish were sometimes seen in the harbour, but were not plentiful. There was one very peculiar fish which we called the kangaroo fish, from its habit of leaping out of the water and then gliding along the surface on the tip of its tail for nearly a hundred yards at a time. This fish often jumped into the boats, especially at night. It is about eighteen inches in length, but is no good for eating, being so full of bones, but they want plenty of bones to carry on their antics.

Very few of the Chinese went in for line-fishing. They employed many varieties of nets, which, of course, could only be used in shoal-water. In one description of net the Chinese caught immense quantities of small fish, which in my time used to be served up as whitebait. The Chinese used to stake nets for hundreds of yards alongside the mangroves at high water. Then at low water they would go out and pick up the fish. The Mongolians also used seines for catching fish. I remem. ber the alligators used to play sad havoc with the nets. It very often happened that a swordfish would be taken. I had a sword from one of them which was six feet long. It is said that the fish is four times the length of the sword, but I can hardly imagine that.

Not long after the railway reservoir was formed in Port Darwin, fish were caught in it, but they could only be taken with the fly. They ran up to nearly a foot in length. I don't know what they were, and it is a mystery how they got into the reservoir.

At times some enormous sun-fish visited the waters of the harbour. As in other tropical countries, water-snakes 


\section{IN AUSTRALIAN TROPICS}

were very plentiful, and when cruising about numbers could be seen asleep on the top of the water. When out in my canoe once, sailing over some coral reefs, an extraordinary creature of many colours came to the surface and had a look at us. As far as I could judge, it was seven or eight feet long, the body apparently about three inches in diameter; the head was perfectly round and flat, and about the size of a soup plate. The serpent, if it were one, disappeared before we could get close enough to kill it. I never heard of any one having seen such a brute before or since. We saw it right enough, and another thing, there was no grog within miles of us.

Turtle, both greenback and the hawhbill, are plentiful in the waters round about Port Darwin. The niggers frequently brought them in. Some were of immense size. The turtle, a greenback, in the photograph weighed just two hundredweight. This turtle was caught by its becoming entangled with a strong fishing-line while the lighthouse-keepers were out fishing. It was so well caught that the men managed to haul it alongside and kill it. On the beaches at times turtle were seen which were estimated to weigh five hundredwcight. Mr. Christie, in writing to me about the turtle in that vicinity, says: "The hawkbill turtle (Chelone imbricata) lay from one hundred and ten to one hundred and thirty-seven eggs. The rreenback do not lay about here, but at one time used to do so at Point Blaze. They are the Chelone mydas. The principal eger-layers here are the turtle Democlielys (1)riu.ea Their average would be about fifty, the highest 


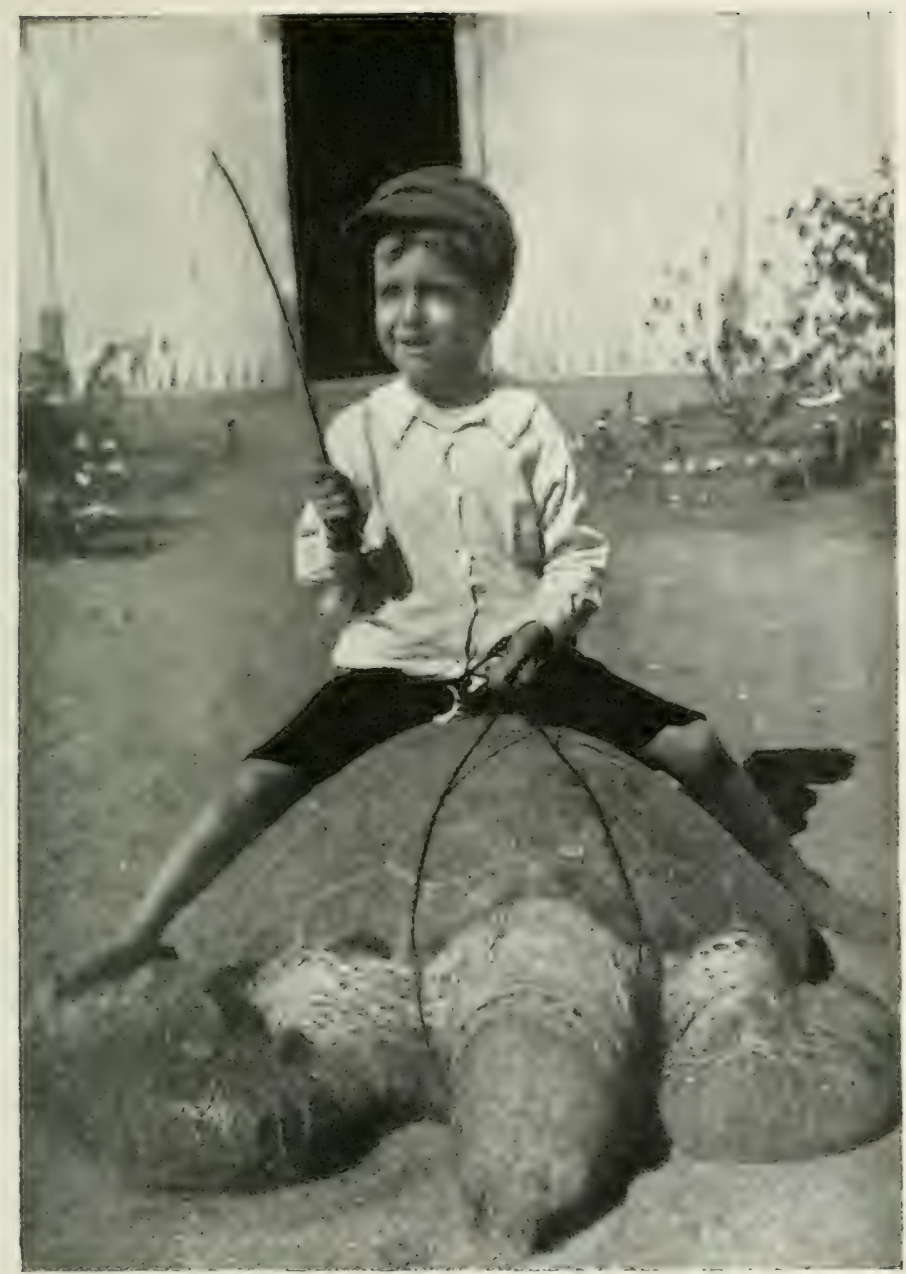

H. W. Christie.

LIGHTHOUSE KEEPER'S SON AT POINT CHARLES RIDING A TURTLE À LA DE ROUGEMIONT. 

number in one nest beingr seventy-eight and the lowest twenty-four. One turtle will pick a beach, and every spring-tide, once a fortnight, will lay five or six times, then leave for some months, and I believe the same one returns. I have persuaded the niggers never to kill these turtle when up laying, and they have acted up to it splendidly; consequently one canoe will bring in a thousand eggs in one trip from Quail Island.

'A fifteen-foot six-inch alligator was killed by the niggers to the west of the lighthouse. His paunch contained all the scales of a fair-sized tortoise-shell. (I have several times found tortoise-shell inside alligators.) We use thousands of turtle eggs annually, and I now prefer them to hen's eggs, especially when made into custard, sponge-cake, tapioca, rice, or sago puddings.'

Christie at times used to get some lovely shell from the niggers. I remember one, a portion of which he sent to London, which realised forty-nine shillings per pound.

Crabs, similar to those I mentioned previously, were plentiful amongst the mangroves in the harbour and in the backs of the salt creeks. I often think what idiotic things we used to do. For instance, when looking for crabs, we have walked up a creek at low water up to our waists in mud, creeks in which alligators were known to be plentiful. If any had appeared on the scene while we were at our crab-hunting, the tables would have been turned properly, and we should have had a lively time. The soft mud would have just suited the alligators, while we could only force our way through the beastly stuff at a yard a minute. It would have been exciting, no 


\section{IN AUSTRALIAN TROPICS}

doubt, but it was just as well that we were not put on our mettle.

Prawns are numerous in Port Darwin. In the season Chinese sampans bring in tons of them. The Celestials dry them and send them to China. When the prawns were spawning, the Chinese, with a very fine net, would catch hundredweights of the young ones, not larger than mosquitoes. In this way millions were destroyed. When in season we had a surfeit of them, prawns curried and cold for breakfast, same for tiffin, and the same with prawn patties for dinner. The Port Darwin specimens are very fine, but they are not things one wants to be eternally eating. Speaking about prawns, Mr. Christie wrote to me as follows: 'The prawns we get here in the billabongs, where the sea has access in the wet season, go up to one foot, tail and head, not counting the feelers, which are another foot. The small prawns are carried in with the tide, and live and thrive in the brackish water away from all their big enemies, and have ample cover in the rushes and weeds. I have never seen prawns half the size in the sea; presumably their many enemies do not allow them long enough to obtain that size. There are two places here where several bucketfuls can be obtained every dry season. The only other place I know of is the lesser Peron Island. When I was there the water in a lagoon had evaporated, leaving a crust of salt, and all over were tons of fish, prawns, and even big crabs. Dried as they were, the prawns struck me as being immense. The niggers reckon they are much bigger than the ones here.' 


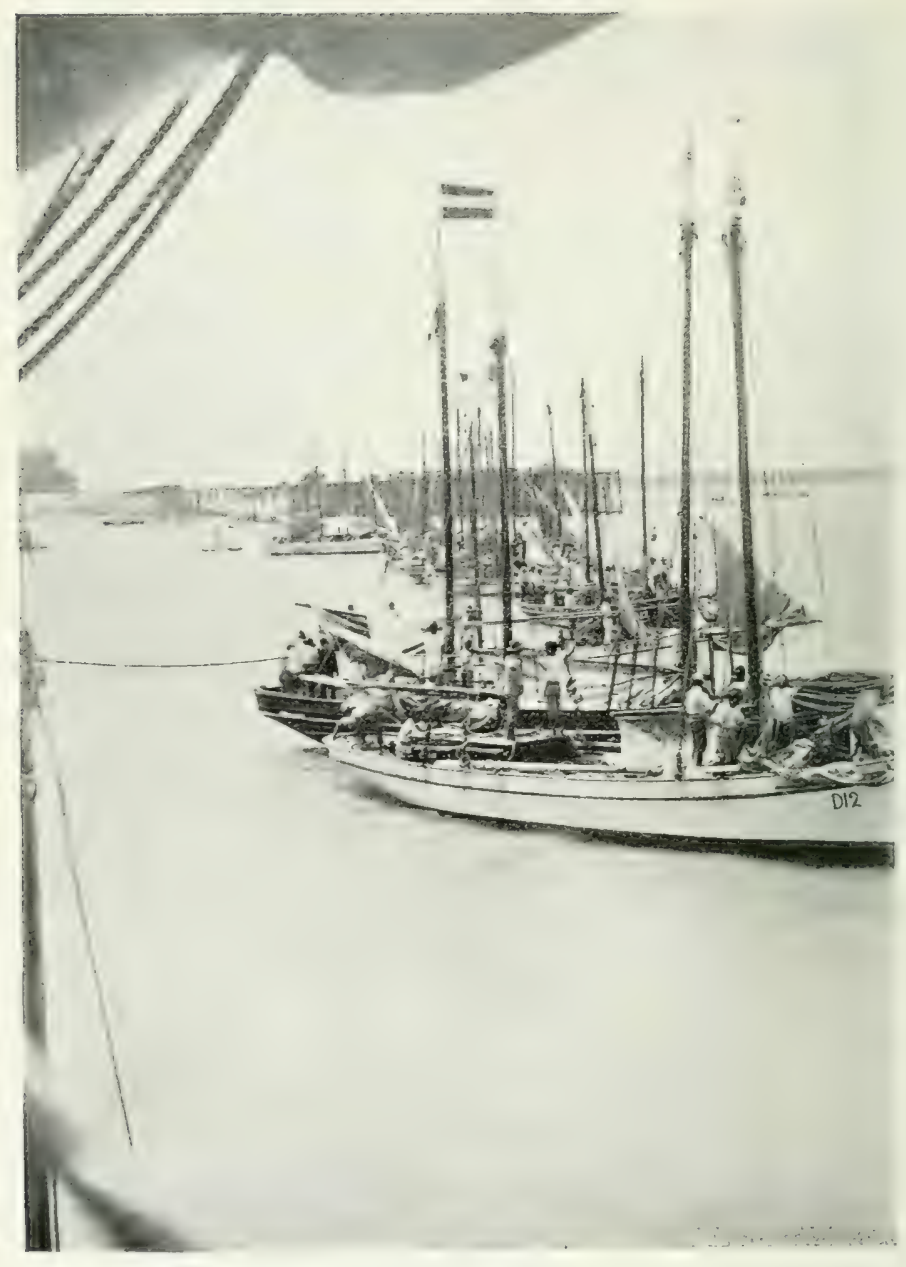

PEARIING I.UGGERS.

H. IV. Christie. 


\title{
CHAPTER XX
}

\author{
PEARLING AND DIVING
}

FOR many years it was known that pearl-shell existed in the waters of Port Darwin and the adjacent coast. No success attended the efforts made to locate a payable bed until IS84, when Lieutenant Chippendale arrived at Port Darwin in the schooner Sree Pas Sair with a crew of sixty men. His men were swimming divers, so he started work on the west side of the harbour in suitable water. Luck attended his efforts, for he struck a rich patch of shell. The news soon reached Thursday Island, the consequence being that there was a great rush of boats, upwards of one hundred reporting at Port Darwin. Some few of the boats were fitted out for prospecting purposes, but no luck attended their efforts, and I am certain the prospecting mostly consisted in tying the lugger up at a nigger's camp while the tucker lasted. Something like forty tons of shell were secured in the harbour, and that seemed to be the last of it. All the boats left, the majority never having even put their gear together.

Amongst the crowd which came to Port Darwin were several white divers, and I must say, from what I saw 
then and afterwards, I was convinced that for pearling the white men were not in it with the Japanese and Manilla men. The white men were not so amenable to discipline, and could not be depended upon like the coloured men. At times the white divers behaved outrageously. There was one man especially - a regular outlaw - whose sole idea was to paint the town red. As there was such a mixture of nationalities in the crews of the pearling boats, naturally there were some holy rows. I remember one Sunday evening a crowd of the pearling men, led by a great American negro, raided a shop in Chinatown, and proceeded to play havoc with the Celestial's goods. The police, in charge of Sergeant Waters-now Sub-Inspector and officer in charge of the Northern Territory police-appeared on the scene, and the raiders must have thought a bad squall had struck them, and before things could be made snug a lot of top hamper was damaged. During the fight Waters received a nasty cut over one of his eyes, which rendered him partially unconscious. Waters is a big, powerful man, which was a fortunate thing for him, for during the period I speak of strength meant a good deal. One day several man-o'-war's men, evidently having an idea that they had purchased the country, proceeded to take possession by having a jamborce in one of the public-houses, when Waters waltzed in. The sailor-men thought they would have some fun with the policemen, and so they did, for before the sergeant's fists they went down like ninepins.

On another occasion a Chinaman, who had terribly assaulted a countryman-anybody acquainted with the 


\section{PEARLING}

Chinese mode of fighting will understand what that means-when arrested threw himself on the ground and refused to move. I saw Waters calmly catch the prisoner by the scruff of the neck and walk away with him at arm's-length, the man's feet dragging on the ground.

For a few years two or threc locally owned boats did some desultory prospecting, but without any result of consequence. This went on until a Japanese diver appeared on the scene, and he struck good shell near Melville Island. Very soon a large fleet of pearlers were at work, and did well. Away from Melville Island and Port Darwin itself no shell of any consequence has as yet been discovered, but that it exists there is no doubt. In some places where there can be no question rich deposits of shell are, the depth of water prevents the work being carried out. I was sevcral times on the ground with the luggers, and opened many shells, for it was my ambition to find a pearl, but nary a one came my way. The first time I went out was on a large schooner, the tender of portion of the fleet. As soon as we anchored there was a great levee of men from the luggers to see the boss and get medicine. The complaints from which the men said they suffered were various, inside and outside, and all over their bodies. I noticed that the boss had a large bottle of some mixture, which he gave to one and all for inside use or outside application, the only variety being that an occasional man received a handful of sweet potatoes. Verily faith went a long way.

In connection with the same schoorier I had a very 


\section{IN AUSTRALIAN TROPICS}

unpleasant duty to perform. One evening the manager of the fleet was on board one of the through steamers having a jamboree with some of the officers. On returning to his vessel the manager took with him a large quantity of cigars. Getting wind of this, I had the schooner searched, and the cigars were found. I prosecuted the manager--who was a great friend of mineand he had to pay a stiff fine, besides losing his cigars. For many months the poor old fellow took not the slightest notice of me. One day seeing the fleet coming into the harbour from the grounds, I thought I would try an experiment. It was an ideal day for the purpose, one of those hot, sweltering, steamy days only experienced close to the line. I walked down to the landingstage and waited. In a short time my old pal landed and passed me with a charming scowl on his really grand face, but never a word did he utter. When he had passed me, I said, 'Say, C_—, don't be a _ — How about a cold whisky and soda?' I am not certain which invitation appealed to him and broke down the barrier, but we shook hands, irrigated, and were the best of friends again. The old chap has crossed over into the great beyond.

Pearl-shell only being found on a live bottom, it is morally certain that fish frequent the same ground. lieing in one of the boats one day, I determined to have a try. So, as soon as the diver sent up some shell I opened them and took out the oyster for bait. In a short time I felt a violent tug at the line, and fully believed I had hooked a tremendous fish. After being 


\section{CRAYFISH}

played for some time, the fish, as I thought, evidently got clear. Upon hauling in the line, I found that the hook was straightened right out. That, of course, convinced me in the belief that it was a fish. Soon after the diver, a Japanese, came on board again. I was telling him how I lost my big fish, when he grinned. It had been the diver all the time. It was he who straightened out the hook. Fancy a man playing 'the giddy ox' like that in thirteen fathoms of water.

The divers in their peregrinations often come across fine crayfish hidden in clefts of the rocks or in the coral. These crayfish are a great delicacy when on board the luggers, but the trouble is to get them there. If the diver is prepared to take the risk of trying to send one aloft, it simply resolves itself into a matter of speed. The diver may look round and be certain that there is no shark in sight, but as sure as he lifts the crayfish, one or more of these monsters of the deep will flash down and try to secure it. Crayfish is a favourite food with the shark; but although they may sight it and smell it, the trouble is for them to get at it in the rocks and coral.

Although considerable diving was done in the harbour of Port Darwin, it was not a favourite place, the bottom being so uneven and full of many holes. It was no uncommon occurrence for a diver to be calmly walking along conducting his search for shell, and then to drop right down several fathoms. Such a sudden descent generally meant paralysis to the diver. Then again there was the danger of carrying away the life-line or air-tube, 
or perchance of getting them foul of boulders, coral, or marine growth. To realise what such an accident means, one has only to fancy himself tumbling off a wall, or over a cliff forty or fifty feet in height, and then think of a similar incident under water. I often wished that I could have used the dress, so as to see for myself the marvellous sights of the deep-wonderful and varied marine weeds and forests, the beautiful shells and corals, and the marine monsters swimming about amidst them all. Especially in the great holes, and on the sides of the submerged cliffs, must the scenery be lovely. Many an hour have I spent on a still, calm morning, 'when the tide was low' gazing from a drifting boat down on to the ever-changing transformation scenes below. Judging from what I saw on the reefs, the sights in the decper water must be really magnificent. The divers often brought up a marine growth to all appearance like a miniature tree which had shed its leaves. It was perfectly black, and smooth. By cxposing the growth to heat, or steeping it in boiling water, it could be twisted and worked into any required shape. The Malay crews on the pearling boats were very fond of making bracelets from this material. The risks and dangers which the divers are subjected to are well known. An unfortunate diver recently lost his life in a peculiar way on the pearling ground at Aru Islands. He was at work below when the connecting life-line was suddenly wrenched from the hands of the tender with great violence. $\Lambda$ rroment later the air-pipe also parted under the strain, and the diver was a duomed man. 
The catastrophe is supposed to have been due to the playful gambols of a large 'diamond' fish which had been noticed near the boat; but the fact that in a subsequent search by other divers a portion of the divingdress was found, but no trace of the man's body, would go to show that the attacking monster was more probably a shark or sea-serpent. The 'diamond' fish are not vicious, but are said to have a playful though dangerous weakness for grappling with any object seen in the water, with hool-like appliances at the extremity of their arms or fins. One of our local pearling boat owners states that while anchored in Popham Bay once, near Cape Don, one of these huge fish fastened on to his dinghy riding astern of the lugger, and dragged it beneath the water. 


\title{
CHAPTER XXI
}

\author{
WHITE ANTS
}

Like other tropical countries, we have white ants in the Northern Territory; and the pest, as in other countries, can be contended with. The great thing is to be constantly stirring the soil. The ants attack certain trees most voraciously. Trees at my quarters were being demolished by the insects, when a Javanese boy I had said, 'Must do all the same as they do in my country-stir up soil round the roots.' This he did, apparently with good results.

The white ants used to play some funny pranks: a few which came under my personal obscrvation I will relate. I have already mentioned what the pests did to the floor of the old Custom-house. The ants apparently had no respect for the law, for they played the same game with the floor of the Court-house. One day I was seated in a chair giving evidence in a smusgling case, when the back leg of my seat went through the floor. When I picked myself up several remarks were made not complimentary to white ants.

The wine imported by the Chinese merchants contained so much saccharine matter, that it was impossible to test 


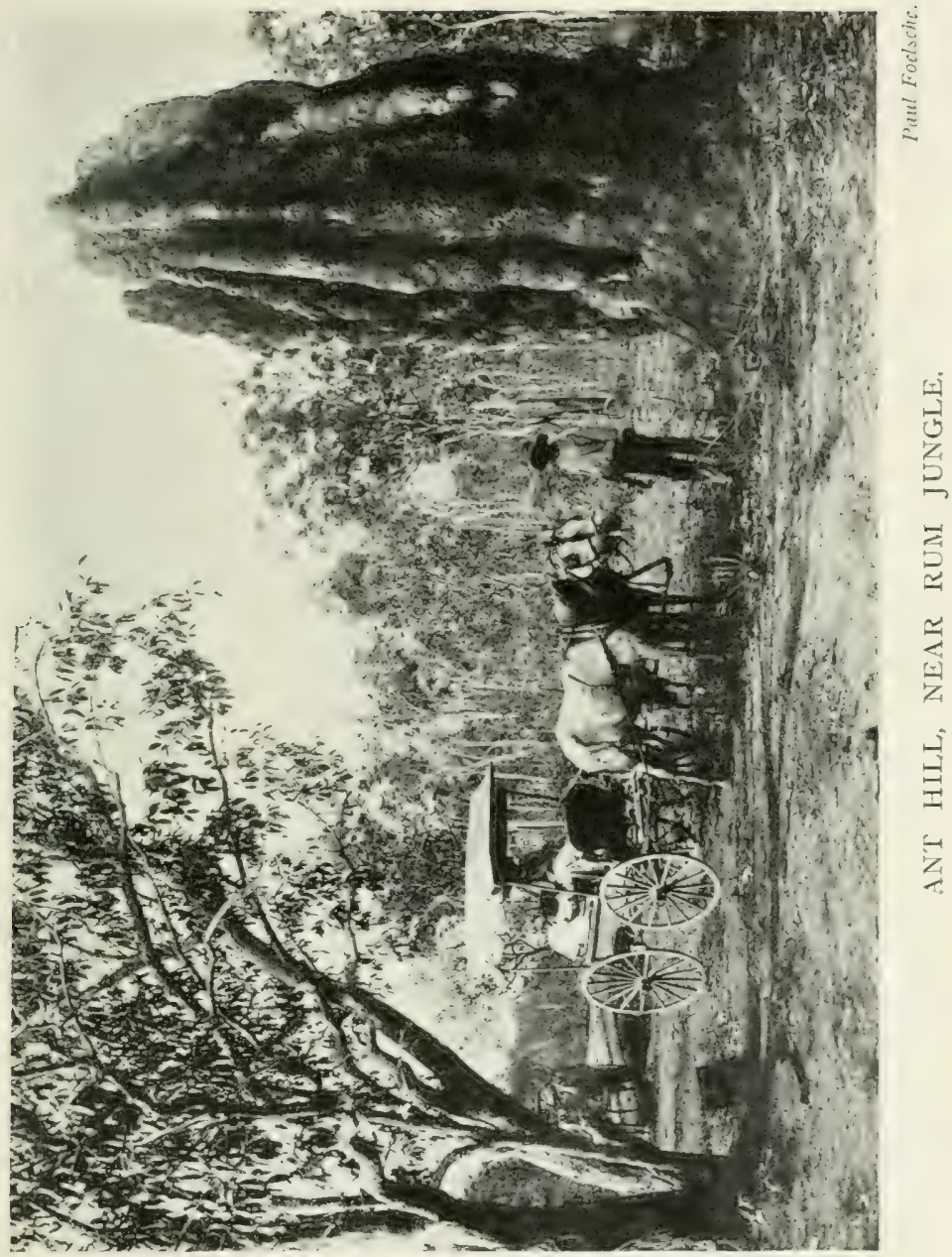



it with Sikes's hydrometer, so samples had to be put through the still. In spite of all my tests I could not make the wine contain a greater percentage of spirits than was allowed in wine, although I felt that such was the case, consequently only wine duty was collected. Inspector Foelsche, whom I have already mentioned as being a most enthusiastic and successful photographer, wanting some distilled water, asked me if I would put some through for him. This I did. The Inspector tested it and found it was not pure. Having been very careful in carrying out the distillation, I felt confident that something was wrong with the still. It was pulled to pieces, and we found that our friends the white ants had eaten through the lead-worm, so all the time water had been leaking into the pipe. The next Chinese wine imported had to pay duty as spirits, which was, at the time, double that on wine. So for some months the white ants had properly played into the hands of the Chinese importers. That these ants will eat sheet-lead is no traveller's story, but a cast-iron fact. I dare say that most people are aware that shcet-lead is rolled on a piece of soft timber, generally pine. Well, I have seen the whole roll, thirtytwo thicknesses, perforated by the ants, so that they could get at the timber in the centre. I have seen the spoke of a buggy wheel so eaten away that there was nothing left but a tube of paint and varnish. The same was the case with some of the wooden houses when neccssary precautions had not been taken to keep the pests out. I have seen a man go through the side of a weather-Luald house which to all appearance was sound, 


\section{IN AUSTRALIAN TROPICS}

but proved to be nothing but the shell of paint hanging to the uprights.

After a great opium robbery, which I will mention later on, I got permission to use one of the police-cells as a temporary bond for opium, but not being satisfied as to the stability of the back wall, I borrowed a hundred cases of whisky from one of the European merchants, and with these I built a solid wall at the back of the cell-inside, of course. When the new opium bond was ready the cell was given up. Imagine my disgust when we pulled the cases of whisky down to find that the white ants had eaten all the cases not exposed to the light, had devoured the labels and capsules, and were hard at work on the corks. In a few days they would have been at the liquor inside. Great Scott! it is hard to say what would have happened if the ants had struck the 'barley bree.' In consequence of the ravages of the white ants all the whisky was poured from the bottles into casks. To give a little information anent white ants, I do not think that I can do better than quote from an article written by my old chum, the late A. J. Gunn, on the subject: 'The white ant is much more widely distributed throughout Australia and tropical regions elsewhere than the baobabtrce, and may be found inhabiting fallen logs and decaying trees, or occupying wooden walls in Victoria, as well as residing in the spacious house of many mansions it erects fur itself in tropical Australia and Africa. The white ant, by the way, is not an ant at all, but a termite, and belongs to the order Neuroptera, which includes dragon-flies and lion ants (another misnomer), while the true ant belongs 
to the more extensive family of Hymenoptera, the most familiar types of which are wasps, bees, and ants. The term "white ant" is, however, quite good enough for popular usage, as scientific naturalists must have exercised a very nice discrimination in determining the difference between the species, the governmental system of a colony of termites and that of a hive of bees, or a nest of ants, being practically similar. A colony of white ants is divided into workers and soldiers, both sexless, but possessing rudimentary sexual organs; drones, males and females; and a queen-mother, as is the case with most varieties of bees and ants. The workers and soldicrs are reputed to be blind, but the former evince a remarkable perspicacity in discovering the whereabouts of a piece of edible wood, the natural aliment of the termite. Once found, it is wonderful what unanimity of purpose pervades a colony of termites that is bent on appropriating some cherished bit of property of man, or some tree or piece of wood that may hap to provide it with toothsome food. And it is marvellous what destruction can be wrought under the influence of that animating purpose in one night. White ants are children of darkness. They never voluntarily expose themselves to the light of day, or the assault of predacious birds and insects, for which their juicy bodies provide tasty titbits. All their work is done either under cover of night, through subterranean tunnels, or closed-in viaducts of their own construction. Their methods of subversion are as esoteric as those of a Nihilist organisation. Secretly, silently, insidiously, they invest the object they are in pursuit of with such skill 


\section{IN AUSTRALIAN TROPICS}

and address that its complete absorption is soon accomplished. Bags, boxes, books, boots even, left on the ground overnight, are, as often as not, found in the morning completely riddled with holes, or ramified with mud-cased tunnels. So speedy are they in their attacks on anything they wish to appropriate that northerners call after a messenger with a laggard reputation, to soothe, solace, and comfort him on his way- "Now, hurry up, or the white ants will be into you." In North Australia there are few native woods and less imported timbers that are impervious to the inroads of the termites, and houses, to be at all secure, have to be built on piles capped with galvanised iron or tin, and frequently, to make assurance doubly sure, and it is none too sure at that, piles are sawn in two and another plate inserted through the cut. Sheet-lead will not do, as the strong mandibles the white ants are provided with can gnaw through that comparatively soft material; zinc also is ineffectual, as they employ a natural acid to corrode holes in it. Paper-bark trees (a giant variety of titree) bloodwood (a eucalyptus), Leichardt, and another variety of pine-tree, are the only building timbers indigenous to North Australia which the white ants will not devour. Almost all fruit-trees, or trees producing commer al commodities, except the coffec plant, and indiarubbertrees, are liable to destruction from their attentions, and the arboriculturist or tropical planter of the future will have much difficulty in selecting plants that will not ruin their enterprise. At Springvale station, on the Katherine River, Northern Territory, Mr. A. St. John Giles suc- 
ceeded in raising an orchard in which custard apples, persimmons, mangoes, guavas, lemons, oranges, bananas, and pawpaws throve vigorously for some years, but gradually, one by one, the trees died, and all that was left alive in the end were the pawpaws and bananas. The white ants had entered and destroyed all the rest. But one of the most remarkable traits of the termite is that which is exercised in the construction of its peculiar hills. The hills are mostly built of a reddish-brown clay, to which are added small chips of grass and wood, and the whole fabric is cemented with the saliva of the termites In the long, dry months, when the sun burns with a steady, continuous heat, the masonry of the termites hardens to the consistency of bricks, and to other than human attack their castles are unassailable. The hills lend the landscape a novel and interesting aspect, particularly in such places as Fountain Head, Brock's Creek, and Burrundie, on the Palmerston and Pine Creek railway line, where, with a base not more than five feet in diameter, the structures are made to any height from ten to twenty feet. These hills are often surmounted by shapely minarets and slender spires, which add a few more feet to their stature, and some-not superfluouselegance to their appearance. Generally speaking, throughout the north the typical ant-hill is a rough, irregular mass of from two to ten feet high, and presents few readily distinguishable features; but in the Napicr, Broome Bay district, in the extreme north of Western Australia, the hills are not infrequently wider in the middle than at the base, and are built of a collection of 


\section{IN AUSTRALIAN TROPICS}

mushroom-shaped lumps that overlap each other and present the appearance of a collection of old-fashioned straw beehives piled on a central pedestal. In some parts of the Kimberley district, particularly on heavygrassed plains, hundreds of sharp-pointed little pinnacles, like large cones of loaf-sugar in shape and hardness, are clustered on every acre of land, and when the grass is at its tallest, gallops after runaway steers result in frequent falls to rider and ridden, from contact with the hidden stumbling-blocks. But the most peculiar of all houses which the curious little entomological mound-builder erects for itself are those which are called meridional ant-hills. These are not more than five or six feet high, about five or six feet long, and from two to three feet wide at the base. They taper sharply to the apex, and resemble a broad wedge. They almost invariably point along southsouth-east and north-north-west, and are probably so built to present the least surface resistance to the south-east and north-west monsoons. It is a moot-point why the white ant builds such goodly mansions for itself, and bush naturalists incline to the theory that the mound is first raised round some tree stump or other object it may wish to convert into food, and this is possibly the correct reason, if a story that went the rounds of the north be true. A stockman, who had taken a Burketown mosquito net, was camped at the Stuck-up outside Pine Creek. He slept soundly until early morning, when he was aroused by the tickling of a million creeping things crawling over him. He tried to move his arm himself, but could not shift it. He tried to wriggle, but 


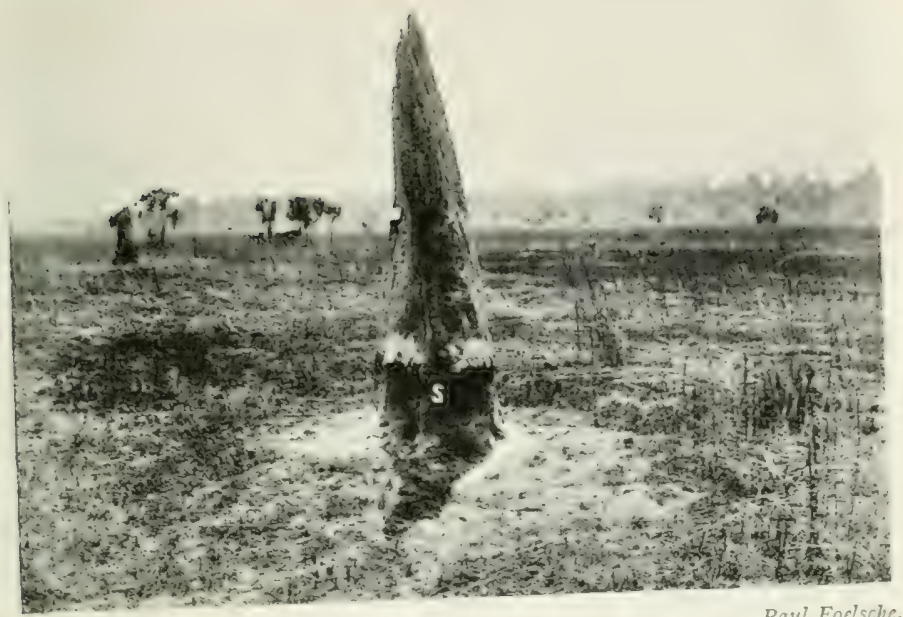

Paul Foclsche.

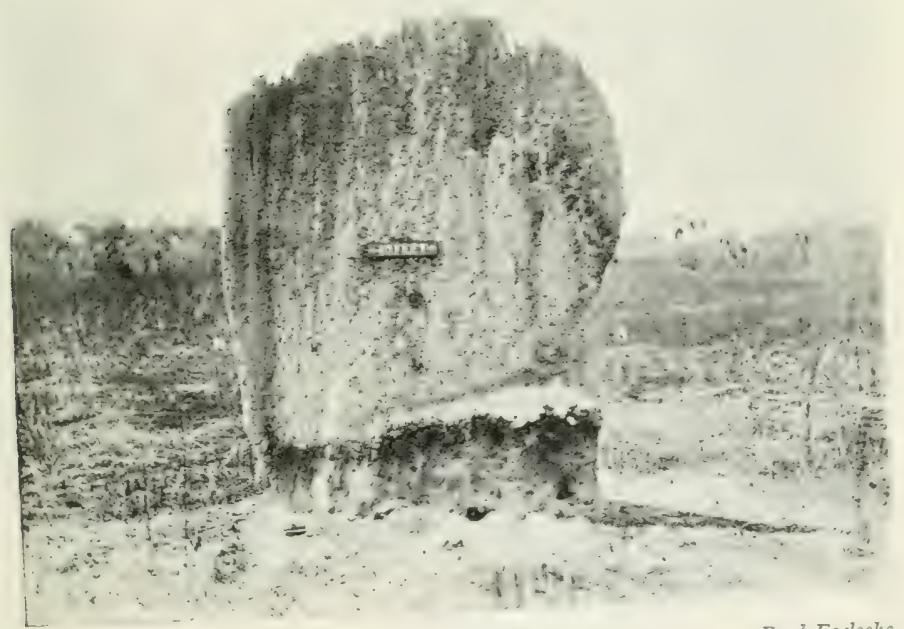

Paul Foclsche.

MERIDIONAL ANT HILL. 



\section{ANT-HILLS}

found he was held by firm, even pressure all round his body. His dawning consciousness revealed to him the fresh, unctuous odour of newly turned earth. His first definite impression was one of amazement. His next sensation was one of speechless fear. He thought he had somehow been mistaken for dead, and having been buried in a state of coma, was being prematurely converted into earthworms' food. A cold sweat broke out all over him. He made superhuman efforts to free himself from the mould, but made no impression on it. He thought his case hopeless, and did what any one else would have done in the situation-he yelled. He struggled some more. It was a useless expenditure of energy. He was getting suffocated, and he yelled again. His waking mates near by heard the muffled yells, and seeing nothing, wondered. More muffled yells, evidently of a mortal in agony, bestirred them to action. They looked about, and were surprised to find the yells came from an evident ant-hill. They knocked some lumps off it, and would have run away for fear of the discovery they made. They saw a human foot! Curiosity held them to the spot. The foot palpably kicked. They knocked some more off, and were astonished to find more parts of human anatomy. More earth was hastily cleared away, and they were more than ever surprised to find their mate Bill, who they thought they had left in the public-house at Pine Creek the night before, beneath the mound. Bill had fainted, but when he came to, his language was lurid and smelt of sulphur. He upbraided his mates with, "Why the dot, dash, asterisk did you 
blank, dash, blanky fools blank well blanky bury me like that?" Note of interrogation, hyphen, full stop. "I)id you blanky well think I was dead?" "We didn't bury you, you screaming idiot. Look! It's the white ants."

The other timbers mentioned by Mr. Gunn are in a measure white ant proof, but the Northern Territory Cypress Pine is the only wood which can be relied on to resist the attacks of the pest. In Queensland there is a Cypress Pine, a quick-growing variety, but experience has proved that it cannot withstand the Northern Territory white ants. The Cypress Pine in our Territory in its natural state is found in a hungry, sandy, gravelly soil, and is very slow growing. Dr. Maurice Holtze, Ph.D., F.L.S., Curator of the Adelaide Botanic Garden, who was for many ycars in the Northern Territory, is of opinion that the Queensland Pine is a different variety from that growing in the Territory. The scientific name of the Pine is Frencla robusta. Dr. Holtze considers that the Northern Territory Pine should be Frenela rolusta variety Inter Tropica. The late Baron von Muelicr agreed with him, but for scme reason the idea was not adopted 



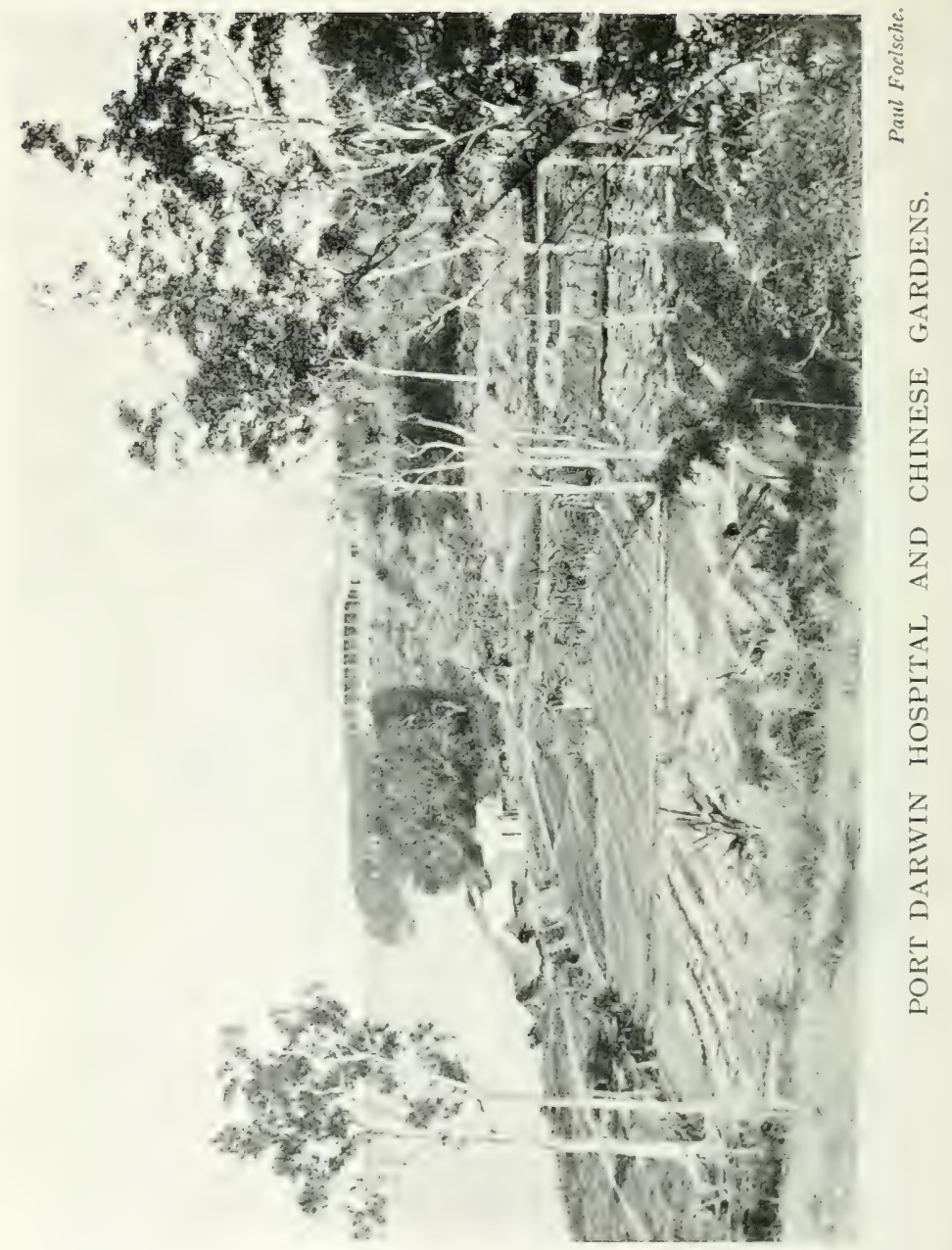




\section{CHAPTER XXII}

\section{ABOUT CHINESE AND OTHERS}

For the Chinamen gुenerally I have a wonderful admiration. People may cry out against them, but the conclusion I arrived at was that it was their virtues, not their vices, we had to fear. I found them as a rule industrious and persevering. The Chinamen are lawabiding subjects, provided that they are impressed with the fact that they must obey the law, and are not allowed to do as they like. Their ideas of living and sanitation do not coincide with ours, still Celestials can be convinced that the white man is not a No. I fool. Drastic measures bring them up with a round turn.

The characteristics of the Chinaman, as I have observed them, are splendidly described in the following words, which I read somewhere once, 'Cruel, yet kind; generous, yet miserly; clever, yet stupid; energetic, yet stolid; honest, yet cunning:'

Many years ago there was a bad outbreak of smallpox in Chinatown in Port Darwin. There was trouble in getting some of the Chinese to move out of the miserable hovels in which smallpox was known to have 


\section{IN AUSTRALIAN TROPICS}

existed. The Acting Government Resident soon settled the difficulty by ordering the police to set fire to the humpys. This was done, and some twenty-six of them were destroyed. The occupiers tried hard to save some of their household goods, but as fast as they dragged them out of the burning huts the police threw them back again. At that time, as I have already mentioned, sanitation laws were not enforced, and pigs were kept by Chinese in their dwellings. Naturally the fire caused the animals to make themselves scarce. Having witnessed the destruction of the huts I returned to my quarters, which were close to Chinatown, and found one of the homeless pigs asleep under the verandah. It had to seek fresh fields and pastures new.

During the construction of the Pine Creek Railway, Chinese in great numbers arrived from Hong-kong, the largest batch - about three hundred-coming in the China Navigation steamer Taiyuan. An experience arising out of the advent of this lot I shall long remember. It was the day of our annual races, which were held at Fannic Bay, about four miles from Darwin. I attended the races, leaving the officer next in command in charge. During my absence the steamer arrived, and for some reason which cannot be assigned, the officer went stark mad. Before it was discovered, he had insisted on half the Chinese passengers being transhipped to a small lighter. No provision had been made for their landing, therefore for many hours they were detained on the lighter, and were without food and water. Naturally they resented this, and some ugly talk was 


\section{CHINESE}

indulged in, and nasty threats made, so the interpreter said. It was well on in the evening before arrangements could be made for landing the Celestials. It was a lovely night, with a glorious moon. Expecting trouble, each of us officers carried a revolver, and as an additional security the late Mr. C. G. Miller, whose yacht Red Gauntlet was in harbour at the time, ordered the crew ashore to assist. They were in uniform, each man carrying a Winchester carbine. The lighter was hauled alongside the jetty, and the work of landing and searching was carried out without further trouble for the line of bluejackets and the glistening weapons completely calmed the indignant Chinese. Soon afterwards one of my officers developed smallpox, contracted, it is presumed, during the searching. He recovered, but was very much disfigured. Subsequently all Chinese arriving from Hong-kong were quarantined. At one time we had between three and four hundred Celestials in lighters at the quarantine station. On one of the vessels one day a man was found who was supposed to have developed the dread disease. His companions. knowing that if such was the case it meant a longer detention. took the matter into their own hands. No report was made to the medical officer. The men first threw overboard a plank, and then the man who was supposed to have the disease followed. With the aid of the plank the unfortunate fellow managed to reach the shore, where he was found a fortnight afterwards amongst the mangroves quite well. It was a free and-easy business. Another Chinaman jumped overboard from the lighter on which 


\section{IN AUSTRALIAN TROPICS}

he was confined, and swam to another on which his wife was.

Naturally during my long sojourn in Port Darwin, in the position I occupied I had constant dealings with the merchants, and I say straight out that you would not find a better and more straightforward lot of business men anywhere. My experience was that a Chinese merchant's word was his bond. To give you an idea how the Chinese merchants viewed the Customs, I have a cable in my possession from a merchant in Hong-kong notifying that he had omitted to invoice, in some cargo sent down, two shillings' worth of washing stuff (towels). Now you can't cable for nothing, but the Chinese merchants had realised that they had to toe the mark as far as the Customs were concerned.

My friends in Darwin always said that in time I should develop a pig-tail owing to my admiration for the Celestial.

Of the hospitality of the Chinese there can be no question, judging from what I found both in Darwin and up-country, that is, on the goldfields. The best the Celestials had was always produced, especially liquids, with which they invariably seemed well provided. In fact, they apparently considered it only fit and proper thiat Europeans should imbibe, and I guess it was not difficult to find some always ready, and with great calpacities. I found the Chinese most abstemious; in fact, during my fourteen years in Port Darwin I never saw one the worse for liquor - I mean, incapable of taking care of himsli. I remember on one occasion 


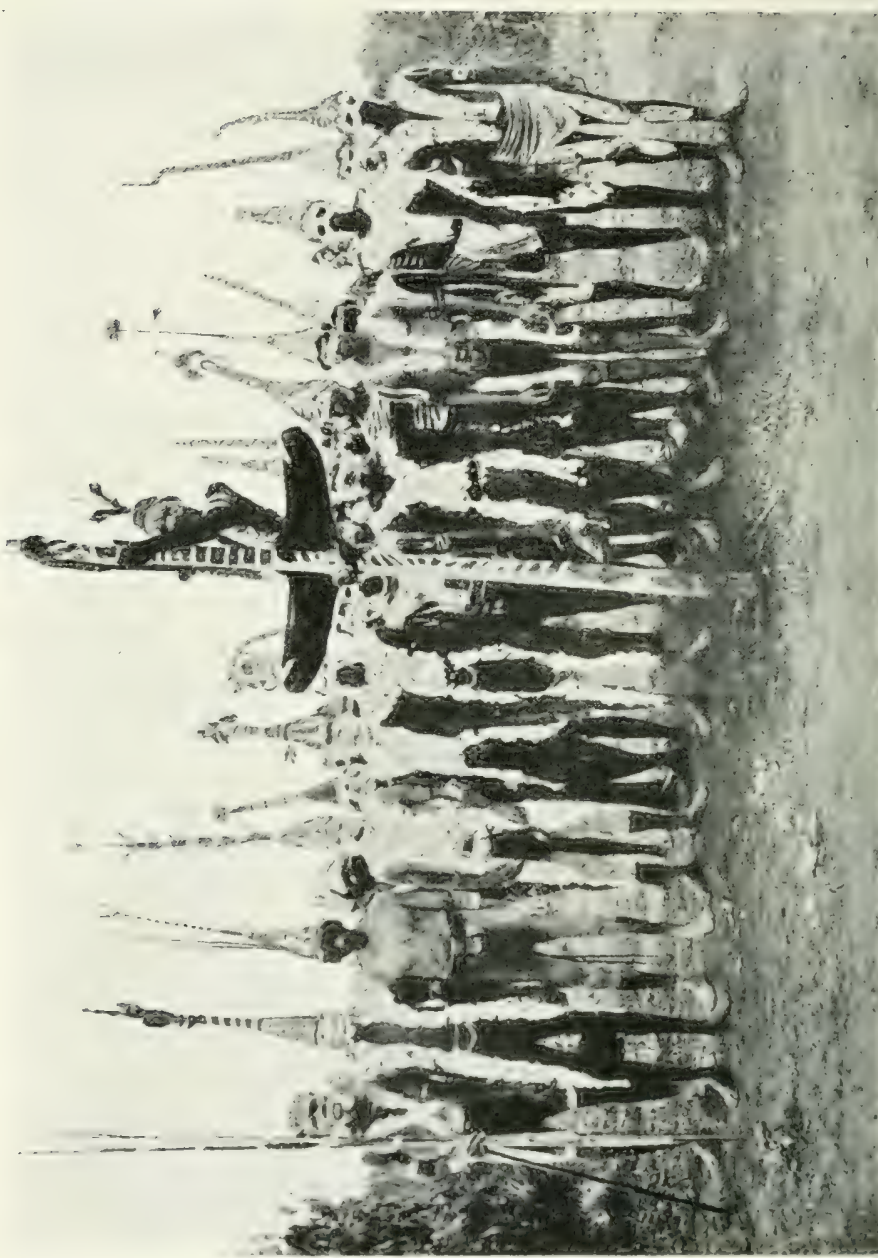


I was up-country with the Resident, when we brought up at a mining-camp. The first words were, 'Would you like some stout?' No, we did not care about stout, but we had a drop of square face. 'Would you like something to eat?' 'Oh yes.' We heard a chasing and a deuce of a noise among the fowls, and in half an hour we were doing our best to get outside two of them. The birds were not bad considering they had only been dead so short a time. Talking about Chinese hospitality reminds me of a yarn a friend of mine, who was on the goldfields in the early days, told me. He was in his hut one day when a nigger came in, and seeing a ham hanging up, inspected and smelt it. 'My word, all same Chinaman,' was his verdict.

With few exceptions the Chinese in the Territory dressed in their national costumes and likewise carried out their national customs. During the New Year all business was suspended, and the usual processions were indulged in, with the customary dragons and the paraphernalia associated with Chin Chin Joss. The firing of crackers was simply enormous. They were eternally Chin Chinning Joss. This was particularly the case at New Year time, and when some big Chinaman from the goldfields visited the town.

I was much disappointed with the Chinese idea of music. At one time they used to keep up the infernal din nearly all night long. However, as the European residents found that a little sleep was desirable, the pandemonium was put a stop to. Give me a nigger corroboree before a Chinese band. The singing of the 


\section{IN AUSTRALIAN TROPICS}

niggers, the clapping of hands on thighs, accompanied by the booming noise of the bamboos were, if somewhat weird, certainly melodious in comparison to the strains of the Chinese band.

The instrument which makes the booming noise is a pipe made of bamboo, about five feet long, all the joints of which are burnt out with a firestick. The niggers blow into the bamboo, and cause a sound like a deep growl, broken up at regular intervals by a distinct booming.

The Chinese had their theatre also. It was an openair affair, but no seats were provided. It was a funny sight to see the audience crowding to the house of amusement, carrying every variety of seat with them. The play, which extended over a fortnight, was carried on until the small hours of the morning. The part I used to enjoy was watching the calm manner in which the stage hands carried out their work. They would attend to the lights, and make any necessary alterations on the stage while the performance was in progress, walking amongst the actors as if they (the attendants) were invisible,

The first Joss-house erected in Darwin did not please Joss. It faced the wrong way. At any rate it was the opinion of those who were supposed to be able to interpret the god's ideas. So the whole concern was pulled down, and re-erected facing another way. This little fad of Joss's cost the worshippers between seven and eight hundred pounds.

Mining being one of our principal industries, the bulk of the Chinese were either interested in some of the 


\section{CHINESE}

mines, or engaged in the work of development. These men were very observant, and generally knew what was going on. I remember one of the Chinese merchants, Yet Loong by name, being in the Custom-house one day when the Pine Creek mines were spoken of. The principal mine was being worked by an English com. pany. Yet Loong said, 'Say, Mr. Sears (he could not pronounce Searcy), what for that man along Pline Cleek fool-what for him spend forty thousand pounds topside? more better spend him along bottomside first time.' The Celestial just struck the keynote of so many failures caused by companies spending money on the surface instead of putting the capital into the shafts to properly test the mine.

There was another Chinese merchant named Yam Yan, who would never answer a question without giving it consideration. To do this he always fired off several immense yawns. He tried to cover his mouth with his hand, but at times it was hardly possible.

The Courts were not much resorted to by Chinese in connection with disputes amongst themselves. I believe they had a sort of self-constituted tribunal which settled most of the troubles.

Amongst our Chinese we had many representatives of river pirates and other ruffians.

I had some funny experiences with the Chinese in carrying out my duties of a Customs officer. When, in I880, Port Darwin finally ceased to be a free port and duties were imposed on certain imports, an export duty of five shillings per ounce was placed on gold. 


\section{IN AUSTRALIAN TROPICS}

This was afterwards reduced to two shillings and sixpence, then one shilling per ounce, and was eventually abolished, but the law still necessitated the reporting at the Custom-house, for statistical purposes, of all gold for export. As can be imagined, many people, both white and yellow, objected to pay this duty, and did their best to evade it. Every care was taken to prevent this abuse. Chinese passengers and their luggage were thoroughly searched as a rule, and the Europeans' word was taken unless there was a suspicion that they had gold for illegal shipment. As a rule, the latter did not carry gold with them. I think here I had better relate the fate of an Irishman, who is supposed to have smuggled out about seventy ounces. I do not think that there is any doubt that he had it with him from what I heard after he sailed. This man had a great fancy for turning somersaults, which amusement he constantly indulged in. One morning he was missing, it being presumed that he had been turning somersaults, when he did one overboard. His gold was not found, which is not to be wondered at, as he would be fairly certain to have had it round his waist. In carrying out our duties, searching for gold, we had some peculiar and unpleasant experiences. It is well known that it is part of the religion of the Chinaman that if he dies abroad, his bones shall be returned to the Flowery Land, and where the defunct had friends this was done when possible. The remains were generally packed in cases and shipped as cargo, but I have often found skeletons in the passengers' luggage. It was no nice work over- 
hauling skeletons, but I have had as many as twenty at one time laid out on the Custom-house floor. We never succeeded in finding gold concealed in the bones, however. Gold being so compact, it is not a difficult matter to conceal it. Considering the quantity of gold the Chinese going to Hong-kong took with them, it is surprising that trouble did not arise on board the steamers, but I never heard of a case. I have known a Chinaman leave with three hundred and fifty ounces round his waist-rather a temptation. As I have said, the duty was finally abolished, but word to this effect did not reach me from Adelaide until three days afterwards. During that time I collected $£ I I 2$ duty from the banks. When buying gold the banks collected duty from their customers, so they had no claim to it, and the original owners not turning up, the revenue benefited, but they would have had a rtal hard time proving their claims even if they had presented themselves.

Perhaps the Chinese are no worse than others, but judging from experience, their ways at least are cunning and peculiar. On one occasion a steamer from Hong. kong arrived just before dusk, and there being some ninety Chinese passengers to land, we determined to search them as they went over the side. During the investigation we discovered and secured six men with opium concealed in a most extraordinary manner on their persons. There was another on whom we found opium, but before we could secure him or his goods he rushed down the gangway into the boat alongside, which was crowded with his countrymen, for the passengers 


\section{IN AUSTRALIAN TROPICS}

had to be boated ashore. It was dusk, and all the Chinamen being so similar in appearance, we could not identify our man, so the whole ninety Celestials were rushed into the Customs shed and the doors locked. Having secured lanterns, my landing-waiter (W. G. Stretton) and I went through the lot again. It was a sweltering evening, and the heat and smell were very thick, as can be imagined, but we secured the offender, at any rate we discovered one with opium, and he and his chums eventually found what a salubrious retreat Fanny Bay Gaol was. On another occasion, chancing to look over the side of the steamer while the Chinamen were being passed into the boats, I spotted a man who had opened a trunk and was serving out new clothing to the other occupants of the boat. These, in their turn, were slipping on the new silk suits over the clothes they already wore. I let the game proceed until we reached the shore, when the law-brcakers were all run into the shed and relieved of their extra clothing, which was confiscated. The owner gained experience, and the Government the clothes.

One day I found a man trying on a similar game, but it was tobacco this time. He served out to each man two packets, nearly one pound in weight, of Chinese tobacco. When ashore I collected some seventy pounds. False bottoms in trunks and packing-cases was another dodge tried, and I dare say at times may have succeeded, but I had the satisfaction of bowling out several of the men, anc on one occasion a considerable amount of opium was confiscated. Ilaving received word that a quantity of 


\section{SMUGGLING}

opium was to be run, I had men stationed at various spots on the beach. We did not get any opium, but we had another experience in the way of an attempt to do the Customs. One of the officers stopped two men who had landed from a steamer, one of whom was carrying a coop of fowls. The other fellow was stuffed full of cigars. He had on two pairs of trousers, the inner pair being tied at the bottoms, consequently the cigars could not get adrift. The man with the fowls had no contraband on his person, but in the coop two boxes of cigars were discovered. The fun of the thing was that the man with the fowls was cook to the Judge and Acting Resident.

I remember one night one of the tide-waiters rushed at a Chinaman whom he thought was smuggling, and caught hold of his coat, but the man inside slipped out of it and jumped over the jetty, just twenty feet, into a little over two feet of water and a rocky bottom at that. He escaped. The coat was well lined with opium. Passenger steamers not being allowed to convey gunpowder, the Chinese from Hong-kong, travelling in them, took to carrying it in their luggage. I have found as much as forty pounds in a man's trunk. Two or three prosecutions soon put a set on that unlawful business. It came to our notice that the Chinese were carrying on a post-office of their own, great numbers of letters being brought down by the passengers for delivery to their countrymen in the Territory. This, evidently, had been going on for years, and the consequent loss to the department must have been considerable. After it was 


\section{IN AUSTRALIAN TROPICS}

discovered, all letters subsequently found in the Chinese luggage were sent to the post-office, and the Celestials had to fight it out there. I should not be surprised if in some cases they do not run their own post-office to-day, for what a Chinaman doesn't know, if he lays himself out for it, is not worth knowing.

I once had a trip up-country on duty. It was in connection with a robbery of opium from the Customs bond in Port Darwin. I had about a fortnight's riding over the goldfields. I visited every Chinese store, and counted and sealed the tins of opium in the possession of the storekeepers; for, from information I had gained before leaving Darwin, I knew fairly well what each man ought to have. The idea was that if unsealed tins were offered for sale the presumption would be that they were either part of the loot or were smuggled. Some one, presumably Chinese, had broken into the Customs bond in the railway yard, forced open the large iron chest in which the opium was stored, and taken four cases. Not a sound had been heard, although four or five massive Chubb locks had been broken open. In the bond we had a small ship's magazine, the appearance of which I expect led the robbers to imagine it contained something valuable, for that was taken also. It was afterwards found in the mangroves close to the bond. It had been forced open, but the contents, a few explosives, had not appealed to the thicves, for we found these also. We never recovered any of the stolen opium, in spite of the strict watch which was kept and the searching high and low. 


\section{PERMITS}

Some suspicion was arouscd in connection with the Chinese sampans trading on the coast, so one night I went outside the Heads in the steam-launch, drifting out with the last of the ebb-tide, and lay off there at night. At daybreak we sighted a big sampan running out before a strong south-easter. The tide had turned again, and she had a strong $\mathrm{ebb}$ in her favour. We immediately gave chase, the launch going for all she was worth. Not the least notice was taken of us until we got fairly close, which we did after a bit of a struggle. The sampan then hove to, but as she did so we saw a case go over the side. Having great way on, it was some time before we could make a search, which was done without any satisfactory result, the case, of course, having disappeared. The incident was most suspicious, and I have little doubt that the case which was thrown overboard was part of the spoil. If it were the opium, it must have made the crew very sick to have to get rid of it in the way they did. Of course we did not find anything in the sampan.

When Port Darwin was virtually closed against further Chinese immigration, and those already resident in the Territory wished to visit their native land, permits were issued so that the holder could return. The permit contained a full description of the man to whom it was issued. Anybody acquainted with Chinese can understand what that means. We found that the permits were being sold in Hong-kong, and men who had never been in our country were entering under them. A fair number managed to get in, but several had the satis- 


\section{IN AUSTRALIAN TROPICS}

faction of seeing our lovely harbour and then having to return straight back to Hong-kong. The permits were then issued in duplicate, each one having a photograph of the man to whom issued pasted on it. Even then there was trading in permits, the photograph of the absentee's copy being substituted for one of the man who bought it. The purchasers evidently were not aware of the duplicate in the Custom-house at Port Darwin. We used to take these on board the steamer, so as to see that there had not been any funny business with the photographs. Several of the Chinese had to return to the Flowery Land wiser and sadder men. However, before I started taking the duplicates on board, one man got to windward of me beautifully. The picture on the permit he handed to me was a perfect likeness, and the other particulars seemed all right. He must have been a cool customer, judging from the calm and indifferent manner in which he treated the whole examination. I discovered the fraud as soon as I got ashore; but by the time I returned to the steamer he had disappeared, and that was the last we saw of him.

Before a steamer left the harbour the officers of the ship and agents always conducted a close search for stowaways. Many Chinese tried the game, and when discovered I am afraid the treatment they received was not kind. Numbers of Europeans were bowled out in endeavouring to get a cheap trip. I have seen over and over again, when the boat covers were removed, numbers of white men hiding in the boats. Men have been found trying to palm themselves off as a quarter of beef by 


\section{STOWAWAYS}

hanging to one of the meat-hooks covered in a linen bag. I remember a lot of miners endeavouring to work off the swindle, but the officials won by a nose. The men had concealed themselves under a lot of mat dunnage on top of the cargo-rice. One of them had an awful nose, an exaggerated Wellington. The agent was fooling around, when he stood on the feature in question. It was too much, the nose had to come out; that was fatal to the other noses, and those who wore them.

I received many letters from different Chinese, which were, as a rule, very funny. Some I have in my possession now. I will give a couple as instances:-

'Mr. Custom-house, Esq.,-My son send me a small bottle medicine wine for curable my foot.'

'Mr. Searcy, Esq.-Sirs,-Captain William he come this afternoon, his said into me, he fin out a gin case, in room and contain same in fan and handkerchief. And his send to-morrow morning in to me so you please charge same, the invoice amount £I8. I will tell Mr. Adcock in the invoice.'

Besides being very hospitable, I have always found the Chinese merchants ready and willing to pay for any scrvice rendered. I remember one instance in particular. A steamer had discharged her cargo of Chinese goods into a lighter, when all at once the lighter sprang a leak, and before anything could be done, down she went in thirteen fathoms. I was close to the craft when it happened. The tide was running out very fast at the time, and the next thing we saw was the whole of the deck cargo drifting out to sea at the rate of 


\section{IN AUSTRALIAN TROPICS}

several knots. A good portion was collected by boats. The most valuable of the cargo, including several cases of opium, was below, and in consequence was lost. Before the Chinese could recover the insurance, it was necessary for them to produce a certificate that the cargo had been lost. The Customs Department had the only account of the goods in the lighter, so application was made to me. I offered the certificates to the Chinese, but they one and all refused to take them unless they paid for them. I agreed, and I am glad to say that on my certificates the insurance money was paid.

As an evidence of what perseverance will do, I should like to relate a little instance that occurred at Port Darwin. A white man was sent to prison for several years for stealing gold. During the time he was incarcerated he thoroughly mastered the Chinese language, being able to speak, read, and write it fluently by the time he was released. Subsequently, when some important works were being carried out, the man returned to Port Darwin under another name as a boss, and a most useful man he proved, for many Chinese were engaged on the works.

Naturally, when the Chinese sought the aid of the Court, some very amusing things occurred. One day some Chinese witnesses were to give evidence, but the necessary roosters for the purpose of administering the oath-the fowls have to have their heads cut off-were not forthcoming. The Court was adjourned so that the birds could be procured. On reassembling, the poultry 


\section{HORSE-PLAY}

were there, and all things necessary fixed up. When the magistrate returned to his quarters he discovered that the Chinese had helped themselves to his fowls. These were the ones used in Court.

There was a European merchant in Port Darwin who boasted that he gave one-seventh of his takings to the poor. One day he was speaking of the amounts he gave away, when a rough diamond, who was engaged on one of the launches, and who overheard the boasting, interjected, 'Yes, W— places all his bad debts to the credit of the Lord, and lets the poor fellow collect them himself.' Many a true word is spoken in jest.

As in similar places, a good deal of horse-play was indulged in at Port Darwin. I will relate one instance, and how it came home to one of the men indulging in it. The landlord of one of the hotels answered the call of several young fellows, who were ready for any devilment. The landlord was wearing a beautiful white silk shirt. In a moment it was in ribbons. Not a word said the landlord. He retired, and soon appeared with a similar shirt. This was also destroyed. Again he returned with yet another silk shirt, which met the same fate as the other two. The landlord then turned to the ringleader and said, 'Go on, old chap, they are all yours.' And so they were; the man had actually been destroying his own shirts.

I have spoken about the niggers' love of strong drink. I will relate a little incident in connection with that love which cost me some expensive grog, and at the same time proved that the black man likes something that 


\section{IN AUSTRALIAN TROPICS}

will 'bite.' One Sunday evening the niggers cleaned out my storeroom for me, that is, commandeered all my grog and wine. The thieves and their friends had a glorious time that night at my expense. For a time they made night hideous. The police at last appeared on the scene, and put a damper on the spree. When before the magistrate next day, one nigger who had participated in the drinking was giving evidence, a bottle labelled 'Seppelt's Blanquette' was held up, and he was asked if he had tried it. He answered, 'Oh yes; no good, all same water.' Now Blanquette is a very choice light wine. When his attention was directed to the spirit and liqueur bottles his eyes sparkled, and he said, 'My word, good fellow.'

As the niggers take most kindly to all the white man's vices, naturally they are great smokers, and commence very young. I have seen the youngsters drop the breast, take the lighted pipe from the mother's mouth, and proceed to blow a cloud on their own account. Niggers like strong tobacco. I had a chum in Port Darwin, a methodical sort of a cuss, who always cleaned his pipe into a box. When the box was full of 'dods' he would pass it over to me for my old flame, 'Flash Poll.' The aroma from the 'dods' was nearly enough to knock down a decent wall, but 'Poll' simply revelled in it.

I have already mentioned how the blacks gorge when a good opportunity arises and the necessary fixings are handy. So do the little niggers.

We had in Port Darwin a firm of merchants, one 



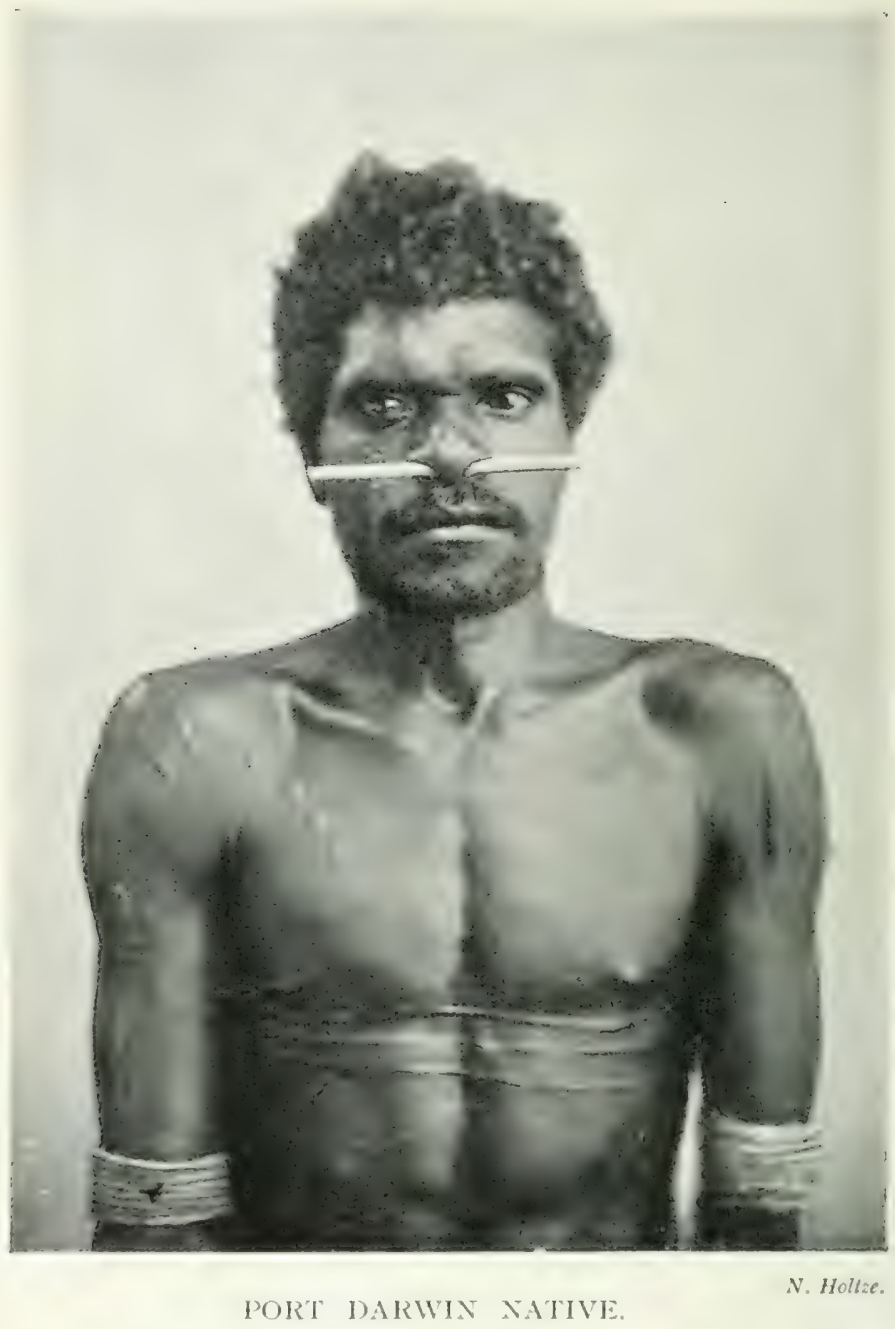




\section{BLACK NIPPERS}

of the members being known as George. Now George was literally worshipped by all the niggers, old and young, for he treated them well, and they did faithful work for him. At stated intervals George used to run in a crowd of young niggers of both sexes, and supply them with as much tucker as it was possible to take in during one sitting. It was a revelation the quantity the little black cusses could put away. Their 'capacities' would gradually distend until they had the appearance of the proverbial pup whose end is generally put down to water. At last the cry would be, 'Enough,' for the little niggers were happy and tight without the vestige of an appetite.

The youngsters as a rule were lively, cheerful, mischievous little devils, and great mimics. Cricket was a favourite game with them, and it always seemed to me that there was infinitely more fun in watching a crowd of these black nippers at the game-their paraphernalia simply consisting of two sticks, a couple of rusty kerosene tins, and a ball of rags-than in viewing the biggest cricket-match ever played.

I am afraid that we used to annoy the good Jesuit Fathers by encouraging the young black beggars to sing us portions of the service which the Jesuit Fathers had taught them to do in the vernacular. Sweet singing it was, too. 'Tickpence' did the deed. 'Teepenny' might call forth a slight response, but our Port Darwin black youngsters had souls above coppers. They liked white money.

The bucks, when in town, invariably carried with them 


\section{IN AUSTRALIAN TROPICS}

straight sticks, about three feet in length, with which to amuse themselves whilst walking along, the game being when a nice piece of sward, or tuft of springy grass or bush for preference, was spotted, to rush at it and with a 'whough' dash the stick down with great force perfectly flat out, with a slanting tendency, so as to make it ricochet. An expert at the game would produce some splendid flights. An extra good display was always loudly applauded, the chap who did it being as enthusiastic in the cheers as any one.

When on the move the youngsters carried on the game, and the incessant 'whoughs' would be accompanied either by derisive laughter at a failure or shrieks of delight at a successful flight.

Many of the black men are employed in the stores, and women in domestic duties at the houses of the residents. The women, as a rule, returned to their respective camps at evening, but before leaving had to shed their town skirts and simply walk off with their 'nargers' (waistcloths) on, the dress being left at their employers', to be shipped on their return to duty in the morning.

In a previous chapter I mentioned the affection occasionally displayed by the blacks for their employers. We had an instance in Port Darwin, but it was not made manifest until two men had undergone great hardships. Two of our residents went out to have a look at some tin-shows at Bynoe Harbour, just to the west of Port Darwin. When trying to make back to the boat the two men got bushed. In spite of numerous scarch- 


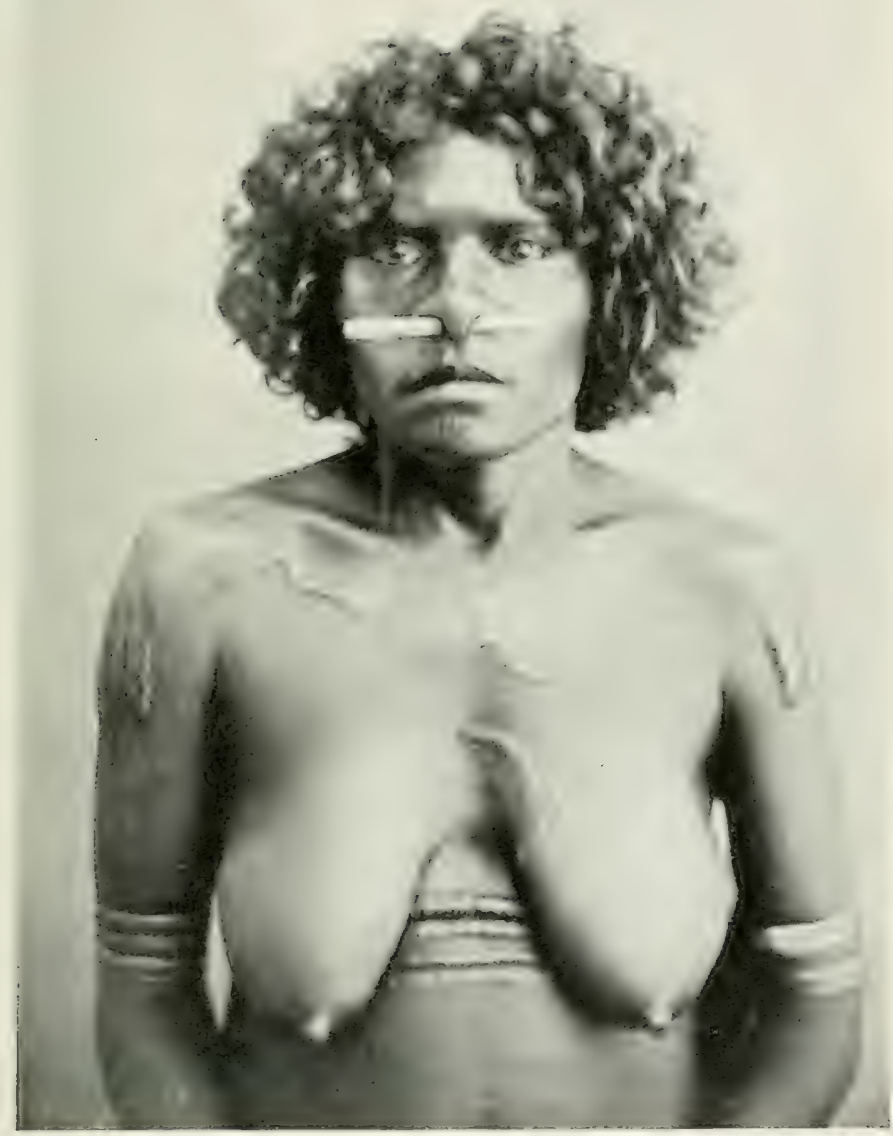

NATIVE WOMAN, PORT DARWIN.

X. Holtze. 

parties, it was many days before they were found. At last a party got on the tracks of the lost men, which they followed up for four days under the leadership of a nigger called 'Ginger Pop.' The boy had once been employed in an aerated-water manufactory, hence the name. At last the lost were found, and one of them was 'Ginger Pop's' boss. The black boy threw himself down alongside his master, and in between his sobs said, 'Oh, V. V., what for you — fool to go and get lost without me.' The two men were in a pretty pickle indeed. It being the wet season, they had not wanted for water, but their solids had consisted of marsh-flies.

Now, if those two men had made for the rising sun they would have struck the telegraph-line. However, out of pure cussedness, I expect, they determined to find their boat, with the result mentioned. We in Darwin blessed them, for it spoilt our Christmas. Those two men were satisfied that 'cold water and flies' did not make a very festive feed for the season of peace and goodwill.

We had in Darwin a high official who, at times, had business on the Overland Line. If this official were strong on anything, it was in showing respect to his superior officers and checking and cross-checking returns. On one occasion he was at Attack Creek, some fifteen or sixteen hundred miles from Adelaide, when he desired to speak to the head of the department in Adelaide The courteous official fixed his field-instrument to the line for the purpose of calling up Adelaide, but before doing so he instructed one of his men to remove a pack 


\section{IN AUSTRALIAN TRUPICS}

from one of the pack-horses and undo it. In the freeand-easy manner of the 'out-beyond,' the man said, 'What the _ do you want the pack for, Mr. ?' The official replied, 'I want my coat; I never presume to speak to my superior officer in my shirt-sleeves.' This happened in the middle of Australia. Having some voluminous returns to check, of which there were three copies, the official was assisted by two of his clerks, one being armed with a red, another with a blue, and the third with a black-lead pencil. One called out the items, which were ticked, then the returns were passed from one to the other and called out again, and yet a third, so each return had ticks from the three pencils. The official, to make what was certain doubly sure, said, 'Now we 'll change chairs and go over them again.' And so they did.

The Japanese honoured me with the title of ' $\mathrm{Mr}$. Custom-house Master-san.'

A little yarn about a Japanese, and then I have finished.

A Japanese tried to introduce prohibited literature by the false bottom trick. I prosecuted him, and he paid $£ 100$ fine like a man. He tried to ring the changes on me, however, for when his name was called out in Court a strange Jap came forward, but I happened to remember my man, so the trick did not work. The man who came forward was an employé of the genuine defendant, and a matter of six months in gaol would not have mattered to him, but the boss could not afford to go to prison, so paid up. When explaining the position 


\section{JAPANESE}

to the presiding magistrate, it seemed to me that he would not understand. However, a lawyer who was present rose, and on his using exactly the same words as I had done, the magistrate grasped the situation. I was a layman. It often struck me that judges and magistrates could be awfully dense at times, especially on matters of everyday life. Just before the case the magistrate had had what he thought was a little joke played upon him, some Japanese girls being the medium. When delivering his judgment in the case I have quoted, he leant over the table, glared at the defendant, and said in slow, cutting tones, ' I'll teach such people as you to mix with respectable citizens. You will pay a fine of one hundred pounds.' 


\title{
CHAPTER XXIII
}

\author{
PORT DARWIN
}

PORT DARWIN is one of the finest harbours in Australia, a harbour into which the largest steamer afloat can enter at any state of the tide, which means something when it is remembered that the rise and fall at springs is at times upwards of twenty-six feet, the mean being twentytwo feet four inches. So sure as to-morrow follows to-day this magnificent harbour will be the Singapore of Australia, provided, of course, certain works are undertaken and restrictions removed.

The work I refer principally to is the trans-continental line, an undertaking which is bound to be carried out in time, and which will connect the two splendid ports of Augusta and Darwin. Would not Port Augusta then occupy the place among the ports of Australia which its geographical position and its great facilities for shipping justify? Port Darwin would become a port of vast importance, a position which it rightly ought to occupy. Under the altered conditions I speak of, and backed up by the great natural resources of the Territory-it contains enormous regions of the best grazing land to be found on the continent, with a 



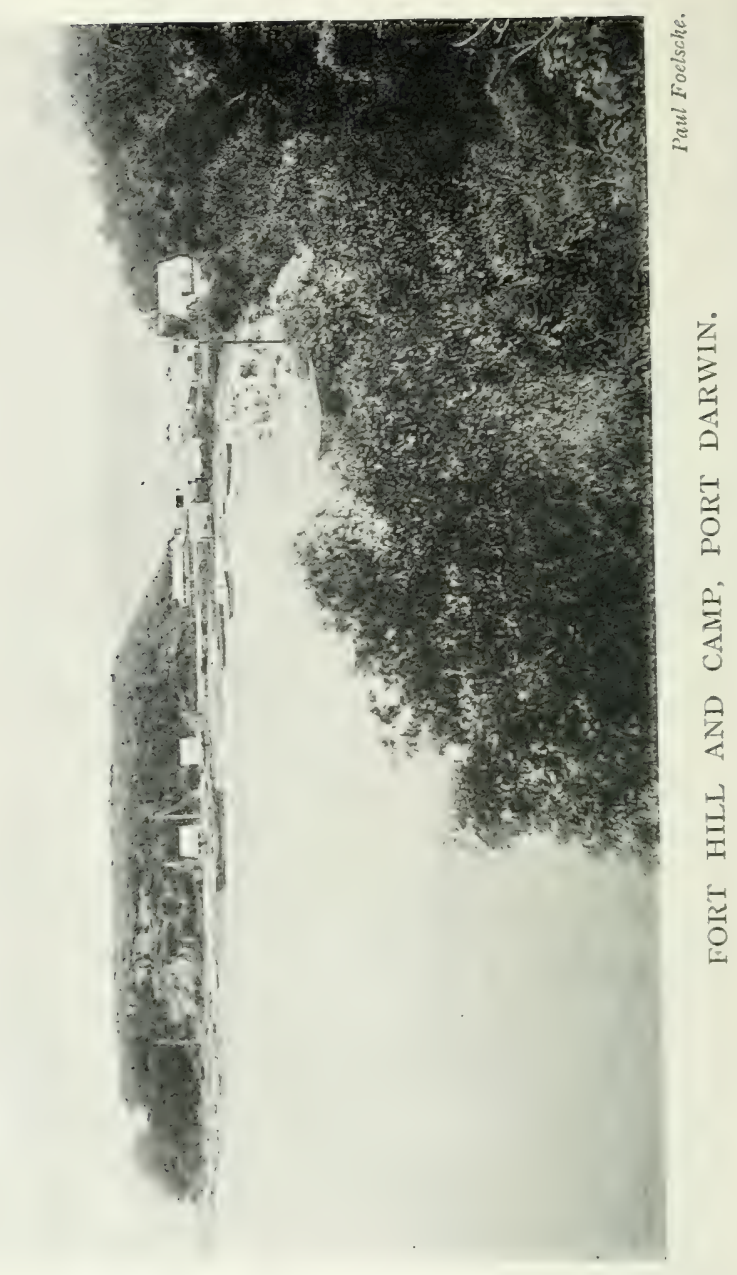




\section{PORT DARWIN}

splendid climate and an excellent rainfall, millions of acres of which are adaptable to settlement, besides being rich in gold and other minerals, of which very little is yet known-I repeat, that under such conditions Darwin would be one of, if not the greatest entrepott of trade in Australia. Consider for a moment if the railway were completed, and for the protection of British interests in the East troops were urgently required. One can realise the advantage of being able to rush them across Australia, and thence in fast steamers to their destination. When the time comes-and come it will-for Port Darwin to be fortified, it seems to me, as a layman, that it could be done with the greatest of ease and efficacy, and that it would be simply impossible for a hostile vessel to enter or get anywhere near the mouth of the harbour. What I want to particularly say about Port Darwin is that, in my opinion, it ought, from its position, to be the principal port of shipment for horses to India. Just read the following table, and then glance at the map, and you will see in a moment how adjacent India is, and that the steaming would be through comparatively calm waters : Brisbane to Calcutta vid Singapore, 6815 miles; Sydney to Calcutta viâ Singapore, 6305 miles; Melbourne to Calcutta viâ Singapore, 5740 miles; Adelaide to Calcutta viâ Singapore, 5250 miles; Fremantle to Calcutta viâa Singapore, 3872 miles; Port Darwin to Calcutta vîa Singapore, 3450 miles; Melbourne to Calcutta direct viâ Cape Leeuwin, 5660 miles; Melbourne to Calcutta viâ Torres Straits, 6750 miles.

As a port of shipment Port Darwin is an ideal place. 


\section{IN AUSTRALIAN TROPICS}

That fact was proved by the large shipments of cattle to the East. That magnificent horses-equal to any in Australia-can be reared in the Territory is beyond dispute. The paper published some time ago by Captain Cresswell, R.N., on 'The Export of Horses to India,' struck me as being most forcible, and I do trust that his idea may in the near future be carried out. The importance of the subject is very great, and every effort should be made to bring the matter before the public and those most concerned. The great rise and fall of the tide at Darwin has its advantages, for it enables vessels of large tonnage to be placed on the 'hard'-in other words, beached-for any necessary work that might have to be undertaken. There are several splendid spots in the harbour suitable for this purpose. I have seen such vessels as the Airlie, Guthrie, and Mcnmuir on the 'hard,' and important works carried out. In fact, there are natural docks in the harbour.

It does seem strange at the first glance that the Northern Territory has not made greater progress and has such a sparse population. Just look at the islands of Java and Mandura, not one-sixth the size of the Northern Territory, but which carry their teeming millions. The native population of these islands is now something over thirty millions. When I visited them some years ago the native population was twenty-six millions, and in addition there were five hundred thousand Chinese and fortynine thousand Europeans. At that time we had in the Northern Territory something like seventeen hundred Europeans, four or five thousand Asiatics, and a few 
thousand aboriginals. Of course, I know that Java is the tropical garden of the world, and we cannot for a moment compare the Northern Territory (as a whole) to that island, but it is well known that our possession contains land equal in size to the islands of Java and Madura suitable for any sort of tropical agriculture. Then why should not the Northern Territory carry a few millions instead of lying neglected? Let those who are responsible answer the question. It cannot for a moment be supposed that with such lands, backed up by the finest cattle- and horse-breeding country in Australia, the Northern Territory is to remain dormant, and the grand harbour of Port Darwin wasted-a harbour which Nature has provided with an admirable site for a town. It is healthy and naturally drained, being some seventy feet above the sea-level. And why should not this magnificent harbour be made more beautiful, picturesque, and tropical in appearance than it is at present, by planting on the numerous suitable spots adjacent to the sea cocoa-nut palms. We have sufficient evidence that the palms will grow in the splendid avenues in the Botanic Gardens under the superintendence of Mr. Nicholas Holtze, the curator. Spasmodic efforts were made many years ago to grow palms, but neglect, bush-fires, and white ants proved too much for them. When I left Port Darwin there was only one of the palms left, and that was growing almost on the beach at Fanny Bay in spite of every adverse circumstance. If I had had my way every available spot in the harbour would have been planted with palms, and niggers would have been em- 


\section{IN AUSTRALIAN TROPICS}

ployed to look after them. The white ants would be the worst enemy to contend with, but constantly working the soil round the roots, as before stated, has a beneficial effect, for these pests do not like being disturbed. Many years ago, when the Young Australian was on the coast, nuts were planted at many spots between Darwin and the Roper. They did not grow; not, however, because of the white ants, but owing to the Myall niggers, who dug them up as fast as they were planted, and ate them.

The pine-apples grown by the Chinese gardeners, principally on the side of the stony ridges forming the gullies, I believe, are unsurpassed. Globe-trotters have often informed me that in no part of the world had they tasted such exquisite fruit. I have eaten those of Singapore and Queensland, and I honestly say there is no comparison. To eat a Port Darwin pineapple-one with the rough skin, properly trimmed by a China boy, whereby every seed is removed, tearing the edible portion from the stem with a silver fork, with just a dash of salt-well, it was an experience I never tired of. The papya or pawpaw apple grew anywhere and quickly, but the white ants played havoc with the trees. The stems are nice and soft, and I am certain must have been an agreeable change from the hard things the ants used to tackle indiscriminately. The papya is a prolific bearer-that is, the fomale tree; the male tree bears long sprays of creamy white blooms delicately scented, and when in fruit presents a peculiar appearance. The fruit grows in clusters round the stem, and is surmounted by an umbrella-shaped mass of large 


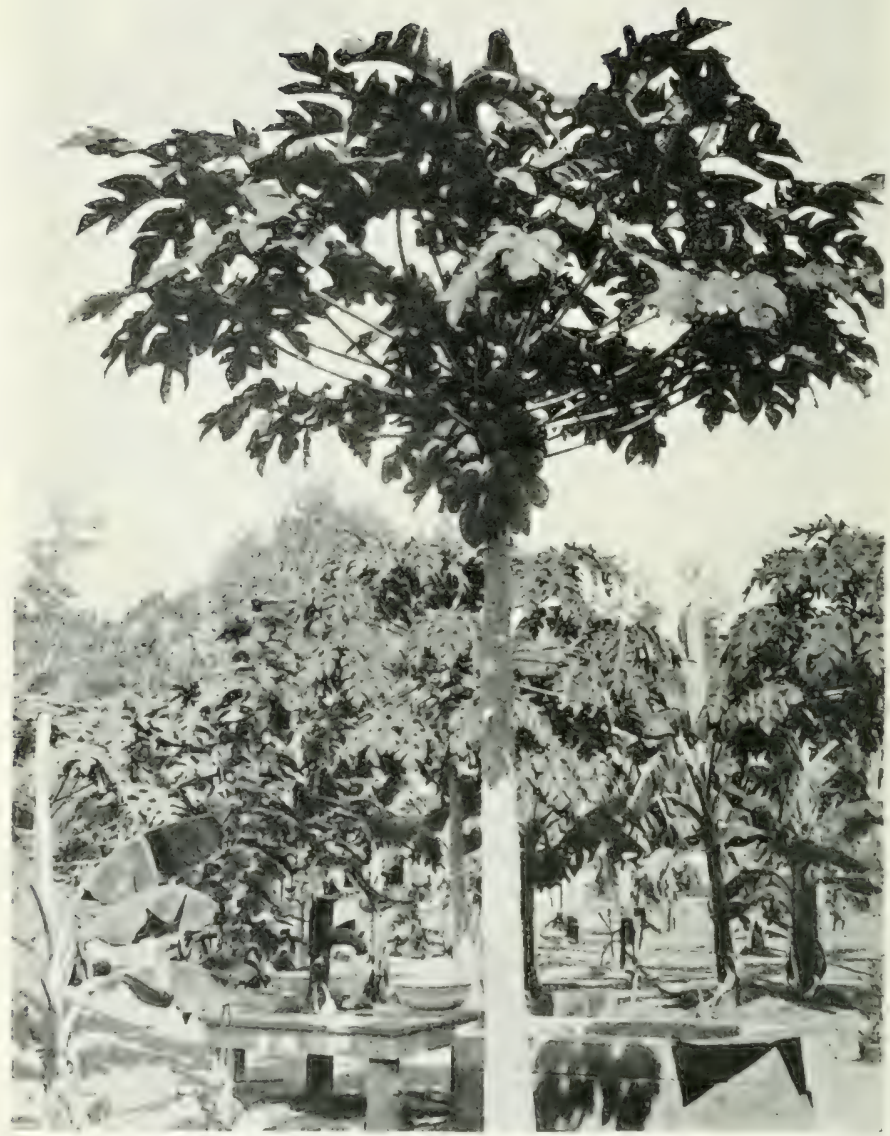

II. W. Christie.

PAPYA (PAW PAW APPLE) TREES, POIN'T CHARLES. 
leaves. I have never experimented, but it is placed to the credit of the papya that the toughest of meat can be rendered tender by hanging it under the leaves for a few hours, or by wrapping it up in them. What a blessing it would be here sometimes!

I have already mentioned that the flying-foxes are particularly partial to this fruit. I have often in the early morning gone among the trees at my quarters to pick out a fine fruit I had spotted the previous day, only to find that it had been hollowed out during the night. The words used were enough to make the tree look sad. Cut the papya in half lengthways, scoop out the seeds, and then, with a dash of sherry and a spoon, you have something to think about.

The custard apple I soon tired of. It was too rich and sweet, but the soursop, a peculiar fruit which has an American name not used in polite society, was at all times a favourite with me. I always understood that the only way a mango could be eaten was while in a bath. I never found that actually necessary, but it was just as well to wash your face after a good struggle with one. What a delicious thing a good mango is, to be sure. When you get the chance, have them off the ice.

I have heard the mangosteen called the queen of fruit, and it deserves the name. I never seemed to be able to get outside enough. When you get a good ripe pumelo you have a treat, especially if it has been in the ice-chest all night, or out in the air with a damp cloth round it for a time. Limes do well there, but for hot grog I prefer the good old lemon. Oranges also flourish. 


\section{IN AUSTRALIAN TROPICS}

For a delicious early morning drink I recommend you to try the milk from the green cocoa-nut. Cut off the top of the nut with a sharp knife, pour the contents into a glass, and you have a drink fit for a king. The cocoanut must be cold. When in Singapore I was a bit seedy, and consulted a doctor. Part of his prescription was cocoa-nut milk first thing in the morning. I took to it most kindly, and often wish now that I had a chance of repeating that portion of the cure. Have you ever eaten the dry lychee? Just take a hint if ever you purchase any! Pick those which have the appearance of having been pressed between the thumb and finger in preference to those which are perfectly round, and you will soon find the difference. The fresh lychee is very: fine. I did not care much for guavas fresh, but made into jelly they are a dream. Jack fruit is also grown. It is similar to the durian, which it is advisable to partake of in the open air on account of the obnoxious smell which emanates from it. When in Singapore I tackled the durian, and delicious it was. The smell was powerful indeed, but once having tasted the inside one forgets the objectionable aroma. The jajube, 'granadilla,' common passion fruit, and mulberries also thrive well.

I have already spoken about the marvellous watermelons produced in the Territory. Then again, what magnificent rock-melons we used to get, to be sure. I'll just tell you how to eat the mash-melon as a wind up, for I think I have given a fair idea of tropical fruits procurable in Darwin. The mash-melon is ready for use when it splits open; remove the seeds and skin, 



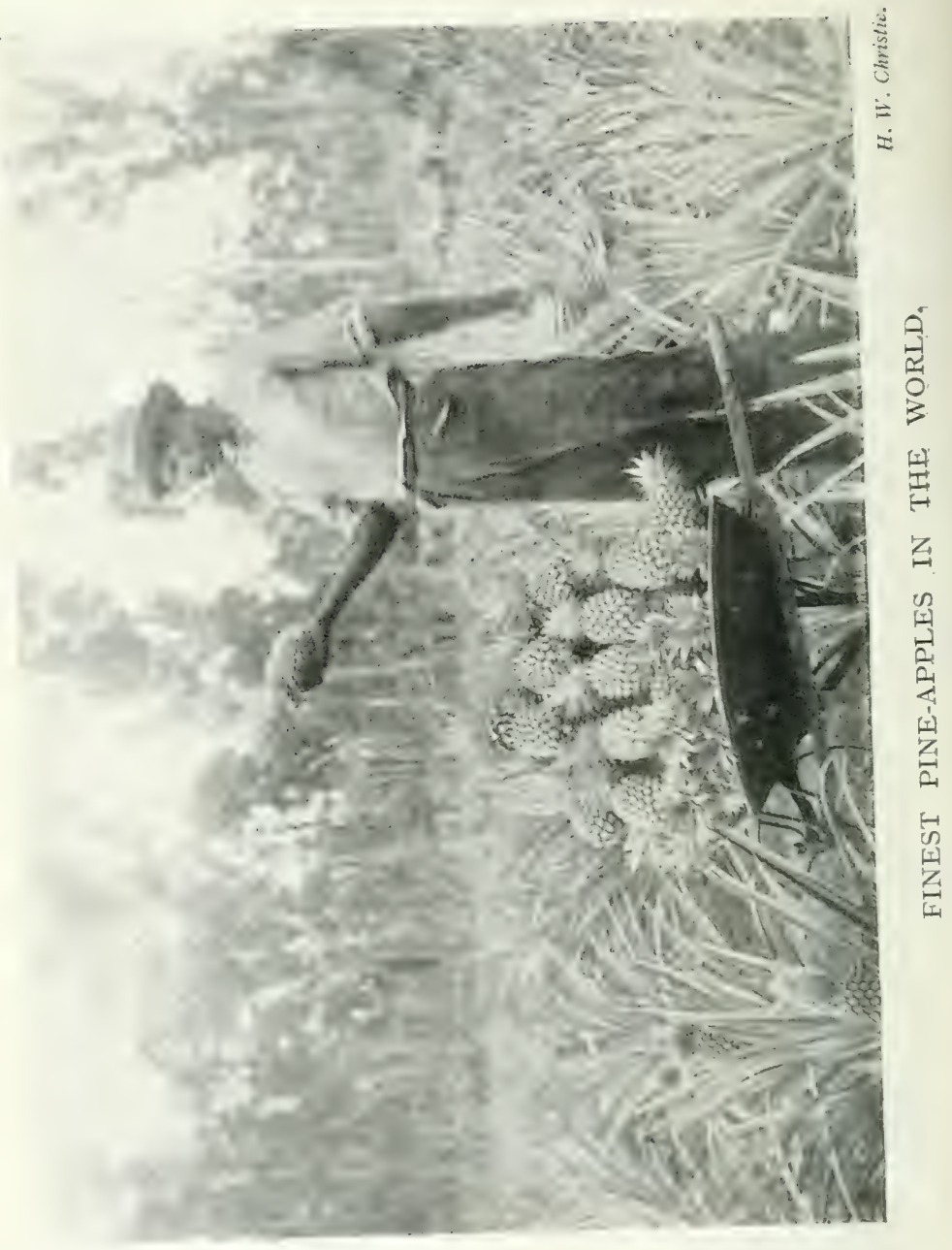


mash up the inside with sugar, and add a dash of rum, sherry, or lemon-juice, and then proceed to business.

Now all these fruits were grown, as I have said, in the Territory, either in the Botanic Garden or by the Chinese gardeners. Dr. Maurice Holtze did splendid work in introducing the bulk of the fruits, and these efforts have been continued by his son, Mr. Nicholas Holtze.

The area suitable for the growth of pine-apples is simply unlimited, so in the future, when circumstances are different, a nice little industry may be established in preserving them. What an eye-opener it will be for the southern people, when they see train-loads of pineapples, bananas, and other tropical products delivered in Adelaide. Such will be the case when the transcontinental line is built, which must come in the near future. From the above you may judge I was a great fruit eater. In my quarters I always had a table standing in tins containing keroserue, to prevent the small black and red ants from invading it, carrying plenty of fresh fruit. This was kept supplied by a Chinese gardener without reference to me. The small ants referred to are an awful nuisance. Where they come from, and the quick appearance they can put in, are a marvel. If anything is calculated to rouse one out of his bed and compel him to shake, it is these ants. If you happen to put on a garment with some of them on it, they make things lively.

The residents in Darwin were all supplied with fresh vegetables, and for this blessing they had to thank the Chinese gardeners, who simply worked like slaves in 


\section{IN AUSTRALIAN TROPICS}

their gardens, which was necessary when the dry season was taken into consideration. It would have been a poor lookout if it had not been for the patience and perseverance of the Chinaman. Good as the vegetables were, I'll own in this particular to have a preference for those of temperate climates, although I often think that a good meal of sweet potatoes or yams would not be bad.

I have often been abused because I always said that I preferred the tropical fruits to those of a temperate clime. During my long residence in the tropics I never tired of the fruit.

There are no indigenous fruits of any great value or particular flavour in the Northern Territory, consequently all the well-known tropical fruit-trees had to be imported. The bananas, of which several varieties are grown, were simply perfection. I often wish now that I could secure a bunch ripened on the tree and hung up in the verandah as we did, so that you could help yourself and come again. The most delicious, I think, were those known as ladies' fingers.

It is just as well to tell the truth about the Northern Territory. I heard the other day that a gentleman, who had resided many years in our northern possession, stated that that portion of the island continent was the healthiest country in the world, that malarial fever was a bogie, and that any tropical products could be produced successfully with European labour. I am afraid that that gentleman forgot that there are in the world a few other people who have experience of tropical countries and tropical life and production, and who, if they saw or heard 
such statements, would naturally ask why such a tropical paradise had been neglected so long, and had developed into what is known as 'the white elephant'? They would at any rate imagine that there must be a screw loose somewhere. Now it must be realised that we have a veritable tropical Australia, and the sooner that fact is understood the better. The conditions are just the same as obtain in other portions of the tropical world-the same ills have to be borne, and similar means are necessary for the development of the country. Why not recognise all the country to the north of the twenty-second parallel of latitude as 'tropical country,' and develop it under tropical conditions? It must be remembered that portions of the Northern Territory are looked upon as supplying some of the hottest places in the world. It seems to $m e$, in the circumstances, rather absurd to say that malarial fever is a bogey. As a matter of fact, it does exist, especially during the early portion of the dry season. I firmly believe, however, that for a tropical country the Territory is one of the most healthy in existence, and I know that Europeans, under certain conditions, stand the climate perfectly. Speaking for myself, during my fourteen years' residence there I had splendid health, with only slight touches of fever; but it must be remembered my work was on the coast, which is a great advantage. I was sorry enough to leave the Territory; in fact, I would not have done so, but that the health of my wife and children necessitated the change. The charm of a tropical life was fully developed in me, although in Northern Australia one has all the dis- 


\section{IN AUSTRALIAN TROPICS}

advantages of tropical life without the compensating advantages peculiar to the East. The gentleman I referred to, I fancy, must have spoken from his actual experiences, which were evidently gained on one of the cattle stations, and it is generally recognised that no more healthy places could exist, while the work peculiar to station life and droving are suitable for Europeans. I dare say more white men could be employed if it were not for the black boy's, who are peculiarly adapted for the business, and are in many cases better than white men. I may be prejudiced, but I cannot imagine anything more enjoyable than a trip to Port Darwin. To those who are anxious to see something fresh and new, to see a country about which so little is known, the Territory is an ideal placc. What I should like to see is a party of rich, adventurous young Englishmen charter a steamer, and put in a few months on the north coast. Supposing such a thing did eventuate, they ought to be there by May, just as the south-eastern monsoon commences, and then they could work their way along the coast, doing a little exploring, prospecting, and hunting; they could always make good shelter. With a small launch they could ascend the numerous rivers and streams, many of which have never yet been navigated, or perchance discover new ones. They would have great shooting, and see new country. They could visit the adjacent islands, which are full of interest, and are remarkable for fine scencry. Photographs could be taken of scunes which never yet have been reproducerl, and in many instances have never yet been 


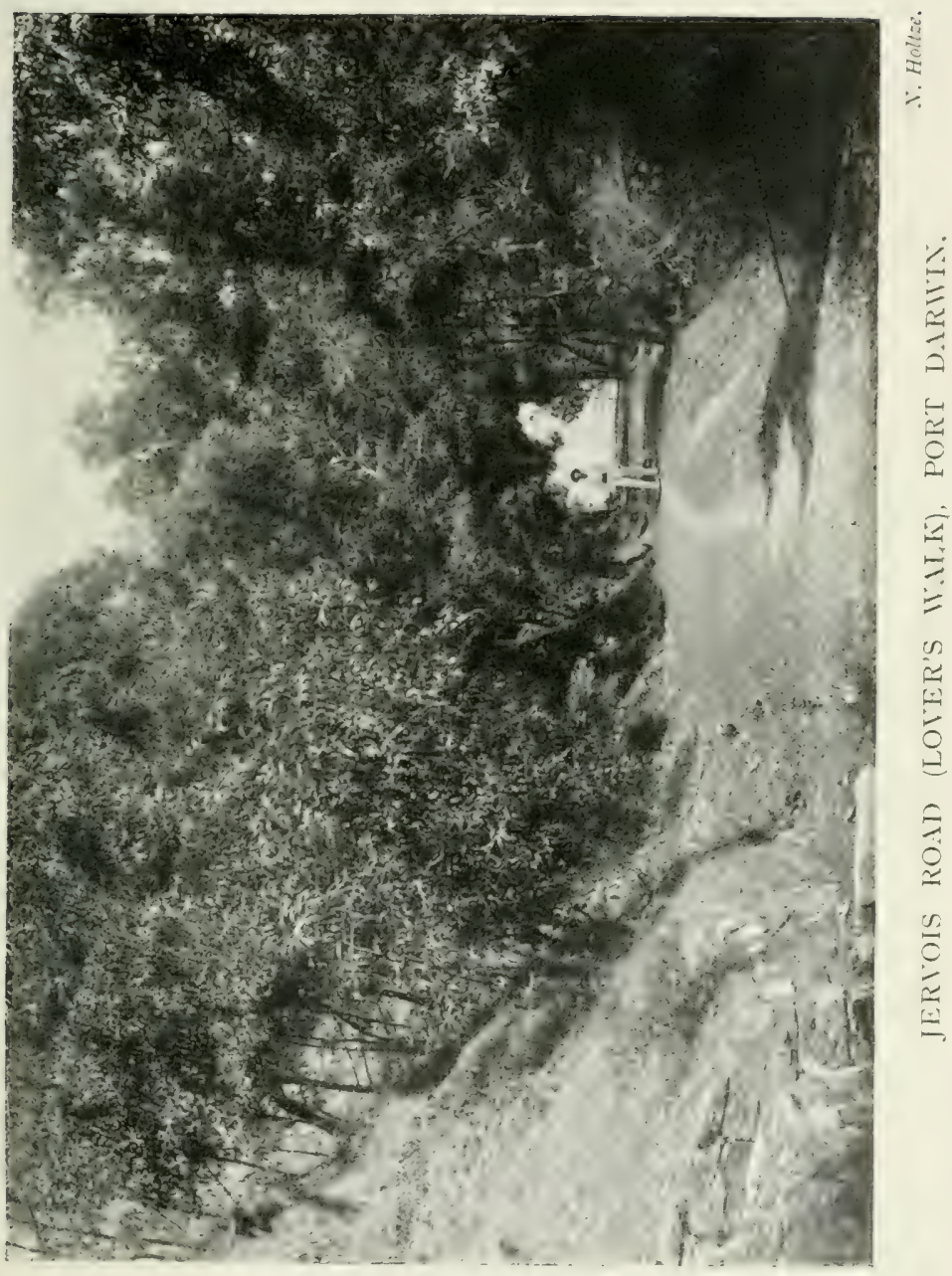





\section{A GRAND CHANCE}

seen by Europeans. What a chance for the botanist, the naturalist, the geologist, and many other 'ists'! What an opportunity for a man with a literary taste to make a world-wide name for himself! Of course, we have not the wild animals found in other parts of the world, but still there is grand shooting. The Myalls may not be so far advanced as the wild tribes in other countries, but if such a party as I have spolien of were to run up against a crowd of them, I am certain they would be satisfied with the result.

Port Darwin can always be reached by the magnificent steamers calling there when $c n$ route from Hong-kong to Singapore. If visitors should take the southern route the cruise through the Barrier alone is well worth the trouble. The best months of the year for knocking about the Territory are from May to August. To my idea there is no finer country or a place with circumstances more favourable for steady, reliable young men to open out than the Northern Territory, provided that, after having paid the passage, they have enough to keep the wolf from the door for a period during which they could look round, and decide in what dircction they would put forth their energies. People going to the Territory must not for a moment think that life there is all beer and skittles. They must be prepared to undergo certain hardships, and many inconveniences, especially those peculiar to a tropical country. It is no use for the man who will get home-sick right away, or at the first sign of sickness or real graft will get his tail between his legs, chuck the whole thing, and damn 


\section{IN AUSTRALIAN TROPICS}

the country. In my opinion sober men have not much to fear from sickness if they observe care. I do not say that it is necessary to abstain from intoxicants, but I am satisfied that the less taken the better. I do not suggest that white men should actively engage in the cultivation of tropical products on the coast, or rivers, or swamps, for I am of opinion that that can only be carried out by coloured labour.

What a number of people who have visited Port Darwin, or simply passed through, have grateful remembrances of the B.A.T. quarters - the cable stationBritish Australian Telegraph Company, it used to be, but now it is the Eastern Extension, Australasia, and China Telegraph Company; but the B.A.T. it always is to Port Darwin people, and B.A.T. it always will be. During my time there is no mistake the officers were a grand lot of fellows, hospitable to a fault; in fact, they were in a great measure responsible for the good name Port Darwin received from visitors. At the quarters there was a tennis-court, billiard-room, and readingroom, the last named being often turned into a ballroom, and all those accessories which make the lives of officers stationed at a tropical outpost pleasant. When those men had a dance on, it took something to stop it. Just an instance. Invitations for a ball had been issued, but when the hour approached for the guests to arrive, it came on to rain in torrents, and grew deadly dark. Did the B.A.T. men give it best? Not much! They secured a trap, one man driving, another walking ahead with a lantern, and so ran the guests in. The event was 


\section{THE B.A.T. MEN}

a huge success. What grand 'buck sprees' we used to have there, to be sure; a lot of men together, pure fun and frolic.

The officers at one timc had a pet ram which was called Billy. He had a coat of many colours, one day white, then red or blue, or a little of both. Now Billy had a great aversion to people turning their backs on him or moving hurriedly, for as sure as such a thing did occur, Billy would charge with most surprising results. I have known Billy clear everybody out of a store when he spotted some one who had not treated him with proper respect. One day there were three of us standing talking in the street when Billy appeared. Thinking to give one of my chums a surprise, I moved hurriedly round in front of him, thinking that Billy would charge the man who liad his back to him, but the ram was not taking any jokes, so went for me and landed me in the middle of the dusty road. Billy evidently carried his little games too far, for one morning he was found stiff and cold. What a time the niggers had, for it was not every day they had jumbuck. I should think that indiarubber would have been tender in comparison with poor Billy.

There were also at the quarters two of those graceful birds, the native companion, which were a source of great admiration and amusement to visitors, their dancing and antics being most entertaining. It was a great sight, when the gong went, to see them scratch gravel, for it did not seem to matter in what portion of the compound they were, they were generally the first men in the messroom. They had a playful habit of pecking at you 


\section{IN AUSTRALIAN TROPICS}

unawares, which was rather disconcerting at times, for they did not discriminate when and where. They also died.

Wherever Englishmen are gathered together there is racing, of course, if it is possible to raise some sort of a quadruped, and Port Darwin was no exception to the rule. Once a year we had our spree, and a great time it used to be in the old days, when nearly every man who possessed something with four legs would enter it for one of the events at least. Of course, the meeting was held during the dry season. The horses, many of which picked up a precarious existence on their own account, were suddenly fed, groomed, and taken out regularly for exercise. What enthusiasts the fellows were, to be sure! They would roll out before daybreak and face the bitter south-easters most manfully. The racing itself caused plenty of fun and excitement. Immediately the meeting was over most of the horses must have realised the fact, for once again it became a matter of scanty herbage, dry sticks and stones. At last one of the local people imported a crack racehorse, which naturally knocked the old style of race-days sky-high, and rang the death-knell to the genuine amateur meeting. Now horses from all parts of the out-bcyond attend the annual fixture at Port Darwin.

Port Darwin was a favourite calling-place with all the officers of the regular steamers. It may be taken for granted that we Port Darwin penple did our best to make things lively for our visitors. If time permitted, there would be shooting at the lagoons or jungle, driving, moonlight picnics, card-parties, dances, and buck sprees. 


\section{A FAVOURITE SKIPPER}

The steamer pcople were not backward in reciprocating, for they always did their best to give us a good time on board. Good fellows and universally liked as the officers were, yet one skipper stood out as prime favourite. The one I refer to was the epitome of a British seaman-short in stature, but of great breadth and strength, a daring and skilful navigator and a great disciplinarian. He was a man with a magnetic charm all his own. I think it is generally accepted that children and dogs are wonderful readers of character, and it was children who instinctively understood the character of this man. I have seen young children almost jump from their mothers' arms into those of the said skipper although a stranger to them. To all the children of a larger growth there was the same attraction.

He had a charming voice, yet when occasion arose and it was necessary to be emphatic or he was angry, his voice shot out like the sound from a pom-pom, and demanded just as much attention. He was always up to some fun. I remember once on one of his trips from the south he had as passengers several wives returning to their husbands, and one or two girls coming to be married. To give them privacy, as he said, he had canvas rooms rigged up all round the poop, and on the curtain in front of each the names of the wives or intended wives, so when husbands or lovers came off, they knew where to find their better halves or sweethearts. The skipper boarded a horse one day and went for a ride. Suddenly the people were astonished to see a horse tearing into the town with the rider facing the 


\section{IN AUSTRALIAN TROPICS}

stern. The jolly old salt thought he would like to try what the sensation of riding backwards felt like, and of steering while facing the stern. He arrived at the conclusion that as a change it was amusing, but as a general thing, at least for a true British captain, it was not advisable to indulge in that style of riding. We had some tame Indian (ghee) buffalo knocking about the town, and my friend, wanting to pay a visit at my quarters, caught one of the animals and rode him down. It was a wonderful sight and passed off all right, the buffalo being too astonished at such a liberty to resent it. How that animal must have laughed when it saw the skipper's beautiful white clothes, white no longer. One evening the skipper rigged himself up as a man-o'war's man, the dress having been used at one of our fancy dress balls, and went for a cruise round the town. Now it happened that there was in the harbour a large yacht of the Royal Yacht Squadron, the Kooshie Doo, some of the crew being Royal Naval Reserve men. These men spotted our skipper and arrested him, and threatened to have him locked up for wearing Her Majesty's uniform. He had a lot of trouble before he could get clear. The best of it was that there was a skipper of the other line of boats standing by all the time and enjoying the fun. My friend had a most wonderful chest measurement, which he could increase it la Sandow until his chest stood out like a pouter pigeon's. When in Hong-kong once a Chinese tailor measured the skipper for some clothes, his chest at the time being expanded. When the Celestial waited on his customer with the clothes to try on, the chest was 
drawn in. The Chinaman looked astonished as he viewed the coat hanging like a sack, and said, 'What for?' However, he remeasured the skipper and altercd the clothes accordingly, but when the second suit was tried on, the chest was again expanded to the fullest extent. The Chinaman was dumfounded. The skipper paid for the clothes, and no doubt the look of astonishment and doubt on the Chinaman's face was well worth the outlay.

The genial skipper was loved and respected by all ashore, and also by his officers and crew. Any one who ever met the subject of this sketch will recognise the skipper I refer to. He is now the shore boss at an important end of his old Company's line.

To those who have passed through Port Darwin, many pleasant recollections will be recalled by the mention of the names of the steamers and their captains: the Brisbane, Menmuir, Tannadice, Catterthun, Guthrie, Airlie, Eastern, Australian, and Empire, of the Eastern and Australian Line, and their skippers, S. G. Green, Robert Craig, Hugh Craig, Darke, W. Ellis, P. Helms, M'Arthur, Dable, St. J. George, Shaw ; and the Whampoa, Woosung, Taiyuan, Changsha, and Tsinan of the China Navigation Company, and their skippers, J. E. Williams, A. Hunt, R. Nelson, T. Moore, Ramsay, G. Innes, and Allison.

Occasionally the British India steamers called. I well remember the first one which visited our port. When we went out to board her we found she was inside the line where vessels had to stop until pratique was granted. We went out to sea a bit in our launch, so the steamer had to follow us. We then refused to 


\section{IN AUSTRALIAN TROPICS}

board the boat until a bit of a lee was given and a proper ladder lowered. When on board, the skipper said to me, 'You are a small place, but you put on a — lot of side.'

'Yes,' I replied, 'and you just remember that you have not a - lot of coolies to deal with.' We were the best of friends afterwards. 


\section{TRANSFERRED SOUTH}

\section{CHAPTER XXIV}

FAREWELL TO PORT DARWIN

IN May I\$g6 I received word that I was to be transferred south to the position I now occupy in the South Australian House of Assembly. It was necessary for me to seck the transfer on account of my wife and family, whom I had not seen for some years. Otherwise I should have been content to have stayed on in Port Darwin for all time.

It is a strange fact that all who have lived there for any lengthened period deeply regret leaving it, and have always the craving to get back again. I honestly believe that not a day has passed since I departed from the dear old place that I have not thought about it, and in my mind felt the hard, dry, cold south-easters, and listened to the plaintive 'klee klee' of the bromli kites, for to me these birds are always associated with the south-easters.

In memory I have passed through the hot season, and then, above all things, stood out the health-restoring, invigorating nor'-westers. The effect of a nor'-wester after a south-easter on me-in fact, I think I can say most people-was similar to that, so I am credibly informed, of a bottle of good champagne on a person after a bad night. 


\section{IN AUSTRALIAN TROPICS}

I shall ever remember my departure. I stood behind one of the boats watching my old chums gradually disappearing, and the receding shores where I had spent so many happy years, the tears rolling down my cheeks, when all at once I received a heavy blow on my back, and a voice yelled in my ear, "What are you crying for, you — old fool?' It was Tommy Moore, the chief officer of the steamer, who had spotted me, and the sight of my grief had so touched him that he adopted this drastic means of getting it off his chest.

For some time we had in the Customs gig a great, stalwart Japanese named Mingo, who also acted as office-boy. He had at one time been a soldier, and fought in Acheen. Mingo lived at my quarters for a time. One evening we had a dance, which I suppose disturbed Master Mingo, for, getting tired of the frivolity, he suddenly appcared on the verandah with a lighted lantern and a clock. He coolly walked round, and deliberately held the lantern and clock in the face of each guest in turn. The timepiece indicated half-past two. Our friends, who fully appreciated Mingo's gentle hint, immediately departed. Having recalled the incident, and in case some of my readers might think it time that another Mingo produced a lantern and a clock, or perchance a shooting-iron, I will act on the suggestion conveyed so nicely and delicately, and close the story of my experiences. 




\title{
Northern TERRITORY
}

\author{
of Australia. \\ POINTS FOR IN'TEXIDING SET'TLERS \\ See following pages.
}

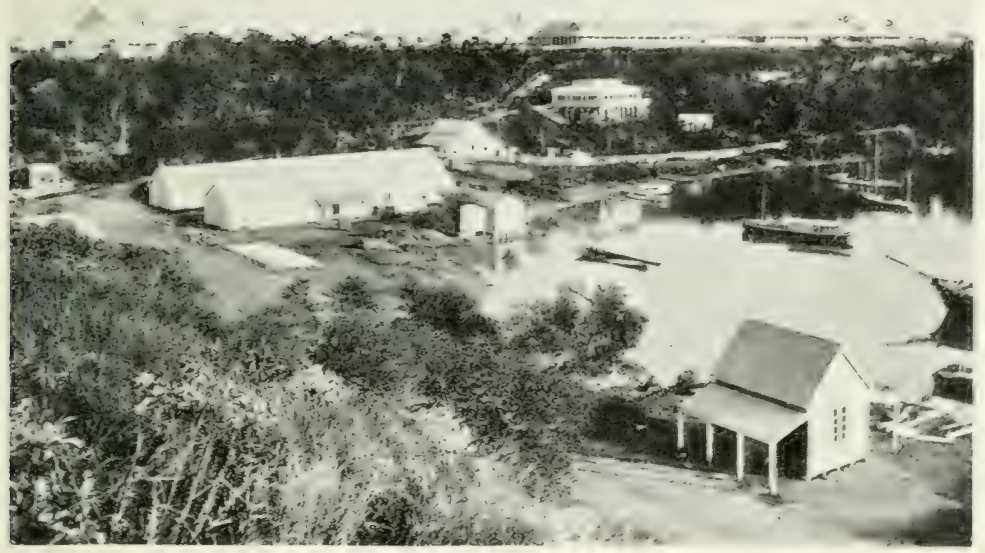

TOWX OF DARWIX.

\section{CLIMATE}

TR O P I C.1 I, TO 'TE. I PER.1'T'E.

Most Commercial Plants are easily cultivated.

Full details on application to the Department of External Affairs, Melbourne, or to the Administrator, Darwin.

BY AUTHORITY OF

The Hoyorable the Mixister for External Affairs. 30 th April, IgI2. 


\section{NORTHERN TERRITORY}

$\mathrm{OF}$

\section{AUSTRALIA.}

THE CENTR.II, STITF OF THE CONMONITELTH.

THIS MAP shows the relative position of the Northern Territory to the other States of Australia.

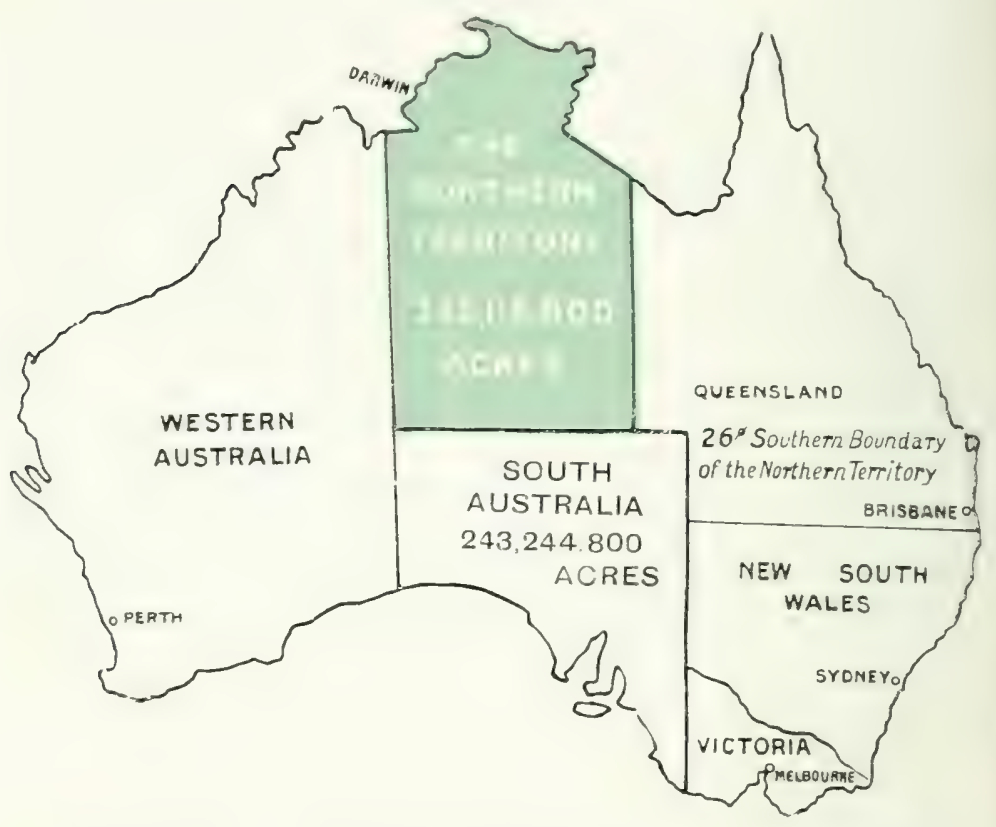

THE AREA of the Northern 'Territory is $335,116,800$ acres. and affords a grand opportunity for the selection of land, for a home, by men of energy and industry, who have a little money.

LETTERS OF INOUIRT can be addressed to the Secretary,

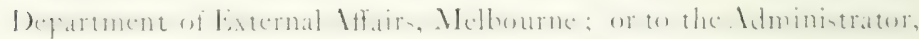
Darwin; or to the High Commissioner for the Commonwealth of Australia. I,ondon. 


\section{NORTHERN TERRITORY.}

$7 H E$ control of the Northern 'Territory is now vested in the Government of the Commonwealth of Australia, who are prepared to spend considerable sums of money in developing its resources.

EXTENSION OF RAILIVAYS.-By virtue of the contract of transfer a railway line will have to be constructed to connect the existing line in the Territory which extends over I 50 miles S.E. from Darwin to the South Australian railway system.

It is possible, however, that other lines may also be constructed and new harbours opened to assist in obtaining the fullest advantages from the uncloubtedly great resources which the Territory atfords.

EXPERIMENTAL FARMS.-The Government are now conducting extensive experiments in different localities with a view to ascertaining what products are likely to be most profitable to the settler.

LIBERAL LAND POLICY.-Details of the very liberal land policy will be found on subsequent pages, but special attention is invited to one special feature which enables those who are prepared to undertake the hardships inseparable from a pioneer's life to reap a substantial reward, that is that they will have possession without cost for the whole of their lives of the agricultural area which they have taken up.

The Government are undertaking extensive inquiries in every direction, notably mining, and the results in this direction will be published from time to time and may be had on application to the Department of External Affairs, and the Administrator, Darwin.

As one of the terms of the transfer of the Northern Territory from the control of South Australia to that of the Commonwealth it is provided that all existing interests are preserved. Consequently all leaseholders under the laws framed for the Territory by South Australia will continue during the currency of their lease on precisely the same terms as to rent, improvements, etc., as previously.

\section{LANDS.}

In regard to lands to be dealt with hereafter an entirely new policy has been adopted, its main principle is PERPETUAL LEASING.

No land of any class will be available for acquisition under the new law until it has been classified and advertised as available. This classification will be made by a board of independent officers who will assess the rent to be charged and fix the improvements which are to be carried out.

The object of the law is to induce persons to settle on the land-its terms consequently will be perhaps more liberal than those of any other country.

PASTORAL LANDS will be classified according to their stockcarrying capacity into three classes, and a maximum area in each case 


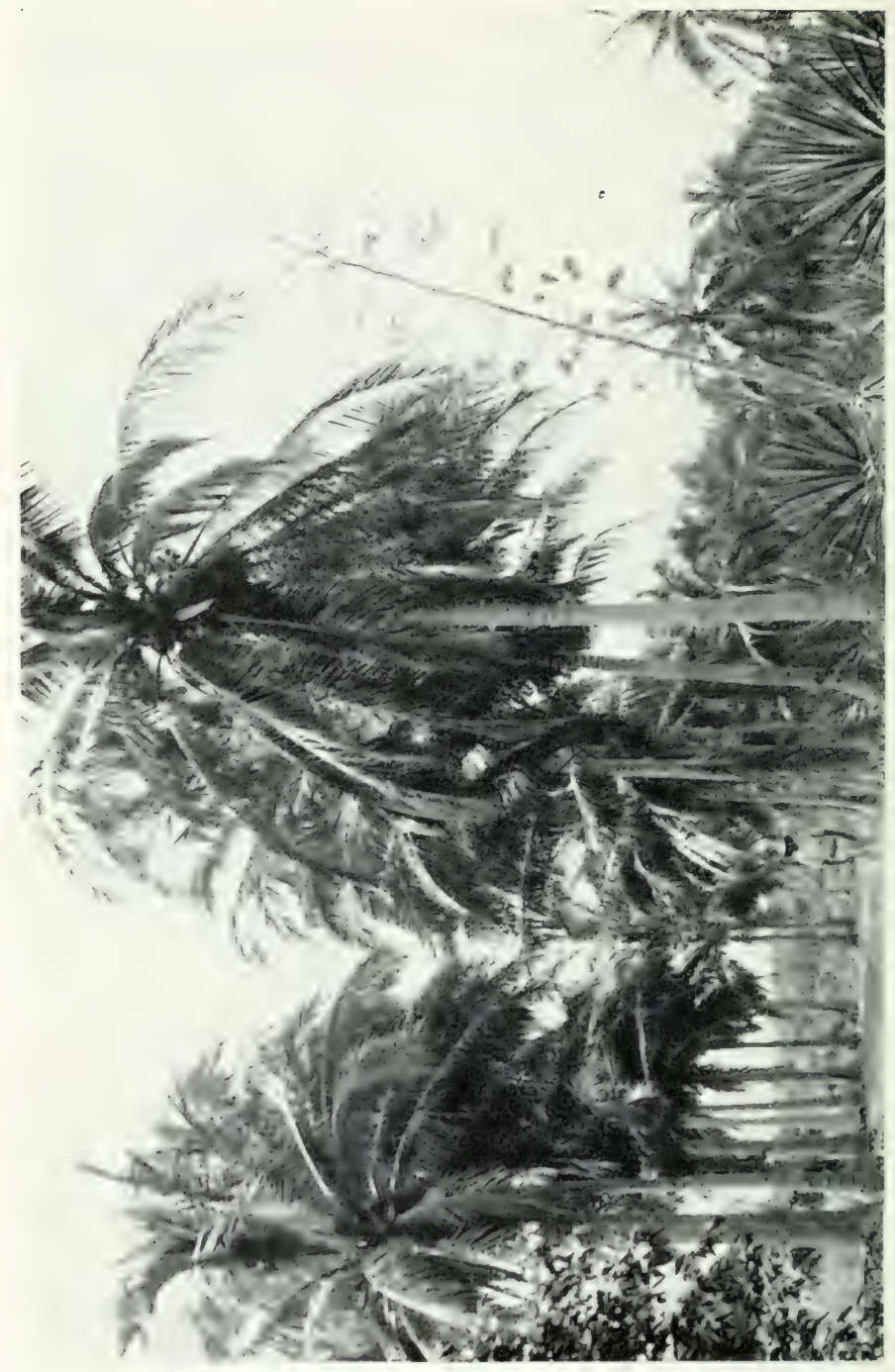

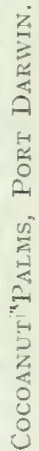


is fixed which will be amply large for men intending to work their properties themselves.

Of the first class lands the maximum area of a single lease will be

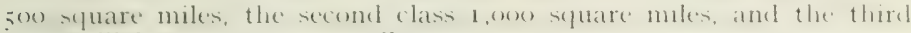
class will be 3,000 square miles.

AGRICULTURAL LANDS will be divided into two classes:-

(a) Cultivation Farus intended for persons devoting themselves to pure agriculture - the areas of these will be :-

Class I. Maximum area-6, 0 acres.

Class 2. Maximum area-2,560 acres.

(b) Mixed Farmixg Axd Grazixg Blocks for persons who desire to combine stock raising with cultivation. The areas of these will be :--.

Class I. Maximum area-12,S00 acres.

Class 2. Maximum area-6, -000 acres.

As soon as any of these lands are classified full particulars will be obtainable of everything necessary to be known by a settler who contemplate's making application for land in the Sorthern lerritors:

All leases are perpetual.

Rent will be reappraised every twenty-one years.

The first ;,000 blocks of agricultural land taken up will be rent free during the applicant's life, or for twenty-one years from the commencement of the lease, which ever period is longer. Settlers will, therefore, have no anxiety (luring their life as to being able to retain their holding.

The rentals on all lease are subject to reappraisement every twentsone ycars; such reappraisement will be carried out by the Classification Board, and if the lessee considers his reappraised rental to be excessive he will have the right of appeal to a court which shall consist of the Judge of the Supreme Court, with two assessors, one nominated by the Director of Lands and one by the lessee. Every precaution has thus been taken to assure prospective settlers that they cannot suffer any injustice.

Even though the lease is perpetual, the lessee may, subject to the Administrator's consent, transfer either the whole or any part of it.

It is intended that assistance shall be given by the Government to bona fide settlers in the way of advances to assist in improving their property.

\section{MEANS OF TRANSIT.}

STEAMERS CALLING AT DARUTN.-Vessels of the Eastern and Australian Steamship Co., Ltd., Burns, Philip and Co., Ltd., and the China Navigation Co., Ltd., equipped for the Australia-SingaporeManila-Hong Kong-China-Japan trade call at Darwin once a month.

UNITED KINGDOH AND EUROPE TO DARUIN.-Darwin can be reached from the East via Vancouver or San Francisco, or from the West via Singapore. 


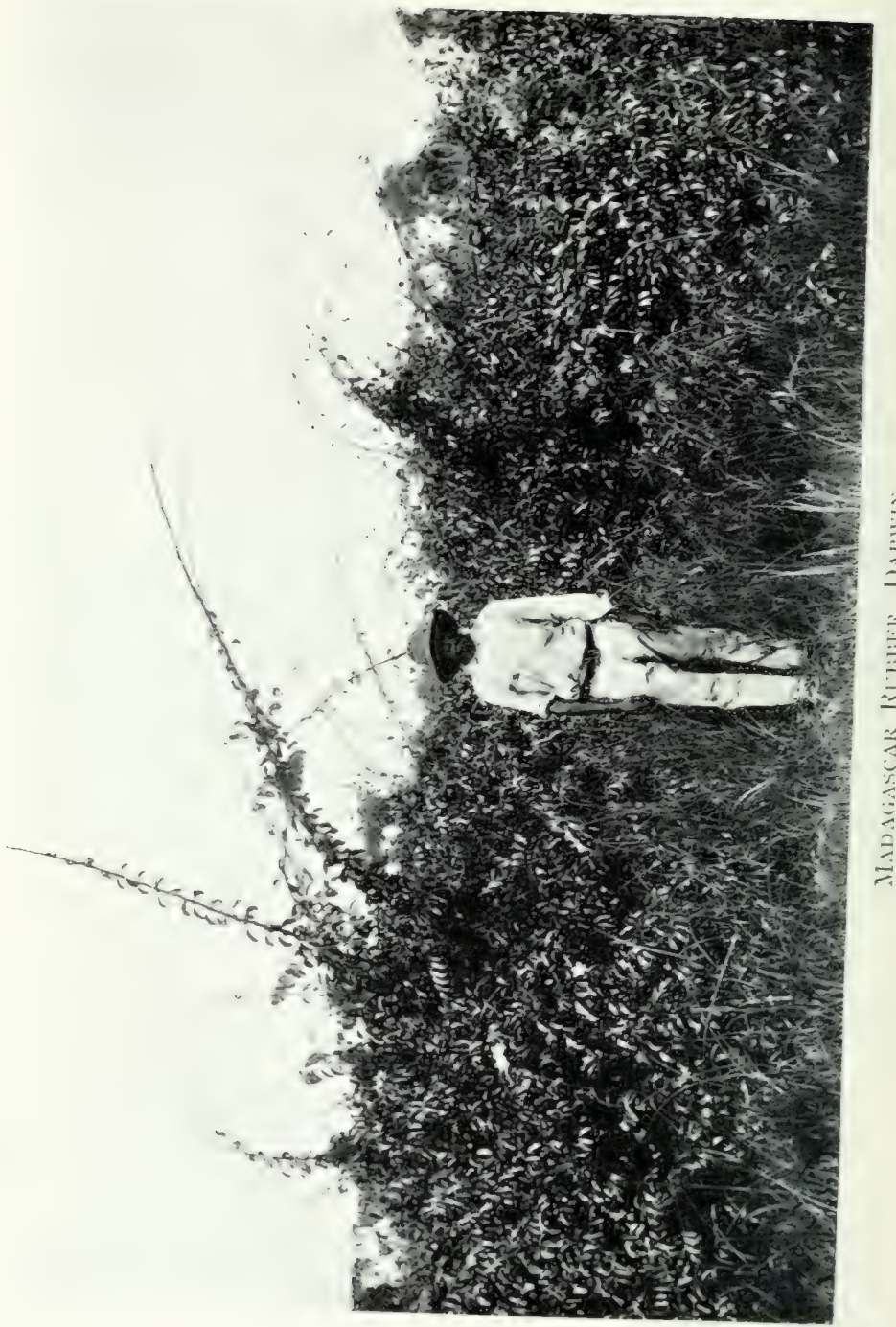




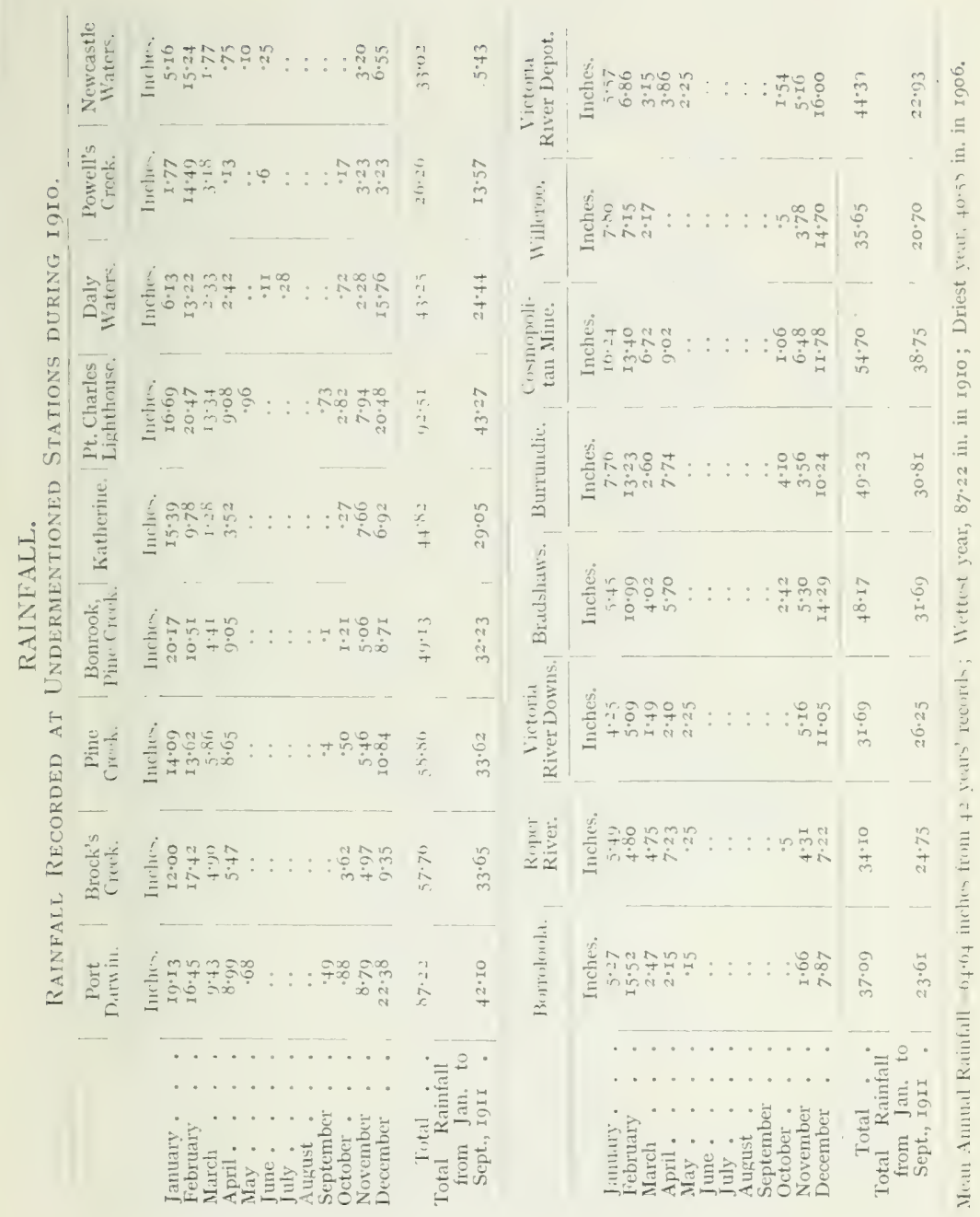




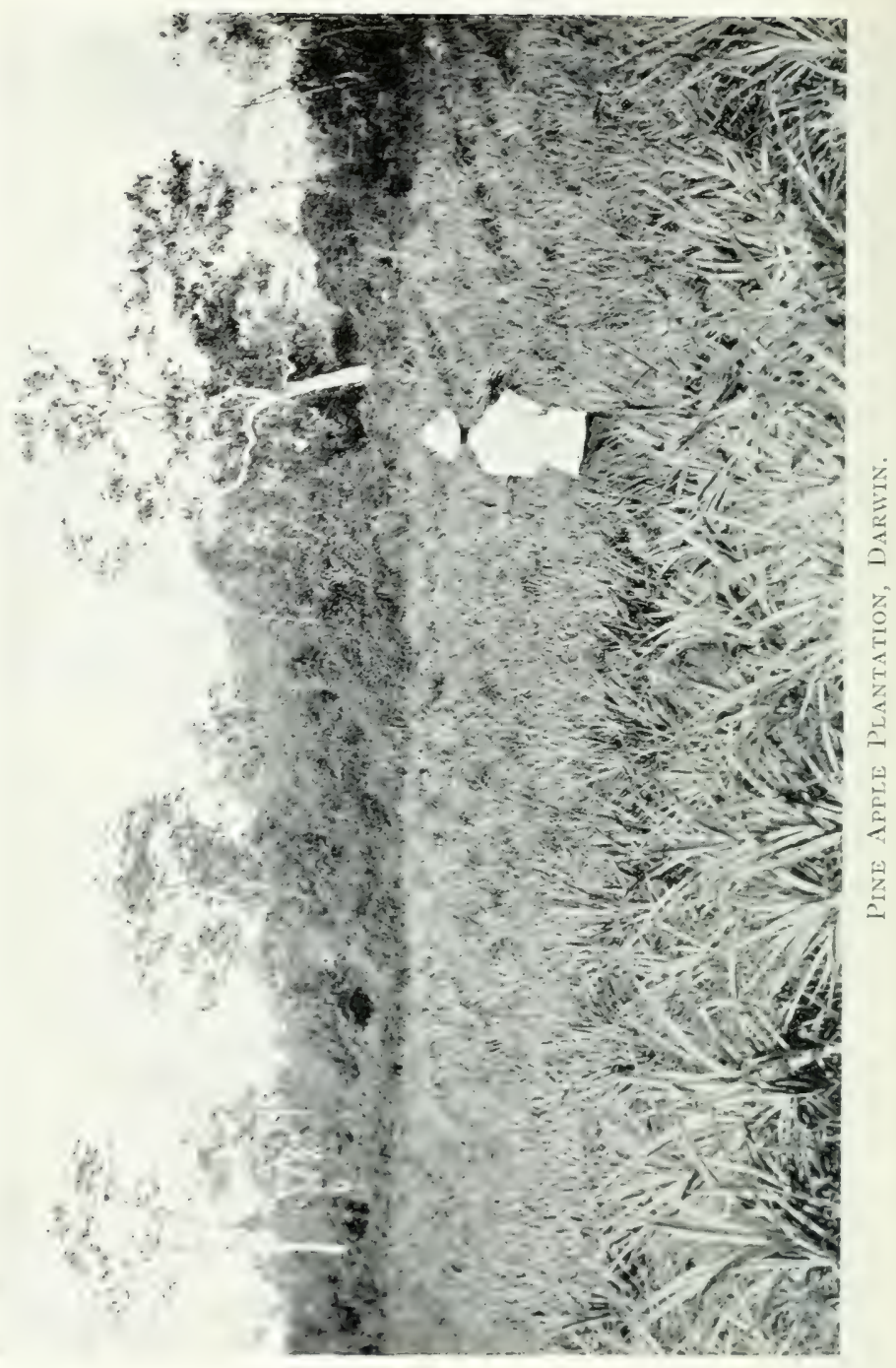




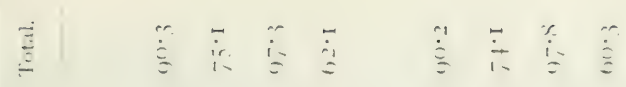

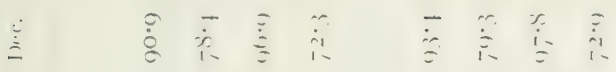

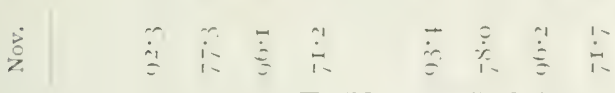

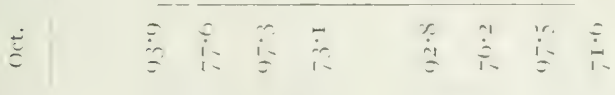

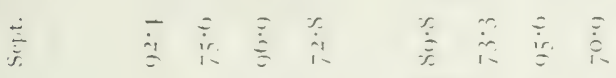

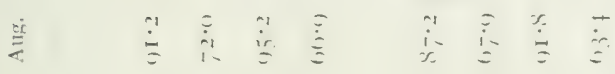

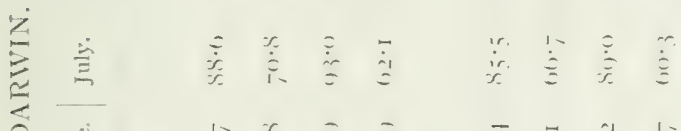

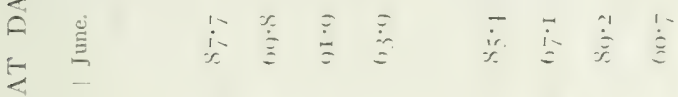

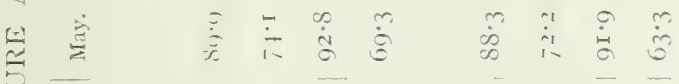

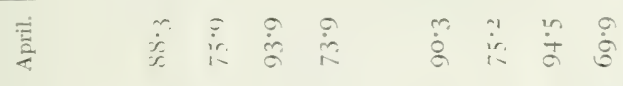

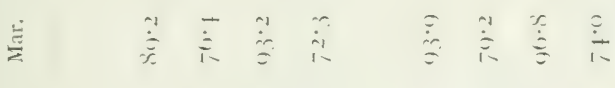

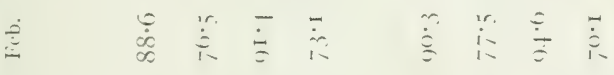

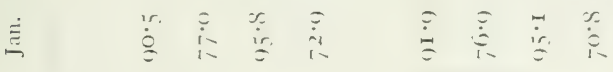

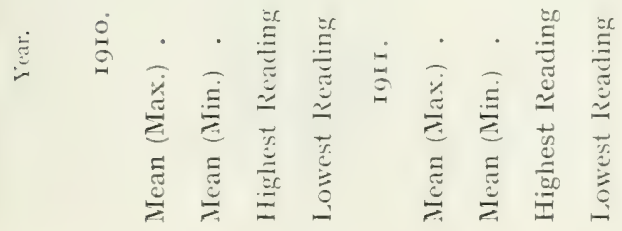




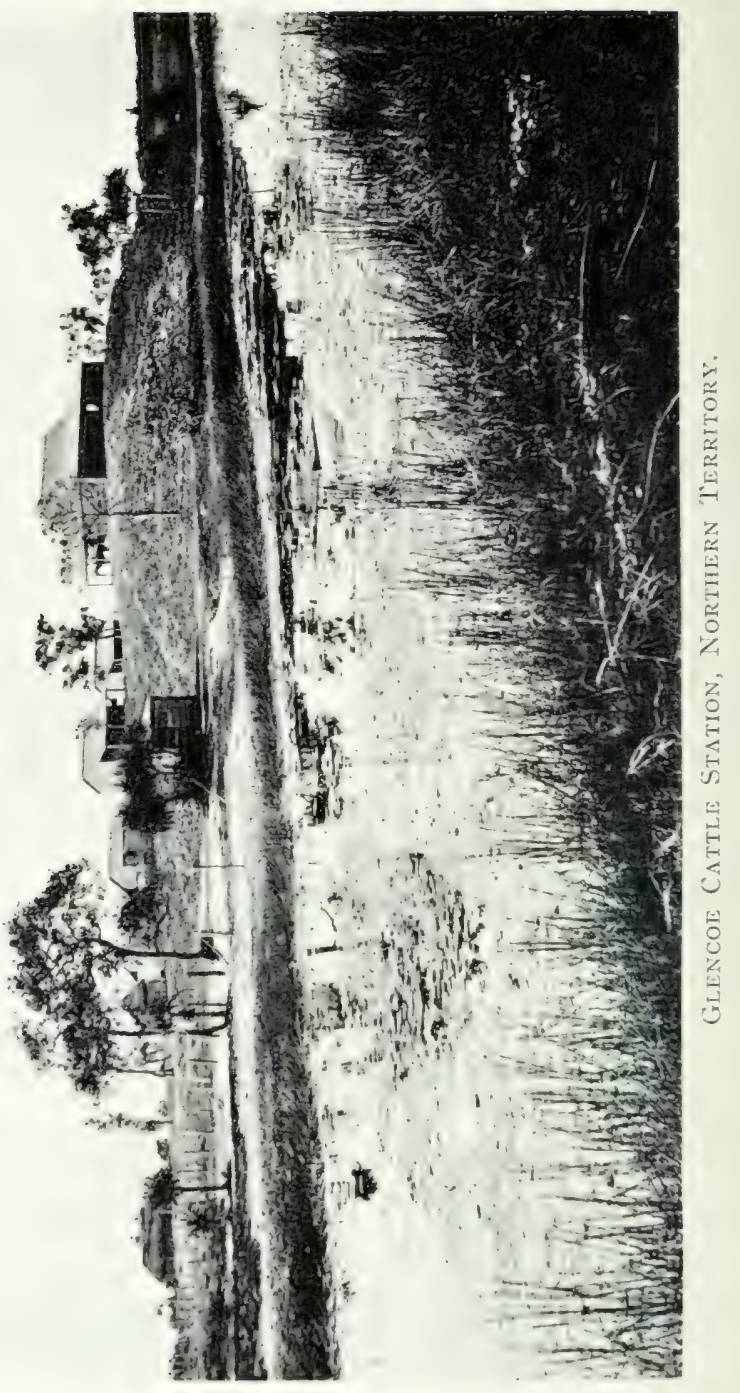




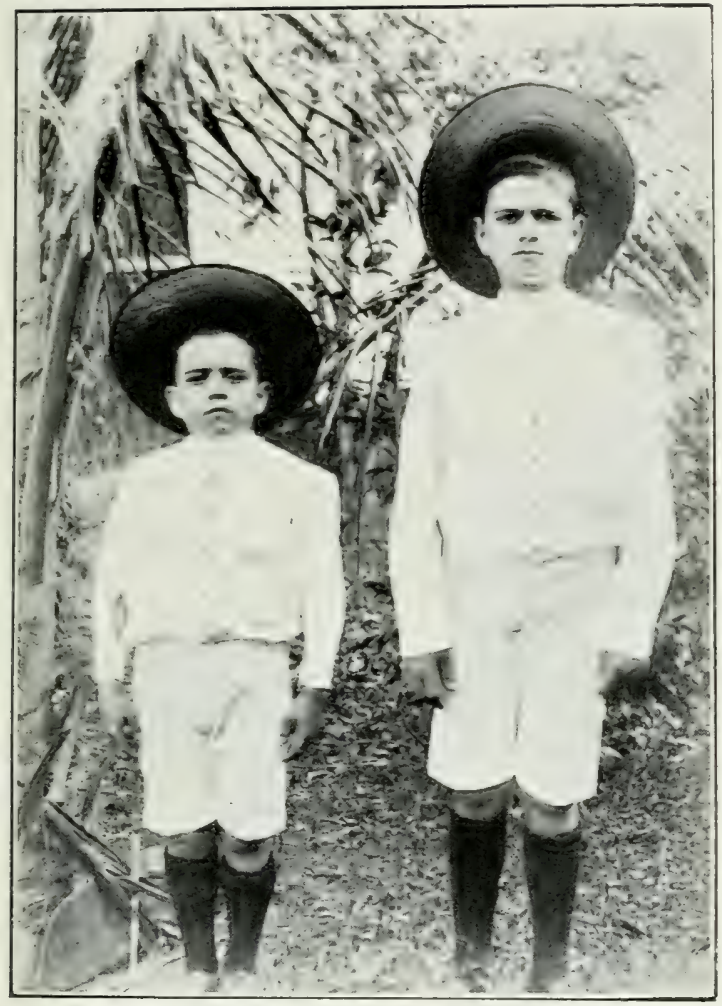

Third Gexeratiox (Mother's Side) Darwinians. 


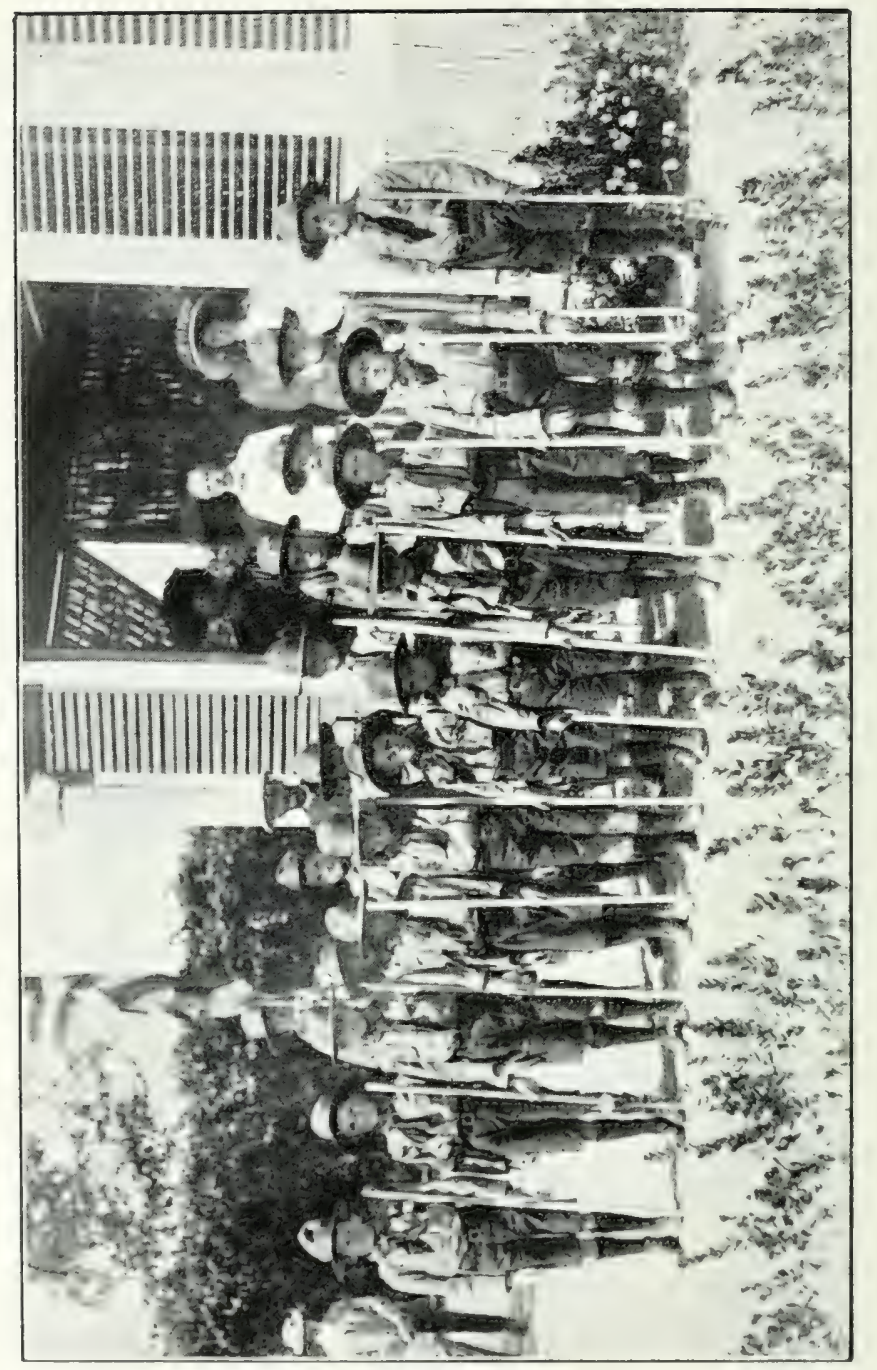




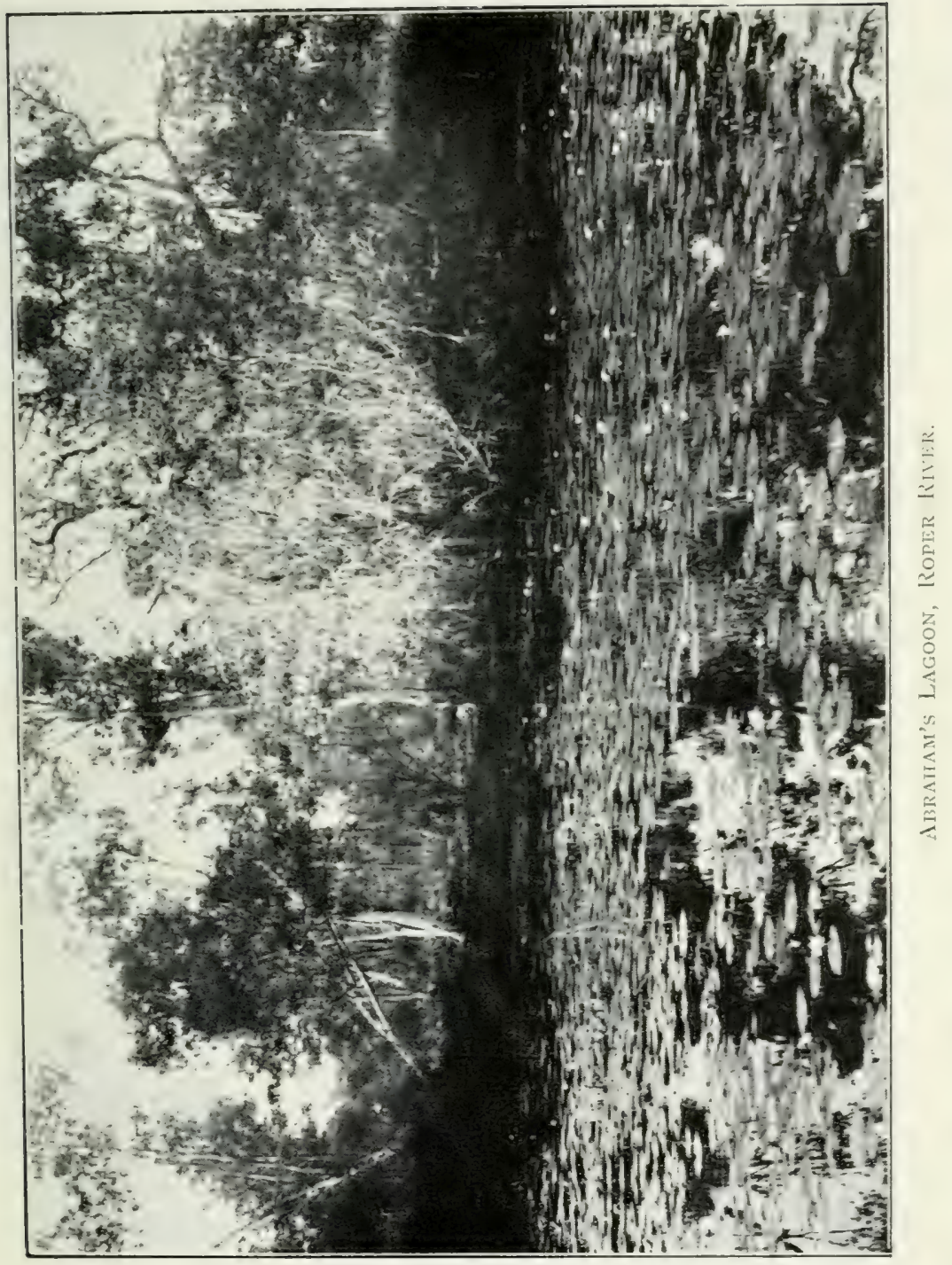




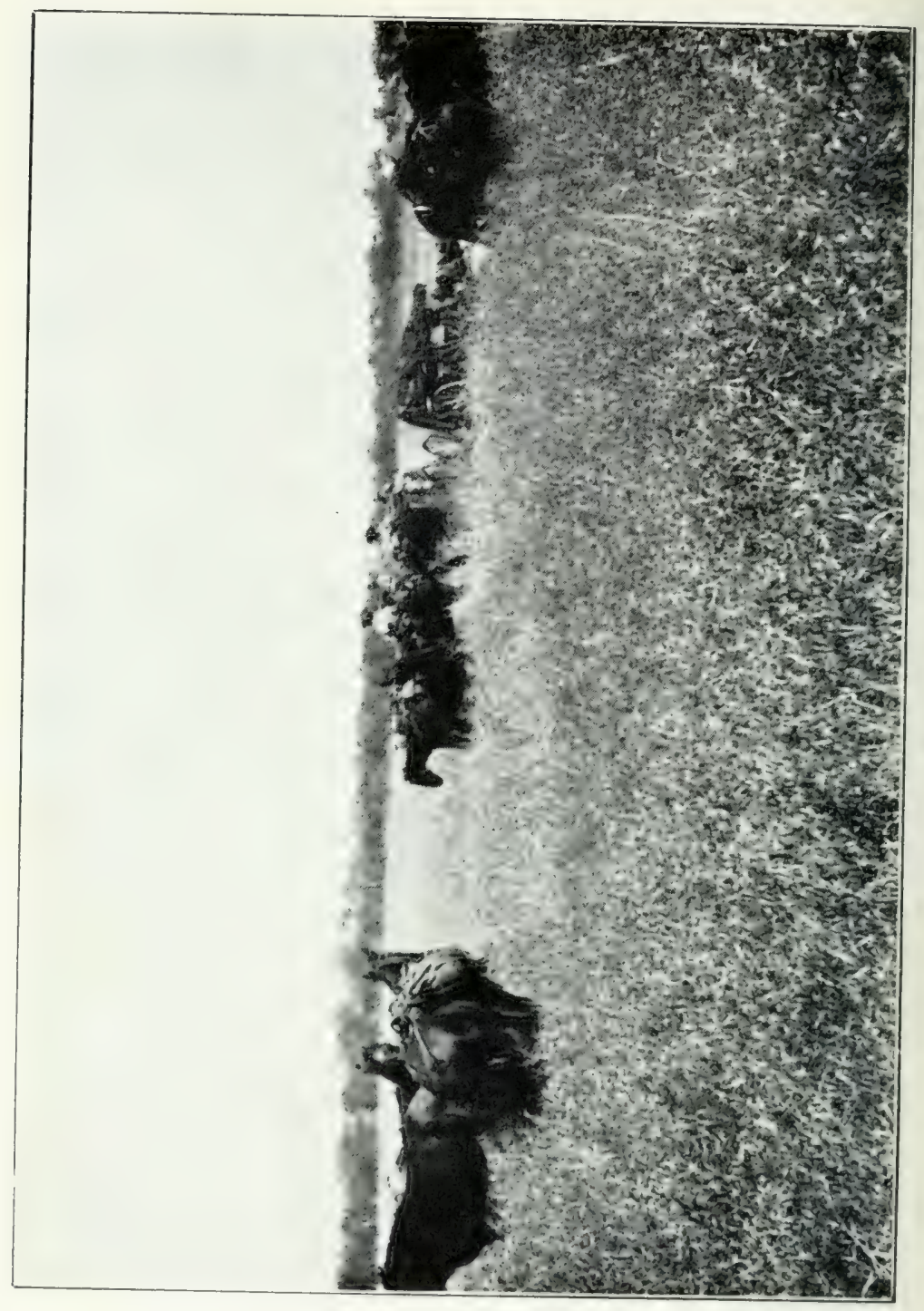




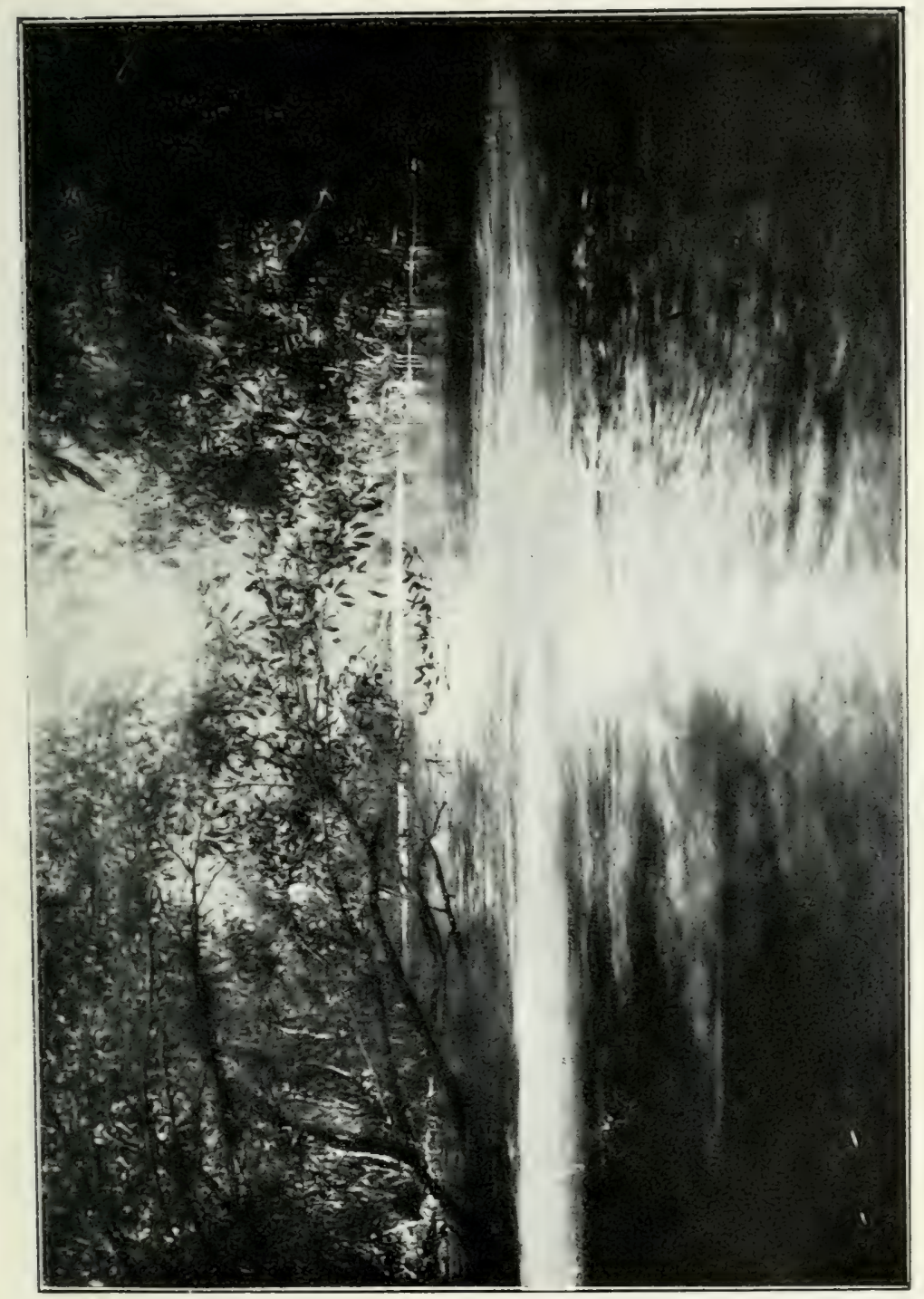




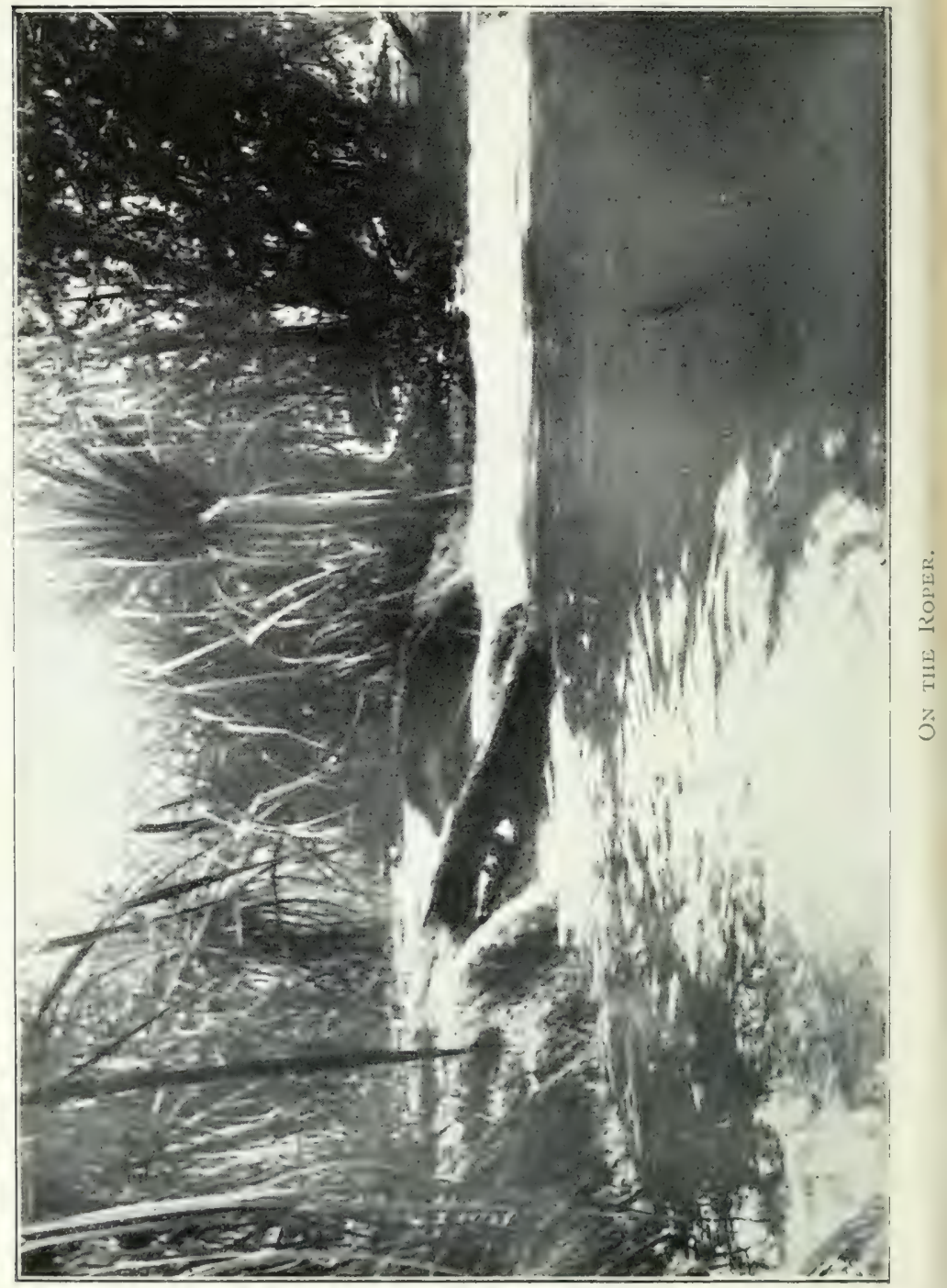






\section{PLEASE DO NOT REMOVE \\ CARDS OR SLIPS FROM THIS POCKET}

\section{UNIVERSITY OF TORONTO LIBRARY}

\section{H\&SS \\ A \\ 3957}




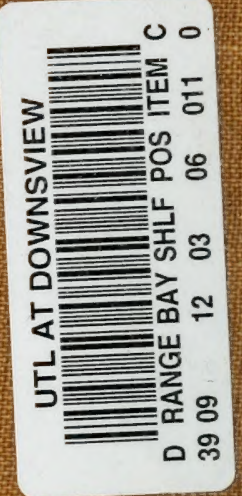

